\title{
REPERTORIUM KSIĄG WIZYTACJI KANONICZNYCH BISKUPÓW KUJAWSKO-POMORSKICH PRZECHOWYWANYCH W ARCHIWUM DIECEZJALNYM W PELPLINIE
}

\section{CZĘŚĆ II ${ }^{1}$}

\section{G 26}

\section{A. OPIS KSIĘGI}

[1. Sygn. akt.] G26.

[2. Tytuł oryg.] Archidiaconatus Pomeraniae sub auspiciis Illustrissimi Excellentissimi et Reverendissimi Domini Domini Constantini Feliciani de Szaniawy Szaniawski², episcopi Vladislaviensis et Pomeraniae, per Joannem Casimirum Iugowski ${ }^{3}$, archidiaconum Pomeraniae, visitatus Anno Domini 1710 et 1711.

[3. Daty krańc.] 1710-1711.

[4. Opis zewn.] Łac.-Pol. $2^{0}(36,0 \times 24,0 \mathrm{~cm}$.). Stron paginowanych cyframi rzymskimi XVI. Stron paginowanych cyframi arabskimi 425. Po stronie 275 znajduje się 10 kart niepaginowanych, gdzie zapisano sporządzony indeks alfabetyczny parafii. Od karty 275 , stawianych w nawiasach okrągłych, znajduje się dawna

* Ks. Witold Kujawski - dr hab. historii Kościoła, prof. UMK, Kierownik Zakładu Historii Kościoła - Starożytnej i Średniowiecznej, Wydział Teologiczny UMK w Toruniu.

${ }^{1}$ Pierwszą część niniejszego Repertorium opublikowano w tomie 84 Archiwów Bibliotek i Muzeów Kościelnych, s. 93-236 (przypis redakcji).

${ }^{2}$ Szaniawski Konstanty Felicjan, biskup włocławski w latach 1706-1720, później biskup krakowski.

${ }^{3}$ Jurgowski Jan Kazimierz, archidiakon pomorski, zm. w 1726 r. Biogram tego prałata zob. S. C h o d y ń s k i, Katalog prałatów i kanoników włocławskich, s. 346, 348-350 [rkps w Archiwum Diecezjalnym we Włocławku]. 
paginacja od 1 do 151. Ponieważ jest to jednak jedna księga, a nie dwie oprawione razem, nową paginacją zaznaczono te część księgi, gdzie umieszczono dekrety reformacyjne. Oprawa stara, w skórę tłoczoną. Na grzbiecie księgi napis: „Visitatio Szaniawski”. Stan zachowania oprawy i całej księgi dobry. Pismo staranne i jednej ręki. Karty puste: VI, XVI, 90d, 102-104, 130- z kartą następną nlb, 154, 186, 208-210, 243c, 275, 275v, 18(292), 34(308), 40(314), 66(340), 98(372), 114(388), $130(404)$.

[5. Uwagi] Była to wizytacja generalna, tak zewnętrzna, jak i wewnętrzna, ponieważ niekiedy zwracano także uwagę na sprawy związane z życiem wewnętrznym duchowieństwa.

W niniejszym repertorium nazwy parafii podawano w obecnym brzmieniu. Nazwy miejscowości natomiast, ponieważ wyliczano je bardzo dokładnie, podano w brzmieniu ówczesnym.

Przy wyliczaniu wsi podawano zazwyczaj, jakie ofiary z postaci mesznego $\mathrm{z}$ nich oddawano oraz najczęściej podawano także właściciela. Rozróżniano tu jednak pomiędzy dochodami, jakie były na rzecz utrzymania świątyni parafialnej, czyli dochodami parafii, a dochodami samego proboszcza.

W protokółach tej wizytacji podawano prawdopodobnie nie tylko wszystkie wioski, ale i przysiółki, czy pojedyncze osady, często były to osady młyńskie. Znacznie więcej niż w wizytacjach poprzednich. Wielu z nich nie da się zidentyfikować.

Gdy idzie o paramenty liturgiczne, zasadniczo ograniczano się do wyliczenia naczyń srebrnych.

Kiedy podawano ilość wiernych, chociaż nie we wszystkich protokółach, prawdopodobnie brano pod uwagę tych, którzy przystępowali już do sakramentu pokuty i Komunii świętej.

$\mathrm{Z}$ wielu protokółów, zwłaszcza tych ostatnich, trudno dowiedzieć się, czy był przy kościele kapłan i czy odbywały się nabożeństwa. Sporadycznie tez podawano ilość wiernych. Może niektóre te sprawy wyjdą w zarządzeniach powizytacyjnych, pomieszczonych $\mathrm{w}$ drugiej części księgi. Przy tych dekretach podawano niekiedy daty ich wystawienia. Może są to daty wizytacji. Jednak kolejność wizytacji dekanatów nie jest zgodna z kolejnością zapisów dekanatów wizytacyjnych. Znaczyłoby to, że dekrety, jeżeli nawet były wystawiane razem z wizytacją, to zapis w księdze zarządzeń wizytacyjnych, musiał być robiony osobno, na podstawie brudnopisu.

\section{B. ZAWARTOŚĆ KSIĘGI}

Na wewnętrznej stronie okładki napis: Szaniawski per Jugowski z wyjaśnieniem w języku niemieckim.

Karta tytułowa z tytułem podanym jak wyżej, s. I.

Herb biskupi Feliksa Konstantego Szaniawskiego i formy grzecznościowe, zapewne ułożone przez sekretarza tej wizytacji, Jana Lewińskiego ${ }^{4}$, s. II-IV.

\footnotetext{
${ }^{4}$ Jego podpis znajduje się na końcu strony IV.
} 
Pismo wizytatora Jana Kazimierza Jurgowskiego, archidiakona pomorskiego, adresowane do ordynariusza diecezji włocławskiej i-pomorskiej, Konstantego z Szaniawy Szaniawskiego, z osobistym podpisem Jurgowskiego, s. V.

Pismo wizytatora skierowane do duchowieństwa $\mathrm{i}$ wiernych archidiakonatu $\mathrm{z}$ racji mającej się rozpocząć wizytacji, s. VII-X.

Wykaz pytań, jakie będą stawiane proboszczom, dotyczące tak spraw ogólnych, stanu świątyni, duszpasterstwa, jak i osobistego zachowania się duszpasterzy, s. XI-XIV.

Przykłady formularzy pism, jakie w pomorskiej części są często zmuszeni wystawiać proboszczowie w kwestii przyjmowania sakramentu chrztu, czy małżeństwa w innych parafiach, a także pozwolenia na pogrzeby, s. XIV-XV.

\section{Wizytacja dekanatu berneńskiego [kościerzyńskiego]}

B e r n a [Kościerzyna $]^{5}$. Świątynia murowana, przed około sześćdziesięcioma laty wystawiona staraniem kartuzów, którzy są właścicielami wsi parafialnej Grabowo. Wspomniano, ze dawny drewniany kościół został spalony przez Szwedów i był pw. św. Wojciecha i św. Jerzego. Opis świątyni i jej wnętrza. Wykaz uposażenia.

Istniało bractwo Różańca świętego, posiadające dokumenty świadczące o specjalnym uposażeniu w postaci zapisanych sum na dobrach Stawiska i innych. Wykaz paramentów.

Dochody proboszcza. Wykaz miejscowości parafialnych, z których pobierał proboszcz meszne: Zamek w Kościerzynie, miasto Kościerzyna i wsie: Korne, Lubiana, Owśnice, Fiszerowa Huta, Szynheida, Kruszyna, Szymbark ze świątynia luterańską, gdzie nie było katolików, Czernin, Skorzewo, Bierznica, Wąglikowice z kaplicą we dworze, ale bez uposażenia i paramentów kościelnych, , Klincz Mały, Puc z Zalesiem i Dobrogoszczem, Sikorzyn z dwoma wioskami zwanymi Huty, Sarnowy. Paramenty. Wójtostwo Kościerzyna miało sześć łanów, ale nie oddawało mesznego. Miasto zaś Kościerzyna miało także wieś zwaną Miejska Huta, skąd także proboszcz nic nie otrzymywał. Rekownica, w której znajdował się kościół. Bendomino Wielkie i Bendomino Małe, dawniej należące do parafii Kościerzyna, obecnie należy do parafii Rekownica. Roczny dochód proboszcz pobiera także z Pierszczewka. W tej wsi znajdowała się karczma, którą proboszcz Andrzej Laurinowicz, aktem spisanym w aktach ławniczych w Kościerzynie, zamienił ze starostą kościerzyńskim. Folwark Prohal, dawniej należący do probostwa, obejmujący 14 lub 16 łanów, nadanych jeszcze przez Krzyżaków, został wydzierżawiony, za zgodą Konsystorza na lat trzy niejakiemu Piotrowi Kalina za 120 florenów rocznie.

Zabudowania parafialne oraz dla organisty i nauczyciela. Istniał przytułek, zwany szpitalem, z własnym uposażeniem tu wyliczony. Była przy nim kaplica drewniana, aktualnie znajdująca się $\mathrm{w}$ ruinie.

\footnotetext{
${ }^{5}$ Poniżej używa się zawsze nazwy Kościerzyna.
} 
Aktualnie parafią administrował Maciej Lipieński, posiadając wszelkie dokumenty, s. 1-7.

S t ę ż y c a. Kościół nowy, murowany, staraniem obecnego proboszcza, z jego funduszy i z ofiar wystawiony, Opis świątyni. Był przywilej odpustowy na św. Jana Chrzciciela i św. Katarzynę z 1700 r. Bractwo Różańcowe i Najświętszego Imienia Jezus. Uposażenie parafii, według dawnych wizytacji liczące 4 łany. Dokładny opis pól.

Wsie parafialne: Stężyca Szlachecka i Stężyca Królewska, Gostomie, Niesiołowice, Borucin, Mściszewice, Kamienica, Żeromino, Przewóz, Zgorzałe, Golubie, Czaple, Pierszczewko, Nowa Wieś, Huta Klukowa, Łosieniec, Huta Kamieniecka.

Zabudowania parafialne. Szkoła, w której mieszka organista, uczący zaledwie dwóch uczniów. Przytułek, bez własnego uposażenie, a w nim czterech podopiecznych, żyjących z jałmużny.

Proboszcz Jakub Franciszek Alshutt, od 1690 r., aktualnie dziekan mirachowski, k. 7-10.

G r a b o w o ${ }^{6}$. Dawniej kaplica pw. św. Anny, nie konsekrowana, służąca jedynie kartuzom, przed ośmioma laty zamieniona na świątynię parafialną. Opis wnętrza. Dzwonnica w wieży. Paramenta liturgiczne.

Uposażenie, jak to stwierdzały dokumenty, stanowiły cztery łany ziemi. Wsie parafialne: Grabowo, Kłobuczyno, Foshuta, Huta Grafowska, Jasiowi Huta, Sztofrowa Huta, Szpon, Lerckie, Ossenkop. Zabudowania parafialne zbudowane przez dziewięcioma laty w tzw. pruski mur. Organista i nauczyciel w jednej osobie miał swój domek. Parafią administrował Jan Schram, s. 10-12.

L i p u s z. Wieś królewska. Kościół drewniany pw. św. Michała. Jego opis. Paramenta liturgiczne.

Uposażenie proboszcza w cztery łany ziemi. Wsie paraf.: Lipusz, Kalisz, Puszkowy, Skwierawy, Gostomko, Ścibol, Żołna, Grzybowo, Wyrówna, Dziemiany, Trawice, Pelk - osada młyńska, Diwan, Śluza, Jabłuszek, Borowiec, Zdroje, Lorens. Zabudowania parafialne drewniane. Szkoła, w której mieszka nauczyciel i organista $\mathrm{w}$ jednej osobie ${ }^{7}$.

W i e 1 e. Wieś królewska. Kościół drewniany pw. św. Anny Opis świątyni. Paramenty liturgiczne. Bractwa dwa: Św. Józefa i św. Anny, posiadające przywileje nadane przez Stolicę Apostolską.

Uposażenie proboszcza $\mathrm{w}$ pięć łanów ziemi. Wsie parafialne, z których proboszcz pobierał meszne: Wiele, Karsin folwark i Karsin wieś, Górki, Przytarnia, Borsk, Dabrowa, Miedzo, Cisewie, Wojtal, Ossowo, Piechowice, Kliczkowy, Broda, Odry z kaplicą starą, Dziedzic miejscowy wynagradzał proboszcza, gdy tu

\footnotetext{
${ }^{6}$ Dawniej nosiło nazwę Grabowo Stare, obecnie Grabowo Kościerskie.

${ }^{7}$ Nie podano żadnej wiadomości o proboszczu.
} 
odprawiał, Plęsy, Wdzydze Kiszewskie. Zabudowania parafialne drewniane. Nie wymieniony z imienia i nazwiska aktualny proboszcz przeznaczył swój inwentarz następcy. Był dom dla nauczyciela i organisty, s. 14-16.

G o r ę c z y n. Wieś należącą do zakonników Kartuzów. Kościół murowany pw. Wszystkich Świętych. Opis świątyni. Paramenty liturgiczne.

Uposażenie proboszcza w cztery łany ziemi. Wsie płacące meszne: Goręczyn, Ostrzyce, Burcz, Rąty, Wojciechowi, Somonino, Sławkowy. Wsie płacące proboszczowi kolędę: Kartuzy, Grzybno, Czaple Nowe, Leśno Owile, Polisino, Assybudy, Okmuca, Kolano, Starkowa Huta, Kamela, Egiert, Nowa Wieś, Dypendal, Czarna Huta, Osenkop, Chilowa Huta, Kapelowa Huta, Opendorf. Plebania murowana. Dom dla nauczyciela, gdzie mieszkał organista ${ }^{8}$, s. 16-19.

K i e 1 p i n. Wieś należąca do zakonników Kartuzów. Kościół murowany pw. św. Michała Archanioła. Opis świątyni. Kościół miał na swoje utrzymanie dochód z pewnej łąki, która była w dzierżawie. Proboszcz dostał polecenie, aby łąkę tę odzyskał.

Uposażenie proboszcza stanowiły trzy łany. Nie było plebanii, ani domu dla organisty, s. 19.

C h m i e $1 \mathrm{n}$ o. Wieś zakonnic z Żukowa z kościołem parafialny, drewnianym pw. św. Piotra i Pawła,. Opis świątyni. Wyposażenie w Paramenty liturgiczne.

Uposażenie proboszcza składające się z czterech łanów ziemi, łąki i dom. Do parafii należały wsie, z których pobierał opłaty: Chmielno, Zawory, Remboszewo, Brodnica, Łądczyno, osada młyńska Łądczynek, Porostowo, Miechucino, Cieszenie, Rydyskowo, Pożyczkowo, Garcze, Prokowo, Kosz, czyli Burakowo, Smętowo, Lipowiec, osada młyńska Chmielnik, Łapalice, Lampa, a także wsie Brodnica Dolna, Huta Borostowska, , Huta Łączyńska, Huta Miechucińska.

Stan zabudowań parafialnych, nieco wymagających naprawy. Don szkoły wymaga pilnej naprawy. Mieszka w nim organista. Pobierał o między innymi wynagrodzenie. Przytułek dla ubogich. Proboszcz zapisał na ten przytułek, niedawno odbudowany, zapis dający 400 florenów.

Od lat 10 proboszczem był Mikołaj Kręcki, s. 19-22.

S i e r a k o w i c e. Wieś szlachecka Jerzego Bystram, Kościół drewniany, pw. św. Marcina. Opis świątyni i jej uposażenie. Paramenty liturgiczne. Uposażenia własnego nie było, jedynie ofiary i zapis na dobrach Jana Kętrzyńskiego, dające roczny dochód 40 florenów.

Proboszcz miał uposażenie czterech łanów i meszne z wsi parafialnych: Sdierakowice, Puzdrowo, TuchlinGowidlino, Lisniewo, Żalłakowo, Pałubie, Kamienica, Kamieńskie Młyny. Następujące wsie dawały jedynie kolędę: Mojsz, Huta Mściszewska, Smólnicy na Bukowie, Mrozy, Potoki, Huta Sierazowska, Huta Tu-

\footnotetext{
${ }^{8}$ Nie ma żadnej wzmianki o proboszczu.
} 
chlińska, Bigota, Smólnicy Gowidlińscy, Lenami ${ }^{9}$ za Gowidlinem, Kowale, Potęgowo, Pączewo, Kokiwin, Szopa, Huta Szopska, Huta nad Łąkami ${ }^{10}$. Zabudowania plebańskie w ruinie. W szkole mieszkał nauczyciel, który był też organistą.

Proboszczem był od roku Jan Bystram, s. 22-24.

S i a n o w o. Kościół tak zniszczony, że jedynie do odbudowy się nadający. Znajdował się jednak w niej obraz Matki Bożej łaskami słynący. Opis kościoła. Uposażenie kościoła i Paramenty liturgiczne.

Uposażenie proboszcza $\mathrm{w}$ jeden łan ziemi oraz łąki. Wsie parafialne oddające meszne: Sianowo, Stajszewo, Suszonka, Ostusino, Huta Sienowska, Pomieczne, Huta Pomieczyńska. Zabudowania plebańskie zniszczone. Dla nauczyciela, o którego domu nie wspomniano, było uposażenie od proboszcza i ofiary od parafian. Nie wymieniono nazwiska proboszcza, s. 25-26.

$\mathrm{S}$ t $\mathrm{r}$ z e p c z. Wieś rządowa w starostwie mirachowskim. Kościół drewniany p.w. św. Marii Magdaleny, Opis świątyni. Wyposażenie w paramenty liturgiczne.

Uposażenie proboszcza w cztery Łany ziemi oraz ogrody i dom i spora ziemi z których pobierał czynsz. Wsie z których proboszcz pobierał meszne: Strzepcz, Tłuczewo, Linia i folwark Linia, Niepoczołowice, Zakrzewo, Zępcze, Dargolewo, Pobłocie, Zmarzyno, Lepcie, Lewino, Bednarowo. Inne wsie oddawały jedynie kolędę, a mianowicie: Rosochy, Lewinko, Huta Lebińska, Pomieczyno, Huta Stara Mirachowska, Nowa Bądź Mirachowska, Bądcze, Mirachowo, Borek. Zabudowania plebańskie w tzw. pruski mur. Był dom dla nauczyciela, który był i organistą był dom dosyć wygodny, a wynagradzali go parafianie. Był też przytułek z własnym wyposażeniem. Prowizorem szpitala był niejaki Jan Dzięcielski z Lewina.

Proboszczem od roku był Stanisław Trzęskowski, s.26-28.

L u z i n o. Wieś należąca do zakonnic z Żukowa. Opis świątyni. Wyposażenie w paramenty liturgiczne.

Uposażenie proboszcza w cztery łany ziemi. Wsie parafialne oddające meszne. Lizin, Bartomino, Kębłowo, Wysieczyno, Strzebielino, Gosticzyno, Młyn Gostyczyński, Gowino Wielkie, Gowino Małe, Sopieszyno, Ustarbowo, Młyn Ustarbowski, Dąbrówka, Młyn Dabrówka, Cząstkowo, Malwino, Robakowi, Przytoczyno. Nie wspomniano o proboszczu, s. 29-30.

\section{Wizytacja dekanatu puckiego}

W e j h e r o w o. Miasto fundowane przed sześćdziesięcioma laty przez Jakuba Wejhera, obecnie w posiadaniu księcia Aleksandra. Świątynia fundowana razem z miastem. Nie było dokumentów erekcyjnych, ale podobno znajdowały się u reformatów, stąd, jeżeli oni je mają, należy z ich rąk je odebrać. Kościół para-

\footnotetext{
${ }^{9}$ Lenami, była to ludność osiadła, przeważnie dawni żołnierze.

${ }^{10} \mathrm{~W}$ niektórych tych wioskach był jeden tylko kolonista.
} 
fialny p.w. Świętej Trójcy, konsekrowany przez biskupa sufragana Piotra Mieszkowskiego ${ }^{11} \mathrm{w} 1645$ r., zbudowany został w tzw. pruski mur. Opis świątyni. Uposażenie świątyni stanowiły trzy domy, już zniszczone, ale witrykusi odbierają $\mathrm{z}$ nich pewien czynsz. Wyposażenie $\mathrm{w}$ paramenty liturgiczne.

Uposażenie proboszcza. Nie było ziemi, ale z zapisu z 22 VII 1653 r. był dochód zabezpieczony na dobrach Pętkowice i wsi Naniec,: Miejscowości parafialne płacące meszne: miasto Wejherowo i folwark, Schmechau, Pretkowice folwark, młyn Śmiechowo, zamek Rucewo, karczma Lantreyter. Podano, że katolików było około 600 .

Zabudowania plebańskie dobre, w pruski mur nowo wystawione, Podobny dom był dka wikariusza. Organista i zakrystianim mieli swoje domy i uposażenie od parafian. Przytułek, ale wymagający naprawy. Było czterech podopiecznych, a powinno być sześciu, jak to wynikało z uposażenia zapisanego przez Katarzynę Leszczyńską.

Proboszcz Franciszek Walenty Ruthensis ${ }^{12}$, s. 31-34.

G ó r a. Wieś królewska. Kościół drewniany p.w. św. Macieja Apostoła. Opis świątyni. Paramenty liturgiczne.

Uposażenie proboszcza w cztery łany ziemi oraz łąki i prawo połowu ryb w pobliskim jeziorze. Wsie parafialne, z których pobierano meszne: Góra, Kniejo, Warzkowo, Młyn Waszkowo, Młyn Gostyczyński, Bolszewo, Młyn Góra, nowa karczma Janowskiego, Rybno, repkapinko, Żelewo, Grabowino, Kniejo. Zabudowania plebańskie złe i stare. Budynek szkolny zły i nie nadający się do naprawy, ale mieszkał i nim nauczyciel uczący dzieci w liczbie pięciu.

Parafią administrował proboszcz z Wejherowa, s. 34-36.

R e d a. Wieś królewska. Kościół drewniany, p. w. św. Katarzyny. Opis świątyni. Do uposażenia parafii należały dwie pasieki u Michała Płockiego, i trzy pasieki u Andrzeja Graba. Wyposażenie w paramenty liturgiczne.

Uposażenie proboszcza w cztery łany ziemi oraz meszne z wsi parafialnych: Reda, Ciechocino, Rekowo, Gniewowo, Młyn Gniewowski, Łężyce, Zagorze, Młyn Zamorski, Zbychowo, Pieleszewo, Wyspowo, Szmolta. Katolików, zdaje się tych do sakramentów wielkanocnych zobowiązanych, było około 300. Dom parafialny dosyć dobry, jednak proboszcz tam nie mieszkał, a że miał prawo propinacji, w zabudowaniu tym była karczma.

Parafią administrował proboszcz z Rumi, s. 36-38.

R u m i a. Wieś opata oliwskiego. Prezbiterium kościoła murowane, nawa zaś z pruskiego muru. Wezwanie świątyni św., Mikołaja i Świętego Krzyża. Opis wyposażenia w paramenty liturgiczne. Własność parafii stanowiły dwa domy oraz dwie krowy.

Uposażenie proboszcza stanowiły cztery łany ziemi. Wieśniacy z Rumii byli

\footnotetext{
${ }^{11}$ Biogram tego biskupa zob. C h o d y ń s k i, Biskupi sufragani, s. 64-66.

${ }^{12}$ Lekcja nazwiska niepewna.
} 
zobowiązani dawać rocznie wóz drewna, albo gęś. Ci zaś co są mieszkańcami u wieśniaków, mają dawać dwa wozy drewna lub gęś. Na święta Wielkanocy każdy z kmieci ma dać 15 jaj. Wieś Rumia płaci meszne, zaś wieś Syncrof płaci sześć florenów. Katolików było 146, zaś luteran 20. Zabudowania plebańskie, dawniej okazałe, teraz zniszczone. Do naprawy byli zobowiązani mieszkańcy Rumii. Była szkoła, zamieszkała przez organistę, który też uczył dzieci i był wynagradzany przez mieszkańców.

Parafią administrował Jan Antoni Cratz, s. 38-40.

O k s y w i e. Wieś należąca do zakonnic z Żukowa. Kościół p.w. św. Michała Archanioła, w pruski mur wystawiony. Opis świątyni. Wykaz paramentów liturgicznych,

Uposażenie proboszcza stanowiły trzy łany, trzy domu z których miał czynsz oraz meszne w wsi: Oksywie, Obluza, Pogorze, Pierwoszyno, Koszakowo, Dębogorze, Gdynia, Radłowo Wysokie, Muchlinko, Rewa, Grabowko, folwark Mostowo, Bitomono. Wiernych katolików, zdaje się zobowiązanych do sakramentów wielkanocnych było około 700. Zabudowania plebańskie dobre. Była szkoła. Spis inwentarza parafialnego po śmierci proboszcza Tomasza Jendrowskiego, dosyć dokładnie sporządzony.

Nie ma wiadomości o ewentualnym nowym proboszczu, s. 42-44.

C h y 1 o n i a. Wieś królewska, należąca obecnie do księcia Aleksandra. Świątynia z pruskiego muru, pw. św. Mikołaja. Opis świątyni. Parafia posiadała dwa domy. ale niestety dzierżawcy nic nie płacili czynszu.

Uposażenie proboszcza stanowiły dwa łany ziemi w meszne z następujących wsi: Chylonia, Cisowo, Chwarzyn. Wiernych około 20 osób. Dom plebański wymagał naprawy. Nie było szkoły, ale było uposażenie.

Parafią administrował proboszcz z Oksywia Piotr Andrzej Schlesiger, s. 44-45.

P u c k. Miasto królewskie. Kościół murowany pw. św. Piotra i Pawła Apostołów. Opis świątyni. Uposażenie stanowiły dwa domy z czterema mieszkaniami, Dwa zajmowali kantor i organista, a z dwóch był czynsz. Ponadto był czynsz z wynajmowanego ogrodu oraz pewne zapisy, z których procent szedł na utrzymanie kościoła, czym zajmowali się witrykusi. Ponadto były osobne zapisy na kaplice przy świątyni parafialnej, fundowane przez Mateusza Judyckiego ${ }^{13}$, archidiakona pomorskiego i Jakuba Wejhera, wojewodę malborskiego. Wykaz paramentów liturgicznych.

Uposażenie proboszcza stanowiły cztery łany ziemi oraz meszne płacone z następujących miejscowości. Miasto Puck i wsie: Błądzikowo, Osłonino, Zelestrowo (Zelistrzewo), Smolna, Płochowo, Mrzeżyno, Folwark Celbowski, Folwark Mrzeżyński, Brudzewo, Połczyno, Folwark Połczyński, Folwark Rucewski, Sławutowo, Rucewo. Zabudowania plebańskie w dobrym stanie. Do ich utrzymania należytego zobowiązane było miasto z nakazu królewskiego z 20 V 1698 r. Był

${ }^{13}$ Biogram tego prałata zob. C h o d y ń s k i, Katalog, s. 342-346,347. 
dom dla rektora szkoły, uczącego podstaw gramatyki. Organista, nauczyciel i kantor pobierali uposażenie także z tytułu brania udziału w nabożeństwach w kaplicy Judyckich i Wejherów.

Dawniej był przytułek i prepozytura św. Jerzego, poza miastem. Ten kościółek i szpital uległy zniszczeniu z powodu wojny. Na tym miejscu urządzono cmentarz, na którym chowają się akatolicy. Pewien dochód ma z tego parafia i proboszcz. Był też i szpital, zwyczajem innych miast urządzony, znajdujący się przy bramie gdańskiej, a w nim 5 podopiecznych, którzy utrzymywali się z jałmużny i z dochodów płynących z procentów od zapisanych sum, s. 45-50.

S w a r z e w o. Wieś królewska,. Kościół pw. Narodzenia Najświętszej Marii Panny. Opis świątyni częściowo drewnianej, częściowo murowanej. Na uposażenie kościoła był domek, z którego czynsz brali witrykusi. Wykaz paramentów liturgicznych.

Uposażenie proboszcza stanowiły dwa łany ziemi i meszne z wsi: Swarzewo, Gnieżdżewo, Wielka Wieś (Grossendorf). Ponadto należeli rybacy z wsi: Chałupnica (Chałupy), Kuszfeldt, Nowa Wieś, Jastarnia Pucka, Jastarnia Gdańska czyli Helska. Opis zabudowań plebańskich, ale nie podano imienia proboszcza. Była szkoła, w której mieszkał organista spełniający role nauczyciela także, s. 50-53.

$Ł$ e b c z. Wieś królewska. Świątynia murowana pw. św. Marcina i jej opis. Paramenta liturgiczne.

Uposażenie proboszcza stanowiły cztery łany ziemi z przywileju królewskiego z 1598 r. oraz prawo połowu ryb w morzu. Meszne pobierał proboszcz z wsi Bełcz i Chłapowo. W zabudowaniach plebańskich mieszkał dzierżawca [widać proboszcza nie było, bo i o nim nie ma wzmianki], s. 53-54.

S t r z e 1 n o. Wieś królewska z kościołem drewnianym, pw. św. Marii Magdaleny Opis świątyni i jej uposażenia, z którego praktyczni dochodu żadnego nie było. Paramenty liturgiczne.

Uposażenie proboszcza w cztery łany ziemi i meszne z wsi: Strzelno, Mieroszyno, Tupadły, Ostrowo, osada młyńska Czarnowieńska, Leśniewo, Poczernino, osada Holendrów, Dwór Ernesta Męskiego w Karwi, Cetniewo, należące do biskupa sufragana włocławskiego, Karwia Mała. Zabudowania plebańskie w stanie złym, zamieszkałe przez dzierżawcę uposażenia proboszczowskiego [ widać stąd, że na miejscu proboszcza nie było], s. 55-57.

M e c h o w a. Wieś opata oliwskiego, ze świątynią pw. św. Mikołaja, stawianą w pruski mur. Opis świątyni i paramentów liturgicznych.

Uposażenie proboszcza w cztery łany, lecz większa ich część to lasy, zarośla i bagna. Dwie łąki zwane: Starałąka i Aszembruk. Zabudowania plebańskie dosyć dobre. W szkole mieszkał organista.

Proboszczem był Baltazar Marquart, s. 57-58.

$\mathrm{S}$ t a r z y n o. Wieś opata oliwskiego. Kościół murowany wystawiony przez 
opata Aleksandra Kęsowskiego, pw. św. Michała Archanioła i św. Jana Chrzciciela. Opis kościoła. Kościół sam utrzymywał się z ofiar składanych po kazaniu. Była też jedna krowa, którą miał proboszcz. Paramenta liturgiczne.

Uposażenie proboszcza stanowiły trzy łany ziemi i meszne z następujących wsi: Pelchowo, Parszkowo, Kłaniano, Radoszewo, Starzyno, Warblino, Dolotowo, Piaśnica. Zabudowania plebańskie w ruinie. Także szkoła była opuszczona.

Parafią opiekował się proboszcz z Mechowej, s. 59-61.

Ż a r n o w i e c. Wieś należała do benedyktynek, które tu miały klasztor, zreformowany przez klasztor z Chełmna. Świątynia parafialna, murowana i ładna, pw. Zwiastowania Najświętszej Marii Panny. Opis kościoła.

Przy kościele tym rezydowało dwóch kapłanów, a mianowicie spowiednik Michał Przyburczewski i kaznodzieja Paweł Kawecki. Trzeci zaś, to Jan Górski, zarządca parafii, który niedawno zaginął (prawdopodobnie zmarł) i nie pozostawił żadnych informacji. Te można było otrzymać częściowo z relacji innych osób, częściowo z zapisów księgi metryk prowadzonej przez księdza Stanisława Borkiewicza. Uposażenie proboszcza składało się wyłącznie z mesznego płaconego ze wsi: Sławoszyno, Odargowo, Lipkowo, Kartoszyno, Nadole, Wierzchucino, Sobieńcze, Karlikowo, Świecino, Warzywo, Żarnowiec, Lubocino, Tułowo, Opalno, Kołkowo, Lentowice i Krokowo należące do Krakowskiego.

W T u ł o w i e, wsi Czapskiego, podkomorzego pomorskiego, znajdowała się świątynia opuszczona, z dzwonnicą i dwoma dzwonami, odebrana przez bpa Madalińskiego innowiercom. Nie miała żadnego uposażenia. Oddana pod opiekę proboszczowi z Żarnowca, s. 61-64.

\section{Wizytacja dekanatu bytowskiego}

B r u s y. Wieś królewska. Kościół niedawno odbudowany, cały drewniany, pw. Wszystkich Świętych. Opis stanu i wyposażenia świątyni. Przy tym kościele znajdowało się bractwo Skaplerza Świętego, posiadające dokumenty jego zaprowadzenia. Kościół utrzymywał się z ofiar składanych na tacę, z ofiar przy pogrzebach oraz był zapis jednego z poprzednich proboszczów, zabezpieczony da dobrach sołtysa Michała Roszk. Wykaz paramentów liturgicznych.

Na uposażenie proboszcza były cztery łany ziemi oraz łąki, z których zbierano pięć wozów siana. Meszne zaś pobierano z wsi: Brusy, Kossobudy, Czyczkowy, Łubnie, Zalesie, Męcikał, Turowiecki, Dąbrowski, Okręglicki, Pokrzywiński, osada młyńska Czernica, Drewicz, Rolnik, Żabno, Czarnowo, Czapiewice, Główczewice, Glisno, Chełmy Wielkie, Chełmy Małe. Zabudowania plebańskie nowe i wykaz inwentarza. Była szkoła, a uczył organista.

Proboszcz Szymon Koliński. Wiernych z parafii Brusy i filii Łeśno było 487 osób, s. 65-67.

L e ś n o. Wieś królewska. Kościół filialny parafii Brusy, pw. Świętego Krzyża, tak zniszczony, że nie naprawy, ale odbudowy wymaga. Opis stanu świątyni. 
Uposażenie kościoła stanowiły ofiary oraz domek w Leśnie i drugi we wsi Prądzanka, z czego był pewien czynsz. Paramenta liturgiczne.

Uposażenie proboszcza stanowiły cztery łany ziemi oraz meszne ze wsi: Leśno, Orlik, Wysoka, Raduń, Trzebuń, Skoszewo, Kaszuba, Parzyn, Arszyn, Prądzanka, Kruszyn, Laska, Widno, Winkidorf, Pelplin. Zabudowania plebańskie zaniedbane. Szkoła w stanie zaniedbanym, a nauczyciel był wynagradzany przez parafian, s. 68-70.

S u 1 ę c z y n o. Wieś dziedziczna Heidensteinów, z kościołem drewnianym, pw. Świętej Trójcy. Opis świątyni. Dokument erekcji, znajdujący się u Heidensteinów, który jest też zapisany w aktach skarszewskich pod 1645 r. Zaś dokument fundacyjny i zapis uposażenia w ziemie z 1616 r., znajdował się w aktach zamku kościerzyńskiego. Spis paramentów liturgicznych. Znajdowało się bractwo, tu nie nazwane ${ }^{14}$, ale miało uposażenie w łan ziemi..

Uposażenie proboszcza stanowiły cztery łany ziemi oraz prawo połowu ryb zimą i latem w jeziorze. Ponadto proboszcz otrzymywał od fundatora specjalne roczne wynagrodzenie pieniężne. Meszne natomiast pobierał z wsi: Sulęcin, Węsory, Zdunowie, Żakowo, Podjazy, Kistowo, Bigos, Bork, Bukowa Góra. Zabudowania plebańskie były, ale niezbyt wygodne. Dla domowników proboszcza, czy rodziny, był osobny domek. Szkoła w złym stanie, a organista, czyli nauczyciel, brał wynagrodzenie z pałacu kolatora oraz od parafian.

Proboszczem był Marcin Żeromski, s. 70-72.

P a r c h o w o. Wieś królewska z kościołem pw. w. Mikołaja. Opis świątyni. Wykaz paramentów liturgicznych.

Uposażenie proboszcza stanowiły cztery łany ziemi i meszne ze wsi: Siliczno, Nakla, Goliczewo, Jamno, Bukówka, Chodnica, Grabowo, Kłodno, Kominy oraz osady Młyn Parchowski i Młyn Jamno, Parchowo, folwarki Nowy Dwór i Wydartowo. Zabudowania plebańskie dosyć dobre. W szkole mieszkał organista, pobierający wynagrodzenie od proboszcza i od parafian.

Proboszczem był Wojciech Prądzyński. s. 72-74.

$\mathrm{N}$ i e z a b r z y s z e w o ${ }^{15}$. Wieś w starostwie bytowskim, ze świątynią wystawioną w tzw. pruski mur, pw. św. Mikołaja i jej opis. Na uposażenie parafii szedł czynsz z małego domku oraz z łąki, a ponadto pewną składkę dawali mieszkańcy parafii. Paramenty liturgiczne skromne.

Uposażenie proboszcza w cztery łany ziemi i meszne ze wsi: Niezabyszewo, Rekowo i Sierzno. Plebania z ruinie, inne zabudowania gospodarcze dobre. Był dom szkoły i nauczyciel wynagradzany był z zamku [bytomskiego] i przez parafian.

Nie wspomniano o tym, kto był proboszczem, s. 74-76.

\footnotetext{
${ }^{14} \mathrm{Z}$ dawniejszych wizytacji widać, że było to bractwo różańcowe.

${ }^{15}$ Wówczas pisano „Niezabyszewo”.
} 
B y t ó w. Miasto i siedziba starostwa bytomskiego, gdzie było dużo luteran. Był tam kościół murowany, przypominający bazylikę, pw. św. Katarzyny, który przed jedenastoma laty spłonął. Zbudowano mały domek, w którym odprawiano w jedną niedzielę, a w drugą odprawiano w Niezabyszewie. Na uposażenie kościoła były dwa łany ziemi, z których czynsz pobierali witrykusi. Ponadto był czynsz z należących do kościoła łąk i ogrodów. Paramenty liturgiczne skromne.

Uposażenie proboszcza stanowiły cztery łany ziemi, posiadłość zwana Workland, jakaś łąka oraz opłata pobierana z miasta. Następujące miejscowości oddawały meszne: Gostkowo, Gostkowo Małe, Ząbinowice, Udorpie, Mędrzykowice, Dąbie, Osiek, Niedarzyno, Grzmiąca, Pomisko Małe, Lipusko, Domu parafialnego nie było. Szkoły nie było. Nauczyciel ma na utrzymanie dwa łany ziemi i pewien zapis, dochody z czego wypłacali mu witrykusi.

Nie podano imienia proboszcza, s. 76-78.

T u c h o m i e ${ }^{16}$. Wieś w starostwie bytowskim, której mieszkańcy byli głównie luteranami i mieli tam swojego ministra i swój zbór. Przed sześcioma, laty staraniem i kosztem Wawrzyńca Ryndwelskiego, proboszcza z Borzyszkowa i Tuchomia, kanonika kamienieckiego, wystawiono nową świątynię, konsekrowaną przez biskupa Załuskiego ${ }^{17}$. Jej opis. Na uposażenie kościoła stanowiła ziemia, zwana Kat, z czego był roczny czynsz. Aktualnie ta posiadłość była w ręku proboszcza, który nic nie płacił. Paramenta liturgiczne skromne.

$\mathrm{Na}$ uposażenie proboszcza były cztery łany ziemi z łąkami oraz meszne z wsi: Tuchomie Wielkie, Tuchomie Małe, Tągamie, Ciemno, Trzebiałkowo, Modrzewo, Piaszno. Plebania w ruinie, inne zabudowania gospodarcze dobre. Budynek szkolny w dużej ruinie. Nauczyciel opłacany przez parafian.

Proboszczem był Wawrzyniec Ryndwelski, jednocześnie proboszcz w Borzyszkowie, s. 78-79.

B o r z y t u c ho m. Wieś w starostwie bytowskim. Zamieszkiwało w niej wielu luteran, którzy mieli tu swój zbór i ministra. Była także świątynia katolicka wystawiona w tzw. pruski mur, pw. św. Jerzego ${ }^{18}$. Opis świątyni. Było pewne uposażenie dla kościoła, okołó pół łanu ziemi, którą od dawna trzymał karczmarz, ale nic nie płacił. Były jeszcze cztery parcele, dające pewien czynsz oraz ogród, z którego nic nie płacono. Paramenta liturgiczne skromne.

Uposażenie proboszcza stanowiły cztery łany ziemi oraz kmieć we wsi Kotkowo, siedzącego na dwóch łanach ziemi. Kotkowo, obecnie włączone jest do parafii Borzytuchom. Dawało to pewien dochód. Ponadto meszne z wsi: Borzetuchomie, Mosterzyno, Stryszewo, Krosniewo. Kotkowo. Zabudowania plebańskie dobre. Dla nauczyciela, którego aktualnie nie było, był domek z ogrodem . Nauczyciela opłacał proboszcz, s. 79-80.

${ }^{16}$ Wówczas pisano „Tuchom”.

${ }^{17}$ Prawdopodobnie był to Andrzej Chryzostom Załuski, administrator diecezji sambijskiej zob. P. N i t e c k i, Biskupi Kościoła w Polsce, k. 505.

${ }^{18}$ Dawniej podawano wezwanie św. Piotra i Pawła. 
K o t k o w o - kaplica. Wieś w starostwie bytowskim. Kaplica drewniana, ale nie podano jakiego wezwania. Uposażenie kaplicy stanowił ogród, z którego płacono czynsz. Domu dla proboszcza i nauczyciele nie było.

Kaplicą tą i parafią w Borzytuchomiu opiekował się proboszcz Wojciech Kazimierz Melcher, zarządca parafią Ugoszcz i Studzienica, s.81.

U g o s z c z. Wieś w starostwie bytomskim. Znajdował się tu zniszczony już bardzo kościół drewniany, pw. św. Marii Magdaleny. Opis tej świątyni. Na uposażenie świątyni był pewien fundusz z domkiem i ogrodem wielkości około pół łana, oraz drugi ogród, zwany Chmielnik, z czego pobierali witrykusi czynsz. Paramenta liturgiczne.

Proboszcz miał na uposażenie cztery łany ziemi z łąkami, domek z ogrodem, z czego pobieral czynsz oraz meszne ze wsi: Ugoszcz, Czarna Dąbrowa, Połczno, Ostowa Dąbrowa, opuszczona osada Zelewe, Saminy, Przywóz, Prądzanka, Studzience, Złączno. Dom plebański drewniany, z ogrodem, wystarczający. Szkoła, w której mieszkał bakałarz, czyli organista, opłacany przez proboszcza. Uczniów nie było, bo mieszkali tu sami luteranie, s. 81-82.

$\mathrm{S} t \mathrm{u}$ d z i e n i c e-kaplica. Wieś w starostwie bytowskim, w połowie w rękach szlacheckich, w połowie należała do starostwa. Znajdowała się tu kaplica drewniana, ostatnio wystawiona, pw. Świętej Trójcy. Jej opis. Miała skromne paramenty liturgiczne. Własnego uposażenie nie posiadała.

Opiekował się nią Wojciech Melcher, proboszcz z Ugoszcza, s. 83.

$\mathrm{D}$ ą b r ó w $\mathrm{k}$ a. Wieś w starostwie bytowskim, zamieszkała przez luteran. Był tam kościół filialny parafii Niezabyszewo, wystawiony w pruski mur, ale nie podano jego wezwania ${ }^{19}$. Uposażenie kościoła stanowił dom z ogrodem i ziemią, z czego był czynsz oraz drugi ogród, z czego użytkownik miał za zadanie dzwonić na nabożeństwa. Paramenta liturgiczne skromne.

Proboszcz miał dwa łany ziemi. Do parafii należała sama wiesz Dąbrówka. Nie było zabudowań plebańskich, ale plac, jaki był przy kościele, nadawał się pod zabudowę, s. 83-84.

\section{Wizytacja dekanatu lęborskiego}

L ę b o r k. Wprawdzie miasto to było zamieszkałe przez innowierców (heretyków), to jednak był kościół parafialny, solidny i murowany od fundamentów, pw. św. Jakuba Apostoła. Opis stanu świątyni. Paramenta liturgiczne.

Uposażenie stanowiły role w kilku miejscach położone, z których każda miała około jednej czwartej łana powierzchni, a ponadto dwa domki leżące na przedmieściu, z których był czynsz. Meszne pobierał proboszcz z wsi Małoszyce i Camelau, s. $89-90^{20}$.

\footnotetext{
${ }^{19}$ Dawniej podawano, że było to wezwanie św. Wojciecha.

${ }^{20}$ Po stronie 90 są wklejone cztery karty: $90^{\mathrm{a}}, 90^{\mathrm{b}}, 90^{\mathrm{c}}, 90^{\mathrm{d}} ; 90^{\mathrm{e}}, 90^{\mathrm{f}}, 90^{\mathrm{g}}, 90^{\mathrm{h}}$.
} 
$\mathrm{Z}$ a r z ą d z e n i $\mathrm{e}^{21}$ - [d e k r e t reformacyjny] biskupa włocławskiego i pomorskiego Konstantego Felicjana Szaniawskiego, wystawiony w Lęborku dnia16 października 1711 r., który widząc zaniedbania w parafii Lębork, dał specjalne uwagi, witrykusom i proboszczowi, ujęte w13 punktach, s. 90ª $-90^{c}$.

$\mathrm{S}$ t a t u s 1 ę b o r s k i, - zestawienie głównych dat i wydarzeń dotyczących okręgu (prefektury) lęborskiego - bytomskiego, s. 90 .

Wykaz kościołów [katolickich] w okręgu (prefekturze) lęborskim

L ę b o r k - prepozytura, gdzie nie było żadnego osiadłego katolika

N o w a W i e ś - kościół filialny, bez katolików.

G a r c z e g o r z e - parafia, bez katolików.

B i a ł o g a r d a - parafia, gdzie było kilku katolików.

Ł e b i e ń- parafia, gdzie nie było katolików.

B r z e ź n o [Lęborskie] - parafia, gdzie było kilku wieśniaków katolików.

R o zł a z i n o-parafia, gdzie było dziesięciu katolików, s. $90^{\mathrm{f}}$.

Wykaz zborów protestanckich w tym okręgu

Lębork, Gracigor, Jannowitz, Charbau, Roschitz, Łeba miasto, Sarbs - filia Łeby, Szwartau, Solin, Gniewin, Bożepole, Brzeżno, Dzięcielce, Bukowino, Labunie, s. $90^{\mathrm{g}}-90^{\mathrm{h}}$.

N o w a W i e ś. Wieś starostwa lęborskiego. Kościół, częściowo murowany, częściowo stawiany w pruski mur, pw. św. Katarzyny. Opis stanu świątyni. Uposażenie kościoła stanowiły pewne zapisane sumy, tu dokładnie wyliczone.

Uposażenie proboszcza stanowiło sześć łanów ziemi, z których pobierał roczną dzierżawę, ale powinien postarać się o odzyskanie i osobiste użytkowanie tych gruntów. Należały mu się jeszcze inne opłaty. Nie było ani plebani, ani domu dla nauczyciela, ale był ogród dla tego ostatniego, jak to wynikało z dawnych wizytacji, s. 91-92.

G a r c z e g o r z e. Wieś w starostwie lęborskim, z kościołem parafialnym pw. św. Marii Magdaleny. Opis świątyni, której prezbiterium było murowane, zaś nawa główna stawiana w pruski mur. Opis jej stanu. Uposażenie kościoła i parafii stanowiły różne, tu wyliczone zapisy, z których był roczny dochód.

Na uposażenie proboszcza składały się cztery łany ziemi, które były w dzierżawie za roczny czynsz oraz opłaty pobierane od wiernych. Meszne natomiast pobierano z następujących wsi: Garczegorze, Felchau ${ }^{22}$, Obliwitz ${ }^{23}$, Rekowo. Z tej

\footnotetext{
${ }^{21}$ Cztery poniższe akapity stanowią swoiste wtrącenie do tekstu protokółów wizytacyjnych.

${ }^{22}$ Miejscowość niezidentyfikowana.

${ }^{23}$ Obecnie Obliwice lub Oblewice.
} 
ostatniej wsi część należy do Garczegorza, cześć do Brzeźna. Plebania bardzo stara i z innymi zabudowaniami wymagała odnowy. Nie było domu dla nauczyciela, który byłby też potrzebny przynajmniej do dzwonienia. Nie było uczniów katolików. Był jednak plac szkolny, ale mieszkańcy wioski złośliwie zaprzeczali go i twierdzili, że do parafii należy. Było też i inne jeszcze uposażenie dla nauczyciela, ale było oddane za roczny czynsz. Zwrócono uwagę, że bez wiedzy Konsystorza nie powinno się tego czynić.

Nie ma wzmianki o proboszczu, s. 92-94.

R o z ł a z i n o. Wieś z starostwie lęborskim. Kościół pw. św. Wojciecha, wystawiony w pruski mur przed około 29 laty staraniem biskupa Madalińskiego. Opis świątyni.

Do uposażenie proboszcza należały dwa łany ziemi, ale ten oddał je za czynsz roczny, razem z przylegająca łąką. Ponadto należało mu się meszne z wsi: Rozłaziło, Goddensau, Felsztau, Damerkau ${ }^{24}$, Ketrzyno, Jeżewo, Nowcz, Osiek, Bożepole Wielkie, Bożepole Małe, Paroszyno, Lugwidz ${ }^{25}$, Albeck, Medeszyn, Chmielencz ${ }^{26}$. Dom plebański odbudował poprzedni proboszcz z Lęborka. Był dom dla nauczyciela, s. 94-95.

B r z e ź n o [Lęborskie]. Wieś w starostwie lęborskim, całkowicie opanowana przez innowierców, których minister, ze szkodą dla Kościoła katolickiego, publicznie głosił swoją naukę i sprawował sakramenty. Był tam kościół parafialny, drewniany, pw. św. Małgorzaty. Opis świątyni. Do uposażenia świątyni należała łąka, dająca roczny dochód. Dokumenty o przywilejach i uposażeniu parafii, zostały zabrane do Lęborka.

Proboszcz miał uposażenie z czterech łanów ziemi, które były w dzierżawie oraz z mesznego pobieranego z następujących wsi: Brzeźno, Puzicz, osada młyńska Mondrzyn ${ }^{27}$, Howenfeld ${ }^{28}$, Kaczkowo, Kuson i osada młyńska tej nazwy ${ }^{29}$, Lantz $^{30}$. Dom plebański dobry, ale zabudowania gospodarcze wymagały wielkiej naprawy. Dla nauczyciela był dom i pół łana ziemi, ale siłą zabrali to innowiercy dla swojego nauczyciela, ale nauczycielowi katolickiemu wybudowali inny dom, za zabraną zaś ziemię płacili mu roczny czynsz, Było to jednak mniej, niż to mówiły o jego uposażeniu poprzednie wizytacje.

Parafią zarządzał, na mocy połączenia z parafią lęborską, Andrzej Korsz, kanonik włocławski ${ }^{31}$, s. 95-97.

B i a ł o g a r d a. Wieś w starostwie lęborskim, cała w rękach innowierców.

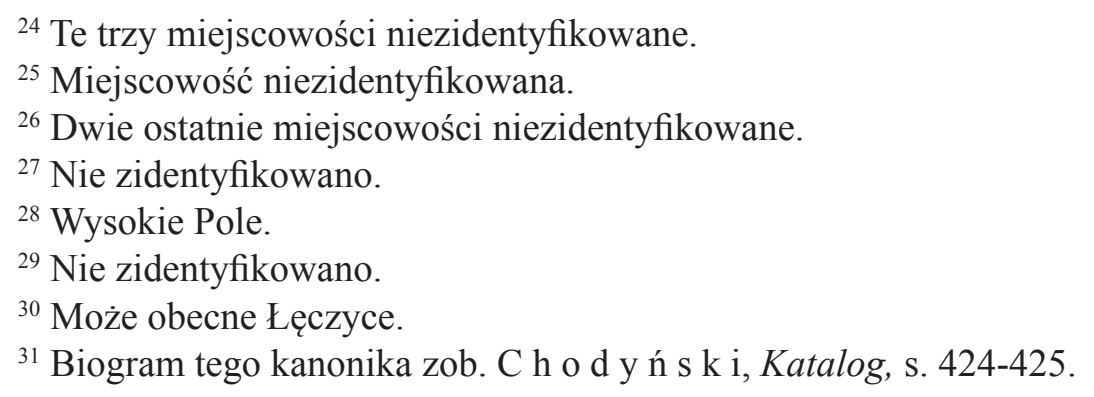


Kościół parafialny stawiany w pruski mur., pw. Oczyszczenia Najświętszej Marii Panny. Opis wyglądy i wnętrza świątyni. Do jej uposażenia należały procenty od sum zapisanych przez dziedzica na mieście Lęborku. oraz jeszcze inne, tu wyliczone. Paramenta liturgiczne.

Do uposażenia proboszcza należały cztery łany ziemi oraz prawo pobierania mesznego z wsi: Białogarda, Kramp, Massau, Scharsau, Widerkomesau, Oberkomesau, Gansz, Lesnechau, Roschitz, Stresu, Sdreven, Kopenau ${ }^{32}$, Frist, , Frist Szlachecki. Dom plebański i zabudowania gospodarcze wymagały naprawy.

Nie wspomniano o proboszczu, , s. 97-99.

Ł e b i e ń. Wieś w starostwie lęborskim, z kościołem drewnianym, pw. św. Michała Archanioła. Opis świątyni. Na uposażenie kościoła składała się łąka, dająca dwa wozy siana, z której mieszkańcy wsi dają roczny czynsz z tytułu dzierżawy. Były też inne jeszcze dochody, głównie z zapisów, tu dokładnie wyliczonych.

Uposażenie proboszcza stanowiły dwa łany ziemi, jak to z dawnych wizytacji wynika, ale była ta ziemia w dzierżawie za roczny czynsz. Do parafii należała sama wieś Łebień, z której proboszcz pobierał meszne. Nie było plebanii.

Parafią, jako filialną, zarządzał proboszcz z Białogardy, s. 100-101.

\section{Wizytacja dekanatu starogardzkiego}

P o g ó d k i33. Wieś opata z Pelplina, z kościołem parafialnym drewnianym, starym, który, z polecenia opata Skoraszewskiego, został w połowie rozebrany i w jego miejsce miał być wystawiony nowy, ale po założeniu fundamentów prace przerwano. Ponieważ pozostało prezbiterium ze starego kościoła, tu sprawowano nabożeństwa. Ten kościół nosił wezwanie św. Piotra i Pawła. Opis świątyni. Na uposażenie kościoła był łan ziemi we wsi Kosminek. Składano też ofiary. Paramenty liturgiczne.

Na uposażenie proboszcza składały się grunta i łąki, dosyć dokładnie tu opisane oraz cztery łany ziemi we wsi Kosmitko. Ponadto we wsi Kleszczewo, gdzie były już tylko ruiny dawnego kościoła filialnego, miał proboszcz także cztery łany i dwa domy, z czego pobierał czynsz. Natomiast meszne miał z wsi: Kobyle, Czernichowo, Głodowo, Bunkrowy, Więckowy, Jaroszewy, Wałdowko, Kleszczewo, Jezierze, Kosmitko, Pogutki, Malarek, Deka. Ponadto w pobliskim jeziorze, zwanym Popówek, miał proboszcz prawo połowu ryb zimą. Wiernych było około 600 osób.

Było bractwo Aniołów Stróżów, zaprowadzone w 1634, gdy opatem pelplińskim był Leonard Dembowski. Własnego uposażenie nie posiadało.

Dom plebański przez aktualnego proboszcza odbudowany. Także dla organisty i nauczyciela był nowy dom. Otrzymywał on wynagrodzenie z kasy bractwa

\footnotetext{
${ }^{32}$ Większośc z tych miejscowości nie została zidentyfikowana.

${ }^{33}$ Wówczas pisano ,pogutki”.
} 
oraz od parafian. Aktualnie nie było przytułku, ale dawniej, jak świadczą ludzie starzy, taki się tu znajdował.

Parafią zarządzał Jakub Bernard Król, dziekan starogardzki, tu rezydujący, s. 105-108.

S t a r o g a r d [Gdański]. Miasto królewskie z kościołem murowanym pw. św. Mateusza. Przed niewielu laty, jak mówi o tym ostatnia wizytacja Albinowskie$\mathrm{go}^{34}$, świątynia była znacznie zniszczona, ale została znacznie poprawiona staraniem ówczesnego wikariusza starogardzkiego, a obecnego proboszcza „Neophaniensis" "35. Opis stanu świątyni. Dochód parafii stanowił łan ziemi z ogrodem, z czego był czynsz oraz drugi ogród za rzeką, z małym domkiem i zabudowaniami gospodarczymi, też dającymi dochód. Wykaz paramentów liturgicznych.

Bractwo Różańcowe, założone w 1636 r., które zachowywało należycie swoje statuty oraz posiadało własne wyposażenie liturgiczne, tu opisane.

Proboszcz posiadał na swoje utrzymanie cztery łany ziemi w Stargardzie oraz także cztery łany przy zniszczonym już kościele św. Jana. Ponadto miał czterech kmieci osiadłych przy uposażeniu prepozytury św. Jerzego w samym mieście, a także folwarczek za miastem, z trzema domkami, gdzie pracowali kmieci. Miał też prawo propinacji i pobierał pewne opłaty z miasta. Natomiast meszne pobierał z wsi: Humino, Rokocin, Widz, Barkowy, Klincz, Zamek starogardzki z Nową Wsią, Kuczborowo. Katolików znajdowało się ogółem około 600 osób. Dom proboszcza dosyć wygodny, ale znacznie zniszczony i miasto powinno go odbudować.

Dla organisty i kantora był dom, w którym kantor uczył około 15 chłopców. Obydwaj otrzymywali wynagrodzenie z parafii.

Szpital św. Jerzego za murami miasta, z jednym pomieszczeniem, gdzie mieszkało dziewięciu ubogich. Pewien dochód posiadał z czynszów z posiadanych i wydzierżawianych domów.

Proboszczem był Franciszek Chmielewski, kapelan biskupa włocławskiego, utrzymujący to rezydującego wikariusza Tomasza Muchowieckiego, s. 108-111.

N o w a W i e ś. Wieś starostwa starogardzkiego ze świątynią drewnianą, filialną starogardzkiej parafii, pw. św. Anny, wybudowaną niedawno z drewna, z ofiar samych parafian. Opis świątyni. Nie posiadała ona ani własnego uposażenia, ani wyposażenia w Paramenty liturgiczne.

Proboszcz posiadał cztery łany ziemi. Do parafii należała jedynie wieś parafialna, s. 111-112.

J a b ł o w o. Wieś królewska należąca do starostwa gniewskiego, ze świątynią murowaną, pw. św. Wawrzyńca, z wieżą znacznie uszkodzoną przez pożar. Parafia ta, z braku duchownego, została złączona z parafią w Stargardzie. Na uposażenie

${ }^{34}$ To pewnie późniejszy biskup sufragan włocławski - jego biogram zob. C h o d y ń s k i, Biskupi sufragani, s. 66-67

${ }^{35}$ Może chodzi o Nową Cerkiew. 
kościoła były dwa domki, z których był roczny czynsz. Skromne Paramenta liturgiczne.

Uposażenie proboszcza składało się z czterech łanów ziemi i dwóch domków, z czego był roczny czynsz. Do parafii należała jedynie wieś Jabłowo. W domu plebańskim, w złym stanie, mieszkał dzierżawca. Był dom dla nauczyciela, ale takowego nie było, s. 112-113.

B o b o w o. Wieś królewska w starostwie gniewskim, z kościołem stawianym w pruski mur, pw. św. Wojciecha. Opis świątyni. Uposażenie kościoła stanowił łan ziemi z zapisu starosty gniewskiego księcia Radziwiłła, z czego parafia miała dochód. Ponadto były jeszcze domy dające czynsz roczny. Paramenta liturgiczne.

Uposażenie proboszcza składało się z gospodarstwa rolnego, mesznego i akcydensu. Ziemi były cztery łany i łąki oraz ogród lezący pomiędzy posiadłością kmiecia nazwiskiem Czajka, a posiadłością karczmarza nazwiskiem Kobuz. Ogród ten, obejmujący trzy morgi, dany był proboszczowi przez mieszkańców wsi. Meszne pobierał z wsi Bobowo, Wysoka oraz z folwarków Żabienko i Smoląg. Dom plebański dosyć wygodny, z zabudowaniami gospodarczymi. Dom dla nauczyciela i organisty, który uczył dzieci dosyć dobry. Ponadto miał on jeszcze uposażenie od mieszkańców wyżej wymienionych wsi oraz dodatkowo z parafii i wsi Dąbrówka. Przytułek, znacznie zniszczony, gdzie mieszkało trzech ubogich, żyjących z jałmużny.

Proboszcz Szymon Ćwikliński, s. 113-115.

$\mathrm{D}$ ą b r ó w k a. Wieś w starostwie gniewskim, ze świątynią murowaną, pw. Podwyższenia Świętego Krzyża, Opis kościoła. Na uposażenie kościoła był łan ziemi zapisany przez Albrechta Radziwiłła, wolny od wszelkich obciążeń. Ponadto domek, dający także roczny dochód. Paramentów liturgicznych praktycznie nie było.

Proboszcz miał cztery łany ziemi, uprawianych przez dwóch wieśniaków, płacących czynsz.

Parafią administrował proboszcz z Bobowa, czyli była ta parafia filialną parafii w Bobowie, s. 116.

P i ń c z y n. Wieś królewska w starostwie kiszewskim. Świątynia drewniana, niedawno restaurowana, pw. ś. Elżbiety. Opis stanu kościoła. Paramenta liturgiczne.

Uposażenie proboszcza stanowiły cztery łany ziemi oraz meszne z wsi: Pińczyn, Samlino, Góra, Pisienica, Sucimin, Suciminek, Pałubinek. Dom plebański dosyć dobry, ale brak zabudowań gospodarczych. Dla nauczyciele był ogród, dom bowiem niedawno się spalił.

Parafią administrował proboszcz parafii Pogódki, s. 117-118.

Z b l e w o. Wieś królewska w starostwie borzechowskim. Kościół drewniany, 
pw. św. Michała Archanioła i św. Mikołaja, tak bardzo zniszczony, że nadawał się jedynie do odbudowy od podstaw. Opis świątyni. Paramenty liturgiczne.

Uposażenie proboszcza stanowiły cztery łany ziemi z łąkami, ogrodami i innymi dodatkami. Ponadto był ogród, znajdujący się w pobliżu plebanii, darowany niegdyś proboszczowi Lwoweckiemu przez szlachcica Podlewskiego, starostę borzechowskiego. Ponadto w jeziorze zblewskim miał prawo połowy ryb. Meszne zaś pobierał z następujących wsi: Zalewo, Borzecho, Iwiczno, Bytonia, Radziejewo, Wieradowo, Lipe, Bląmfeld, Kaliska, Piła Lipska, Białachówko. Dom plebański i zabudowania gospodarcze dosyć dobre. Także dla nauczyciela był mały domek.

Nie podano imienia i nazwiska proboszcza, s. 118-119.

L u b i e c h o w o. Wieś w starostwie borzechowskim ze świątynią parafialną, drewnianą, pw. św. Jakuba i św. Barbary. Opis stanu świątyni. Paramenty liturgiczne.

Uposażenie proboszcza stanowiły cztery lany ziemi i meszne z wsi: Lubicchowo, Steklno, Zielona Góra, Bietowo, Osowo, Ocepel. Dom plebański bardzo mały i zniszczony. Dla nauczyciela nie było ani uposażenia, z wyjątkiem ogrodu. W przytułku, nie posiadającym własnego uposażenia, było trzech ubogich, żyjących jedynie z jałmużny.

Parafią administrował proboszcz ze Zblewa, Andrzej Łęski.

C z e r s k ${ }^{36}$. Wieś w starostwie tucholskim, z kościołem parafialnym, drewnianym, pw. św. Marii Magdaleny. Opis świątyni. Paramenta liturgiczne.

Według przywileju z czasów krzyżackich jeszcze, przechowywanych na zamku w Tucholi, uposażenie proboszcza składało się z pięciu łanów ziemi, łąki zwanej Rozgard i drugiej z nazwą Bielawa. Ponadto był domek dający roczny czynsz oraz prawo połowu ryb w jeziorze sąsiadującym z plebanią. Meszne pobierał proboszcz z wsi: Czersk, Wieczorowa, Malechin, Retel, Zapadowo, Lutom, Legband, Uboga, Kongerski, Liczorawski na Ostrowach, Wielgoszyk, Łosiny, Karcze, Twarzewnica, Kodnia.

Dom plebański zbyt mały i zniszczony, ale zabudowania gospodarcze dobre. Był sad owocowy obok plebanii. Dla nauczyciela, który był i organistą, znajdował się domek z ogrodem, a opłacał go proboszcz i parafianie.

Proboszczem był Tomasz Gradzikowski,s. 121-123.

Ł ą g. Wieś w starostwie tucholskim. Znajdował się tu kościół filialny parafii w Czersku, pw. Narodzenia N.M.P. Bardzo zniszczony. Odprawiano tu, w co trzecią niedzielę.

Uposażenie stanowiły cztery łany, ale był to głównie las, który w miarę potrzeby zagospodarowywał proboszcz. Meszne zaś pobierał z wsi: Łąg, Brusy, Badzimirowice, Zawada, Złemięso, Bądzimirowski, Zimne Zdroje, Tleniny. Nie by-

\footnotetext{
${ }^{36}$ Wówczas pisano „Czyrsk”.
} 
ło ani domu plebańskiego, ani dla nauczyciela. Był jednak jeden domek, z którego pobierano czynsz.

Parafią administrował proboszcz z Czerska, s. 123-124.

$\mathrm{K}$ i s z e w a. Wieś w starostwie kiszewskim, w której znajdował się kościół parafialny drewniany, pw. św. Marcina. Paramenty liturgiczne.

Wsie należące do parafii kiszewskiej: Stara Kiszewa, Zamek Kiszewski, Pałubino, Stare Polaszki, Nowe Polaszki, Chwarzno, Bożepole, Malikowy, Tułowo, Bartel, Piec Smolany, Konarzyny, Bartoszowy Las, Chwarzcienko, osada młyńska: Kiszewy, Ruda, Bukowiec, Biszewa, Pałubin,, osady pieców (pewnie węgiel drzewny lub smołę robiono) Smolane, Studzience, Babie, Ropuch, Wygonin, osada rybacka Rakowski i Dobrek, osady opuszczone: Nierybno, Ciegadlo, Thesarz. Dom plebański bardzo mały, z jednym pomieszczeniem. Szkoła, gdzie mieszka organista uczący także dzieci, wystarczająco dobra. Organista opłacany jest przez parafię i przez wiernych.

Nie wspomniano wiadomości o proboszczu, s. 124-125.

P o 1 a s z k i. Wieś królewska z małym drewnianym kościołem filialnym parafii w Kiszewej, pw. św. Mikołaja. Opis świątyni.

Uposażenie proboszcza stanowiły dwa łany ziemi z łąkami oraz akcydens. Domu dla proboszcza i nauczyciela nie było. Przytułek, niedawno zbudowany przez Zofię Czapską, podkomorzynę malborską, ale już zniszczony i nie było w nim podopiecznych. Jako uposażenie powinien dostawać dotacje z dworu Polaszki, ale z tego się nie wywiązywano, s. 126.

K o k o s z k o w y. Wieś królewska w starostwie starogardzkim, a w niej murowany kościół parafialny pw. św. Barbary. Opis świątyni ${ }^{37}$.

Proboszcz miał uposażenie z czterech łanów ziemi z łąkami oraz cztery domy, z których pobierał czynsz. Ponadto miał meszne z wsi: Kokoszkowy, Zduny, Szpegawsk, Ciecholewy, Bączek, Linowiec, Krąg, Żabno. Mały dom plebański i inne zabudowania wymagały dużych napraw. Domek dla nauczyciele i organisty mały, Był on opłacany przez proboszcza.

Nazwiska proboszcza nie podano, s. 127-128.

K 1 o n ó w k a. Wieś królewska w dzierżawie szlacheckiej rodziny Wulf. Świątynia parafialna murowana, pw. św. Katarzyny. Opis kościoła i paramentów liturgicznych.

Uposażenie proboszcza stanowiły cztery łany ziemi i meszne z Klocówki i Rywałdu. Dom plebański i zabudowania gospodarcze bardzo zniszczone. Domek dla nauczyciela z ogrodem został zabrany na użytek miejscowego dziedzica, s. 128129.

${ }^{37}$ Pozostawiono pół pustej strony, widać miano tam cos jeszcze dopisać. 


\section{Wizytacja dekanatu gdańskiego}

Pr ę g o w o. Wieś należąca do klasztoru św. Brygidy w Gdańsku, z kościołem z kamienia, pw. Bożego Ciała. Opis świątyni i paramentów liturgicznych.

Uposażenie proboszcza stanowiło gospodarstwo rolne, meszne i akcydens. Gospodarstwo, zwane Popówka, składało się częściowo z gruntów obsiewanych, częściowo z lasów, o powierzchni około piętnastu łanów. Na tym terenie jest wieś parafialna, z młynem, z którego proboszcz miał roczny dochód. Miał on też prawo propinacji. Meszne pobierał z wsi: Pręgowo, Bilkowo, Bilkówko, Goszyno, Kleszczewo, Czerniwo, Domachowo, Buszkowy, Lisewo, Żuławka, Ostroszki, Bąkowo, Zaskoczyno, Czapielsk, Stegwaldt, Żabrcz, Walcz i Maleczno, osada Papiernik w Wielkim Bolkowie, osada kowala w Bilkowie. Dom plebański dosyć wygodny, zbudowany z pruskiego muru przez aktualnego proboszcza, Jana Stefana Janowicza, kanonika włocławskiego ${ }^{38}$. Nauczyciel i organista miał dobry dom i opłacała go parafia.

Proboszcz, tu rezydujący, miał jeszcze wikariusza, Franciszka Markiewicza, s. 131-133.

M i e r z e s z y n [po niem. Meysterwald]. Wieś królewska, ze zniszczonym kościołem pw. św. Bartłomieja. Mieszkańcy wsi prawie wszyscy byli innowiercami. Paramenta liturgiczne, a więc kielich z pateną, znajdowały się w kościele św. Wojciecha.

Uposażenie proboszcza stanowiły cztery łany ziemi. Do parafii należała wieś Mierzeszyn i Przywidz. Zabudowania plebańskie znajdowały się w ruinie, s. 133.

P r z y w i d z. Znajdował się tam kościół, a raczej kaplica w pałacu szlachciców Linda, innowierców, i przez lat wiele im służyła. Ostatnio, po śmierci Lindy, gdy córka wyszła za mąż za Bernarda Trzcińskiego i wróciła na łono Kościoła, biskup kujawsko-pomorski Stanisław Szembek, osobiście zjawił się w tej świątyni i przejąwszy ją z rąk innowierców, rekoncyliował i sam odprawił pierwszą mszę. Jednak nie było tu stosownego uposażenia, dlatego aktualnie nie ma tu ani proboszcza, ani kapelana, i dlatego znowu korzystają z niej innowiercy, zaś wieś została włączona do parafii Mierzeszyn, s. 134.

Ż u $\nmid$ a w k a. Wieś szlachecka, w której dawniej była świątynia parafialna, ale obecnie istnieje jedynie kaplica mała pw. św. Małgorzaty, jako filialna parafii w Pręgowie. Opis kaplicy i wyposażenia, s. 134.

Pr z o d k o w o. Wieś królewska. Kościół parafialny, drewniany, pw. św. Andrzeja Apostoła. Opis świątyni i wyposażenia w paramenty liturgiczne.

$\mathrm{Na}$ uposażenie proboszcza były cztery łany ziemi, meszne i dochody z akcydensów. Meszne pobierano z wsi: Przodkowo, Młynik, Smałdzino, Kobusewo

${ }^{38}$ Biogram tego kanonika zob. C h o d y ń s k i, Katalog, s. 327-328. 
z osadą młyńską, Kossowo, Załęże, Pomieczyno. Zabudowania plebańskie i gospodarcze dobre, niedawno budowane.

Proboszcz Stanisław Hejmowski, s. 134-135.

$\mathrm{K}$ i e $1 \mathrm{n}$ o. Wieś królewska w dzierżawie Łebińskich, z kościołem parafialnym, budowanym w tzw. pruski mur, pw. św. Marii Magdaleny. pis świątyni i jej wyposażenia w paramenty liturgiczne.

Uposażenie proboszcza stanowiły cztery łany ziemi i meszne z wsi: Kielno gdzie była karczma i osada młyńska, Warzno, Warzenko, Mniszego, Kołeczkowo z karczmą i osadą młyńską, Mieszkowo z karczmą, Kminka, Kowal, Szpank, Wiczbino, Dobrzewina, Głodowo, Czernia, Brzanka, Bojanie z karczmą, Bieszk, Dębowa, Czarna Dąbrowa, Grobowiec. Zabudowania plebańskie dobre. Nauczyciel, opłacany przez parafię, a także parafian, miał swój domek oraz uprawiał kawałek ziemi zapisany dlań, aby śpiewał różaniec, s. 136-138.

$\mathrm{S}$ z e n w a 1 d t. Wieś królewska z kościołem, a raczej kaplicą pw. św. Mikołaja. Jej opis. Na skraju cmentarza, przy drodze publicznej znajdowała się maleńka kapliczka z obrazem św. Mikołaja. Paramenty liturgiczne.

Dawniej dla proboszcza były cztery łany ziemi, ale aktualnie jest $\mathrm{z}$ tego tylko część. Proboszcz pobierał meszne z wsi: Szenwaldt, Donimierz Mały, Donimierz Wielki, s. 138.

Ż u k o w o. Wieś zakonnic norbertanek i klasztorem. Świątynia parafialna, oddzielona od klasztoru, pw. św. Jana Chrzciciela, murowana. Jej opis. Na uposażenie kościoła był procent od pewnej sumy zapisanej przez Wawrzyńca Borkowskiego, kanonika warmińskiego. Paramenty liturgiczne.

Proboszcz ma uposażenie z czterech łanów ziemi z racji tego, że był rektorem kościoła klasztornego. Ponadto miał meszne z wsi: Lniska, Borkowo, Moilkowo, Sitno, Lezno, Lezienko, Pępowo, Glincz, Skrzeszewo, Tokary, Mniszego, Kczewpo, Przyjaźń, Niestopowo, Sulmino, Htominko, Łapino, , Mankoszyno, Wedlino. Zabudowań plebańskich nie było, ponieważ proboszcz był spowiednikiem sióstr i mieszkał przy klasztorze. Wspomniano o przytułku św. Elżbiety. O innych pracowników kościoła troszczył się klasztor.

Proboszczem był Jan Leyding, jednocześnie spowiednik sióstr, s. 139-140.

M a t a r n i a. Wieś opata oliwskiego z murowanym kościołem parafialnym pw.św. Walentego. Opis świątyni. Uposażenie kościoła stanowiły dwa domy. W jednym mieszkał organista, a z drugiego parafia pobierała czynsz. Paramenta liturgiczne miały być wystarczające, jednak ich nie wyliczono.

Na uposażenie proboszcza były cztery łany ziemi w Matarni i podobnie cztery łany w Baninie, z czego pobierano roczny czynsz, czyli były w dzierżawie. Meszne szło z wsi: Materna, Banin, Klukowo, Besowo, Czaple, Basenowo, Kokoszkowy, Pokrzywno, Smogorzyno, Kiełpin, Wenkowy, Kiełpinek. Zabudowania plebańskie dobre.

Parafią administrował zakonnik cysters z Oliwy, nazwiskiem Sękowski, który 
tu nie rezydował, ale w niedziele i święta przyjeżdżał odprawiać nabożeństwa, 140-142.

C h w a s z c z y n. Wieś biskupa włocławskiego, z kościołem parafialnym, częściowo drewnianym, częściowo z pruskiego muru, pw. Apostołów Szymona i Judy. Opis świątyni i wyposażenia w Paramenty liturgiczne.

Na uposażenie proboszcza były cztery łany ziemi w Chwaszczynie oraz także cztery łany w Kacku, gdzie był kościół filialny, aktualnie zniszczony. Cała ta ziemia była w dzierżawie na roczny czynsz. Meszne proboszcz pobierał z wsi: Chwaszczyn, Wielki Kack, Mały Kack, Kolebka, Tuchomie, Borowiec, Lublewo. Ponadto proboszcz miał prawo połowu ryb w jeziorach. Plebania spłonęła przez 7 laty przez nieuwagę dzierżawcy, a także pozostałe zabudowania bardzo ucierpiał. Nauczyciel uczący dzieci podstaw wiary i czytania, mieszkał w małym domku.

Parafią administrował proboszcz z Oksywia, Piotr Slesiger, s. 142-144.

O 1 i w a. Wieś, w której znajduje się klasztor cystersów. Oprócz świątyni klasztornej, znajduje się kościół murowany, konsekrowany 18 I 1604 r. przez sufragana włocławskiego Franciszka Ląckiego ${ }^{39}$. Opis stanu świątyni, s. 144.

G d a ń s k - kaplica pw. Ś w i ę t e g o D u c h a, fundowana przez króla Jana III [Sobieskiego] przy kościele parafialnym w Gdańsku, zajętym przez protestantów. Kaplicę konsekrował biskup Bonawentura Madaliński. Opis stanu kaplicy i jej wyposażenia.

Uposażenie proboszcza składało się z czynszów od zapisanych sum, tu wyliczonych oraz z tzw. akcydensów. Proboszcz posiadał swoją wygodną rezydencję. Zakrystianin i organista nie mieli własnych domów, ale pobierali zapłatę.

Z prezenty królewskiej parafią administrował kanonik włocławski Jan Stefan Janowicz $^{40}$, który miał tu swojego rezydującego wikariusza, s. 145-146.

Ś w i ę t y W o j c i e c h. Wieś biskupa włocławskiego z murowanym kościołem parafialnym pw. św. Wojciecha. Opis świątyni i wyposażenia w paramenty liturgiczne.

Uposażenia proboszcza stanowią cztery łany ziemi lokowane na roczny czynsz oraz dom, także wydzierżawiony. Meszne dochodziło z wsi: Oruń, Hamburga, Pruszcz, Kiemlade, Lepcz, folwarki Cyplau, Rostau i Giszkau, Straszyn, Będzieszyn, Swincz, Bartlin, Wojanowo, Rusoczyn, Borchfeld, aram, Prędzieszyn, Chudomin, Mackowo, Borenczyn, Arciszewo, Golemkowo, Schönfeldt. Dom plebański z pruskiego muru, ale wymagający naprawy.

Za rzeczką Radunia znajdował się lasek, należący do proboszcza, a w nim murowana kaplica z ołtarzem z obrazem św. Wojciecha. Szkoła, niedawno odbudowana, ale nie było nauczyciela i dzieci do nauki.

\footnotetext{
${ }^{39}$ Biogram tego biskupa zob. C h o d y ń s k i, Biskupi sufragani, s. 46-49.

${ }^{40}$ Biogram tego kanonika zob. C h o d y ń s k i, Katalog, s. 327-328.
} 
Był domek dla organisty, który otrzymywał roczną zapłatę oraz posiadał nieco (morgę) ziemi.

Proboszczem był Ludwik Fantoni, kanonik warmiński, za dyspensą tu nie rezydujący, zaś administrację posiadał Jan Janowicz, na miejscu zaś pracował Jan Preiss, s.146-148.

Ł ę g o w o [po niem. Langnau]. Wieś opata oliwskiego. Kościół parafialny, murowany, pw. św. Mikołaja. Jej opis. Parafia posiadała pięć domów, z których brano czynsz. Opis wyposażenia w paramenty liturgiczne.

Proboszcz zaś na swoje wyposażenie miał dwa łany ziemi z należącymi łąkami oraz dom, z którego miał czynsz, a także akcydensy. Meszne pobierał z wsi: Langnowo, Skowarcz, Grebin. Zabudowania plebańskie wygodne, stawiane w pruski mur, wymagające naprawy. W szkole, ostatnio nieco naprawionej, mieszkał nauczyciel, uczący czytania, a także muzyki, za co miał wynagrodzenie, s. $149-150$.

R ó ż y n y [po niem. Rozemberg]. Wieś królewska z murowanym kościołem parafialnym pw. św. Wawrzyńca. Jej opis i wyposażenie w paramenty liturgiczne.

Dla proboszcza były cztery łany ziemi oraz łąka zwana Popówka, z której pobierał czynsz. Był też wydzierżawiany dom. Do parafii należała jedynie wieś Różyny. Nie bądź plebanii, a jedynie plac po niej,. na którym któryś z wieśniaków, za zgodą, postawił mały domek. W szkole mieszkał organista, uczący dzieci, s. $150-151$.

K ł o d a w a. Wieś należąca do klasztoru w Lądzie (cysterskiego). Kościół parafialny z pruskiego muru, pw. św. Jakuba i jej opis. Wyposażenie w Paramenty liturgiczne.

Proboszcz miał dwa łany ziemi i jeden domek. Meszne pobierał z wsi: Kłodawa, Zła wieś, Małe Trąbki, Ulkowy, Kleszczewo, Lagusewo, Zakrzewko, Kłobuczewo, Kaski, Osada kowalska i osada młyńska w Żukcinie. Zabudowania plebańskie niedawno zbudowane i dobre, s. 152-153.

W o j a n o w o. Wieś szlachecka w posiadaniu Gisów, innowierców. Była tam niegdyś świątynia murowana pw. św. Mikołaja, teraz w zupełnej ruinie, s. 153.

\section{Wizytacja dekanatu tczewskiego}

R e k o w n i c a. Wieś szlachecka Gleysen Deręgowskich, z kościołem parafialnym, drewnianym, pw. św. Michała. Opis świątyni i wyposażenia.

Uposażenie proboszcza składało się z dwóch łanów ziemi, akcydensów i mesznego z wsi: Rekownica, Bendomin i Bendominko. Nie było zabudowań plebańskich, ale kolator przyrzekł odbudować, na pozostałym po dawnej plebanii 
gruncie, nową oraz powiększyć uposażenie proboszcza. Nie było też szkoły, jedynie plac po niej, s. 155.

A d a $\mathrm{m} \mathrm{o} \mathrm{w} \mathrm{o}{ }^{41}$. Wieś szlachecka Klińskich. Kościół parafialny, drewniany, pw. św. Mikołaja. Opis wyglądu i wyposażenia w paramenty liturgiczne.

Proboszcz miał na uposażenie cztery łany ziemi oraz meszne z wsi: Adamowo, Polesie Wielkie, Polesie Małe, Stawiska, Dębogóry, Luboń. Nie było domu ani dla proboszcza, ani dla nauczyciela, ale były po nich place.

Parafią administrował Jakub Krolau, dziekan starogardzki, s. 156-157.

G a r c z y n. Wieś szlachecka Stanisławskich, z murowanym kościołem parafialnym pw. św. Andrzeja Apostoła. Opis stanu świątyni i jej wyposażenia w pararamenty liturgiczne.

Proboszcz miał na uposażenie cztery łany ziemi oraz meszne z wsi: Garczyno, Rowne, Sobacz, Liniewka, Lubieszyn, Harnikowy, Płachty, Liniewo. Dom plebański, wygodny z dwoma pomieszczeniami, z dwoma ogrodami i zabudowaniami gospodarczymi, jednak wymagało to naprawy. Szkoła mała, ale mieszkał w niej organista, który zastępował nauczyciela.

Parafią administrował proboszcz z Wysina, który w co drugą niedzielę odprawiał w obydwóch kościołach, s. 157-158.

W y s i n. Wieś biskupa włocławskiego. Drewniany kościół parafialny, pw. Wszystkich Świętych. Opis stanu świątyni i wyposażenia w naczynia liturgiczne.

Proboszcz miał uposażenie w cztery łany ziemi, domek z którego pobierał czynsz oraz meszne z wsi: Wisino, Szarpaty, Skrzydłowo, Szumlis, Iłownica, Trzepowo, Stary Wiectz, Dolne Piekło, Hamernik, osada młyńska Skrzydłowo. Dom plebański dobry z zabudowaniami gospodarczymi. W szkole mieszkał organista, będący także nauczycielem, s. 158-160.

$\mathrm{M}$ i $\nmid$ o b ą d z. Wieś biskupa włocławskiego. Kościół parafialny, murowany i ładny, pw. św. Małgorzaty. Opis świątyni. Na opłacenie lampy przed Najświętszym Sakramentem były dwa domy, z których pobierano czynsz. Wykaz paramentów kościelnych.

Uposażenie proboszcza składało się z czterech łanów ziemi, ponadto z gruntów i łąki zwanych Grodzisko oraz z łąki zwanej Popówka42. Meszne pobierał proboszcz z wsi: Miłonądz, Mieszczyn, folwark Mieszczyn, Kolink, Rabielcz, Dabrówka, Zajączkowo, Żenisławek, Łukocin. Plebania, częścią stawiana z muru, częścią z pruskiego muru. Wykaz inwentarza żywego proboszcza. Była szkoła, w której mieszkał organista, uczący także dzieci i jego uposażenie, s. 160-162.

D a 1 w i n. Wieś królewska w starostwie sobkowskim. Kościół filialny parafii

${ }^{41}$ Wówczas pisano: „Adamowo”.

${ }^{42}$ Wielkość tej łąki określono na „sex jugerum”. Była to miara powierzchni, jaka można było zaorać parą wołów w jeden dzień. 
Miłobądź, drewniany, pw. św. Mikołaja. Opis świątyni. Uposażenia nie było. wyposażenie w paramenty liturgiczne skąpe, tu nie wyliczone.

Uposażenie proboszcza składało się z czterech łanów ziemi, na której wieśniacy zbudowali sobie domy mieszkalne, płacąc czynsz z mieszkań i ziemi. Były jeszcze dwa inne domy, jeden przy cmentarzu, drugi przy drodze wiodącej do Miłobądza, należące do proboszcza. Do kościoła tego należała jedynie wieś Dalwin. Nie było domu dla proboszcza i nauczyciela, s. 162-163.

G i e $\mathrm{m} 1$ i c e $\mathrm{e}^{43}$. Wieś należąca do zakonników jezuitów z Gdańska, z murowanym kościołem parafialnym św. Jana Chrzciciela, zaś prawo patronatu podzielone było pomiędzy miejscowego ordynariusza i zakonników. Opis świątyni i wykaz paramentów liturgicznych.

Proboszcz miał na uposażenie dwa łany ziemi i meszne z wsi Giemlice. Żadna inna wieś do parafii nie należała. Dom plebański dobry z dwoma ogrodami przy plebanii. Nauczyciel, który był też organistą, miał dobrą rezydencjęe i odpowiednie uposażenie.

Parafia zarządzał Wojciech Bassendorski, s. 163-164.

T c z e w ${ }^{44}$. Miasto królewskie ze wspaniałym, na sposób bazyliki, kościołem murowanym, pw. św. Mikołaja. Opis świątyni. Kościół posiadał uposażenie składające się z domów, dwóch łanów ziemi dla organisty i dzwonnika, a także z pewnych zapisów. Wyposażenie w paramenty liturgiczne dosyć bogate.

Proboszcz posiadał trzy łany ziemi, a o czwarty łan toczył spór, a także dużą łąkę. Ponadto $\mathrm{z}$ domu zapisanego przez Michała Czarlińskiego miał roczny dochód. Z następujących wsi pobieral meszne: Czarlin, Bałdowo, Knybawa, Czyżykowi, Sztenbark, Suchostrzygi, Rokitki, Śliwiny. Zabudowania plebańskie z pruskiego muru były zniszczone i do odbudowy zobowiązane było miasto. Zabudowania gospodarcze także zniszczone. Ogród położony przy zabudowaniach parafialnych zabrało miasto pod zabudowę, ale dało inny, leżący poza murami miasta. Dla nauczyciela był dom leżący poza murami miasta, na cmentarzu. Mieszkał tam organista, będący jednocześnie nauczycielem. Był domek dla dzwonnika. Nie było szpitala i należało sprawdzić, dlaczego zaniknął. Miasto miało mały przytułek, s. 164-166.

S u b k o w y. Wieś należąca do biskupa włocławskiego, z parafialnym kościołem murowanym pw. św. Stanisława. Opis świątyni. Parafia miała domek, z którego pobierała czynsz. Wykaz wyposażenia w paramenty liturgiczne.

Proboszcz sobkowski miał cztery łany ziemi z łąkami, dwa domy oraz stałą opłatę z zamku sobkowskiego, czego jednak z reguły nie dawano. Meszne pobierał z wsi: Subkowy, Słońca Wielka, Narkowy, Gniszewa, Mała Słońca, Waćmierz, Waćmierek, Czarlin, Radostowo, Wulgłowo, Garcz. Zabudowania plebańskie dobre z dwoma ogrodami, jeden w bezpośrednim sąsiedztwie, zaś drugi pomiędzy

\footnotetext{
${ }^{43}$ Tu napisano „Gömlice”.

${ }^{44}$ Tu napisano nazwę „Dirszaviensis”.
} 
ogrodami wieśniaków, zwany Kapuśniaczek. Dla nauczyciela, który był jednocześnie organistą, znajdował się domek. Organista miał należyte uposażenie. Przytułek został niedawno odbudowany, nie posiadał własnego uposażenia. Przebywało w nim czterech ubogich żyjących z jałmużny ${ }^{45}$, s. 167-169.

G o r z e d z i e j. Wieś królewska w starostwie tczewskim. Kościół parafialny pw. św. Wojciecha. Opis świątyni. Na jej uposażenie było dwanaście domów, z których był czynsz. Skromne wyposażenie w paramenty liturgiczne.

Proboszcz miał cztery łany ziemi oraz domek nad rzeką Wisłą, jednak na gruncie parafialnym. Ponadto posiadał prawo propinacji. Dawniej były domy dla proboszcza i organisty, ale zostały zniszczone przez wylewy Wisły.

Parafia administrował proboszcz z Subkowych, s. 169.

L u b i s z e w o. Wieś królewska w starostwie tczewskim. Kościół parafialny, murowany, pw. Świętej Trójcy i dokładny jego opis. Kościół ma poważny dochód z składanych z okazji święta Świętej Trójcy ofiar z wosku, z innych jeszcze opłat oraz domu o dwóch pomieszczeniach, z których jedno miała szkoła, drugie zaś przytułek. Dokładny wykaz paramentów liturgicznych. Na uroczystość Swiętej Trójcy był przywilej odpustu zupełnego, zaś na Wniebowzięcie Najświętszej Marii Panny odpust cząstkowy.

Proboszcz posiadał osiem łanów ziemi, ale aktualnie jedynie cztery, ponieważ dawniejsi proboszczowie przez niedbalstwo oddali połowę w użytkowanie wieśniaków. Aktualny proboszcz grunta te rewindykował. Ponadto na gruncie proboszczowskim stały trzy domy, z czego miał roczny czynsz. Użytkownicy odpłacali też pracą, zwana szarwarkiem. Do niego należało także prawo propinacji. Meszne pobierał z wsi: Lubiszewo, Swarożyn, Goszyc, Liniewko, Wętkowy, Małżewo, Małżewko, Rękoczyn, Stanisławie. Zabudowania plebańskie dobre. Proboszcz miał też prawo połowu ryb. Była szkoła, w której mieszkał nauczyciel, będący także organistą. W małym przytułku mieszkało pięciu ubogich żyjących z samej jałmużny.

Proboszczem był Tomasz Długoński, dziekan tczewski, s. 170-172.

G o d z i s z e w o. Wieś opata z Lądu. Kościół parafialny, murowany, pw. św. Piotra i Pawła. Opis świątyni. Wykaz paramentów liturgicznych.

$\mathrm{Na}$ uposażenie proboszcza składały się cztery łany ziemi, dwa domy dające roczny dochód oraz meszne z wsi: Żygowice, folwark Damaszka, Turze Wielkie, Trzcińsk, Gołębiewo Średnie, Gołębiewo Małe, Gołębiewo Małe, Kobierzyno, Turze Małe, Rościszewo, Szczerbięcino, Boroszewo, Boroszewko. Nowy murowany dom plebański i dobre zabudowania gospodarcze. Dla nauczyciela, uczącego dzieci i będącego organista był domek z ogrodem, s. 172-173.

O b o z i n. Wieś szlachecka Sarławskich. Kościół parafialny, murowany,

${ }^{45} \mathrm{Nie}$ podano imienia i nazwiska proboszcza. 
będący filią parafii Godziszewo, pw. św. Michała Archanioła. Opis świątyni ${ }^{46}$, s. 174-174.

T r ą b k i ${ }^{47}$. Wieś królewska w starostwie sobowidzkim. Nie podano wezwania kościoła parafialnego, ale był on murowany. Opis świątyni i wyposażenia w paramenty liturgiczne.

Proboszcz na swoje utrzymanie miał cztery łany ziemi i dochód z trzech domów. Meszne pobierał z wsi: Trąbki Wielkie, folwark Trąbki, Ogonowo, Klepiny i osada młyńska Klepiny, Sobowidz i osada młyńska Sobowidz, Gostołowo. Dom plebański niedawno wystawiony, z zabudowaniami gospodarczymi dobrymi, a ponadto z zamku sobowidzkiego otrzymywał pewne daniny. Szkoły nie było, ale był plac, gdzie należało ją odbudować.

Parafią administrował niepodanego imienia Bardębas, s. 175-176.

S k a r s z e w y. Miasto królewskie z murowanym kościołem parafialnym pw. św. Michała Archanioła. Opis świątyni. Tradycja przekazała, że dawniej parafia miała dwa łany ziemi, następnie cztery domy, z nich jeden od nowa zbudowany przez prepozyta z Karczew, archidiakona pomorskiego. Wykaz paramentów liturgicznych.

Bractwo św. Anny, posiadające własne paramenty liturgiczne.

Uposażenie proboszcza, którego dokładny opis został, staraniem Jana Jurgowskiego, kanonika włocławskiego i prepozyta skarszewskiego ${ }^{48}$, ingorssowany do akt grodu w Skarszewach, dnia 23 VII 1700 r.. W protokóle tym podano odpis tego zapisu. Został on sporządzony dlatego, że innowiercy spalili dokumenty parafialne. Proboszcz posiadał sześć łanów ziemi oraz jakąś posiadłość ziemi i lasów pomiędzy Skarszewami a Więckowami. Miasto było zobowiązane do pewnych opłat. Posiadał także miał prawo propinacji. Dostawał pewne opłaty od piekarzy i rzeźników. Należały do niego jeszcze pewne grunta, jak dwa kawałki ziemi zwane Haffsztuki i tzw. Wilcze Łąki. Były też dochody z domów należących do proboszcza z wyjątkiem domu zajmowanego przez przytułek. Meszne zaś pobierał z wsi: Dęblin, Nigus, folwark Kamirowo, Mirowo, Bożepole, Czarnocin, Pawłowo, Pruska Karczma, Szczodrowo, Nowy Wierc, osada młyńska Szczodrowo, Barhuta, Sucha Huta, Czashuta, Górne Piekło, Świniebudy, Sztrukhuta. Część tych wiosek należy do parafii Szczordowo, która ma ponadto cztery łany ziemi. Informacja o Szczodrowie znalazła się w cytowanym zapisie ${ }^{49}$, s, 176-184.

S z c z o d r o w o. Wieś w starostwie skarszewskim, z kościołem parafialnym,

${ }^{46}$ Wygląda na to, że ten protokół nie został dokończony, ponieważ w księdze pozostało puste miejsce.

${ }^{47}$ W tekście pisano „Trąbki”.

${ }^{48}$ Biogram tego archidiakona pomorskiego zob. C h o d y ń s k i, Katalog, s. 346-348-350.

${ }^{49}$ Pozostawione puste miejsce w księdze może znaczyć, ze protokół ten nie jest cały, zresztą brak wielu wiadomosci, chociażby o imieniu proboszcza, chyba że był nim wspomniany z zapisie Jugowski. 
drewnianym, pw. Szymona i Judy Apostołów. Opis świątyni i paramentów liturgicznych. Domu dla proboszcza i nauczyciele nie było ${ }^{50}$, s. 185.

\section{Wizytacja dekanatu nowomiejskiego}

L u b i e ń. Wieś królewska w starostwie grudziądzkim. Kościół parafialny, wystawiony z pruskiego muru, pw. św. Małgorzaty. Opis świątyni.

Proboszcz miał na uposażenie cztery łany ziemi. Pozostały dochód był mesznego z następujących wsi: Tragosz, Mały Lubień, Wielki Lubień, Zajaczkowo, Montowy, Małe Zajączzkowo. Zabudowania plebańskie wymagają odbudowy, do czego zobowiązani są parafianie. Nie było też domu dla nauczyciela czy innego sługi przy kościele, s. 187-188.

B z o w o. Wieś królewska w starostwie grudziądzkim. Kościół parafialny, pw. św. Małgorzaty, wystawiony w pruski mur. Jego opis. Parafia posiadała na własność jezioro zwane Głowinek. Skromny wykaz paramentów liturgicznych.

$\mathrm{Na}$ uposażenie proboszcza składały się cztery łany ziemi i meszne z wsi: Bzowo, Grupa, Osieczek, Piła. a nadto trzy domy, dające roczny czynsz. Dom plebański wymagający naprawy. Był domek dla nauczyciela. Przytułek z jednym pomieszczeniem, bardzo zniszczony, bez własnego uposażenia, ale było w nim troje ubogich utrzymujących się z jałmużny.

Parafia administrowana przez Andrzeja Robak, proboszcza z Komórska, odprawiającego tu w co trzecią niedzielę, s. 188-189.

K o m ó r s k. Wieś biskupa włocławskiego. Kościół parafialny, drewniany, ale z wieżą murowaną, pw. św. Bartłomieja i św. Józefa. Przy kościele niedawno zbudowana kaplica murowana, pw. św. Michała Archanioła. Opis świątyni. Do parafii należał majątek Kurzejowo, dający roczny dochód. Wykaz paramentów liturgicznych.

Uposażenie proboszcza w cztery łany ziemi, pięć domków dających dochód, z akcydensów i mesznego z wsi: Komorsk Wielki, Komorsk Mały, Rulewo, Warlub. Dom plebański i zabudowania gospodarcze nowe. Szkoła i przytułek, po spaleniu, nie zostały jeszcze odbudowane Do odbudowy szkoły zobowiązani są parafianie. Dla szkoły był mały domek oraz uposażenie.

Proboszczem był Franciszek Robakowski, stale tu rezydujący, s. 190-191.

P ł o c h o c i n. Wieś szlachecka Jasińskich. Kościół parafialny, drewniany, zbudowany niezbyt dawno, staraniem Aleksandra Czapskiego, podkomorzego malborskiego, pw. św. Wawrzyńca, jeszcze nie konsekrowany. Opis świątyni i wyposażenia $\mathrm{w}$ paramenty liturgiczne.

Uposażenie proboszcza składało się z trzech łanów w Płochocinie i jednej we wsi Warlubie. Ponadto dwa domki w Płochocinie i jeden także w Warlubiu, z cze-

${ }^{50}$ Także ten protokół wydaje się być niedokończony, bo następna strona w księdze pozostała pusta. 
go miał dochód. Meszne szło z następujących wsi: Płochocin, Bękowo, Lipinki, osada młyńska w Bekowie, Borowy Młyn, Krzywim. Wiernych do opieki duszpasterskiej było około 300 osób. Dom plebański drewniany niewygodny, z ogrodem i zabudowaniami gospodarczymi.

Administrował parafią Wawrzyniec Böhm, dziekan nowomiejski, s. 191-193.

$\mathrm{N}$ o w e. Miasto królewskie z kościołem parafialnym, wyglądającym niczym bazylika murowana z wieżą, pw. św. Mateusza Apostoła i Ewangelisty. Dokładny opis świątyni. Na uposażenie świątyni był zapisany łan ziemi na dobrach Kozielec i Bochlin. Zapis poczyniony przez szlachciankę Annę Klgowską w 1642 r. Ponadto na restaurację świątyni był zapis uczyniony w $1688 \mathrm{r}$. w aktach wójtowskich w Świeciu przez Ludwika Durkrau i Jana Reszka, że wystawiona tam jatka rzeźnicza, po śmierci Jana Bener, na ten cel będzie przeznaczona. Wyposażenie w paramenty liturgiczne.

Bractwo różańcowe, założone w 1641 r. za zgodą biskupa Macieja Łubieńskiego i przeora konwentu [dominikańskiego] z Gdańska, na prośbę ówczesnego proboszcza i dziekana, Piotra Góreckiego. Bractwo to posiadało własne uposażenie oraz wyposażenie w paramenty liturgiczne.

Niedawno zaprowadzono nabożeństwo do św. Rocha przy ołtarzu tego patrona, na którym znajdowało się 16 dziękczynnych wotów.

Uposażenie proboszcza szło z czterech łanów ziemi i jeziora, ale małej użyteczności. Na mocy dawnej umowy miał proboszcz, w zamian za wyżej wspomniane uposażenie, otrzymywać dochód z miasta. Był zapis niejakiego Bartłomieja Szawłowskiego z obowiązkiem mszy za wiernych zmarłych. Pewien dochód miał też z miasta, chociaż opanowanego przez luteran. Meszne szło z miejscowości: miasto Nowe i zamek Nowemiasto oraz wsi: Mieliwe, Kozielec, Rychława, Mieliwko, Kamionka, Tril, Morgi, Konczyce, Łabędki. Wiernych było około 700. Zabudowania plebańskie w złym stanie i zgodnie z poleceniem królewskim, powinny być odbudowane przez miasto. Był domek zwany wikariatka, gdzie mieszkał wikariusz.. Były jeszcze inne domy, dwa nowe i dwa stare w ruinie. Do proboszcza należała wieża, blisko kościoła, w murach miejskich, gdzie urządził spichrz. Posiadał ogród, ale za murami miasta. Organista był wynagradzany przez miasto. Dom dla nauczyciela zły i mieszkał w nim organista, ale dzieci do nauki nie było, ponieważ wymarli z powodu zarazy. Dzwonnik miał mieszkanie w wieży miejskiej i miał zapłatę za dzwonienie z racji czyjejś śmierci. Dawniej był szpital, ale teraz pozostał po nim jedynie plac.

Kościół pw. ś. Jerzego poza miastem, murowany, ale nie posiadający własnego dochodu i paramentów liturgicznych. Nabożeństwo sprawował prepozyt z Nowego raz w miesiącu. Przy tym kościele znajdował się przytułek z dwoma pomieszczeniami, ale już zniszczony. Nie miał specjalnego uposażenia, poza małym ogrodem przy nim położonym. Znajdowało się tam pięciu ubogich żyjących z jałmużny.

Zarządzał nim oraz parafią Wawrzyniec Böhm, stale tu rezydujący i mający także wikariusza, s. 193-197. 
P i e n i ą ż k o w o. Wieś biskupa włocławskiego. Kościół parafialny, murowany, fundowany przez Oleskiego, pw. św. Jana Chrzciciela. Opis świątyni i jej wyposażenia w Paramenty liturgiczne.

Uposażenie proboszcza składało się z niepełnych czterech łanów ziemi, akcydensów i mesznego z wsi: Pieniążkowi, Półwiś, Dąbrówka, Smarzewo, Czerwieńska. Były jeszcze wsie: Ostrowie, Luchowo, Kolimaaga, Wiosła, które oddawały jedynie kolędę. Dom plebański w złym stanie, zabudowania gospodarcze dobre. Szkoły nie była, a plac po niej znajdował się w ubytkowaniu nauczyciela. Szpital wymagał pilnej naprawy. Ubodzy utrzymywali się z samej jałmużny.

Parafią administrował jako proboszcz Jan Latoszewicz, s. 197-199.

O p a 1 e n i e. Wieś szlachecka Döhofów, w dzierżawie Baranownej. Kościół parafialny wystawiony w pruski mur, pw. św. Piotra i Pawła Apostołów. Kościół i ołtarze konsekrował w 1665 r. biskup Stanisław Świecicki ${ }^{51}$. Opis świątyni i wyposażenia w paramenty liturgiczne.

Uposażenie proboszcza stanowiły cztery łany, w dużej części składające się z lasów, które przywłaszczył sobie dwór i stąd powstał spór. Dlatego w rzeczywistości uposażenie stanowiły akcydens i meszne z wsi: Meysterwald, Opalenie, Alpinek Mały, Alpinek Wielki ${ }^{52}$, Dom plebański w stanie złym. Szkoła została dawniej przez Wilhelma de Ladinghausen Vulff i nie została odnowiona.

Parafią administrował Andrzej Montowski, dziekan gniewski, odprawiający tu w co trzecią niedzielę, s. 199-200.

L a 1 k o w y. Wieś królewska w starostwie grudziądzkim. Murowany kościół parafialny pw. św. Barbary. Opis świątyni. Na uposażenie świątyni były trzy domki, z których był czynsz oraz z dawnego zwyczaju poszczególni parafianie dawali świadczenie zwane „campotorne” Wykaz paramentów liturgicznych.

Proboszcz miał cztery łany ziemi oraz łąkę jedną niedaleko domu plebańskiego i drugą pod „Kamionka”. Był też ogród. Dalszy dochód szedł z akcydensu i mesznego, oddawanego przez mieszkańców następujących wiosek: Lalkowy, Frąca, SmętowoSmętówko, Kopytkowo, Rynkówka, Włoszenica, Budziesz. Wiernych do opieki duszpasterskiej było około 350 osób. Dom plebański i pozostałe zabudowania wymagały restauracji. Był domek dla nauczyciela, czy raczej organisty. Aktualnie takiego nie było, ale w najbliższej przyszłości ma przybyć. 202.

Proboszczem, rezydującym na miejscu był Stanisław Żołądkowski, s. 200-

J a n i a. Wieś szlachecka innowierczymi Baranownej. Kościół parafialny murowany, wystawiony przed osiemdziesięcioma laty przez miejscowego dziedzica Piotra Kostkę i konsekrowany przez biskupa Macieja Łubieńskiego. Opis świątyni i wyposażenia w paramenty liturgiczne.

${ }^{51}$ Biogram tego biskupa sufragana żmudzkiego i biskupa chełmskiego, żyjącego w latach 16301696 zob. Stanisław Jacek Święcicki, w: Biskupi Kościoła w Polsce w latach 965-1999, Warszawa 2000, k. 440..

${ }^{52} \mathrm{~W}$ tym miejscy znajdują się dopiski inną ręką. 
Na uposażenie proboszcza były cztery łany ziemi oraz meszne $\mathrm{z}$ wsi: Jania Kościelna, Stara Jania, Leśna Jania, osada młyńska Kownatka. Wiernych było około 200 osób. Dom plebański i inne zabudowania wymagały naprawy. Dla nauczyciela, czyli organisty był domek i uposażenie, ale nie powiedziano, czy takowy był aktualnie, s. 202-204.

S k ó r c z. Wieś królewska w starostwie osieckim. Kościół murowany, pw. Wszystkich Świętych. Opis świątyni. Na uposażenie kościoła był czynsz z trzech domów ${ }^{53}$. Wykaz paramentów liturgicznych. Było bractwo pokutne nazywające się ,pomoc dla zmarłych”, zatwierdzone przez ordynariusza miejscowego, posiadające własne ustawy, Paramenty liturgiczne i samemu się rządzące.

Proboszcz miał sześc. łanów ziemi, ponadto dom z innymi czterema łanami, $\mathrm{z}$ czego pobierał czynsz. Były też inne zapisy sum na procent, tu wyliczone. Posiadał też prawo połowy ryb w pobliskim jeziorze. Meszne natomiast miał z wsi następujących: Skorcz, Wielbrądowo, Osiek. Wsie Koziniec, Kasperus, Skrzynia oddawały jedynie kolędę. Wiernych znajdowało się około 500 osób. Dom plebański zaczęto budować, ale z powodu trudnych czasów nie został ukończony, dlatego proboszcz mieszkał w maleńkim domku. Zabudowania gospodarcze dobre. Nauczyciel, a raczej organista, który uczył dzieci, miał mały domek i uposażenie od parafian. We wsi znajdował się przytułek nowo odbudowany, ale bez własnego uposażenia. Przebywało w nim trzech ubogich. Wykaz inwentarza w gospodarstwie proboszcza.

Proboszczem był Jakub Stanisław Mantecki, s. 204-206.

G r a b o w o. Wieś królewska w starostwie osieckim. Kościół wystawiony z pruskiego muru pw. św. Marii Magdaleny. Krótki opis świątyni. Na uposażenia kościoła był mały domek, z którego był czynsz ${ }^{54}$. Wykaz skromnego wyposażenia w paramenty liturgiczne.

Uposażeniem proboszcza były cztery łany ziemi i meszne z jedynej wsi parafialnej, Grabowa. Domu plebańskiego, szkoły i przytułku nie było, s. 206-207.

\section{Wizytacja dekanatu gniewskiego}

P i a s e c z n o. Wieś królewska w starostwie gniewskim. Murowany kościół parafialny, pw. Narodzenia Najświętszej Marii Panny. Opis świątyni i wyposażenia w Paramenty liturgiczne. Przed około dwudziestoma laty powstało bractwo skaplerza, zaaprobowane przez władzę diecezjalną, należycie organizujące swoje nabożeństwo.

Proboszcz, na mocy erekcji parafii, posiadał na uposażenie cztery łany ziemi. Ponadto, z fundacji księcia Radziwiłła, otrzymał jeszcze trzy łany, co zatwierdził monarcha Jan Kazimierz. Z tego funduszu był zobowiązany śpiewać w każdą

\footnotetext{
${ }^{53}$ Później dopisano, że przybył dom czwarty.

${ }^{54}$ Inna ręka dopisała później, że od 1724 r. sołtys z Grabowa miał jakąś powinność względem Kościoła.
} 
sobotę i święto maryjne oficjum o Matce Bożej. Na uroczystość Narodzenia Matki Boskiej przybywało tu wielu pielgrzymów dla uzyskania odpustu i nawiedzenia łaskami słynącego obrazu. W tym dniu proboszcz miał prawo propinacji. Posiadał też prawo połowu ryb oraz dochód z trzech domów. Meszne pobierał jedynie z wsi: Piaseczno, Jelenie, Bielsk. Wiernych znajdowało się około 300 osób. Dom plebański wygodny, niedawno wystawiony, podobnie jak i pozostałe zabudowania. Organista, który uczył dzieci, miał wygodny dom oraz łan ziemi, z zapisu Radziwiłła, z zobowiązaniem, aby z proboszczem śpiewał oficjum o Matce Bożej. W przytułku, nie mającym własnego uposażenia, przebywało sześciu ubogich, żyjących z samej jałmużny.

Parafia administrowana jest przez dziekana gniewskiego Andrzeja Montowskiego, tu rezydującego i mającego wikariusza, Macieja Jarzębińskiego, s. 211213.

D z i e r ż ą z n o. Wieś kapituły włocławskiej. Kościół parafialny, murowany, pw. św. Jakuba. Opis świątyni. Uposażenie kościoła jedynie z ofiar oraz z czynszu $\mathrm{z}$ jednego domu. Skromne wyposażenie w paramenty liturgiczne.

Uposażenie proboszcza z czterech łanów ziemi, dochodu rocznego z jednego domku oraz z mesznego z wsi: Dzierżązno, Gogolewo, folwark Brody. Wiernych było 203 osoby. Dom plebański bardzo stary i wymaga pilnej naprawy. W szkole mieszkał organista, który uczył dzieci i miał ogród oraz pobierał wynagrodzenie od parafian.

Parafią administrował Jan Witkowski, tu rezydujący, s. 213-214.

K r ó 1 ó w 1 a s. Wieś należąca do opactwa pelplińskiego, z kościołem zbudowanym niedawno z pruskiego muru, pw. św. Mikołaja, jeszcze nie konsekrowany. Opis świątyni. Na uposażenie świątyni był łan ziemi i domek, z czego był roczny czynsz. Skromne wyposażenie w Paramenty liturgiczne.

Proboszcz miał na uposażenie dwa łany ziemi, która wydzierżawiona, dawała roczny dochód. Meszne było jedynie z wsi Królówlas. Nie było domu plebańskiego i szkoły. Parafią, jako filialną administrował proboszcz z parafii Nowa Cerkiew (Neophana), odprawiając tu co trzecią niedzielę, s. 214-215.

B a r ło ż n o. Wieś królewska w starostwie osieckim. Kościół parafialny, $\mathrm{z}$ prezbiterium murowanym i nawą z pruskiego muru, pw. św. Marcina. Opis świątyni. na uposażenie kościoła był łan ziemi wydzierżawiony za czynsz roczny Jakubowi Skarszewskiemu. Ponadto były jeszcze trzy domki. Wykaz paramentów liturgicznych. Istniało bractwo św. Izydora, zaaprobowane przez Stolicę Apostolską i ordynariusza, nie posiadające własnego uposażenia, ale przestrzegające swoich statutów.

Proboszcz miał uposażenie z czterech łanów ziemi oraz czynsze z dwóch domów. Meszne miał z wsi parafialnych: Barłożono, Gąsiorki, Mirotki, Lipiagóra, Kierwald, Ponadto należała do niego posiadłość zwana Popówka, na co było potwierdzenie urzędowe z 20 IV 1621 r., zapisane w aktach grodu w Osieku, na życzenie ówczesnego proboszcza Jakuba Zardęckiego. Odpis tego aktu tu został 
przytoczony. Dom plebański drewniany, w złym stanie, a takjże wymagające naprawy zabudowania gospodarcze. Przy tych zabudowaniach był ogród i staw. Nauczyciel, i jednocześnie organista uczący dzieci miał dom z dwoma pomieszczeniami, opłacany przez parafię i parafian. W przytułku, mającym dwa pomieszczenia znajdowało się czterech ubogich, żyjących z jałmużny.

Parafią administrował Józef Majewski ${ }^{55}$, s. 215-218.

$\mathrm{C}$ z a r n y 1 a s. Wieś królewska należąca do rodziny szlacheckiej Bistram. Kościół parafialny z kamienia, pw. św. Andrzeja Apostoła. Opis świątyni. Na uposażenie świątyni był domek z morgą ziemi, darowany kościołowi przez księcia Radziwiłła. Wykaz paramentów liturgicznych.

Proboszcz miał na uposażenie cztery łany ziemi i dom, ale były one wydzierżawione. Meszne należało się ze wsi: Czarnylas, Zelgoszcz, Wda, Mermet. Dom plebański drewniany wymagający naprawy, zabudowania gospodarcze dobre. Dla nauczyciela, opłacanego przez kmieci, był dom i ogród.

Parafią administrował Michał Oczyński, proboszcz z Pączewa, s. 218-219.

$\mathrm{P}$ ą c z e w o. Wieś królewska w starostwie gniewskim. Kościół parafialny murowany, pw. Narodzenia Najświętszej Marii Panny. Opis świątyni. Na uposażenie miał dwa domy. Jeden z zapisu księcia Radziwiłła, a drugi na gruncie kościelnym, pomiędzy cmentarzem i szkołą, co dawało czynsz. Wyposażenie w paramenty liturgiczne.

Uposażenie proboszcza składało się z czterech łanów ziemi. Ponadto były dwa domy. Przy jednym znajdowały się także cztery łany, z czego był roczny dochód oraz zobowiązanie do pracy przy żniwach. Dawny proboszcz Jan Babeczki zostawił zapis 1000 florenów na magistracie w Gniewie, co dawało dochód przeznaczony na odprawianie mszy w każdy piątek o Męce Pańskiej. Meszne pobierano z wsi Pączewa i Wolental. Dom plebański wprawdzie niezbyt wygodny, zabudowania gospodarcze, ogród, pasieka i studnia - w dobrym stanie. Był też osobny browar. Był dom szkoły, w którym mieszkał organista uczący dzieci, mający należyte wynagrodzenie od parafian, a także łan ziemi dany niegdyś przez księcia Radziwiłła oraz prawo wolnego wypasu bydła. Przytułek nowo wystawiony przez zmarłego niedawno proboszcza Andrzeja Kitowskiego. Uposażenia własnego nie posiadał, jedynie z części, która można było wydzierżawić, mógł być pewien czynsz. Zasadniczo ubodzy żyli z jałmużny.

Proboszczem był Michał Oczyński, s. 220-221.

N o w a C e r k i e w. Wieś należąca do opata z Pelplina. Kościół parafialny, pw. św. Piotra i Pawła, którego prezbiterium było murowane, zaś nawa wystawiona z pruskiego muru. Opis stanu świątyni. Dosyć dobre wyposażenie w Paramenty liturgiczne.

Proboszcz miał cztery łany ziemi oraz dom z trzema łanami, na których siedzieli zagrodnicy pracujący na gruncie proboszcza. Meszne pobierał z wsi: Nowa

${ }^{55}$ Później dopisano inna ręką, że parafię tę włączono do dekanatu nowskiego. 
Cerkiew, Rozental, Getomie, Morzeszczyn, Rzeżęcin, Kulice. Z Borkowa, Rąbarku, Bielawek i folwarku Ropuchy proboszcz milka jedynie kolędę. Zabudowania plebańskie wszystkie nowe i w dobrym stanie. Po pożarze szkoły, przytułku i innych zabudowań plebańskich został wystawiony nowy dom, jeszcze nie ukończony z czterema pomieszczeniami. W jednym mieszka organista uczący dzieci i był dobrze wynagradzany.

Proboszczem był Jakub Rokicki, s. 21-223.

R a j k o w y. Wieś królewska w starostwie gniewskim. Kościół parafialny pw. św. Bartłomieja wystawiony z pruskiego muru. Opis świątyni. Na uposażenie kościoła były dwa kawałki ziemi, jeden nazywany Skrzypice, drugi zaś Smyczek oraz łąka zwana Parchaty Kat, Grunta te posiadał organista tytułem wynagrodzenia z parafii. Ponadto znajdowało się pięć domów, przynoszących dochód roczny. Wykaz paramentów kościelnych.

Proboszcz miał cztery łany. Meszne było jedynie z wsi Rajkowy. Zabudowania plebańskie powinny być wyremontowane przez mieszkańców wsi. W szkole mieszkał organista uczący dzieci. Wynagradzany wyżej wspomnianymi gruntami, pewnymi daninami od mieszkańców i wolnym wypasem bydła, s. 223-225.

S z p r u d o w o. Wieś królewska w starostwie gniewskim. Kościół parafialny, murowany, pw. Szymona i Judy Apostołów. Opis świątyni \{pewnie filialnej], bo nie przechowywano tu Najświętszego Sakramentu, nie było chrzcielnicy. Skromne wyposażenie w naczynia liturgiczne.

Nie było bliższych wiadomości o uposażeniu proboszcza, z wyjątkiem tego, że był mały domek dający roczny dochód. Do parafii należała jedynie wieś parafialna. Nie było domu dla nauczyciela, s. 225-226.

Li g n o w y. Wieś w dzierżawie Dönhoffów. Kościół parafialny, wspaniały i murowany, pw. św. Marcina. Opis świątyni. Na wyposażenie świątyni było dwadzieścia cztery morgi ziemi i łąk, ale oddano to w dzierżawę, co jednak nie przynosi dochodu, ze szkodą dla kościoła. Ponadto mały domek dzierżawiła niejaka Anna Pultinka. Według zapisu jednego z proboszczów z 1658 r., był pewien zapis, mający dawać roczny dochód. Wykaz naczyń liturgicznych.

Proboszcz miał cztery łany ziemi, łąkę o powierzchni 6 do 7 mórg położona pomiędzy łąkami Jerzego Wilma i Jana Rajkowskiego. Były też dwa domy dające dochód. Meszne pobierał z wsi: Lignowy, Bursztyn, Janiszewo. Zabudowania plebańskie wymagały naprawy. W szkole mieszkał organista. Przytułek zniszczony przez dwudziestoma laty, powinni odbudować parafianie.

Parafią administrował Bartłomiej Zieleniewski, 226-227.

G a r c z. Wieś królewska w starostwie gniewskim. Kościół parafialny murowany, ale nie znano wezwania. Opis świątyni. Na jej uposażenie było dwanaście mórg łąk w małych Walichnowach, ale mieszkańcy wsi Garcz zawłaszczyli je dla siebie. Z dwóch domków był pewien dochód. Wykaz paramentów liturgicznych.

Proboszcz posiadał cztery łany ziemi i dwanaście mórg łąk. Mieszkańcy po- 
szczególnych wiosek parafialnych mieli obowiązek dawania po wozie drewna na opał. Natomiast meszne pobierał z następujących wsi: Garcz, Rudno, Gremblin. Mieszkańcy tych wsi (kmiecie) byli luteranami, z wyjątkiem jednego z wsi Rudno. Zabudowania plebańskie stare i wymagały restauracji, do czego zobowiązani byli parafianie. Dla nauczyciela, który był też organistą, był dom z ogrodem . Pobierał tez wynagrodzenie od parafian.

Proboszczem był Maciej Kweys, kapelan ówczesnego ordynariusza włocławskiego, tu nie rezydujący, a w jego zastępstwie parafią administrował proboszcz z parafii Lignowy orarz zakonnik z klasztoru w Pelplinie, s. 228-229.

W a 1 i c h n o w y. Wieś królewska w starostwie gniewskim. Murowany kościół parafialny, pw. św. Jana Chrzciciela. Opis świątyni i skromnego wyposażenia w naczynia liturgiczne.

Na uposażenia proboszcza składały się trzy łany ziemi, ponadto dwadzieścia cztery morgi ziemi i łąki, zwane Lądy, cztery morgi ziemi przy Krzyżu, w kierunku wsi Gronówko, z czego płacono czynsz. Były jeszcze inne posiadłości i domy, tu wyliczone, dające proboszczowi dochód. Ponadto kmiecie mieli obowiązek dostarczenia zimą wozu drewna, zaprzęgniętego w cztery konie. Meszne zaś było pobierane z wsi Walichnowy Wielkie i Walichnowy Małe. Zabudowania plebańskie dobre. Szkoły nie było, Organista zamieszkiwał u rodziców [Zatem musiał pochodzić z tej wsi]. Był opłacany przez parafię.

Parafia administrował Marcin Schela, kanonik kruszwicki ${ }^{56}$, zawsze tu rezydujący, s. 230-231.

G n i e w. Miasto królewskie, ze świątynia murowaną, pw. św. Mikołaja. Dokładny opis świątyni. Były trzy domy, dające dochód na utrzymanie świątyni. Wykaz paramentów liturgicznych. Dwa bractwa. jedno różańcowe, założone za zgoda oficjała gdańskiego i kanonika włocławskiego [Teodora] Zaporskiego ${ }^{57}$ i drugie, św. Anny, z zezwolenia biskupa włocławskiego [Mikołaja] Gniewosza (1642-1654). Uposażenia własnego bractwa te nie posiadały, ale bractwo różańcowe miało własne paramenty liturgiczne.

Proboszcz, z tytułem prepozyta, posiadał cztery łany ziemi. Ponadto, jak to wynikało z przechowywanego dokumentu, było jeszcze dziewięć łanów, zwane Wierzyco, nadane przez księcia Albrechta Stanisława Radziwiłła, starostę malborskiego, jako wynagrodzenie za krzywdy, jakich doznała parafia od innowierców. Darowizna ta została potwierdzona przez króla Władysława [IV], dokumentem wystawionym w Warszawie, dnia 5 XI 1639 r., którego kopia tu została przytoczona. Meszne pobierano z wsi Gronowa, folwarku Ciepłe, Gronowo i Brody. Były jeszcze inne posiadłości proboszcza, dokładnie wyliczone. Z licznych domów, których użytkowników tu wyliczono, był dalszy dochód. Miał też prawo propinacji. Wyliczono też pretensje, czyli dezyderaty proboszcza pod adresem miasta. Opis zabudowań plebańskich, z których niektóre były nowe. W szkole,

${ }^{56}$ Biogram tego kanonika zob. A. F i u t a k, Prałaci i kanonicy kruszwiccy, s. 111 (mps w Archiwum Diecezjalnym we Włoclawku).

${ }^{57}$ Biogram tego archidiakona pomorskiego zob. C h o d y ń s k i, Katalog, s.1071-1075. 
posiadającej trzy mieszkania, mieszkał nauczyciel, organista i zakrystianin, wszyscy opłacani przez parafię. Organista miał jeszcze łan ziemi. Byli muzycy, mający przywilej monarszy śpiewania na ślubach w okręgu starostwa gniewskiego. Szpital znajdował się w murach miejskich, przy bramie zwanej Wodną. zamieszkiwało w nim ośmiu ubogich. Było własne uposażenie. Były słuszne pretensje parafii do terenu i własności zniszczonego kościoła szpitalnego św. Jerzego, s. 233-241.

T y m a w a, kościół filialny - podano uwagę, że będzie opisany później (na s, 246), s. 241.

P e 1 p 1 i n (kościół służący duszpasterstwu). Świątynia ta od czasów najdawniejszych służyła mieszkańcom Pelplina i sąsiednich, jak Ropuchy i Lipienki. Dawniej też swobodnie była wizytowana. Tym razem wizytator do wizytacji nie został dopuszczony przez opata, mógł jedynie odprawić mszę. Nie pomogło nawet podniosłe słowo wypowiedziane przez niego podczas mszy. Dlatego, gdy doniesiono o tym biskupowi włocławskiemu, Konstantemu Felicjanowi Szaniawskiemu, ten dnia 31 października, będąc w Subkowach na Pomorzu, wystawił dokument polecający dziekanowi gniewskiemu, proboszczowi z Piaseczna, przeprowadzić wizytacje tej świątyni, według przepisów soboru trydenckiego. Gdyby zaś przełożeni klasztory pelplińskiego sprzeciwili się temu, zagroził interdyktem na świątynię. Odpis tego postanowienia w całości tu przytoczono. Gdy po kilku tygodniach dziekan gniewski i proboszcz z Piaseczna, Andrzej Montowski, przybył na wizytację, umożliwiono mu ją przeprowadzić. Nie okazano jedynie metryki. Nakazano to uzupełnić, aby ten spór zakończyć, s. 242-243 ${ }^{a 58}$.

T y m a w a. Kościół we Wsi starostwa gniewskiego, zbudowany z pruskiego muru przez innowierców i przez nich użytkowany, w 1596 r., razem z kościołem w Gniewie, został odzyskany przez biskupa Rozrażewskiego. Konsekrowany przez sufragana żmudzkiego, dziekana włocławskiego i oficjała gdańskiego, Jacka Święcickiego ${ }^{59}$ w 1663 r., pw. św. Michała Archanioła.

Uposażenie proboszcza stanowiły cztery łany ziemi. Był jeszcze jeden łan, ale odłączono go do uposażenia parafii Gniew. Meszne płacono z wsi: Tymawa, gdzie wyliczono imiona i nazwiska płacących, Rakowiec, Bielawy, Jaźwiska, s. 243 ${ }^{\text {b }}$ $243^{\text {d. }}$.

\section{Wizytacja dekanatu świeckiego}

P r z y s i e r s k. Wieś królewska w starostwie świeckim. Drewniany kościół parafialny pw. św. Wawrzyńca. Opis świątyni. Wykaz dokładny wyposażenia w paramenty liturgiczne.

${ }^{58}$ Zaszła ty pomyłka w paginacji, ponieważ powtórzono numery stron os 243 , dlatego poprawiono je jako strony $243^{\mathrm{a}}$ do $243^{\mathrm{f}}$.

${ }^{59}$ Biogram tego oficjała gdańskiego i dziekana włocławskiego zob. C h o d y ń s k i, Katalog, s.899-901. 
Na uposażenie proboszcza składały się dwa łany ziemi, czynsz z jednego domu oraz meszne z wsi: Przysiersk, Konopat, Kawęczyn, Budin, Bukowiec, Drozdowo, Pniewno, Biechowko, Jarzębieniec. Zabudowania plebańskie domagały się odbudowy. Proboszcz miał osobny swój browar. Dla nauczyciela, który był jednocześnie organista i uczył dzieci, był domek osobny. Otrzymywał on wynagrodzenie z parafii oraz miał ponadto łan ziemi z nadania księcia Jabłonowskiego, ale dokumentu nie było. Był szpital, a w nim ubodzy, chociaż ich liczny nie podano, żyjący z jałmużny.

Proboszczem był Piotr Paweł Piechowski, s. 243f-245.

Ł ą k i e. Wieś zakonnic z Chełmna. Znajdował się tam kościół parafialny drewniany, pw. św. Bartłomieja. Opis świątyni. Wykaz paramentów liturgicznych.

Uposażenie proboszcza stanowiły dwa łany ziemi oraz meszne z wsi: Łąkie, Więckowo, Rozanno, Gołuszyce, Kkorytowo. Zabudowania plebańskie z drewna, na tak wygodne, s. 245-246.

G r u c z n o. Wieś kapituły gnieźnieńskiej z kościołem parafialnym, murowanym, pw. św. Jana Chrzciciela. Opis świątyni. Wykaz paramentów liturgicznych.

Bractwo Aniołów Stróżów, od dawna istniejące, nie mające własnych paramentów liturgicznych, ale zachowujące statuty.

Proboszcz miał uposażenie w dwa łany ziemi oraz trzeci z pół kmiecych, na co miał przywilej. Ponadto miał sześć domków, także przynoszących dochód. Meszne było z wsi: Gruczno, folwark Gruczno, osada młyńska Gruczno, Kossowo, Krostkowo, Luszkowo, Luszkówko, Małociechowo, Bagniewo, Parlino, Więckowo, Żurowo, Wiedziorek, Poledno, W Polednie dawniej był kościół filialny parafii Gruczno, pw. Wszystkich Świętych, mający na uposażenie cztery łany ziemi, ale dzierżawca Konopacki, kasztelan elbląski, innowierca, uposażenie to zawłaszczył. Dom plebański drewniany i zły, zabudowania gospodarcze dobre. Nauczyciel, który był jednocześnie organistą i uczył dzieci, miał domek, zaś wynagrodzenie pobierał z parafii. Ponadto miał małą włóczkę ziemi. Przytułek zniszczony, ale ubodzy w nim mieszkający żyją z jałmużny, bo własnego uposażenia nie było, s. 246248.

T o p o 1 n o. Wieś szlachecka Konarskich. Kościół parafialny, murowany, pw. Nawiedzenia Najświętszej Marii Panny i św. Józefa. Opis świątyni.

W parafii tej, obejmującej wsie" Topolno, Cieleszyno, Rutki i Grabowo, duszpasterstwo sprawują zakonnicy św. Pawła, Pierwszego Eremity, czyli paulini, s. 248-249.

$\mathrm{N}$ i e w i e ś c i n. Wieś szlachecka Niewieścińskich. Parafialny kościół, drewniany, był pw. Świętej Trójcy i św. Jakuba Większego Apostoła, ale znacznie zniszczony. Opis świątyni.

Wsie, z których proboszcz pobierał meszne: Niewieścin, Zębowo, Soponino, Cieleszynko, Zbrachlino, Wałdowo, Pruszcz, Mroczyn, Kozielec. Proboszcz miał 
codzienne utrzymanie we dworze, ponadto procent od zapisanych sum. Dom plebański nowy i murowany. Szkoła wraz z całą wsią, gdy nie można było zapłacić kontrybucji, zastała przez Szwedów spalona.

Parafią administrował zakonnik z Topolna, s. 249-250.

Ś w i e k a t o w o. Wieś kapituły włocławskiej. Kościół parafialny, drewniany, pw. św. Marcina. Opis świątyni, która na uposażenie swoje miała łan ziemi we wsi Korytowo, zapisany przez nieżyjących już Wisniowskich i Krupockich, obecnie w posiadaniu Franciszka Tuchołka, starosty jasieńskiego, który płaci czynsz. Wykaz paramentów kościelnych.

Proboszcz miał na uposażenie cztery łany ziemi, jeden domek w którym mieszkal zagrodnik, odrabiając mu pracą. Akcydens i meszne pobierał z wsi: Szewno, Branica, Krupocin, Ostrowite, Błądzim, Łąkie, osada młyńska Łąkie. Ponadto należały do parafii wsie kapitulne, Świekatowo i Zalesie. Dom plebański zły, zabudowania gospodarskie dobre. Szkoła, po spaleniu, nie została odbudowana, zaś organista mieszkał w domu parafialnym. Przytułek, stojący w środku wsi, w stanie dobrym i przebywało w nim trzech ubogich, żyjących z jałmużny.

Proboszczem był Antoni Czapiewski, s. 251-252.

L u b i e w o. Wieś arcybiskupa gnieźnieńskiego z drewnianym kościołem parafialnym pw. św. Mikołaja. Opis świątyni i paramentów liturgicznych.

Uposażenie proboszcza składało się z czterech łanów ziemi z łąkami oraz z akcydensów i mesznego z wsi: Lubiewo, Klonowo, Sucha, osady młyńskie Susen i Samszyńskie, Rozliny, Trutnowo. Wiernych do sakramentów wielkanocnych było 430 osób. Dom plebański drewniany dobry, zbudowany przed rokiem, zabudowania pozostałe także dobre. Nauczyciel mieszkał w domu parafialnym i był wynagradzany przez parafię ${ }^{60}$. W szpitalu mieszkało czterech ubogich, żyjących z samej jałmużny.

Proboszczem był dziekan świecki, niepodanego imienia Rutkiecki ${ }^{61}$, zawsze tu rezydujący, s. 252-254.

B y s $\nmid$ a w. Wieś królewska w starostwie tucholskim. Kościół parafialny, wystawiony z kamienia, pw. Wszystkich Świętych. Opis świątyni.

Proboszcz miał na uposażenie pięć łanów ziemi, prawo połowy ryb w jeziorach sąsiadujących z wsią, czynsze z budynków parafialnych i meszne z wsi: Bysław, Minikowo, Bysławek, Wełpin, Szumiąca, Piła, Zamrza i Ruda. Dom plebański i zabudowania gospodarcze wymagały naprawy. Czynsz z pięciu domów, ponadto jezioro, zwane Popówka, położone obok wielkiego jeziora należącego do dworu. Był domek dla nauczyciela, ale żadnego nauczyciela nie było, chociaż było dla niego uposażenie, s. 254-255.

C e k c y n. Wieś królewska w starostwie tucholskim, z kościołem drewnia-

\footnotetext{
${ }^{60}$ Później dopisano, że miał półwłóczek ziemi.

${ }^{61}$ Lekcja niepewna.
} 
nym z wieżą, pw. Świętego Krzyża. Opis świątyni. Do uposażenia kościoła należały trzy ogrody, zwane Kapuśniaczek, a także ofiary od pogrzebów, za dzwonienie i ofiary.

Proboszcz miał cztery łany ziemi z łąkami, oprócz domku, z którego czerpał dochód. Meszne pobierał z wsi: Czekcin, Suminy, Zamarte i Zalesie. Dom plebański mały i niewygodny, bez zabudowań gospodarczych. Były dwie łąki, jedna zwana Ostrów i druga o nazwie Babia Łąka. Szkoły nie było, ale pozostało uposażenie dla nauczyciela, s. 256-257.

Ś 1 i w i c e. Wieś królewska w starostwie świeckim. Znajdował się w niej kościół parafialny, drewniany, pw. św. Katarzyny. Opis wyglądu świątyni.

Uposażenie proboszcza stanowiły cztery łany ziemi, dwie łąki, jedna zwana Chmielnik, druga zaś Smug, ponieważ była zalesiona. Dwa domki dające dochód. Wsie parafialne oddające meszne: Śliwice, Łążk, Lińsk, Sliwiczki, Olewko. Dom plebański wymagający naprawy, zabudowań gospodarczych nie było. Był dom szkolny, ale nie wspomniano o nauczycielu, chociaż było dlań uposażenie, s. 257258.

O s i e. Wieś królewska w starostwie świeckim, z kościołem parafialnym drewnianym, pw. św. Bartłomieja, konsekrowanym przez sufragana włocławskiego Piotra Pawła Mieszkowskiego ${ }^{62}$. Opis świątyni.

Cztery łany ziemi z łąkami miał proboszcz, ponadto osobną łąkę wśród lasu, zwaną Księże. Dwa domki z gruntem, z czego był dochód i praca w czasie żniw. Natomiast meszne szło z wsi: Osie, Miedzno, Brzeziny, Wierzchy, osada młyńska Żur i osada młyńska Tleń6 ${ }^{6}$. Zabudowania plebańskie bardzo złe. Była szkoła, chociaż o nauczycielu nie wspomniano. Był fundusz na jego utrzymanie, s. 258259.

D r z y c i m. Wieś królewska w starostwie świeckim, w której znajduje się kościół parafialny, drewniany, pw. Wszystkich Świętych i Oczyszczenia Najświętszej Marii Panny. Opis świątyni. Z trzech domów kościół ma roczny dochód. Wykaz paramentów liturgicznych.

Proboszcz miał na swoje utrzymanie cztery łany ziemi. Ponadto cztery łany opuszczone, do folwarku Grodek należące, które posiada i zasiewa proboszcz, w zamian za opłatę, jaką powinien ponosić folwark. Na tych gruntach znajdowały się dwa domki bardzo zniszczone, ale zagrodnicy, jako wynagrodzenie, pracowali przy żniwach. Były jeszcze dwa inne domy, dające roczny dochód. Natomiast meszne pobierano z nastepujących wsi: Drzycim, Dulsk, Lubochenia, Gacko, Dąbrówka, Lubodziesz, Wetsie, Siemkowo, Lniano, Mszano, Brzemiona, Lnianko, Zalesie, Jastrzębie, Sierosław, Spławie, Wery, Rowienica, Świnolesie, Sierosławek, Grodek ${ }^{64}$. Dom plebański bardzo stary i wymagał naprawy. Inne zabudowania dobre. Dawna szkoła spaliła się i nie została odbudowana, ale nauczyciel

\footnotetext{
${ }^{62}$ Biogram tego biskupa zob. C h o d y ń s k i, Biskupi sufragani, s. 55-58.

${ }^{63} \mathrm{~W}$ tym miejscu znajduje się późniejszy dopisek o łące zwanej Dzierzązna i łące Zalesie.

${ }^{64} \mathrm{~W}$ tym miejscu późniejszy dopisek o łanach w Dzrycimiu i Gródku.
} 
mieszkał w małym domku i uczył dzieci, biorąc wynagrodzenia z parafii oraz za użytkowanie łanu ziemi. Przytułek, odbudowany po spaleniu się starego, ale jeszcze nie do końca. Ubodzy utrzymywali się z jałmużny.

Parafia administrował Jakub Ignacy Kraterski, rezydując na miejscu, s. 260262.

J e ż e w o. Wieś należąca do biskupa włocławskiego, z kościołem parafialnym murowanym, pw. Świętej Trójcy. Opis świątyni. Parafia posiadała las, w którym znajdowała się pasieka, dająca dochód kościołowi. Inne dochody były z ofiar. Wykaz paramentów liturgicznych.

Proboszcz miał cztery łany ziemi i dwa domki dające roczny dochód. Ponadto meszne z wsi: Jeżewo, Taszewo, Białe, Piskarki, Belno, Ostrowo, Lipna, Lipienko, Laskowice, Krąpniewicze, Buczek, Czersko, Jaszcz i Busno. Dom plebański nowy, pozostałe zabudowania wymagały naprawy. Nauczyciel miał domek i był opłacany przez parafię, a ponadto miał łan ziemi, nadany przez biskupa [Stanisława] Dąmbskiego, ale dokumentu na to w Konsystorzu nie wystawiono.

Parafią administrował Franciszek Jakub Glasius, rezydujący stale na miejscu, s. $262-264$.

Ś w i e c i e. Miasto królewskie w dzierżawie wojewody ruskiego. Kościół parafialny murowany i wspaniały, pw. św. Stanisława. Dokładny opis świątyni. Na jej utrzymanie były zapisane pewne sumy na roczny procent, dokładnie tu wyliczone. Wykaz paramentów liturgicznych.

Istniało tu bractwo literatów, inaczej nazywane bractwem Świętej Trójcy, zaaprobowane przez biskupa Macieja Łubieńskiego w 1638 r., posiadające własne uposażenie, nawet dla kapelana. Ponadto było jeszcze bractwo Świętego Różańca, założone przez dominikanów i zatwierdzone przez Sebastiana Grotkowskiego, oficjała włocławskiego w 1639 r. Specjalnego uposażenia własnego nie posiadało, korzystało jedynie z ofiar członków, z czego każdego roku się rozlicznało wobec dziekana, albo przynajmniej proboszcza. Wyliczono tu paramenta liturgiczne bractwa, ale czy chodziło o bractwo różańcowe jedynie, czy o obydwa, dokładnie nie wyjaśniono. Trzecim było bractwo św. Anny, założone z zezwoleniem arcybiskupa lwowskiego Dimitra Solikowskiego i zaaprobowane przez władze diecezjalną. Posiadało własne uposażenie i nieco paramentów liturgicznych. Ponadto były jeszcze bractwa rzemieślnicze, czyli cechy, opiekujące się poszczególnymi ołtarzami w kościele i zamawiającymi swoje nabożeństwa sprawowane przez proboszcza lub wikariusza.

Proboszcz miał na swoje uposażenie dwa łany ziemi z łąkami, ponadto jeszcze jedną łąkę położoną wśród łąk zwanych Pieprzowe. Były też liczne zapisy dające roczny procent, tu dokładnie wyliczone. Wsie, z których pobierano opłaty mesznego były następujące: Przechowo i folwark Przechowo, Przechówko, Kozlowqo i folwark Kozłowo, Skarszewy, Sulnowka, Sulnowo, Zdzikowy, Wiąg, Czaple, Czapelki, Marzy, Michale, Stwolno, Stwolenko, Morsk, osady młyńskie Przechowo, Kozłowo i Skroba, Święte Wielkie, Sartawice, Sartawiczki, , osada młyńska Święte. Zabudowania plebańskie wymagały naprawy. 
Był specjalny fundusz dla kaznodziei z sum lokowanych na procent, tu wykazanych. Kaznodzieją był zakonnik z zakonu bernardynów.

Dom dla wikariusza, osobny od plebanii, który powinien, razem z plebanią, zostać odnowiony. Aktualnie mieszkał tam stary kapłan Adam Dolecki, dawny proboszcz ze Świecia, który zrezygnował z parafii.

Była szkoła, wystawiona z pruskiego muru, bardzo zniszczona. Mieszka w niej dwóch wikariuszy, zakrystianin, który też uczył dzieci. Staranie o dom dla organisty powinno mieć miasto, a ten był opłacany częściowo przez parafię, częściowo przez mieszczan. Był jeszcze kantor, ale nie miał własnego mieszkania i był wynagradzany ze specjalnie na to zapisanych sum, wypłacanych mu przez proboszcza.

Przytułek większy, przy kościele, z dwoma pomieszczeniami i własnym uposażeniem z zapisanych funduszy, tu dokładnie wymienionych. Nie podano liczby ubogich, jacy mogli tam przebywać.

Przytułek drugi, zwany Chory Domek, z czterema ubogimi, także posiadający własne fundusze, tu wyliczone.

Przytułek trzeci, przy klasztorze bernardynów, także z własnym uposażeniem.

Każdy z tych przytułków miał prowizora, który rozliczał się przez magistratem, w obecności proboszcza.

Proboszczem był Walenty Czapski, kanonik poznański, rezydujący na miejscu i posiadający dwóch wikariuszy, a mianowicie Stanisława Porniewicza i Jakuba Ciechowskiego, s. 264-271.

Ś w i ę t e. Wieś szlachecka, której wszyscy mieszkańcy byli innowiercami. Był tu kościół, wystawiony z pruskiego muru, pw. św. Wojciecha. Krótki opis stanu świątyni. Dawniej było uposażenie dla proboszcza, ale teraz pozostał jedynie domek plebański. Powinno się założyć proces w Trybunbale o odzyskanie własności. Do tego kościoła należała jedna wieś parafialna, Święte.

$\mathrm{S}$ a r t o w i c e ${ }^{65}$. Wieś szlachecka z kościołem drewnianym, leząca na wyspie rzeki Wisła, według dawnych wizytacji, filialnym parafii Święte. Nosiła wezwanie św. Barbary. Opis tej świątyni. Uposażenie żadnego nie było. Dom plebański jednak dobry.

Dawniej był kościół we wsi Michale, mający zabudowania plebańskie i uposażenie. Teraz pozostał jedynie cmentarz.

Podobnie we wsi Stwolno była świątynia z uposażeniem, a teraz pozostał jedynie cmentarz, z wystawionym tam, przez proboszcza ze Świecia, krzyżem, s. 272.

S e r o c k. Wieś królewska w starostwie jasieńskim. Kościół parafialny, drewniany, pw. Wszystkich Świętych. Dokładny opis świątyni,

Bractwo różańcowe, zaprowadzone przez Andrzeja Sędkowskiego, przeora

${ }^{65}$ W tekście napisano „Sartawice”. 
chełmińskiego i Kandyda Zagorowskiego, przeora krakowskiego, za aprobatą Konsystorza [Foralnego] Bydgoskiego. Bractwo to posiadało własne fundusze i zachowywało swoje statuty.

Uposażenie proboszcza składało się z trzech łanów ziemi, dwóch domów dających dochód i własnego jeziora z łąkami przy nim. Meszne pobierano z wsi: Serock, Łowin, Łaszewo, Gołuszyce, Nieściszewo, Łowinek, Glinki i osady młyńskie Lipchorz i Chochołek. Dom plebański drewniany i niezbyt odpowiedni, zaś zabudowania gospodarcze dobre, a przy nich dwa ogrody. Dla nauczyciela był dom z ogrodem. Nauczyciel był częściowo opłacany przez bractwo, częściowo przez parafię oraz miał także nieco ziemi. Przytułek, stojący na cmentarzu, został wzniesiony przez Remigiusza Powalskiego, który też pozostawił dla niego zapis na dobrach Łaszewo, co zapisano w aktach ziemskich w Świeciu. Jednak, jak zapisano, ubodzy z samej jałmużny żyją, s. 272-274.

I n d e k s a lfabety c z n y parafi i z podaniem strony protokółu wizytacyjnego i strony zapisania dekretu reformacyjnego. Dekrety reformacyjne znajdują się w niniejszej księdze po skorowidzu alfabetycznym i posiadają podwójna numerację. Dawną, rozpoczynająca się od 1 do 151 oraz nową, stanowiącą kontynuację, a więc od 275 do425. Karty zajęte przez indeks nie posiadają numeracji, a jest ich sześć.

\section{Dekrety reformacyjne dla dekanatu mirachowskiego ${ }^{66}$}

Dla kościoła w S t ę ż y c y, z dnia 6 grudnia 1710 r., s. 1-3(275-277).

Dla kościoła w K o ś c i e r z y n i e (Berna), z dnia 9 grudnia 1710 r., s. 3-5(277$-279)$.

Dla kościoła w G r a b o w i e, z dnia12 grudnia 1710 r., s. 5-8(279-283).

Dla kościoła w L i p u s z u, z dnia 14 grudnia 1710 r., s. 8-9(282-283)

Dla kościoła w W i e 1 u, z dnia16 grudnia 1710 r., s. 9-10(283-284).

Dla kościoła w G o r ę c z y n i e, (nie podano daty), s. 10-11(284-285).

Dla kościoła w K i e ł p i n i e, z dnia 27 stycznia 1711 r., s. 11-12(285-286).

Dla kościoła w C h m i e $1 \mathrm{n}$ i e, z dnia 30 stycznia 1711 r., s. 12-13(286-287).

Dla kościoła w S i e r a k o w i c a c h, z dnia 1 lutego 1711 r., s. 13-14(287$-288)$

Dla kościoła w S tr z e p c z u i S i a n o w i e, z dnia 30 lutego 1711 r., s. 14-16 (288-290).

Dla kościoła w L u z i n o, z dnia 5 lutego 1711 r., s. 16-17(290-291)

\section{Dekrety reformacyjne dla dekanatu puckiego}

Dla kościoła w W e j h e r o w i e, z dnia 9 lutego 1711 r., s. 19-21(293-295).

Dla kościoła w G ó r z e, z dnia 9 lutego 1711, s. 21(295).

${ }^{66}$ Dekrety reformacyjne pisane inną ręką. 
Dla kościoła w R e d z i e, z dnia 11 lutego 1711 r., s. 22-23(296-297).

Dla kościoła w R u m i i, z dnia 11 Lutego 1711 r., s. 23-24(297-298).

Dla kościoła w O k s y w i u, z dnia 13 lutego 1711 r., s. 24-25(298-299).

Dla kościoła w C h y 1 o n i i, z dnia 13 lutego 1711 r., s. 25-26(299-300).

Dla kościoła w P u c k u, z dnia 15 lutego 1711 r., s. 26-27(300-301).

Dla kościoła we wsi Ł e b c z, S w a r z e w o i S t r z e $1 \mathrm{n}$ o, s.27-29(301$303)^{67}$.

Uwagi dotyczące urzędu d z i e k a ń s k i e g o, s. 29-30(303-304).

Dla kościoła w M e c h o w e j i S t a r z y n o, wystawiony w Mechowej, dnia19 lutego 1711 r., s, 30-32(304-306)

Dla kościoła w Ż a r n o w c u, s. 32-33(306-307).

\section{Dekrety reformacyjne dla dekanatu lęborskiego}

Dla kościoła w L ę b o r k u i innych, przyłączonych, a mianowicie w N o w e j

W si, G a r c z e g or z u, B r z e ź n i e [Lęborskim] i R o z ł a z i n o, s. 35-38(309-312).

Dla kościoła w B i a ł o g a r d z i e i Łe b i e n i u, z dnia 10 wrześ nia 1711 r.; s. $38-39(312-313)$.

\section{Dekrety reformacyjne dla dekanatu bytowskiego}

Dla kościoła w B r u s a ch i Le śn i e, s. 41-42(315-316).

Dla kościoła w B y tow i e, Ni e z a b y s z e w i e i Dą brów ce, s. 42-45 (316-319).

Dla kościoła w T u c ho m i u, s. 45-46(319-320).

Dla kościoła w U g o s z c z u, B or z y t u ch omi u, K ot k ow i e i Stu$\mathrm{d}$ z i e $\mathrm{n}$ i c a c h, z dnia 22 III 1711 r. wystawiony w Ugoszczu, s. 46-48 (320322 )

Dla kościoła w S u 1 ę c z y n i e, s. 48-50(322-324).

Dla kościoła w Pa r c h o w i e, s. 50-52(324-326.

\section{Dekrety reformacyjne dla dekanatu starogardzkiego}

Dla kościoła w S t a r og ar d z i e, J a błow i e i N o w e j W s i, wystawiony w Starogardzie, dnia 24 grudnia 1710 r., s. 53-55(327-329).

Dla kościoła w P o g u d k o w y c h i P i n c z y n i e, wystawiony w Pogutkowych, dnia 21 grudnia 1710 r., s. 55-57(329-331).

Dla kościoła w B o b o w i e i D ą b r ó w c e, wystawiony w Bobowie, s.5759(331-332).

${ }^{67}$ Nie podano tu daty wystawienia dekretu. W dalszej części też często tego nie czyniono. 
Dla kościoła w Z b 1 e w i e, wystawiony w Zblewie, dnia 8 marca 1711 r., s. 5860(332-334).

Dla kościoła w C z e r s k u i Łą g u, wystawiony w Czersku, dnia 10 marca 1711 r., s. 60-62(334-336).

Dla kościoła w K i s z e w i e i P o la s z k a c h, wystawiony w Kiszewie, s. 6263(336-337).

Dla kościoła w K o k o s z k o w a c h, wystawiony w Kokoszkowie, dnia 29 marca 1711 r., s. 63-64(337-338).

Dla kościoła w K l o n ó w k u, wystawiony w Klonówku, s. 64-65(338-339).

\section{Dekrety reformacyjne dla dekanatu tczewskiego}

Dla kościoła w R e k o w n i c y i A d a m o w i e, wystawiony w Adamowie, 26 marca 1711 r., s. 67-68 (341-342).

Dla kościoła w W y s i n i e i G a r c z y n i e, wystawiony w Wysinie, s. 68-69 (342-343).

Dla kościoła w M i ł o b ą d z u i D a l w i n i e, wystawiony w Miłobądzu, s. 69-70 (343-344).

Dla kościoła w G i e m 1 i c a c h, wystawiony w Giemlicach, dnia 24 kwietnia 1711 r., s. 70-72 (344-346.

Dla kościoła w T c z e w i e, s. 72-73 (346-347).

Dla kościoła w L u b i s z e w i e, wystawiony w Lubiszewie, dnia 28 kwietnia 1711 r., s. 73-74 (347-348.

Dla kościoła w S u b k o w a c h, s. 74-75 (348-349).

Dla kościoła w G o r z ę d z i e j u, wystawiony w Subkowach, dnia 26 kwietnia 1711 r., s. 76(350).

Dla kościoła w G o d z i s z e w i e, s. 76-77 (350-351).

Dla kościoła w O b o z i n i e, wystawiony w Godziszewie, dnia 2 maja 1711 r., s, 77-78 (351-352).

Dla kościoła $\mathrm{w}$ T r ą b k a c h, wystawiony w Trąbkach, dnia 4 maja $1711 \mathrm{r}$,, s. 78-79 (352-353).

Dla kościoła w S k a r s z e w a c h i S z c z o d r o w i e, wystawiony w Skarszewach, s. 79-80 (353-354).

\section{Dekrety reformacyjne dla dekanatu gdańskiego}

Dla kościoła w M i e r z e s z y n i e, wystawiony w Mierzeszynie, dnia 27 czerwca 1711 r., s. 81-82(355-356).

Dla kościoła w P r ę g o w i e i $\dot{Z}$ u 1 a w c e, wystawiony w Pręgowie, dnia 23 czerwca 1711 r., s. 82-83(356-357).

Dla kościoła w Ż u k o w i e, wystawiony w Żukowie, dnia 25 czerwca 1711 r., s. 83-84(357-358). 
Dla kościoła w K i e 1 n i e, Pr z o d k o w i e i w kaplicy S z e n w a 1 d $^{68}$, wystawiony w Kielnie, dnia 26 czerwca 1711 r., s. 84-86(358-360).

Dla kościoła w C h w a s z c z y n i e, z dnia 26 czerwca 1711 r., s. 86-87 (360$361)$.

Dla kościoła w M a t a r n i, Wystawiony w Matarni, dnia 28 czerwca 1711 r., s. 87-88(361-362).

Dla kościoła w O 1 i w i e, wystawiony w Oliwie, dnia 27 czerwca 1711 r., s. 88$-90(362-364)$.

Dla kościoła w G d a ń s k u - kaplicy królewskiej wystawionej przez Jana III [Sobieskiego], wystawiony w Gdańsku, dnia 30 czerwca 1711 r., s. 90-92 (364-366).

Dla kościoła w Ś w i ę t y m W o j c i e c h u pod Gdańskiem, wystawiony 2 lipca 1711 r., s. 92-93(366-367).

Dla kościoła w Ł ę g o w i e, wystawiony w Łęgowie, dnia 6 lipca 1771, s. 93-95 (367-369).

Dla kościoła w R ó ż y n a c h, , s. 95-96 (369-370).

Dla kościoła w K ł o d a w i e, wystawiony w Kłodawie, dnia 7 lipca 1771 r., s. 96-97 (370-371).

\section{Dekrety reformacyjne dekanatu gniewskiego}

Dla kościoła w P i a s e c z n i e, wystawiony w Piasecznie, dnia 4 października 1711 r., s. 99-101 (373-375).

Dla kościoła w $\mathrm{O}$ p a 1 e $\mathrm{n}$ i u ${ }^{69}$, wystawiony w Opaleniu, dnia 20 września 1711 r., s. 101-102 (375-376).

Dla kościoła w D z i e r ż ą ż n i e, wystawiony w Dzierżążnie, dnia 6 października 1711 r., s. 102-103 (376-377).

Dla kościoła w P ą c z e w i e i C z a r n y m l e s i e, wystawiony 7 października 1711 r., s. 103-104 (377-378).

Dla kościoła w N o w e j C e r kw i, s. 104-105 (378-379).

Dla kościoła w parafii K r ó 1 ó w 1 a s, z dnia 7 października 1711 r., s. 105-106 (379-380).

Dla kościoła w R a j k o w a c h, wystawiony w Rajkowach, dnia 15 października 1711 r., s. 106-107 (380-381).

Dla kościoła w Li g n o w a c h i S z p r u d o w i e, z dnia 19 listopada 1711 r., s. 107-108 (381-382).

Dla kościoła w parafii G a r c z, wystawiony w we wsi Garcz, dnia 21 listopada 1711 r., s. 108-110 (382-384).

Dla kościoła w W a 1 i c h n o w a c h, wystawiony w Walichnowach, dnia 23 listopada 1711 r., s. 110-111 (384-385).

${ }^{68}$ W tekście napisano"Svinvald".

${ }^{69} \mathrm{~W}$ protokółach wizytacyjnych ta parafia znajdowała się w dekanacie nowomiejski. Dlacvzego teraz w tym dekanacie, powiedzieć trudno. 
Dla kościoła w G n i e w i e i kaplicy w T y m a w i e, wystawiony w Gniewie, dnia 25 listopada 1711 r., s. 111 (385).

Dla kościoła w P e 1 p 1 i n i e - kościoła Bożego Ciała, służącego duszpasterstwu, wystawiony w sąsiednich Rajkowach, dnia 14 października 1711 r., s. 111-113 (385-387).

\section{Dekrety reformacyjne dekanatu nowomiejskiego}

Dla kościoła w L u b i e n i u, , wystawiony w Libieniu, dnia 28 sierpnia 1711 r., s. 115-116 (389-390).

Dla kościoła w K o m ó r s k u, s. 116-117 (390-391).

Dla kościoła w B z o w i e, z dnia 30 sierpnia 1711 r., s. 117-118 (391-392).

Dla kościoła w N o w e m, s. 118 (392).

Dla kościoła w P ł o c h o c i n i e, wystawiony w Nowem, dnia 2 września 1711 r., s. 118-120 (392-394).

Dla kościoła w P i e $\mathrm{n}$ i ą ż k o w i e, wystawiony w Pieniążkowie, dnia 3 września 1711 r., s. 120-122 (394-396).

Dla kościoła w L a 1 k o w y c h, z dnia 21 września 1711 r., s. 122-123 (396-397).

Dla kościoła we wsi J a n i a, z dnia 22 września 1711 r., s. 123-124 (397-398).

Dla kościoła w $\mathrm{B}$ a $\mathrm{r} \nmid \mathrm{o} \dot{\mathrm{z}} \mathrm{n}$ i $\mathrm{e}^{70}$, wystawiony w Barłożnie, dnia 7 września 1711 r., s. 124-125 (398-399).

Dla kościoła w S k ó r c z u i G r a b o w i e, z dnia 24 września 1711 r., s. 125$-129(399-403)$.

\section{Dekrety reformacyjne dekanatu świeckiego}

Dla kościoła w Pr z y s i e r s k u, wystawiony w Przysiersku, dnia 19 maja 1711 r., s 131 (405).

Dla kościoła w S w i e c i u, Ś w i ę t e m i w S a r t o w i c a c h, wystawiony w Świeciu, bez podania daty, s. 132-136 (406-410).

Dla kościoła we wsi Ł ą k i e, wystawiony w Łąkach, dnia 19 maja 1711 r., s. 136-137 (410-411).

Dla kościoła w T o p o $\ln$ i e, wystawiony w Topolnie, dnia 28 maja 1711 r., s. 136 (411).

Dla kościoła w $\mathrm{N}$ i e w i e ś c i n i e, wystawiony w Niewieścinie, dnia 30 maja 1711 r., s. 137-138 (411-412).

Dla kościoła w Ś w i e k a t o w i e, wystawiony w Świekatowie, dnia 31 maja 1711 r., s. 138-140 (412-414).

Dla kościoła w L u b i e w i e, wystawiony w Lubiewie, dnia 1 czerwca 1711 r., s. 140-141 (414-415). skim.

${ }^{70} \mathrm{~W}$ protokółach wizytacyjnych parafia w Barłożnie została wyliczona w dekanacie gniew- 
Dla kościoła w S e r o c k u, wystawiony w Serocku, dnia 18 maja 1711 r., s. 141$-144(415-418)$.

Dla kościoła w B y s ł a w i u i C e k c y n i e, z dnia 1 czerwca 1711 r., s. 144$-145(418-419)$.

Dla kościoła w Ś 1 i w i c a c h, wystawiony w Śliwicach, dnia 2 czerwca 1711 r., s. $145-147$ (419-421).

Dla kościoła we wsi O s i e, wystawiony we wsi Osie, dnia 2 czerwca 1711 r., s. $-147(421)$.

Dla kościoła w D r z y c i m i u, wystawiony w Drzycimiu, dnia 3 czerwca 1711 r., s. 148 (422).

Dla kościoła w J e ż e w i e, wystawiony w Jeżewie, dnia 4 czerwca 1711 r., s. $148-150(422-424)$

Dla kościoła w G r u c z n i e, s. 150-151 (424-425).

\section{G 40}

\section{A. OPIS KSIĘGI}

[1. Sygn. Akt.] G 40.

[2. Tytuł oryg.] Visistatio Nonnularum Ecclesiarum in Archidiaconatu Pomeraaniae sitarum, per Perillustrem olim Reverendissimum Josephum Ignatium Narzymski ${ }^{71}$, Archidiacinum Pomeraniae in anno 1728 peracta.

[3. Daty krańc.] 1728.

[4. Opis zewn.] Łac. $2^{0}(32,5 \times 20,5 \mathrm{~cm})$. Stron paginowanych cyframi arabskimi 204.Stan zachowania księgi dobry. Oprawa stara w skórę z tłoczeniami, ale bez żadnych napisów. Przed stroną 1 wklejona karta z indeksem parafii i dekanatów sporządzonym w języku niemieckim. Pismo drobne, ale czytelne kilku rąk. Strony puste: 44, 59-60, 76, 90-92, 96, 151, 152, 189, 190, 197-200.

Wszystko wskazuje na to, że protokóły sporządzali najczęściej sami proboszczowie (zob. s. 141, gdzie w pierwszej osobie pisze proboszcz parafii Kloców$\mathrm{ka})$.

[5. Uwagi]. Była to wizytacja generalna.

Księga składa się poniekąd z kilku części.

Część pierwsza to zapewne protokóły sporządzone zgodnie z zapowiedzią w tytule. Jednak od strony 13 zaczynają się już wpisy dekretów powizytacyjnych, pisanych tą samą ręką, co protokóły wizytacyjne. Nie relacjonowano w niniejszym repertorium ich treści, zostawiając to zainteresowanym

Osobna poniekąd część to protokół wizytacji parafii Tczew i inkorporowanej doń parafii Lubiszewo, sporządzony przez dziekana tczewskiego i proboszcza lubiszewskiego Jakuba Bernarda Król. Te dwa protokóły spisane już inną ręką, ale podpis wizytatora i świadków osobiste.

${ }^{71}$ Biogram tego prałata zob. C h o d y ń s k i, Katalog prałatów i kanoników włocławskich, s. $656-658$. 
Ostatnia część, rozpoczynająca się od strony 63, już przez innego pisarza sporządzona, ale bardzo staranie i dokładnie. Jednak nie stosowano tu podziału parafii według ich przynależności dekanalnej. Nie podając dat ich odbywania, trudno powiedzieć, czy kolejność zapisu w księdze jest rzeczywista kolejnością odbywania lustracji poszczególnych parafii. Przy niektórych parafiach bardzo dokładnie wyliczone wszystkie wioski. W niniejszym repertorium podawano ich brzmienie tak, jak zapisano w księdze. Podawano w zasadzie imiona i nazwiska nie tylko proboszczów, czy administratorów parafii, ale także wikariuszy, organistów, witrykusów i prowizoriów. Często przy wyliczaniu wsi są podawane ich powinności wobec proboszcza oraz właściciele. Nie było regułą podawanie ilości wiernych. Niekiedy określano, że chodzi o tych, którzy byli zdolni przystępować do sakramentów. Przy niektórych parafiach wspominano o liczbie nawróconych z innowierstwa. Można też wiele dowiedzieć się, jak wyglądała sprawowana w świątyniach parafialnych służba boża.

Wiele uwagi poświęcono problemowi uposażenia. Niekiedy rozróżniano dochody proboszcza od dochodów parafii. Nieraz brano to łącznie, lub wręcz mówiąc o uposażeniu parafii, miano na uwadze dochody proboszcza.

Niekiedy podawano też domowników plebanii, zwłaszcza wówczas, gdy była to matka proboszcza i osoby służące.

Trudno powiedzieć na ile słuszne jest przypuszczenie piszącego te słowa, że księga ta powstała z przepisania sprawozdań o stanie parafii przez poszczególnych proboszczów. Tylko to może wytłumaczyć tak znaczne różnice w sposobie sporządzania protokółów, chociaż były podany zestaw pytań, na który należało odpowiedzieć.

Nazwy miejscowości, poza nazwami parafii, pisanymi we współczesnym brzmieniu, podawano w takim brzmieniu, jak to było w księdze.

\section{B. ZAWARTOŚĆ KSIĘGI}

I n d e k s w języku niemieckim, karta wklejona nieliczbowana.

$\mathrm{K}$ a r t a t y tu ł o w a, z tytułem jak wyżej, także nieliczbowana.

W y k a z p y a ń stawianych proboszczom podczas wizytacji parafii, s. 1-3.

\section{Wizytacja dekanatu mirachowskiego}

B e r n a (Kościerzyna). Opis świątyni murowanej, inkorporowanej zakonnikom kartuzom, noszącej zapewne wezwanie dawnej świątyni, a więc św. Wojciecha i św. Jerzego, jeszcze nie konsekrowanej. Podano opis uposażenia parafii i wykaz dosyć bogatych paramentów liturgicznych. Istniało bractwo różańcowe posiadające swoje uposażenie. Były wota, zapewne przy ołtarzu brackim. Opis uposażenie proboszcza i wykaz miejscowości parafialnych oddających meszne dla proboszcza: zamek Kościerzyna, miasto Kościerzyna, Szynbark, Węglikowice, gdzie znajdowała się mała kaplica przy dworze, fundowana przez Węglikowskich, 
ale bez żadnego uposażenia, Klincz, Rekowmica, gdzie także był kościół, Bendomino Duże, Bendomino Małe, Pierzczewsko. Zabudowania plebańskie i przytułek dla ubogich, aktualnie spalony, ale posiadający własne uposażenie. Kaplica, zapewne szpitalna, drewniana, położona poza miastem, znacznie zniszczona, ale były fundusze na jej odnowienie, czy odbudowę. Nie wspomniano imienia proboszcza, s. 3-5.

S t e ż y c a. Świątynia zbudowana, ale jeszcze nie ukończona, przez aktualnego proboszcza i jej krotki opis.. Wykaz wyposażenia w parlamenty liturgiczne. Był przywilej odpustowy z racji święta św. Jana Chrzciciela. Bractwo Różańcowe i Najświętszego Imienia Jezus. Wsie parafialne oddające meszne: Stężyca Szlachecka, Stężyła Królewska, Huta Kamieniecka. Uposażenie proboszcza, stan zabudowań plebańskich, szkoły i przytułku. Proboszcz Jakub Alrhutt (Alshutt), od 1690 r., s. 5-6.

W e j h e r o w o (w dekanacie puckim). Podano wiadomość, że miasto zostało założone przez Wejhera, wojewodę malborskiego. Świątynia fundowana przez założyciela miasta, jednak dokument erekcyjny podobno znajdował się u zakonników franciszkanów, mających tu klasztor. Powinni go zwrócić kościołowi parafialnemu. Opis świątyni, jej uposażenie i wyposażenia. Uposażenie proboszcza i zabudowania plebańskie. Wiernych było około 600 osób. Przytułek był, ale wymagał pilnego remontu, a był wystarczająco uposażony w zapis Katarzyny Leszczyńskiej, zabezpieczony na dobrach Bolschau. Proboszczem był Franciszek Ruthen (Ruthensis), s. 6-8.

S k a r s z e w y. Opis murowanego kościoła parafialnego w mieście królewskim Skarszewy, pw. św. Michała Archanioła. Wykaz paramentów liturgicznych. Bractwo św. Anny. Uposażenie proboszcza, którego wielkość została przez proboszcza skarszewskiego i kanonika włocławskiego Jana Jugowskiego ${ }^{72}$ zapisana w aktach grodu skarszewskiego, s. 8-10.

$\mathrm{S}$ t a r o g a r d. W tym miesicie królewskim był parafialny kościół murowany pw. Św. Mateusza Apostoła i Ewangelisty, niedawno naprawiany przez Jakuba Rolickiego, ówczesnego wikariusza starogardzkiego, a obecnego proboszcza w Nowejcerkwi. Opis świątyni, jej uposażenia i w wyposażenia w naczynia liturgiczne. Bractwo Różańcowe, mające dokument założenia z 1666 r. oraz własne paramenta liturgiczne. Opis uposażenia proboszcza, zabudowań plebańskich, szkoły i przytułku. Dziesięciny, czyli meszne pobierał proboszcz z wsi: Rokoczyn, Owidz, Barchanowy, Klincz, Kocborowo. Katolików w tej parafii było 600 osób. Proboszczem był Franciszek Chmielewski, który utrzymywał tu stale rezydującego wikariusza Tomasza Machowskiego, s. 10-11.

${ }^{72}$ Biogram tego kanonika włocławskiego i archidiakona pomorskiego zob. C h o d y ń s k i, Katalog, s. 346, 348-350. 
C h m i e $1 \mathrm{n}$ o. Wieś zakonnic z Żukowa, z kościołem parafialny, drewnianym, pw. Św. Piotra i Pawła, tu opisanym. Wyposażenie w paramenty liturgiczne. Uposażenie proboszcza i zabudowania plebańskie, Proboszczem był od lat 10 Mikołaj $\mathrm{Kręcki}^{73}$. Podano dosyć szczegółowy spis inwentarza gospodarczego., s. 11-12.

\section{Dekrety reformacyjne z wizytacji generalnej dekanatu lęborskiego}

Dla parafii w L ę b o r ku, s. 13-14.

Dla parafii w B i ałog ardzi e i Łe bi en i u, s. 14.

\section{Dekrety reformacyjne $\mathrm{z}$ wizytacji generalnej dekanatu mirachowskiego}

Dla kościoła w S t e ż y c y, s. 14-15

Dla kościoła w B e r n a (Kościerzynie), s. 15.

Dla kościoła w Grabowie, s. 15-16.

Dla kościoła w L i p u s z u, s. 16.

Dla kościoła w W i e 1 u, s. 16.

Dla kościoła w C h m i e $1 \mathrm{n}$ i e, s. 16-17.

Dla kościoła w Sierakowicach, s. 17.

Dla kościoła w L u z i n o, s. 17.

\section{Dekrety reformacyjne $\mathrm{z}$ wizytacji generalnej dekanatu puckiego}

Dla kościoła w W e j h e r o w i e, s. 17-18.

Dla kościoła w O k s y w i u, s. 18.

Dla kościoła w Ł e b c z u, S w a r z e w i e i S tr z e ln i e, s. 18-19.

U w a g a dla dziekana, że powinien jak najprędzej odbyć wizytacje i zwołać kongregacje dekanalną, s. 19.

Dla kościoła w M e c h o w e j, s. 19.

\section{Dekrety reformacyjne z wizytacji generalnej dekanatu bytowskiego}

Dla kościoła w B r u s a c h, s. 19.

Dla kościoła w B y t o w i e, Ni e z a b y s z e w i e i D ą b r ó w c e, s. 19-20.

Dla kościoła w P a r c h o w i e, s. 20.

${ }^{73}$ Wiadomość ta jest nieścisła, jeżeli w poprzedniej wizytacji została tak samo podana. Zdaje się, że nieraz przepisywano wiadomości z dawniejszych wizytacji. 
Dekrety reformacyjne z wizytacji generalnej dekanatu starogardzkiego

Dla kościoła w S t a r o g a r d z i e, N o w e j W s i i J a bło w i e, s. 20-21. Dla kościoła w P o g u t k o w y c h i P i n c z y n i e, s. 21.

Dla kościoła w Z b 1 e w i e, s. 21.

Dla kościoła w K 1 o n ó w k u, s. 21.

\section{Dekrety reformacyjne z wizytacji generalnej dekanatu tczewskiego}

Dla kościoła w M i 1 o b ą d z u i D a 1 w i n i e, s. 21.

Dla kościoła w G i e m 1 i c a c h, s. 21-22.

Dla kościoła w S u b k o w a c h, s. 22.

Dla kościoła w T r ą b k a c h, s. 22.

Dekrety reformacyjne z wizytacji generalnej dekanatu gdańskiego

Dla kościoła w M i e r z e s z y n i e, s. 22.

Dla kościoła w Ż u k o w i e, s. 22-23.

Dla kościoła w K i e l n i e, Pr z o d k o w i e i kaplicy S z e n w a ld (Silwaldrensis), s. 23.

Dla kościoła w $\mathrm{M}$ a t a r n i, s. 23.

Dla kościoła parafialnego w O li w i e, s. 23-24.

Dla kościoła w Ś w i ę t y m W o j c i e c h u pod Gdańskiem, s. 24.

Dla kościoła w R ó ż y n a c h, s. 24-25.

\section{Dekrety reformacyjne z wizytacji generalnej dekanatu gniewskiego}

Dla kościoła w P i a s e c z n i e, s. 25.

Dla kościoła w D i e r ż ą ż n i e, s. 25.

Dla kościoła w P ą c z e w i e i C z a rn y m 1 e s i e, s. 25.

Dla kościoła w N o w e j C e r k w i, s. 25.

Dla kościoła służącego duszpasterstwu w P e 1 p 1 i n i e, s. 25-26.

Dekrety reformacyjne $\mathrm{z}$ wizytacji generalnej dekanatu nowomiejskiego

Dla kościoła w N o w e m, s. 26.

Dla kościoła w P i e n i ą ż k o w i e, s. 26-27.

\section{Dekrety reformacyjne z wizytacji generalnej dekanatu świeckiego}

Dla kościoła w P r z y s i e r s k u, s, 27. 
Dla kościoła w T o p o $1 \mathrm{n}$ i e, s. 27.

Dla kościoła w L u b i e w i e, s. 27.

Dla kościoła w S e r o c k u, s. 27.

Dla kościoła w Ś 1 i w i c a c h, s. 27.

Dla kościoła w O s i a c h, s. 27-28.

Dla kościoła w D r z y c i m i u, s. 28.

Dla kościoła w G r u c z n i e, s. 28.

Opis stanu kościoła i beneficjum w T c z e w i $\mathrm{e}^{74}$

Tczew, miasto królewskie, wraz z całym starostwem zostało włączone do ekonomii malborskiej. Bardzo dokładny opis kościoła murowanego, a mianowicie stan przechowywania Najświętszego Sakramentu, chrzcielnicy i Olejów świętych. Świątynia posiadająca prezbiterium i nawę główną, fundowana w $1226 \mathrm{r}$. przez książąt pomorskich, pw. Podwyższenia Świętego Krzyża i mająca za patrona św. Mikołaja. Dokładny opis świątyni, posiadającej siedem kaplic: św. Jana Chrzciciela, Anioła Stróża pod opieką takiegoż bractwa, Przemienienia Pańskiego, Trzech Króli, Apostołów Piotra i Pawła, św. Mikołaja i św. Jakuba Większego. Podano więcej szczegółów, co do uposażenia kaplic i jakie cechy, czy bractwa nimi się opiekują. Opis dosyć dokładny dzwonów z podaniem ich wielkości i napisów na nich, s. 29-31.

Wyliczono kolejno ołtarze i ważniejsze obrazy. Wykaz paramentów liturgicznych, najpierw naczyń srebrnych i innych, a następnie pozostałych. Wykaz inwentarza bractwea Aniołów Stróżów, s. 31-36.

Uposażenie kościoła i liczne nań zapisy, s. 36-37.

Porządek nabożeństw w kościele tczewskim. Do sakramentów z miasta przystępowało około 400 osób, zaś z wiosek 310 osób. Wykaz przywilejów odpustowych, s. 37-38.

Dochody i uposażenie proboszcza, któremu przysługiwał tytuł prepozyta, s. 39.

Wsie parafialne: Ciżykowo, Knybawa, Bałdowo, Czarlin, Rokitki, Suchostrzygi, Stembark, Sliwino, s.39-40.

Opis zabudowań plebańskich, s. 40-41.

Uposażenie organisty, którym aktualnie był niejaki Jakub Makowiecki oraz dochód stróża kościelnego, będącego także grabarzem. 41-42.

Wizytacja przeprowadzona i podpisana osobiście dnia 1 marca 1729 r. przez Jakuba Bernarda Króla, dziekana tczewskiego i proboszcza Lubiszewskiego, podpisanatakżeprzezwikariuszaJózefaMaukowskiego,zakonnikadominikaninazkonwentu tczewskiego, witrykusów Daniela Orsiniusa i Michała z Fehr, mieszczan oraz prowizorów Sobotkę i Lukaszewskiego, także mieszczan, s. $42-43^{75}$.

\footnotetext{
${ }^{74}$ Inną ręka dopisano datę 14 kwietnia. Może to data wizytacji?

${ }^{75}$ Ten protokół wizytacyjny robi wrażenie, jakby był wzorcowy dla następnych, w których te elementy się powtarzają.
} 
Opis stanu kościoła i beneficjum w L u b i s z e w i e, afiliowanego do parafii tczewskiej $^{76}$

Wieś w starostwie tczewskim. Świątynia murowana pw. Świętej Trójcy, zaś drugorzędnym świętem patronalnym była uroczystość Wniebowzięcia Najświętszej Marii Panny. Opis stanu tabernakulum, chrzcielnicy i Olejów Świętych. Stan świątyni i ołtarzy Wykaz dokładny wszelkich paramentów kościelnych, krucyfiksów,obrazówiksiąg. Wykazparamentów bractwaOpatrznościBoskiej,którew 1722 r. otrzymało potwierdzenie papieskie, zaś w 1723 biskupa Krzysztofa Antoniego Szembeka, biskupa włocławskiego pomorskiego s. 45-51.

Uposażenie kościoła i zapisy dla niego. Opis nabożeństw, s. 51-52.

Uposażenie proboszcza lubiszewskiego i zabudowania plebańskie, s. 53-54.

Wsie parafialne: Lubiszewo, Swarozyno, Goszyn. Liniewko, Wętkowy, Małżewo Wielkie, Małżewko, Rukoszyn, Stanisławie, s. 55-56.

Inwentarz gospodarski proboszcza. Wspomniano o poprzednim proboszczu Tomaszu Stanisławie Długońskim, s. 56-57.

Dochód organisty lubiszewskiego. Był nim Bartłomiej Kitowski, liczący lat około 30 i dobrze przygotowany do spełnianych obowiązków, s. 57-58.

Protokół podpisał własnoręcznie dziekan tczewski i proboszcz lubiszewski Jakub Bernard Król oraz wikariusz Józef Radziszewski, witrykusi Jerzy Rutka, sołtys i Jakub Gala z Lubiszewa oraz prowizorzy Michał Manikowski i Jerzy Eliaszyk.Luteranamibyłozaledwiekilkaosób, amianowiciedwóchmłynarzyitrzech pasterzy, s. 58.

M i ł o b ą d z. Wieś biskupa włocławskiego. Opis stanu świątyni, przechowywania Najświętszego Sakramentu, chrzcielnicy i Olejów Świętych. Wykaz wszystkich paramentów i ksiąg liturgicznych oraz porządek nabożeństw. Uposażenie kościoła i proboszcza. Przytoczono tu przywilej dany przez biskupa Macieja Łubieńskiego i Mikołaja Wojciecha Gniewosza odnoszący się do uposażenia proboszcza. Stan zabudowań parafialnych.

Parafią administrował Jan Kitowski, kanonik kruszwicki ${ }^{77}$ i dziekan gdański, najczęściej w Gdańsku przebywający. W parafii rezydował wikariusz Michał Rijmanowski. Organistą był Marcin Kordecki. Witrykusi sołtys z Miłobadza i z Kolinek niejaki Jagielski.

Wsie parafialne: Milobądz, Zajączkowo, Szpegawa Dabrówka, Mieszyn. Łukocin, Malewin, Żenisławki, Kobiekcz, Pszczólki, Kolink. Katolików było 976 osób, zaś luteran 242 osoby.

Bractwo różańcowe w parafii istniejące, nie posiadało własnego uposażenia, s. 63-67.

D a 1 w i n. Wieś królewska z kościołem drewnianym, filialnym parafii w Miłobądzu, pw. św. Mikołaja. Opis świątyni, w której odprawiano w co trzecią nie-

\footnotetext{
${ }^{76}$ Inna ręką dopisano datę 13 kwietnia.

${ }^{77}$ Biogram tego prałata zob. F i u t a k, Prałaci i kanonicy kruszwicy, s. 45-45v.
} 
dzielę. Do parafii należała jedynie wieś Dalwin. Administrował nią proboszcz z Miłobądza, s. 68.

S k a r s z e w y. Miasto królewskie. Murowany kościół parafialny, pw. św. Michała Archanioła, spalony w 1714 r., częściowo odbudowany. Opis świątyni, jej wyposażenia i nabożeństw. Uposażenie kościoła i proboszcza. Parafią zarządzał Jan Lewiński, kanclerz kruszwicki ${ }^{78}$. Wikariuszem był Jerzy Milskier, od lat 7. Witrykusami byli Kalicki i Paweł Szymanczyk. Organista Paweł Otto, który uczył czworo chłopców. Wsie parafialne: Nigut, Dęblin, Mirowo, Piece Kamirowskie, Czarnocin, Czarnocińskie Piece, Willa Nova Praeposituralis, Szczodrowo, Młyn Szczodrowski, dwie Nowe Kolonie, Wilki, Nowy Wiecc, Barhuta, Górne Piekło, Czashuta, Suchahuta, Świniebudy, Max, Pruska Karczma, Pawłowo, Pawłówko, Szklannahuta, Bombard, Celmerostwo, Krawusino, Białachowo. Wiernych było około 800 osób. Akatolików duża ilość i mieli swojego predykanta, s. 69-72.

S z c z o d r o w o. Wieś w starostwie szczodrowskim, z kościołem drewnianym, pw. św. Szymona i Judy Apostołów. Opis świątyni i wyposażenia. Opis uposażenia zawarty w wizytacji parafii skarszewskiej. [Parafią opiekował się proboszcz ze Skarszew], s. 73.

W y s i $\mathrm{n}^{79}$. Wieś biskupa włocławskiego. Opis drewnianego kościoła i jego wyposażenia. Uposażenie kościoła i proboszcza. Parafia administrowana przez Jerzego Gruntmana, liczącego lat 78, będącego tu już lat dwadzieścia. Witrykusi Adam Grąbczewski, Marcin Tesarz i Piotr Pustka. Organista Adam Pławski. Wsie parafialne: Wisiano, Wiecc Stary, Iłownica, Skrzydłówko, Skrzydłowo, Szarpaty, Szumlis, Trzepowo, Łąki, Piekło Dolne, Rymanowiec. Katolików było 408, luteran około 100, s. 74-75.

G o d z i s z e w o. Wieś opata z Lądu. Prezbiterium kościoła murowane, nawa natomiast z pruskiego muru. Opis świątyni będącej pw. św. Apostołów Piotra i Pawła, z dokładnym wyliczeniem ołtarzy, wyposażenia, a także z podaniem nabożeństw, sprawowanych przez dwóch zakonników cystersów z Lądu. Byli to Edmund Wierzbiński i Alfons Boerusch, profesi z klasztoru w Lądzie. Organista Michał Nieroławski i witrykusi Bartłomiej Rada i Stefan Szczepański.

Wykaz uposażenia kościoła i inwentarza.

Wsie parafialne, których było 15: Boruszewo Małe i Duże, Scinsk, Obozino, Gołębiewko, Gołębiewo Srodkowe, Gołębiewo Duże, Kosciszewo Duże, Kosciszewko, Kobierzyno, Szczerbięcin, Turze Duże, Turze Małe, Damaszka, Zygowice, Godziszewo. Ponadto były nowe małe kolonie: Folwark Bujary należący do Scinska, Szwagrowice należący do Gołębiewa Środkowego, Jastrzębie, Janowo,

\footnotetext{
${ }^{78}$ Biogram tego prałata zob. F i u t a k, Prałaci i kanonicy kruszwicy, s. 57.

${ }^{79}$ W tekście napisano „Wisino”.
} 
Kaźmierowo należące do Obozina. Katolików naliczono 739, nawróconych za pobytu aktualnego proboszcza 8 , luteran 80 , s. 77-81.

O b o z i n. Wieś szlachecka. Świątynia murowana, filialna Godziszewa. Opis wyposażenia. Utrzymywana jest przez dziedziców miejscowych. Nabożeństwa stosownie do życzenia dziedzica sprawowane przez rezydujących w Godziszewie zakonników, ponieważ była tu mała ilość wiernych. Jednak z racji święta św. Michała przybywało tu dużo wiernych i było nabożeństwo z kazaniem. Uposażenie, należne parafii w postaci dwóch łanów, użytkował dziedzic, dając roczny czynsz 20 florenów, s. 81-82.

$\mathrm{S} \mathrm{u} \mathrm{b} \mathrm{k} \mathrm{o} \mathrm{w} \mathrm{y} \mathrm{y}^{80}$. Wieś biskupa włocławskiego. Murowany i solidny kościół parafialny pw. św. Stanisława Biskupa i Męczennika. Opis jego dobrego wyposażenia i nabożeństw. Uposażenie parafii, podane wg wsi należących: Sobkowy, Wacmierz, Czarlin, Wacmirek, Gorzędziej, Brzezno, Słońca Wielka. Dalej podano należne uposażenie w innych wsi, leżacych poza parafią.

Rektorem kościoła był Tomasz Jan Machowski rodem z Pomorza, lat 50 liczący. Wikariusz Bartłomiej Pelkowski, lat 56. Organista i nauczyciel był, ale nie podano nazwiska, chociaż opisano jego uposażenie. Szpital niedawno zbudowany z trzema podopiecznymi żyjącymi z jałmużny. Witrykusi Marcin Nejman i Maciej Nejman.

W parafii zostało założone bractwo różańcowe, Najświętszego Imienia Jezus i Matki Boskiej, uposażone przez Kazimierza Gralewskiego na wsi Wacmierek. Był też na ten cel zapis 200 (pewnie florenów) przez niepodanego imienia Dalamińskiego zabezpieczone na zamku w Tczewie. Bractwa te opiekowały się własnymi ołtarzami i posiadały własne paramenty liturgiczne. Były też srebrne wota. Dokumenty erekcji bractwa znajdowały się w archiwum sobkowskim, s. 83-87.

G o r z ę d z i e j. Wieś królewska w starostwie tczewskim. Kościół pw. św. Wojciecha, posiadał prezbiterium murowane, zaś nawę stawiana w pruski mur. Opis świątyni i nabożeństw, które były w co trzecią niedzielę, na św. Wojciecha, św. Barbarę i w trzeci dzień Wielkanocy, Zielonych Świąt i Bożego Narodzenia, bo parafią administrował proboszcz z Subkowych. Bractwo w tej parafii zostało afiliowane do bractw w Subkowach, chociaż tu także posiadało własne paramenty, s. 88-89.

G a r c z y n. Wieś, dawniej Garczyńskich, obecnie zaś Bemów, innowierców. Świątynia częściowo murowana, częściowo wystawiona w pruski mur. Opis stanu świątyni i jej wyposażenia i uposażenia oraz nabożeństw. Parafią administrowal Józef Slomiński od 5 sierpnia 1727 r. Witrykusi Ludwik Olganowski, Michał Bruszk i Andrzej Sobek. Organista Franciszek Pniewski.

Wsie parafialne: Garczyn, Krotowo, Równe. Orle, Soboncz, Liniewo, Liniew-

${ }^{80} \mathrm{~W}$ tekście podano „Sobkowy”. 
ko, Lubieszyn, Płachty, Harnikowe Małe i Duże, Rokostowo. Katolików było 345, luteran 245, za aktualnego proboszcza nawróciła się jedna osoba, s. 93-95.

R e k o w n i c a ${ }^{81}$. Wieś szlachecka z Gleysen Dörengowskich. Kościół drewniany, pw. św. Michała Archanioła, z podaniem jego opisu i skromnego wyposażenia. Od dawna nie posiadała własnego proboszcza. Naprawiana przez dziedzica. Do parafii należała wieś Rekownica, Bendomin i Bendominek. Kolator obiecał odbudować dom dla proboszcza. Niepodano, kto administrował parafią, s. 97.

$\mathrm{N}$ i e d a m o w o ${ }^{82}$. Wieś szlachecka Jana Klińskiego, z kościołem drewnianym, częściowo już zniszczonym, pw. św. Mikołaja. Opis świątyni i jej wyposażenia, dosyć bogatego. Jednakże aktualnie nie było stałego proboszcza z winy kolatora. Właściwie do parafii należała wieś Niedomowo, wieś Luboń została od niej odłączona, dalej Stawiska, Polesie Małe i Polesie Wielkie. Nie była wiadoma liczba wiernych, s. 98-100.

P o g ó d k i ${ }^{83}$. Wieś opata Oliwskiego ze świątynią murowaną, fundowana przez bpa Tomasza Franciszka Czapskiego ${ }^{84}$, sufragana chełmińskiego i opata pelplińskiego w 1715 r. Dokładny opis świątyni i jej wyposażenia we wszelkie paramenta liturgiczne. Sposób sprawowania służby bożej. Uposażenie kościoła. Inwentarz paramentów liturgicznych należących do konfraternii Anioła Stróża. Inwentarz i dochody proboszcza. Dziesięciny proboszcz pobierał z wsi: Kleszczewo, Jaroszewy, Głodowo, Więckowy, Komin, Junkrowy, Czernikowy, Malikowy, Malarek, Wałdowko, Bara, Jezierce i Deka. Wiernych było 803 osoby, nawróconych za aktualnego proboszcza 50 osób, zaś luteran nieco ponad 230 osób. Organistą był Andrzej Wąsalski, witrykusami Piotr Cilkowski, Michał Tysarczyk i Jan Nierzwicki. Proboszczem zaś był Michał Lapczyński, który protokół wizytacji podpisał 15 stycznia 1729 r., s. 101-108.

$\mathrm{J}$ a b ło w o. Wieś królewska z murowanym kościołem parafialnym pw. św. Wawrzyńca, dokładnie opisanym tak co do stanu, jak i wyposażenia. Nabożeństwa odbywały się wg. P rzyjętego porządku, Do parafii należała jedynie wieś Jabłowo. Nie podano imienia i nazwiska aktualnego proboszcza, jedynie wspomniano o nieżyjącym już dawniejszym proboszczu Józefie Plumbowskim. Witrykusami byli Marcin Klosa i Tomasz Schultz, s. 109-111 ${ }^{85}$.

K o k o s z k o w y. Wieś królewska ze świątynią drewnianą, pw. św. Barbary. Dokładny opis tak świątyni, jak i jej wyposażenia. Porządek nabożeństw. Uposażenie kościoła. Organistą był Mateusz Pioszkowski, zaś witrykusem Mikołaj Le-

${ }^{81}$ W tekście podano „Rakownica”

${ }^{82}$ W tekście napisano „Niedamowy”.

${ }^{83}$ W tekście napisano „Pogutkowy”,

${ }^{84}$ Biogram tego biskupa zob. P. N i t e c k i, Biskupi Kościoła w Polsce w latach 965-1999, Warszawa 2000, s. 62.

${ }^{85}$ Protokół zdaje się być niedokończony, ponieważ pozostawiono połowę strony pustej. 
woczewicz. Do parafii należały wsie: Kokoszkowy, Żabno, Krąg z młynem, Bączek, czyli Orzechówka, Linowiec, Ciecholewy, Zduny, Szpegawsk i opuszczone osady Okole, Grobowiec i mały Baczek. Katolików przystępujących do sakramentów było około 500 osób, luteran natomiast około 100. Zarządca parafii był zakonnik dominikanin, Paulin Czapiewski, s. 111-113.

$\mathrm{Z}$ b 1 e w o. Wieś królewska należąca do starostwa borzechowskiego z kościołem murowanym, pw. św. Michała Archanioła, dokładnie opisanym, także pod względem wyposażenia we wszelki sprzęt liturgiczny i inny. Porządek nabożeństw. Uposażenie kościoła i proboszcza, z wyliczeniem inwentarza. Wyliczono następujące wsie parafialne z podaniem ich właścicieli, czy mieszkańców: Zblewo, Borzechowo (siedziba starostwa), Jeżewo, Bytonia, Radziejewo, Nieradowo, nowe kolonie Młyńsk, Czubek, Libiki, Jerzyki, Czarne, Wieleń, Zawada, Białachowo, Piekielko Nieradówko, Blumweld, Kazub, Dunajek Zamrze, Lipska Piła, Lipska karczma, Lipe, Kaliska, s. 114-120 $0^{86}$.

B o b o w o, Wieś będąca kluczem dóbr starostwa gniewskiego. Świątynia murowana, pw. św. Wojciecha. Dokładny opis kościoła, który był prawdopodobnie fundowany przez Krzyżaków i jego wyposażenia. Porządek nabożeństw. Uposażenie kościoła. Witrykusami byli: Michał Frostt, Stanisław Szczęsny i Wojciech Chojnicki. Uposażenie proboszcza z podaniem stanu zabudowań plebańskich i inwentarza. Wspomniano przy tym, że dawniejszy proboszcz bobowski i dziekan starogardzki, Tomasz Długoński, odchodząc na parafie w Lubiszewie, niewiele pozostawił z inwentarza. Wsie parafialne: Bobowo, Wysoka, folwark Żabieński, Smoląg. Do sakramentów było zdolnych 390 wiernych, nawróconych 16, zaś luteran 47. Był szpital. Opis uposażenia organisty. Proboszcz Wojciech Piątkowski, dziekan starogardzki, liczący lat 52, będący tu od lat 17, zaś organista Kazimierz Liszkowski, s. 121-126.

D ą b r ó w k a. Wieś w starostwie gniewskim. Kościół murowany, fundowany prawdopodobnie przez Krzyżaków, pw. Podwyższenia Krzyża Świętego, ale nie przechowywano w nim Najświętszego Sakramentu. Opis świątyni i jej wyposażenia. Opis nabożeństw odprawianych w co trzecią niedzielę, ponieważ ta parafia została afiliowana do parafii w Bobowie. Uposażenie kościoła i proboszcza. Witrykusami byli Jan Ossowski, sołtys z Dąbrówki, Jakub karczmarz i Michał Zblewski. Do parafii należała jedynie wieś Dąbrówka, zaś parafią administrował proboszcz z Bobowa, s. 127-129.

$\mathrm{P}$ ą c z e w o. Wieś z kościołem murowanym pw. Narodzenia Najświętszej Marii Panny i boczną kaplicą, która fundował Placyd Jan Kitowski. Kaplica z powodu zacieków prawie, że zupełnie zniszczona. Najświętszy Sakrament przechowywano. Dokładny opis świątyni i jej wyposażenia. Opis nabożeństw, odprawia-

${ }^{86}$ Protokół nie został dokończony, o czym świadczy pozostawione puste pół strony, stąd brak informacji o służbie kościelnej, 
nych w co drugą niedzielę, ponieważ z tą parafią była złączona parafia w Czarnym Lesie. Uposażenie kościoła. Witrykusami byli Tomasz Klejna, Michal Koliweszka, stary Gajdus, i dwóch niepodanych z imienia. Do parafii należało Pączewo i Wolental. Do sakramentów z Pączewa przystępowało 200 osób, z Wolentala 180. Opis uposażenia proboszcza i inwentarz. Parafią administrował Jan Augustyn Silski, od 11729 r. Miał wikariusza Macieja Łęgowskiego i organistę Stanisława Latoszewicza, s. 130-135.

C z a r n y L a s. Wieś szlachecka rodziny Bystram w starostwie gniewskim, z kościołem murowanym, pw. św. Andrzeja. Dokładny opis świątyni i jej wyposażenia. Nabożeństwa w niedziele na przemian z parafią w Pączewie oraz na świętego Andrzeja, Mateusza i Józefa. Uposażenie proboszcza. Witrykusami byli: niejaki Pawelec i Mokwa, zaś prowizorem troszczącym się o lampę (przed Najświętszym Sakramentem), niejaki Rogatz. Do parafii należały wsie: Czarny Las, Zelgoszcz, folwark Wda, folwark Bukowiec i osada młyńska Krek, osada węglarza w lesie. Ogółem było 411 wiernych, s, 136-138.

$\mathrm{K} 1$ o n ó w k a ${ }^{87}$. Miejscowość ta została tu nazwana miastem (oppidum), której dziedzic był kolatorem świątyni murowanej, pw. św. Katarzyny. Najświętszy Sakrament przechowywano. Dokładny opis stanu świątyni i jej wyposażenie. Proboszczem był od 12 VI 1712 r. Szymon Józef Ćwikliński ${ }^{88}$. Wsie parafialne: Klocówka, Rywałd, Nowy Dwór [Pelpliński], Lipinki. Parafia administrowana przez proboszcza z Rajkowych. Organsta także ten, co we wspomnianej parafii. Witrykus Wawrzyniec Błaszkowski, s. 139-141.

L u b i c h o w o. Wieś królewska $\mathrm{z}$ drewniana świątynia parafialną, pw. św. Jakuba. Opis świątyni i jej wyposażenia oraz nabożeństw, sprawowanych w co trzecią niedzielę i niektóre święta, ponieważ była to parafia inkorporowana do parafii Zalewo. Najświętszy Sakrament przechowywano. Wsie parafialne: Lubiechowo $^{89}$, Ossowo, Bietlowo, Steklno, Zielona Góra, Ocepel. Powstawały też nowe małe osiedla. Wspomniano, że około 1641 r. był proboszczem w Zblewie, a potem Bobowie, Mikołaj Topolski, zaś w 1686 Jan Lwowecki. Parafia administrował Józef Wenda, proboszcz w Zblewie i Pińczynie, urodzony w 1695 r., a w parafii od 1728 r., s. 142-145.

Ł ą g. Wieś królewska w starostwie tucholskim. Drewniany kościół filialny parafii w Czersku, pw. Narodzenia Najświętszej Marii Panny. Nie przechowywano Najświętszego Sakramentu. Opis świątyni. Nabożeństwa powinny być w co trzecią niedzielę, ale są rzadziej z powodu starości proboszcza. Witrykusani byli Łukasz Wąs i Wawrzyniec Sołtys. Wsie parafialne: Łąk, Prusy, Zawada, Wieck, Złe Mięso, Zimne Zdroje, Tleniny, Bądźmierzawice. Liczba wiernych ma być

${ }^{87}$ Ten protokół spisano częściowo w języku polskim.

${ }^{88}$ Zapis nieco niejasny, ponieważ dalej podano, że parafia administrował proboszcz z Rajkowych.

${ }^{89}$ Tak tu napisani. 
podana przy wizytacji Czerska. Luteranie byli we wsi Prusy, gdzie właściciel wsi, Wonder Lindau, miał swój (pewnie dla akatolików) cmentarz, s. 146-147.

C z e r s k. Wieś królewska w starostwie czerskim. Kościół parafialny nowy, drewniany, pw. św. Marii Magdaleny. Przechowywano Najświętszy Sakrament. Opis świątyni i jej wyposażenia oraz uposażenia. Starość proboszcza powodowała, że często nabożeństwa nie były sprawowane. Uposażenie kościoła i proboszcza. Parafią administrował Stanisław Józef Łęski, od lat 13, ale z powodu starości niezdolny do sprawowania sakramentów i mszy, a wikariusza nie posiadał. Prowizorem był Franciszek Kliński, sędzia tczewski, organistą Stanisław Kruziewski, zaś witrykusami Szymon Powroźnik i Grzegorz Gottera. Wsie parafialne: Czersk, Niezdrowa, Rytel, Malechin, Mokre, Lutom, Zapędowo, Legbąd oraz pustkowia: Łosiny, Twarożnica, Kurcze, Uboga, Kanigort, Ostrowy, Kodnia, Sienica, Cis, Lubno, Juncza, Magierki Młyn. Wiernych było 800 osób, ale nie wiadomo czy wszyscy się spowiadali, ponieważ proboszcz był stary, chyba w sąsiednich proboszczów. Luteran naliczono 20, zaś Żydów 4 osoby, s. 148-150.

$\mathrm{S}$ t a $\mathrm{r}$ a $\mathrm{K}$ i s z e w a ${ }^{90}$. Wieś królewska $\mathrm{z}$ kościołem drewnianym pw. św. Marcina. Najświętszy Sakrament przechowywano. Dokładny opis świątyni i jej wyposażenia. Porządek nabożeństw Uposażenie parafii i proboszcza oraz wykaz inwentarza gospodarskiego. Wsie parafialne z podaniem ilości wiernych: Stara Kiszewa 120, Podzamcze 66, Chwarzno 35, Cireciorka 6, Nierybno 9, Studzienice 20, Bartel 14, Wygoniun 18, Konarzyny 52, Babie 4, Bartoszów Las 10, Ciegardło 12, Tyszarstwo 4, Golun 12, Olpuch 20, Nowa Kiszewa 9, Nowy Bukowiec 3, Stary Bukowiec 30, Fosuta 5, folwark Bukowiecki 3, Chwarscienko 32, Stare Polaszki 51, Pałubie 18, Maliki 4, Dubrek 4, Struga 6, Boże Pole 21. Ogółem do sakramentów było zobowiązanych 643 osoby. Proboszczem był Jan Białachowski, liczący lat 45, w parafii od 17 IX 1712 r., s. 153-159.

$\mathrm{S}$ t a re P o la s z ki. Wieś królewska z nowym kościołem wystawionym z pruskiego muru pw. św. Mikołaja. Opis świątyni i jej wyposażenia, gdzie jednak Najświętszego sakramentu nie przechowywano. Odprawiano tu w co trzecią niedzielę. Organista i witrykusi ci sami co w parafii Stara Kiszewa [pewnie i ten sam proboszcz], s. 160-162.

P i ń c z y n. Wieś królewska z kościołem drewnianym, starym i wymagającym restauracji, pw. św. Jana Chrzciciela. Opis świątyni i dokładny wykaz jej wyposażenia. Nabożeństwa w co trzecią niedzielę, gdyż nie było tu własnego proboszcza, ani wikariusza i jest poddana proboszczowi z Zblewa. Uposażenie kościoła i proboszcza. Wsie parafialne: Pińczyn, Semlin, Góra, Pszenica, Sucimin, Pałubinek, , karczma zwana Borowa, Nowy Dworzec Bukowiec Górski, Bukowiec Piseński, s. 162-166.

${ }^{90} \mathrm{~W}$ innych wizytacjach pisani jedynie „Kiszewa”. 
$\mathrm{S} \mathrm{t}$ a $\mathrm{r}$ o g a r d. Miasto królewskie z kościołem murowanym. Opis świątyni pw. św. Mateusza, jej uposażenia i wyposażenia, bardzo dokładnie wyliczonego. Nie pominięto własności bractwa Różańca świętego. Opis nabożeństw. Bractwo Świętego Różańca założone w 1633 r., posiadajce odpowiednie dokumenty. Uposażenie proboszcza. Wsie parafialne: Nowa Wieś, Lewidz, Barchanowy, Rokocin, Klincz, Kucborow, Sumin, Zamek Starogardzki oraz osada opuszczona zwana Pustkowie u św. Jana. Opis zabudowań plebańskich. Wspomniano, że należącą do proboszcza krowę sprzedał Józef Plumbowski, ówczesny zarządca parafii. Proboszczem był Franciszek Chmielewski ${ }^{91}$, kanonik włocławski, nieobecny podczas wizytacji, zatrudniający tu w charakterze zarządcy Piotra Matemblowskiego, lat 33 liczącego, przy tym kościele od lat ośmiu przebywającego oraz wikariusza Jakuba Chędogowskiego. Organista nazywał się Jan Latoszewicz, który uczył osiemnastu chłopców. Witrykusi: Jerzy Zerkał i Jan Klewidz - katolicy oraz Jan Szmett i Paweł Szmett- luteranie. Wiernych zdolnych do przyjmowania sakramentów było 912 osób. Szpital, w którym przebywało pięciu ubogich miał na swoje utrzymanie cztery domki, z czego było rocznie 24 floreny dochodu, s. 167174.

N o w a W i e ś. Znajdował się tu kościół filialny parafii w Stargardzie, bardzo ubogi. Była to świątynia drewniana pw. św. Anny. Opis stanu świątyni i skromnego wyposażenia. Odprawiano tu w co trzecią niedzielę i w trzeci dzień świąt. $\mathrm{Na}$ placu, gdzie dawniej stała plebania, wieśniacy wystawili swoje zabudowania. $\mathrm{Na}$ uposażenia proboszcza były dwa łany, z których pobierał czynsz, zapewne proboszcz starogardzki, s. 175-176.

P a r c h o w o. Wieś królewska w starostwie parchowskim. Świątynia drewniana, pw. św. Mikołaja. Jej opis oraz wykaz wyposażenia i odbywanych tu nabożeństw. Uposażenie parafii. Stan zabudowań plebańskich. Proboszczem był Tomasz Chełmowski, zarządca, lat 55 liczący, Organista niepodanego imienia Dygnatowski, prowizorami zaś byli niepodanego imienia Sobański i Kazimierz Wróblewski. Wsie parafialne: Parchowo, Sulęczyno, Nakla, Galczewo, Jamno, Żukowko, Chośnica, Grabowo, Młyn Parchowski, Młyn Gemnicki, Kłodno, Sominy, Nowy Dwór Neneyfeldt, Świętek. Wiernych zobowiązanych do spowiedzi wielkanocnej było około 600 osób, akatolików około 300, zaś nawróconych za obecnego proboszcza 9 osób, s. 177-180.

S u 1 ę c z y n. Wieś dziedziczna, dawniej Hejdensteinów, aktualnie zaś Wolskich. Kościół drewniany, pw. Świętej Trójcy. Opis kościoła, jego wyposażenia oraz sprawowanych tu nabożeństw. Uposażenie kościoła i stan zabudowań plebańskich. Duszpasterzem byłliczący lat39Andrzej Gorlicki, ustanowiony tuw 1725 r. Organista nazywał się Jan Tracowski, prowizorem był szlachcic, niepodanego imienia, Zelewski, witrykusi natomiast to Mikołaj Klassa, Marcin Klassa. Wsie parafialne: Sulęczyno, Węsiory, Podziary, Bor, Zakowo, Kistowo, Zdunowice,

${ }^{91}$ Biogram tego kanonika włocławskiego zob. C h o d y ń s k i, Katalog, s. 112-114. 
Bukowa Góra, Ostrowite, Kołodzieje, Kistówko, Bielawki, Pustkowo, Chałupy Borowe, Matryc, Zdunowie Małe, Pusta. Wiernych zobowiązanych do sakramentów świętych było 623 osoby, akatolików 82, zaś nawróconych od 1720 r. 23 osoby, s. 181-184.

$\mathrm{K}$ o t k o w o. Wieś w starostwie bytomskim, z kościołem drewnianym, pokrótce opisany. Nabożeństwa odbywały się naprzemian w co trzecią niedzielę. Świątynia ta, a raczej kaplica, podobnie jak i macierzysty kościół w Borzymtuchomiu, zarządzana była przez proboszcza z Ugoszcza, Macieja Muszyńskiego, s. 185.

B o r z y t u c h o m. Wieś w starostwie bytomskim, której właściciele byli innowiercami. Świątynia wystawiona w pruski mur, pw. św. Jerzego. Opis wyglądu i wyposażenia świątyni oraz uposażenia, dosyć znacznego. Wsie parafialne, czy raczej dające uposażenia dla proboszcza: Borzetucchomie, Mosztorno, Strzyszewo, Krośniewo, Kotkowy. Do kościoła tego należało 13 wiernych, ponieważ reszta to akatolicy. Były zabudowania dla proboszcza, dosyć dobre oraz domek dla nauczyciela, s. 186.

L e ś n o ${ }^{92}$. Wieś królewska w starostwie tucholskim. Kościół drewniany, pw. Śwwietego Krzyża, zbudowany przez obecnego dziekana z Bruss, jeszcze nie konsekrowana. Opis świątyni iej wyposażenia. Nabożeństwa odbywały się w co trzecią niedzielę, ale Najświętszy sakrament był przechowywany. Na uposażenie składała się ziemia oraz świadczenia ze wsi: Leszno, folwark Leszno, Orlik, Lendy, Wysoka, Raduń, Trzebuń, Skorzewo Bukwickie, Kaszuba, Parzyn, Warszyn Bukowicki, Prądzianka Bukowicka, Kruszyn, Laska, Winkidorf. Kościół administrowany przez proboszcza z Bruss. Prowizor kościoła Michal Lisiewski z wsi Wysoka, witrykusi Adam Ormowski, sołtys wsi Redy, Jan Wera z wsi Wysoka. Organista Walenty Rakowski. Wiernych było około 750 osób oraz sporo luteran.

Kaplica we wsi O d r y, wspomniana przy opisie Leśna, drewniana, dawno już wystawiona, bez własnego utrzymania i skromnym wyposażeniem przechowywanym u miejscowego dziedzica, który też wynagradzał proboszczowi parafii Wiele, gdy tu niekiedy odprawiał, s. 187-188.

U g o s z c z. Wieś w starostwie bytomskim, ze świątynią drewnianą, pw. św. Marii Magdaleny. Dokładny opis kościoła i jego wyposażenia. Ponieważ proboszcz ma kilka kościołów do obsłużenia, stad i tu nabożeństwa w miarę możliwości. Uposażenia proboszcza. Wsie dające na utrzymanie proboszcza: Ugoszcz, Czarna Dąbrowa, Polczno, Ostowa Dąbrowa, Zelewie Pustkowie, Suminy, Przywóz, Prądzanka, Studziennie, Kłączno. Proboszcz korzystał z należących do parafii dwóch wołów i krowy. Zabudowania plebańskie, dosyć zniszczone. Dla nauczyciela mały domek. Parafią administrował z tytułem zarządcy [Maciej] Muszyński, lat 32 liczą-

${ }^{92}$ W księdze napisano „Leszno”. 
cy. Witrykus Piotr Tarnowski i organista Paweł Zdanowski. Katolików ogółem 415 osób, reszta to luteranie, nawróconych nie było, s. 191-192.

B y t o w o. Miasto w dzierżawie u elektora brandenburskiego, opanowane przez luteran, którzy mieli tu dwóch swoich. Jeden urządzał nabożeństwa około południa w kościele pw. św. Jerzego na przedmieściu dla szlachty i okolicznych luteran, rano natomiast nabożeństwo było w ich kościele w mieście.

Kościół zaś parafialny, murowany, niczym bazylika, pw. św. Katarzyny, spłonął 13 V 1700 r., częściowo odbudowany. Opis świątyni. Ponieważ proboszcz nie zawsze jest obecny, bo ma jeszcze inne kościoła, dlatego nabożeństwa z kazaniami są w co trzecią niedzielę. Uposażenie proboszcza. Meszne pobierał z wsi: Gostkowo Małe i Duże, Zembinowiec, Udorpia, Mądrzykowice, Osieko, Niedarzyno, Grzmiąca, Pomysk, Lupowsk. Zabudowania plebańskie przez aktualnego proboszcza odnowione. Proboszcz Ludwik Borzyszkowski, liczacy lat 53, w parafii od 1717 r. Organista Jan Printz, nie rezydujący na miejscu, a jedynie przyjeżdżający z proboszczem. Witrykusi: Tomasz Smoczyński, Jan Szyc, Otto Willer. Katolików było 102 osoby, reszta w liczbie około 1000 osób, to luteranie, s. 193195.

$\mathrm{T}$ u c h o m i e ${ }^{93}$. Wieś w starostwie bytowskim, opasanowana przez luteran, ktorzxy mieli tu swojego ministra. Kościół parafialny, drewniany, pw. św. Michała Archanioła, zbudowany niedawno przez Wawrzyńca Ryndwelskiego, kanonika kamienieckiego. Nie przechowywano tu Najświętszego Sakramentu. Opis świątyni. Proboszcz pobierał meszne z wsi parafialnych: Tuchomie Wielkie, Tuchomie Małe, Tągomie, Ciemno, Trzebiatkowo, Modrzewo, Piaszno. Zabudowania plebańskie odbudowane przez wspomnianego Wawrzyńca Ryndwelskiego. Parafia administrowana przez proboszcza bytomskiego.

B r u s y ${ }^{94}$. Wieś królewska w starostwie tucholskim. Kościół drewniany i stary, ponieważ mówiono, że jeszcze przez Krzyżaków stawiany, pw. Wszystkich Swiętych. Opis świątyni i jej wyposażenia. Nabożeństwa w każdą niedzielę, Było bractwo Szkaplerzna Świętego, biorące udział w niedzielnej służbie bożej. Uposażenie kościoła. Wsie parafialne: Brusy, Kossobudy, Czyczkowy, Lubnie, Zalesie, Męcikał, Turowiecki, Dąbrowski, Okręglicki, Giełdan, Pokrzywiński, Spiorewnik, Czernica, Drzewicz, Rolnik, Żabno, Chełmy Małe, Czarnowo, Czapiewice, Głowczewice, Glizno, Chełmy Wielkie. Zabudowania plebańskie niedawno odnowione. Parafia administrowana przez Szymona Kolińskiego, dziekana bytomskiego, liczącego lat 52. Prowizorem był Adam Żurocki Czapiewski, witrykus Bartłomiej Lehman Bruski, Wojciech Mleczko. Organista Wojciech Gnawiński, lat 63. Katolików było 1156 osób, niewielu luteran i jeden Żyd, s. 201-204.

\footnotetext{
${ }^{93}$ W księdze napisano ,Tuchom”.

94 W księdze napisano ,, Brussy”.
} 


\section{G56}

\section{A. OPIS KSIĘGI}

[1. Sygn. Akt.] G56.

[2. Tytuł oryg.] Vissitatio per Perillustrem Reverendissimum Augustinum Kliński ${ }^{95}$, Archidiacomum Pomeraniae in Anno 1746 expedita.

[3. daty krańc.] $1726-1750$.

[4. Opis zewn.] Łac., $2^{0}(34,0 \times 22.0 \mathrm{~cm}$,). Karta tytułowała i następne paginowane cyframi rzymskimi I-XVI. Stron o paginacji arabskiej 862. Oprawa dawna w skórę, znacznie zniszczona. Pismo czytelne i cały tekst zachowany więcej niż dobrze, ale pisana różną ręką. Wymagałaby konserwacji, ponieważ wiele jest kart luźnych i należy się z nią obchodzić bardzo ostrożnie. Karty i strony puste: s. I-II, odwrocie karty tytułowej; s. IV., s. XII-XVI; s. 20, 50, 78, 88, 100, 126, 234236, 250, 300, 334, 357-358, 362, 376, 400, 429, 452, 454-456, 468, 480, 494, $504,532,548,592,662,684,764$,

[5. Uwagi]

Księga ta musiała zostać spisana później, albo też złożona ze składek sporządzanych w różnych terminach, ponieważ napisana została kilkoma rekami. Widać to też z dat wizytacji, które nie są ułożone chronologiczne. Ponadto są ślady obcięć tekstu ma brzegach kart, co świadczy o złożeniu i oprawieniu księgi, po napisaniu jej przez różnych pisarzy ${ }^{96}$. Protokóły zaczynają się też zazwyczaj na stronie nieparzystej, co także świadczy o późniejszym zszyciu księgi.

Pisownię nazw miejscowości pozostawiono nieraz celowo w brzmieniu oryginalnym, chyba że była pewność co do obecnego brzmienia. Nie streszczono dekretów reformacyjnych, podając tylko strony, gdzie się znajdują. Niekiedy były to obszerne uwagi.

Jest często stosunkowo dużo danych biograficznych o proboszczach, ich pochodzeniu, wieku, dacie święceń itp. Wspominano też zazwyczaj oprowadzeniu przez nich ksiąg metrycznych.

Nie podawano w tekście imion i nazwisk akuszerek, chociaż zazwyczaj zwracano uwagę, czy umiały chrzcić dzieci w nagłej potrzebie.

\section{B. ZAWARTOŚĆ KSIĘGI}

Karta tytułowa z tytułem jak wyżej, s. III.

Indeks protokółów wizytacyjnych w podaniem dekanatów, parafii i stron, $\mathrm{k}$. V-VIII.

Indeks dekretów powizytacyjnych, s. IX-XI.

\footnotetext{
${ }^{95}$ Biogram tego archidiakona pomorskiego zob. C h o d y ń s k i, Katalog, s. 391-393.

${ }^{96}$ Świadczą o tym karty 283-292.
} 


\section{Dekanat tczewski}

S u b k o w y. Dnia 2 III 1746. Dokładny opis stanu świątyni. Prawo patronatu należało do miejscowego ordynariusza. Świątynia pod wezwaniem św. Stanisława, Biskupa i Męczennika. Nie było przywilejów odpustowych. Bractwa: Różańcowe, Imienia Jezus Batki Boskiej. Wykaz uposażenia. Ofiary od wiernych zbierają prowizorzy. Tabernakulum należycie utrzymane, ale światło pali się jedynie w dzień, gdy świątynia jest otwarta. Chrzcielnica stara, ale zamknięta. Piscyna była. Sześć ołtarzy, dosyć dokładnie opisanych, z dobrze zachowanymi portatylami. Jeden z nich, św. Rocha pochodzi z 1728 r. Oleje Święte przechowywane w szafie w zakrystii. Zakrystia po stronie ewangelii, a przy niej skarbiec, zamykany na dwa klucze, s. 1-3.

Wykaz dokładny inwentarza, a więc naczyń liturgicznych złotych, srebrnych i z mosiądzu, dalej wszelkiego rodzaju szat liturgicznych, s. 3-5.

Bractwo Najświętszego Imienia Jezus i Matki Bożej ${ }^{97}$ zaprowadzone przez Kazimierza Gralewskiego w 1720 r., który dał też stosowny zapis na jego uposażenie. Organista miał przewidziany dochód za śpiewanie różańca. Bractwo posiadało swoje paramenta liturgiczne, szaty oraz inne utensylia, s. 6-7.

Proboszcz Tomasz Jan Machowski, dziekan tczewski. Liczący lat 64. Wikariusz Jan Konikowski, lat 50 liczący. Uposażenie proboszcza składało się z czterech łanów ziemi, łąk i ogrodów oraz trzech domów. Wsie parafialne: Subkowy, Wacmierz, Wacmierek, Czarnin, Gorzędziej, Brzeźno, Słąca ${ }^{98}$ Wielka, Słąca Mała, Brzusce, Gniszewa. Folwarki należące do cystersów z Oliwy: Radostowo, Wielgłowy, Starczyn, folwarki należące do cystersów z Pelplina: Garcz, Narkowy, Feschbuda. Wiernych, zobowiązanych do sakramentów wielkanocnych, powyżej 1000 osób. Nie było Żydów, ani luteran. Organista, a zarazem uczącym dzieci był Michał Świdziński. W przytułku znajdowało się czterech podopiecznych, ale żyli oni z jałmużny. Opis zabudowań parafialnych i inwentarza, s. 7-8.

G o r z ę d z i e j. Kościół afiliowany do parafii Subkowy, położony na wzgórzu nad Wisłą, murowany, ale znacznie zniszczony od wichury i starości. Dokładny opis świątyni. Nosi ona wezwanie św. Wojciecha, bo, jak głosi tradycja, miał on tu sprawować mszę świętą. Nie przechowywano tu ani Najświętszego Sakramentu, ani wody chrzcielnej, ani olejów. Nabożeństwa w co trzecią niedzielę oraz w święta, s. 8-9.

Wykaz paramentów, szat i książek liturgicznych. Ołtarz wielki pod wezwaniem św. Wojciecha. Dochód proboszcza, oprócz tego, co podano przy wizytacji parafii Subkowy, składał się jeszcze z czterech łanów ziemi, znajdujących się w dzierżawie, dających roczny dochód 80 florenów. Było też inne dochody. Przytoczono tu także wykaz dochodów, jaki był zanotowany w księdze z 1724 r., z podaniem imion i nazwisk zobowiązanych do płacenia na rzecz kościoła, s. 9-12.

Dekret reformacyjny dla parafii Subkowy i Gorzędziej, s. 13-19.

\footnotetext{
${ }^{97}$ Wyżej podano, jakoby były trzy bractwa.

${ }^{98}$ Dawniej Pisano Słońca. Obecnie miejscowość ta nie występuje.
} 
T c z e w. Wizytacja 5 III 1746 r. Opis świątyni murowanej, fundowanej w 1226 r. przez książąt pomorskich, pod wezwanie. Podwyższenia Świętego Krzyża i św. Mikołaja. W 12511 r., wraz z całym miastem świątynia spłonęła. Dwie zakrystie, po stronie ewangelii i lekcji. Opis dzwonów i kaplic. Jedna z nich należała do bractwa Aniołów Stróżów. Opis trzynastu ołtarzy. Przywilej odpustowy na uroczystość Podwyższenia Krzyża Świętego. Bractwo Aniołów Stróżów, zaprowadzone przez Mikołaja, prepozyta paulinów w Topolna w 1723 r. z przywilejem odpustowym. Bractwo to nie posiadało własnego uposażenia, ale miało niektóre własne sprzęty liturgiczne, s. 21-23.

Tabernakulum nowo urządzone. Światło paliło się w dzień i noc. Chrzcielnica i oleje święte należycie utrzymane. Wykaz naczyń liturgicznych srebrnych i z mosiądzu, oraz innych paramentów i szat oraz ksiąg, s. 23-27.

Nie było uposażenie w ziemię, ponieważ przez 70 lat kościół ten był w posiadaniu luteran, i odzyskany został dzięki biskupowi Rozdrażewskiemu w 1595 r. Proboszczowie odzyskanego kościoła toczyli z mieszczanami procesy o zwrot zagarniętego uposażenie, ale to nie przyniosło skutku. Wykaz innych dochodów, s. 27-28.

Opis nabożeństw. W soboty i wigilie świąt odprawiano nieszpory. W niedziele i święta odmawiano matutinum, a po nim msza śpiewana $z$ kazaniem. Był też porządek nabożeństw przewidziany na cały tydzień, s. 28.

Notatka, że dawniej znajdował się poza miastem kościół pod wezwaniem św. Jerzego, ale uległ ruinie w 1632 r. Przy NIK był dawniej kapłan noszący tytuł prepozyta. Na prośbę mieszczan, pewnie ewangelików, z pozwolenia króla Władysława IV z 1633 r. postawili tam luteranie swój dom modlitwy. Po dawnym kościele pozostała dzwonnica $\mathrm{z}$ dzwonem ważącym około siedemset funtów, którego miasto nie chce zwrócić parafii, s. 29.

Proboszczem, ale tu nierezydującym, był Jan Franciszek Fahl, kanonik warmiński. Parafię odwiedzał jedynie raz w roku. Na miejscu zastępował go zarządca Wojciech Michał Prabucki, liczący lat 29, należycie spełniający obowiązki duszpasterskie. Uposażenie proboszcza składa się z trzech łanów ziemi znajdującej się w dzierżawie u mieszczan, co łącznie daje 210 florenów pruskich. Do tego dochodzi jeszcze 400 florenów oddawanych przez z magistratu oraz inne sumy pieniężne. Organista zbiera ofiarę od mieszczan. Wsie należące do parafii: czyżykowi, Knybawa, Bałdowo, Rokotki ${ }^{99}$, Czalin ${ }^{100}$, Suchostrzygi, Szembark ${ }^{101}$, Oliwiny. Katolików przystępujących do sakramentów wielkanocnych około 800 osób, zaś luteran powyżej 1000. Akuszerki były należycie pouczone o udzielaniu chrztu w nagłym przypadku. Przytułku nie było, ale proboszcz wyznaczył w domu plebańskim pomieszczenie, w którym przebywało trzech ubogich. Był organista, który pobierał uposażenie 52 floreny rocznie oraz jeszcze inne opłaty, s. 29-31.

Zabudowania plebańskie składały się z domu dla proboszcza i drugiego dla zarządcy. Była także stodoła. Inwentarza żadnego nie było, s. 31.

Dekret reformacyjny, s. 32-35.

\footnotetext{
${ }^{99}$ Dawniej pisano „Rokitki”.

${ }^{100}$ Dawniej pisano „Czarnin”.

${ }^{101}$ Dawniej pisano „Sztenbark”.
} 
L u b i s z e w o ${ }^{102}$. Kościół lubiszewski był afiliowany do prepozytury kościoła w Tczewie. Opis świątyni pod wezwaniem Świętej Trójcy i Wniebowzięcia Najświętszej Marii Panny. Przywilej odpustowy był z racji uroczystości Świętej Trójcy, z nadania Benedykta XIV z 1741 r. Bractwo Opatrzności Bożej zaprowadzone w 1723 r. z odpustem od papieża Innocentego XIII, staraniem Czarlińskiego, kanonika warmińskiego, który dał też roczny zapis 40 florenów na mszę za Czarlińskich oraz 15 florenów dla organisty śpiewającego podczas tej mszy. Wykaz opłat na kościół z racji pogrzebów. Były też trzy łany ziemi, dwa w pobliżu domu organisty, a jeden przy przytułku, z czego parafia miała rocznie 24 floreny. Tabernakulum. Chrzcielnica i Oleje Święte należycie utrzymane. Trzy ołtarze. Zakrystia murowana. W 1739 r., 31 sierpnia, dokonano świętokradzkiej kradzieży w kościele, s. 37-39.

Spis dokładny naczyń srebrnych z mosiądzu i cyny, a także szat liturgicznych i ksiąg oraz wszelkiego rodzaju utensylia. Spisano także inwentarz bractwa. Proboszczem był kanonik warmiński Fahl ${ }^{103}$, mający tu swojego zastępcę w osobie Stanisława Szymona Ćwiklińskiego, notariusza apostolich auctoritate, zatrudnionego w Konsystorzu Gdańskim. Jego to w parafii zastępował Jan Ćwikliński ${ }^{104}$, lat 29 mający, obowiązki swoje wypełniający należycie, s. 39-42.

Uposażenie składało się z ośmiu łanów ziemi, łąki, a także innych jeszcze, tu wyliczonych dochodów. Wsie należące do parafii: Lubiszewo, Swarożyn, Goszyn, Liniewko, Wetkowy i część należąca do Bystramów, część należąca do Wypczyńsskich, Małżewo Wielkie, Małżewko, Rukoszyn, Stanisławie. Ponadto należały dwie osady młyńskie Zwierzynek i Nowy Młyn oraz kolonia w lesie swarczyneńskim, zwana Zabawnie. Wiernych zobowiązanych do sakramentów wielkanocnych było 607 osób, Żydów było 9 we wsi Swarożyn, na co zgadzała się właścicielka Potulicka, wojewodzina czernichowska. Akatolików znajdowało się 46, ale swojego domu modlitwy nie posiadali. Akuszerki otrzymały wystarczające pouczenie. Znajdował się przytułek, ale ubodzy żyli wyłącznie z jałmużny. Organista uczył także dzieci i miał za to łan ziemi, a także pobierał jeszcze inne wynagrodzenie, w tym także od bractwa, gdy brał udział w nabożeństwach, s. 43-44.

Wykaz inwentarza plebańskiego, żywego i martwego oraz zabudowań, s. 44-46.

Dekret reformacyjny, s. 47-49.

S k a r s z e w y i filia S z c z o d r o w o. Wizytacja dnia 19III 1750 r. Świątynia murowana w mieście królewskim Skarszewy 1714 r., wraz z prawie całym miastem spłonęła. Odtąd nie ma w niej nabożeństw, ponieważ nie została ponownie konsekrowana. Wezwanie św. Michała Archanioła. Opis stanu kościoła. W aktach grodu skarszewskiego został złożony dokument z 1664 r. przeciwko mieszczanom skarszewskim, ponieważ ci nie chcą odbudować świątyni. W międzyczasie jednak doprowadzono ją do stanu używalności, ponieważ tak świadczy o tym ciąg dalszy opisu .Były przywileje odpustowe na św. Michała, i Oczyszczenia Najświętszej Marii Panny, s. 51-52.

\footnotetext{
${ }^{102}$ Napisano tu Libiszewo

${ }^{103}$ Zapewne ten sam co w Tczewie.

${ }^{104}$ Albo zbieżność nazwisk, albo byli to bracia.
} 
Opis uposażenia kościoła $\mathrm{w}$ dwa łany ziemi oraz pewne zapisy sum na procent, 52-53.

Tabernakulum należycie utrzymane i paliło się zawsze przed nim światło. Chrzcielnica zamknięta i oleje święte utrzymane w czystości. Cztery nowe ołtarze, należycie utrzymane. Relikwie szaty św. Krystyny, ale jest wątpliwość ich autentyczności, s. 53-54.

Proboszcz Franciszek Józef Wybicki, kanonik włocławski1 ${ }^{105}$, liczący lat 41, rezydujący na miejscu. Miał do pomocy w kościele w Stężycy Mateusza Jana Rychłowskiego, zaś w Skarszewach Adama Józefa Mikołajewskiego. Księgi metryk prowadzono, s. 54-55.

Uposażenie proboszcza zostało dokładnie opisane w aktach grodu skarszewskiego. Było sześć łanów ziemi oraz inne dochody. Wymieniono dalej wsie płacące tzw. meszne: Dęblin, Kamirowo, Nygut, Mirowo, Boże Pole, Bruna, Czarnocin, Pawłowo, Szczodrowo, Nowy Wiec, Świniobudy, Piece Hamerskie, karczma Czysta Woda, Basuta, Piekło Górne, Czasz Huta, Elembruk. Wiernych korzystających z sakramentów wielkanocnych było 965 . W mieście znajdowała się świątynia luterańska z kaznodzieją. Był organista. Na przytułek dla ubogich było kilka zapisów. Opis zabudowań plebańskich i inwentarza, s. 55-59.

Wykaz paramentów liturgicznych, naczyń i sprzętów srebrnych i innych szat i bielizny kościelnej, szczegółowo wyliczonych, s. 59-67.

Przy ołtarzu św. Anny znajdowało się bractwo tego imienia, zaprowadzone dawniej przez dziekana mirachowskiego, Laurowicza, posiadające własne uposażenie oraz wyposażenie w utensylia kościelne, tu wyliczone, s. 67-68.

Opis kościoła filialnego w S z c z o d r o w i e. Świątynia ta, drewniana, pod wezwaniem św. Judy Tadeusza, w 1735 r., odrestaurowana od fundamentów. Jej dokładny opis. Przywilej odpustowy na uroczystość patrona z 1746 r. Nie posiadała własnego uposażenia. Nie było bractwa. Opis stanu świątyni, s. 68-70.

Dekret reformacyjny dla parafii Skarszewy i filii Szczodrowo, s. 71-77.

W y s i n. Wizytacja 24 III 1750 r. Wieś biskupa włocławskiego z kościołem drewnianym. Opis świątyni i jej wyposażenia w sprzęty liturgiczne. Nosiła wezwanie Wszystkich Świętych, Nie było żadnego bractwa. Przywileje odpustowe na uroczystość Znalezienia Świętego Krzyża, św. Rocha i Wszystkich Świętych. s. $79-81$.

Uposażenie parafii stanowiły dwa domy, dające roczny dochód, ofiary zbierane przez witrykusów oraz połowa dochodów z pogrzebów. Proboszcz natomiast miał dochód z jednego domu wydzierżawionego, z akcydensów i z sześciu łanów, a także z musznego pobieranego z wsi Wysin, Szarpaty, Skrzydłowo, Wiec Stary, Trzepowo, Szymles, Dolne Piekło, Łąki. zabudowania plebańskie bardzo stare, ale przez aktualnego proboszcza naprawiane. Nauczyciel miał domek stary dwoma ogrodami i łanem ziemi. Pobierał też wynagrodzenie od parafian, s. 81-82.

Witrykusami byli Piotr Pustka Dąbrowski, Kazimierz Knieja ze Skrzydłowa, Adam Dysarczyk ze Skrzydłowa. Posiadali oni klucze od skarbony. Wykaz go-

${ }^{105}$ Biogram tego kanonika, a następnie archidiakona pomorskiego zob. C h o d y ń s ki, Katalog, s. 1020-102. 
spodarowania tymi pieniędzmi w formie imiennych pożyczek, a także wykaz zapisów. Nie podano imienia i nazwiska proboszcza, chociaż bezimiennie jest wspomniany, s. 82-84.

Dekret wizytacyjny, s. 85-87.

T r ą b k i ${ }^{106}$. Wizytacja 15 marca 1746. Kościół parafialny nowo wystawiony, murowany z fundacji Konstancji Czapskiej (mianom zamiar podać lata rozpoczęcia i zakończenia budowy, ale pozostawiono puste miejsce), wojewodziny pomorskiej. Opis wielkości i wygładu świątyni.. Prawo patronatu należało do króla, Nie był jeszcze konsekrowany. Nie było przywilejów odpustowych, jedynie dla bractwa różańcowego. Trzy ołtarze. Na jej utrzymanie zbierano składkę podczas kazań. Opis bogatego wyposażenia świątyni, s. 89-93.

Parafia zarządzał Adam Zaremba, proboszcz z Kłodawy, ale osobiście lub przez wikariusza odprawia w każda niedziele i święta, s. 93.

Uposażenie proboszcza stanowiły cztery łany ziemi, z czego połowę stanowiły lasy, ponadto czynsz z jednego domu, a także pobierał pewna zapłatę z zamku sobowidzkiego, s. 93.

Wsie parafialne z których pobierano meszne: Sobowidz ${ }^{107}$, osada młyńska Sobowidz, Kępiny, osada młyńska klepiny, , Tąbki, Ełganowo, Rostołowo ${ }^{108}$. Wiernych zobowiązanych do sakramentów wielkanocnych 323. Jeden Żyd i około 50 luteran. Akuszerki potrafiły udzielać sakramentu chrztu. Był organista rezydujący przy kościele. Nie było przytułku, ani funduszu na niego. Opis zabudowań plebańskich starych, częściowo naprawionych, s. 93-94.

Dekret reformacyjny, s. 95-99.

M i ł o b ą d z. Wizytacja 8 marca 1746 r. Opis murowanego kościoła, umocnionego dwudziestoma kolumnami. Dosyć dokładny opis dobrze utrzymanej świątyni, wewnątrz pobielonej, krytej dachówka, z wieżą spełniająca role dzwonnicy. Nosiła wezwanie św. Małgorzaty i była prawa patronatu biskupa włocławskiego Przywileje odpustowe dla bractwa różańcowego, na św. Walentego, św. Małgorzatę i św. Michała. Trzy ołtarze z portatylami. Opis wyposażenia w paramenty kościelne, s. 101-106.

Opis uposażenia parafii z należących don domów, z saum zapisanych, a także z opłat od pogrzebów w świątyni i na cmentarzu, s. 106-107.

Proboszczem był Marcin Józef Zalewski, ale nie był obecny podczas wizytacji, a zastępował go Andrzej Głowiński, s. 107.

Uposażenie proboszcza stanowiły cztery łany ziemi, a ponadto powinny należeć jeszcze trzy łany i pewien obszar ziemi zwany Grodzisko, jak to świadczy przywilej biskupa [Macieja] Łubieńskiego z 1641 r., poświadczony przez bpa Gniewosza w 1644 r. Były też inne posiadłości, jak cztery domy, łąki, wspólne pastwisko, s. 107-108.

\footnotetext{
${ }^{106}$ Obecnie Trąbki Wielkie w archidiecezji gdańskiej.

${ }^{107}$ Obecnie samodzielna parafia.

${ }^{108}$ Obecnie nie wystepuje.
} 
Wsie parafialne: Miłobądz, osada młyńska, Mieścin, Koliny ${ }^{109}$, Pszczółki, Rębielcz ${ }^{110}$, Łukęcin, Dalwin, Dabrówka [Tczewska], Zajączkowo, Szpegawa, Skowarcz ${ }^{11}$. Liczba wiernych zobowiązanych do sakramentów wielkanocnych około 600 osób, luteran było około 500, którzy mieli swój zbór w Rebielczu. Żydów nie było. Nie wiadomo. Czy akuszerki tej parafii potrafią chrzcić. Przytułek znacznie zniszczony, ale mieszkało w nim trzech ubogich, żyjących z jałmużny. Na terenie parafii, we wsi Dalwin był kościół, ale poniżej zostanie opisany. Organista uczył także dzieci i miał wystarczające wynagrodzenie, s. 108-109.

Opis zabudowań plebańskich i wykaz (dokładny) inwentarza żywego i martwego, a także i książek (około 50 egzemplarzy), s. 109-112.

D a 1 w i n. Świątynia cała drewniana, pod wezwaniem św. Mikołaja, filia parafii Miłobądz Opis świątyni i skromnego uposażenia oraz paramentów liturgicznych tu się znajdujących. Było uposażenie dla proboszcza z czterech łanów ziemi i trzech domów dających czynsz roczny, s. 112-114.

Dekret reformacyjny dla parafii Miłobądz i kościoła w Dalwinie, s. 114-116.

G i e $\mathrm{m} 1$ i c e ${ }^{112}$. Wizytacja 10 marca 1746 r. Wieś należała do jezuitów z konwentu gdańskiego. Świątynia murowana, kryta dachówką, pod wezwaniem św. Jana Chrzciciela. Prawo patronatu należało do jezuitów. Opis kościoła, z trzema ołtarzami, niedawno naprawianymi. Sam kościół nie posiadał osobnego uposażenia, jedynie z ofiar zbieranych przez witrykusów podczas kazania. Wykaz paramentów liturgicznych, dosyć bogaty, spisany przy obejmowaniu probostwa przez obecnego proboszcza, s. 117-121.

Proboszczem był Karol Stanisław Boryszewski. Uposażenie proboszcza stanowiły dwa łany ziemi, pewne świadczenia od parafian, mesznego ze wsi Giemlice i skromnych ofiar z racji posługi kapłańskiej. Liczba wiernych około 300 osób. Do zboru akatolickiego w Żuławce uczęszczało około 500 osób. Akuszerka była należycie pouczona. Był organista, który także uczył dzieci, s. 121-122.

Opis zabudowań plebańskich, drewnianych, pod dachówką, wystarczająco wygodnych oraz inwentarz żywy i martwy, s. 122.

Dekret reformacyjny, s. 123-125.

N i e d a m o w o ${ }^{113}$. Wizytacja w 1750 r. Stan i dochód kościoła filialnego w Niedamowie i filialnego w Rekownicy ${ }^{114}$. Niedamowo, to wieś szlachecka, z kościołem pod wezwaniem św. Mikołaja i św. Marii Magdaleny,. Kolatorem jest miejscowy dziedzic Piotr Kliński. Opis świątyni. Utrzymana należycie. Kaplic publicznych i zakonów w parafii nie było, a także brak przytułku, s. 127-128.

Proboszcz Jan Pieczkowski, lat 47, w parafii od 1735 r. Nie było wikariusza.

\footnotetext{
${ }^{109}$ Pewnie obecny Kolnik

${ }^{110}$ Obecnie w parafii Żelisławki archidiecezji gdańskiej.

${ }^{111}$ Obecnie w parafii Pszczółki archidiecezji gdańskiej.

${ }^{112}$ Obecnie w archidiecezji gdańskiej.

${ }^{113}$ Wydaje się, że od tego miejsca księga pisana inną ręką.

${ }^{114}$ Obecnie samodzielna parafia.
} 
Akuszerki były pouczone o udzielaniu chrztu. Do sakramentów wielkanocnych było 320 wiernych, zaś luteran 220, ale nie mieli tu swojego zboru. Proboszcz gorliwie spełniał swoje obowiązki, s. 128-129.

Bractwo różańcowe, zaprowadzone przed dziesięcioma laty, posiadające swoje uposażenie, a także i swoje paramenty, s. 129.

Wykaz paramentów liturgicznych parafialnych, dosyć bogaty, s. 130-132.

Uposażenie proboszcza z czterech łanów ziemi. Meszne pobierał z wsi parafialnych, a mianowicie: Niedomowo, Dębogórzy, Stawiska, Podleś Mały i Podleś Wielki, Lubań. Stan zabudowań plebańskich., s. 132.

R e k o w n i c a, wieś szlachecka i kościołem drewnianym, znacznie zniszczonym przez wichry, ale odbudowana z odzyskanego materiału, pod wezwaniem św. Michała Archanioła. Prawo patronatu należało do kilku szlachciców. Opis świątyni i wyposażenia. Uposażenie stanowiły dwa łany ziemi z ogrodem nad rzeką, a także uposażenie dla organisty. Meszne pobierano ze wsi: Rekownica, Śledziowa Huta, Bendominek, Młyn Kulmerski, Papiernia, Płociczno. Kościołowi temu byli winne różne osoby pieniądze, tu wyliczone, s. 133-135.

Dekret reformacyjny dla kościoła w Niedamowie i Dekownicy, s. 136-142.

G o d z i s z e w o i kaplicą w Obozinie. Wizytacja 15 marca 1750 r. Godziszewo należało do dóbr opata z Lądu, którym aktualnie był Antoni Mikołaj Łukomski. Świątynia w Godziszewie zostało zbudowana od fundamentów w '748 r. przez wyżej wspomnianego opata. Kościół ten i kaplica w Oboźnie przez papieża w 1455 r. została inkorporowana do wspomnianego opactwa. Opat cystersów ma prawo patronatu. Świątynia w Godziszewie jest pod wezwaniem św. Jana Nepomucena i na dzień tego patrona jest przywilej odpustowy, nadany przez papieża Benedykta XIV w 1741 r. Opis stanu świątyni, stanu przechowywania Najświętszego Sakramentu i ołtarzy, s. 143-145.

Było bractwo św. Franciszka z Asyżu, z odpustem od papieża Benedykta X oraz bractwo różańcowe, zaprowadzone przez zakon dominikanów, także z odpustem, zaprowadzone w 1739 r. Posiadało zapisy na swoje utrzymanie, s. 145$-146$.

Przytułek bardzo zniszczony, ale przebywało w nim 6 ubogich, zyjących z jałmużny. Dzieci uczy nauczyciel. Akuszerki były należycie pouczone, s. 146.

Przy kościele Godziszewskim jest rezydencja dla proboszcza, którym był Antoni Libaber, a jego wikariuszem Edmund Grolewski, obydwaj z diecezji poznańskiej. Dochód musznego pochodzi ze wsi: Zygowice, Damaszka, Turze Wielkie, Trzcińsk, Gołębiewo Małe, Gołębiewo Wielkie, Rościszewo, Kobierzyn, Turze Małe, Rościszewo, Strzebierzyn ${ }^{115}$, Boroszewo, Boroszewko. Do Komunii wielkanocnej przystępowało 760 osób, zaś luteran było około 100 osób. Żyd był jeden, s. 146-147,

Wykaz paramentów liturgicznych, bardzo bogaty, s. 148-153.

${ }^{115}$ Może to obecny Szczerbięcin. 
We wsi szlacheckiej Sartowskich, Obozin, znajdował się kościół murowany, pod wezwaniem św. Michała Archanioła. Fundowany przez Jana Loca, który też zapisał na uposażenie były trzy łany ziemi, z których korzystał proboszcz Godziszewski. Na cmentarzu przykościelnym chowali się także akatolicy. Nabożeństwa odprawiał niekiedy kurator z Godziszewa. Meszne powinno być oddawane z wsi: Obozin, Janin, Jastrzębie i Kazimierowo. Opis ołtarzy i dosyć bogatego wyposażenie, s. 153-159.

Dekret reformacyjny dla Parafii Godziszewa i kaplicy w Obozinie, s. 159-162 .

G a r c z y n. Wizytacja 23 marca 1750 r. Wieś szlachecka, należąca do Michała Tucholskiego, do którego należy prawo patronatu. Kościół nosił wezwanie Świętej Trójcy i św. Andrzeja Apostoła. Opis wyglądu i stanu świątyni, z trzema ołtarzami, s. 163-165.

Uposażenie kościoła składało się z połowy ofiar z racji pogrzebów oraz z ofiar zbieranych do skarbony przez witrykusów. Przywilej odpustowy z racji święta św. Andrzeja. Bractwa nie było, ale przygotowano powołanie bractwa różańcowego. Nie było żadnych kaplic publicznych, ani klasztorów. Dawniej parafia ta była inkorporowana do parafii w Wysinie. Proboszcz Józef Stanisław Słomiński, od 1727 r. Nie było nauczyciela. Akuszerki umiały chrzcić dzieci. Parafia liczyła 321 osób przystępujących do sakramentów wielkanocnych. Innowierców na terenie parafii było 250 osób, ale swojego zboru nie posiadali, s. 165-166.

Uposażenie proboszcza stanowiły cztery łany ziemi oraz meszne z wsi: Garczyn, Krtowo ${ }^{116}$ Równe, Sobącz, Liniewko, Lubiszyn, Liniewo, Plachty, Harnikowy Wielkie i Małe ${ }^{117}$. Zabudowania plebańskie wymagały odbudowy. Dal nauczyciela i organisty był dom dobry z ogrodem i uposażenie, ale ostatnio organista zmart, s. 166-167.

Wykaz wyposażenia w paramenty liturgiczne i inne, dosyć bogaty. Osobno wyszczególniono to, co przybyło za aktualnego proboszcza, s. 167-169.

Dekret reformacyjny, s. 170-172.

Dekret odnoszący się do musznego z wsi Krotowo i Równe, z roku $1756^{118}$. Jest to wyciąg z akt sądowych tczewskich, s. 172-174.

Orzeczenie wizytatora odnoszące się do musznego ze wsi Harnikowy Wielkie i Małe, wystawione w Niedamowie dnia 1 kwietnia 1756 r.

\section{Dekanat gniewski ${ }^{119}$}

G n i e w. Wizytacja tego kościoła prepozyturalnego z dnia 22 lutego $1746 \mathrm{r}$. Opis świątyni pod wezwaniem św. Mikołaja, murowanej, częściowo naprawianej w 1710 r. przez Kuberskiego, zarządcy zamku w Gniewie, a aktualny prepozyt

\footnotetext{
${ }^{116}$ Może Kartowo, które zna Tomczak.

${ }^{117}$ Te dwie wsie nie zidentyfikowane.

${ }^{118}$ Data ta każe się domyślać, że księgę te spisano później, na podstawie dawnych zapisów.

${ }^{119}$ Od tego miejsca księga pisana inna ręka.
} 
naprawiał okna. Prawo patronatu należało do króla. Przywileje odpustowe na święto Zesłania Ducha Świętego i jeszcze inne. Bractwo Różańca świętego i św. Anny, ale utrzymywały się tylko z jałmużny. Kościół nie posiadał specjalnego uposażenia, a tylko procent od 1000 florenów pruskich, złożonych przez Barbarę Niewieścińską i zabezpieczonych na dobrach mieszczan Jakuba Hela i Elżbiety oraz grunt zwany Młyńska Rola, wydzierżawiony Maciejowi Heyszer, dający roczny czynsz. Opis wnętrza świątyni z sześcioma ołtarzami. Do parafii należał filialny kościół w Tymawie., s. 177-179.

Wykaz paramentów liturgicznych, bardzo bogaty, s. 179-183.

Prepozytem był Michał Dąbrowski, kanonik poznański, pochodzący z Pomorza, posiadający dyspensę na łączenie beneficjów. Kiedy był a parafii, administrował sakramenty, mając do pomocy dwóch zastępców [wikariuszy]. S. 183.

Jan Kazimierz Jugowski, archidiakon pomorski ${ }^{120}$, złożył swego czasu 4000 florenów pruskich, zabezpieczonych na mieście królewskim Gniew, aby codziennie było śpiewane oficjum o Matce Bożej. Druga fundacja była od Wojciecha Stanisława Radziwiłła, kanclerza litewskiego i starosty gniewskiego dla wikariusza, który miał głosić kazania. Proboszcz nie pobierał wygórowanych opłat za posługi religijne, s. 183-184.

W parafii, oprócz prepozyta było w parafii dwóch kapłanów. Jeden to Jan Żabiński, poprzednio pracujący w Garczu, i drugi Jan Jagielski, s. 184.

Uposażenie prepozyta składało się z 23 domów i karczmy, co dawało rocznie 298 florenów. Była teżiinna karczma, które oddawałazima piwo. Dziesięcinaimeszne z Gniewa wynosiła 124 florenów. Były i inne jeszcze dochody. Było też kilka ogrodów oraz grunta, tu opisane, dzierżawione przez miecznika Franciszka Loka, s. $184-185$.

Do parafii należało miasto Gniew z przedmieściami oraz wsie: Gronowo Wielkie i Małe, folwark Cierzpice, Ciepłe, Janszdorf ${ }^{121}$, Wielka Pastwa ${ }^{122}$, Gniewskie Pole, Szalwinek, Hamrowe Dwory, Gucz, Nowe Lichnowy ${ }^{123}$. Katolików spowiadających ssie na Wielkanoc było 1050 osób, Żydów nie było, zaś innowiercy posiadali swój zbór i własny cmentarz, Nawróconych od 1729 r. było 68 osób. Akuszerki były pouczone o sposobie udzielania chrztu. Był organista, kantor, nauczyciel i zakrystianin. Posiadali domy i uposażenie, tu opisane, s. 185-'186.

Przytułek, wprawdzie zniszczony, ale mieszkało w nim 9 ubogich. Wykaz uposażenia dla przytułku, z czego korzystali ubodzy, s. 186-187.

Opis zabudowań plebańskich i inwentarz, s. 187-188.

Inwentarz własności bractwa różańcowego, głównie paramenty liturgiczne, liczne i bogate, s. 188-190.

Inwentarz rzeczy należących do bractwa św. Anny, s. 190-191.

Wykaz dokumentów i różnych zapisów, znajdujących się w archiwum parafialnym, zaczynających się od 1204 r., z krótkimi regestami, s. 191-194.

\footnotetext{
${ }^{120}$ Biogram tego archidiakona zobacz: C h o d y ń s k i, Katalog, s. 346, 348-350.

${ }^{121}$ Nie zidentyfikowano.

${ }^{122}$ Lekcja niepewna,

${ }^{123}$ Miejscowości niezidentyfikowane.
} 
Odpis dokumentu króla Jana III [Sobieskiego] z 1689 r., wydanego w Warcie, dotyczący muzyków przy kościele w Gniewie, s. 194-197.

Kościół filialny w T y m a w i e., należący do parafii Gniew. Opis świątyni wystawionej w pruski mur, ostatnio częściowo naprawianej staraniem, niepodanego imienia, Januszewskiego, starosty gniewskiego. Opis świątyni. Prawo patronatu należało do króla, zaś patronem kościoła był św. Michał Archanioł. Opis wnętrza z dwoma ołtarzami. Wykaz paramentów liturgicznych, s. 197-198.

Nabożeństwa bywały odprawiane w trzeci dzień świąt, niedziele i święta. Opis uposażenia proboszcza, z dwóch domów, czterech łanów ziemi, będących w dzierżawie, a także z uposażenia dla organisty, którego przy kościele tym nie było. Dochód z wszystkiego pobierał proboszcz [z Gniewu], s. 199.

Wsie należące do tego kościoła: Tymawa, Rakowice, Jaźwiska, Bielawy. Żydów nie było. O luteranach powiedziano przy opisie parafii Gniew. Akuszerki były odpowiednia poinstruowane. Nauczyciel uczył dzieci podstaw czytania i podstaw wiary. Przytułku nie było, s. 199.

Dekret reformacyjny dla parafii Gniew i kościoła w Tymawie, s. 200-214.

P i a s e c z n o ${ }^{124}$. Wizytacja 18 października 1745 r. Wypisy z ksiąg parafialnych o łaskach za sprawą wstawiennictwa Matki Bożej, czczonej w obrazie znajdującym się w Piasecznie. Kościół tam fundował król. Podano trzy przykłady cudownych uzdrowień, s. 216-216.

Opis murowanego kościoła pod wezwaniem Narodzenia Najświętszej Marii Panny. Był prawa patronatu królewskiego. Przywileje odpustowe z 1738 r. na święto patronalne Narodzenia Najświętszej Marii Panny. Bractwo Szkaplerza Najświętszej Marii Panny z góry Karmel, na prośbę ówczesnego proboszcza Stanisława Stojanowskiego, zaprowadzone przez biskupa włocławskiego Macieja Łubieńskiego, za zgodą Łukasza Drzazgowskiego, prowincjała karmelitów i przeora tegoż zakonu z Bydgoszczy Floriana Mieszczańskiego, co zaaprobował następny biskup włocławski, Mikołaj Gniewosz. Uposażenie kościoła stanowiły ofiary oraz zapisy pewnych sum, tu wyliczone, s. 216-218.

Odpis dokumentu Wojciecha Stanisława Radziwiłła z 4 lipca 1848 r. na fundusz światła przed obrazem Matki Bożej w Piasecznie, co zostało zapisane w aktach gniewskich dnia 24 lipca 1648 r., s. 218-220.

Opis wnętrza świątyni, zez wróceniem uwagi na ołtarz główny, z obrazem Matki Bożej, słynący łaskami, s. 220-221.

Do parafii w Piasecznie była afiliowana parafia w Opaleniu, s. 221.

Inwentarz paramentów liturgicznych oraz dosyć bogatej biblioteki, s. 221-228 .

Proboszczem był Adam Niesiołowski, wikariuszem zaś Andrzej Schulz, obaj z diecezji [kujawsko]-pomorskiej, s. 228.

Uposażenie proboszcza składało się z procentów od pewnych sum, tu wyliczonych, musznego płaconego z wsi Piaseczno, Jelenie i Bielsk, trzech domów na ziemi plebańskiej stojących, innych przywilejów, miedzy innymi prawo propina-

${ }^{124}$ Od tego miejsca pisała inna ręka. 
cji. Ponadto proboszcz posiadał siedem łanów ziemi, cztery od dawna, trzy zaś z nadania Wojciecha Stanisława Radziwiłła, czego dokument z 1648 r. został tu przytoczony. Darowizna ta została najpierw zatwierdzona przez króla Jana Kazimierza, a potem przez króla Augusta II, którego dokument wystawiony w Warszawie, dnia 5 maja 1699 r., został tu przytoczony w całości, s. 228-232.

Wsie parafialne: Piasecznom Jelenie, Bielsk i Wyręby. Parafian spowiadających się na Wielkanoc było osób 250, niewierzących (pewnie Żydów) nie była, luteran zaś około 15. Akuszerki wystarczająco pouczone, Organista uczy głównych zasad wiary i podstaw czytania i pisania. Dom organisty wymagał naprawy. Pobierał wynagrodzenie. Był przytułek, ale zniszczony ze starości, ale nie wiadomo, czy proboszcz zamyśla wystawić nowy, chociaż do szpitala należała ziemia. Na niej wystawił dom zakrystianin, Jakub Libiszewski, zwany inaczej Wilk, s. 232233.

Opis zabudowań plebańskich i inwentarz, s. $233^{125}$.

O p a 1 e n i e. Wizytacja 17 października 1745. Kościół murowany w tzw., pruski mur, znacznie zniszczony, pod wezwaniem Apostołów Piotra i Pawła. Opis świątyni i zniszczeń. Prawo patronatu należało do biskupa włocławskiego, który był zobowiązany do naprawy świątyni. Opis wnętrza, którym nie przechowywano Najświętszego Sakramentu.. Wykaz paramentów liturgicznych. Proboszcz ten, co w Piasecznie. Wsie należące do parafii: Opalenie, , Mysterwald ${ }^{126}$, Aplinki Wielkie i Małe, Widlice, inaczej Podgórze, , karczma Przewóz nad Wisłą. Katolików spowiadających się około 150. luteran około 150. Żydów nie było. Akuszerki były dostatecznie pouczone. Organisty i nauczyciela nie było. Przytułek w ruinie. Zabudowania plebańskie zniszczone i żadnego inwentarza nie było, s. 237-239.

Dekret reformacyjny, s. 240.

N o w a C e r k i e w. Wizytacja 8 listopada 1745 r. Opis świątyni, częścią murowanej, częścią $\mathrm{w}$ tzw. pruski mur wystawionej. Była pod wezwaniem św. Piotra i Pawła, i św. Anny, patronatu natomiast opata z Pelplina. Były przywileje odpustowe. Bractwo Różańcowe, zaprowadzone w 1623 r. staraniem opata pelplińskiego Leonarda Rembowskiego, s. 241-242.

Opis uposażenie kościoła, na które składały się opłaty z pogrzebów, procent od zapisanej przez poprzednich proboszczów sumy 800 florenów i czynszu z kilku domów, s. 242.

Opis wnętrza świątyni i pięciu ołtarzy. Wykaz wyposażenia w paramenta liturgiczne, dosyć bogate, s. 242-245.

Proboszczem była zakonnik z opactwa pelplińskiego Jan Nivardus Wyczechowski, pochodzenia szlacheckiego i notariusz publiczny, rezydujący na miejscu. Miał wikariusza Jerzego Dominikowskiego, s. 245.

Opis uposażenie proboszcza, składającego się z czterech łanów ziemi, ogrodów i kilku domów, a także z mesznego, s. 245-246.

${ }^{125}$ Ponieważ strona 233 nie jest zapisana do końca, a następne są puste, wygląda na to, inwentarz nie jest kompletny i miano go uzupełnić. Nie ma też zapisanego dekretu reformacyjnego.

${ }^{126}$ Może obecny Dębowy Las. 
Wsie parafialne: Nowa Cerkiew, Ropuchy, Rożental, Kulice, Genomie, Morzeszczyna, Rzeżęcin, Borkowo, z osada młyńską, Rozbark, Bielawki i Wolsza ${ }^{127}$. Parafian spowiadających się na Wielkanoc było 1121 osób, Nie było innowierców i Żydów z wyjątkiem jednej wdowy, akatoliczki. Akuszerki były poinstruowane o sposobie udzielania sakramentu chrztu, Organista mieszkający na miejscu uczył także dzieci, mają odpowiednie wynagrodzenie. Przytułek nie miał własnego uposażenia i trzech, lub czterech, ubogich żyło z jałmużny, s. 246.

Opis zabudowań plebańskich i inwentarza, s. 246-247.

K r ó 1 ó w 1 a s. Kościół filialny parafii Nowa Cerkiew. Wiz. 8 listopada 1745 r. Opis świątyni wystawionej z tzw. pruskiego muru, niedawno naprawiana, a właściwie prawie nowa wystawiona, przez aktualnego zakonnika prepozyta. Nie przechowywano Najświętszego Sakramentu. Wykaz paramentów liturgicznych. Uposażenie proboszcza składało się z 2 łanów ziemi będących $\mathrm{w}$ dzierżawie i mesznego z wsi Królówlas. Był też łan ziemi, z czego pobierano roczny dochód. Nie było zabudowań plebańskich, s. 247-248.

Dekret reformacyjny dla parafii Nowa Cerkiew i Królówlas, s. 248-249.

W a 1 i c h n o w y. Wizytacja 23 października 1745 r. Świątynia stawiana w zewnątrz z muru, ale cienkiego, wewnątrz z pruskiego muru, pod wezwaniem św. Jana Chrzciciela, prawa patronatu królewskiego, Posiadała przywileje odpustowe. Nie było bractwa, jedynie różaniec o Matce Bożej i prawdopodobnie litania do Najświętszego Imienia Jezus, były odmawiane naprzemian z organistą, przed mszą świętą, w niedziele i święta. Świątynia nie posiadała własnego uposażenia, ale powiedziano, że dokumenty w tym względzie zaginęły, gdy kościół był w rekach innowierców. Opis wnętrza świątyni i trzech ołtarzy. Nie było żadnego kościoła filialnego, czy kaplicy, s. 251-252.

Wykaz paramentów liturgicznych, s. 252-254.

Proboszczem był Jan Küsing, dobrze spełniający swoje obowiązki, s. 254.

Opis uposażenia proboszcza z trzech łanów ziemi, ponadto innych jeszcze gruntów i domów, z których pobierano roczny czynsz, s. 254.

Do parafii należały wsie: Wielkie Walichnowy, Małe Walichnowy, Rozgarty i Kuchnia Królewska, s. 254.

Wykaz dokładny powinności,jakiepowinnybyć oddawane proboszczowi,a często nie są realizowane, s. 254-255.

Odpisy dokumentów z roku 1661 i z 1743 dotyczące uposażenia parafii, s. 255.

Parafian było nieco ponad 300 osób, byli także luteranie, którzy nie posiadali własnego zboru, ale mieli swój cmentarz do grzebania ciał we wsi Walichnowy Małe. Z innych jednak wsi chowali się na cmentarzu przy kościele parafialnym. Akuszerki były pouczone o swoich obowiązkach. Organista mieszkający w Walichnowach uczył zasad wiary i początków pisania i czytania, ale tylko w okresie zimowym. Nie było przytułku, s. 255-256.

${ }^{127}$ Lekcja niepewna i miejscowość niezidentyfikowana. 
Odpis dokumentu o uposażeniu parafii, z 12 VI 1703 r., w którym powoływano się na dawniejsze jeszcze zapisy, s. 256-260.

Inwentarz własności parafialnej, s. 260.

Dekret reformacyjny, s. 260-262.

P ą c ze w o ${ }^{128}$. Wizytacja 24 III 1746 r. Opis świątyni murowanej, jeszcze z czasów krzyżackich, teraz już znacznie zniszczonej. Była prawa patronatu królewskiego, pod wezwaniem Narodzenia Najświętszej Marii Panny. Były przywileje odpustowe, ale nie było żadnego bractwa, s. 263.

Uposażenie kościoła stanowił łan ziemi z nadania księcia Radziwiłła, ale nie było już dokumentu, posiadającego potwierdzenie królewskie. Grunt ten, przez dawnych proboszczów, za wiedza wizytatorów parafii, dano organiście, jako uposażenie. Ponadto były trzy domki, z których pobierano czynsz. Na parafię szła część opłat za pogrzeby, których wysokość tu wyszczególniono oraz ofiary do skarbony, s. 263-264.

Opis wnętrza świątyni, posiadającej pięć ołtarzy. Wykaz paramentów liturgicznych, s. 264-267.

Uposażenie proboszcza składało się z czterech łanów ziemi, zapisu1000 florenów na mszę, uczynionego przez dawnego proboszcza Babeckiego, uczynionego na mieście Gniew, oraz z dwóch domów dzierżawionych za czynsz, s. 267.

Do parafii należała wieś Pączewo i Wolental. Parafian spowiadających się było 380 osób, akatolików nie było, tylko jeden Żyd z żoną. Organista i nauczycielem zarazem był Stanisław Latoszewicz, który oprócz używania ziemi, jak to wyżej powiedziano, miał także wynagrodzenie od parafian. Przytułek nie miał własnego uposażenia. Opis zabudowań parafialnych i spis inwentarza, s. 267-269.

$\mathrm{C}$ z a r n y 1 a s ${ }^{129}$. Kościół w tej wsi od dawna należy jako filialny do parafii Pączewo. Murowany, z czasów krzyżackich, znacznie zniszczony. Prawo patronat należy do króla i nosi wezwanie św. Anny. Przywilej odpustowy przy ołtarzu św. Józefa. Bractwo św. Józefa. Kościół nie miał specjalnego uposażenia, a tylko ofiary z racji pogrzebów. Opis wnętrza i pięciu ołtarzy. Wykaz paramentów liturgicznych. Bractwo posiadała własny sprzęt, s. 269-272.

Parafia administrował proboszcz z Pączewa, odprawiając nabożeństwa niedzielne raz $\mathrm{w}$ jednej świątyni, raz w drugiej. Uposażenie stanowiły cztery łany ziemi oraz kilka domów, s. 272-273.

Wsie parafialne: Czarnolas, Zelgoszcz, folwark $\mathrm{Wda}^{130}, \mathrm{Krąg}^{131}$ oraz osada młyńska i karczma Wda. Wykaz innych powinności dla proboszcza. Parafian spowiadających się było 411 osób, 4 luteran w Zelgoszczy, oprócz mieszkańców dworu w Czarnymlesie, młynie i karczmie Wda. Żyd z rodzina, dzierżawiący karczmę w Czarnymlesie. Organista przyjeżdżał razem z proboszczem z Pączewa.

\footnotetext{
${ }^{128}$ Od tego miejsca pisała inna ręka.

${ }^{129}$ Wówczas pisano rozdzielnie: Czarny Las.

${ }^{130}$ Obecnie ośrodek samodzielnej parafii.

${ }^{131}$ Nie zidentyfikowano, chyba że chodzi o Krąg obecnej parafii Szlachta.
} 
Zabudowania parafialne spłonęły przez przyjściem obecnego proboszcza i nie zostały odbudowane. Nie było przytułku, s. 273-274.

Odpis przywilejukróla JanaKazimierza dlaparafiiPączewo, wystawiony wWarszawie, dnia 28 II 1654 r., zamieszczonego w lustracji generalnej Prus z 11664 r., s. 2274-275.

Dekret reformacyjny dla parafii Pączewo i kościoła filialnego Czarnolas, s. 276-281.

Li g n o w y ${ }^{132}$. Wizytacja odbyta 24 litego 1746 r., przez Augustyna Klińskie$\mathrm{go}^{133}$, dziekana chełmińskiego i archidiakona pomorskiego, z polecenia biskupa włocławskiego Walentego Czapskiego. Opis murowanej świątyni we wsi królewskiej Lignowy, patronatu królewskiego, pod wezwaniem św. Marcina i św. Małgorzaty. Przywilej odpustowy dla Bractwa Różańcowego. Było jeszcze drugie bractwo Najświętszego Imienia Jezus, s. 283-284.

Uposażenie kościoła pochodziło z ofiar składanych przy pogrzebach, z pewnej ilości ziemi dzierżawionej przez mieszkańców wsi Lignowy i kilku domków, czym zajmowali się Witrykusi, s. 284-285.

Opis wnętrza świątyni i czterech ołtarzy, spis wyposażenia w paramenty liturgiczne, stosunkowo bogatego, s. 285-288.

Proboszczem był Adam Kos, kanonik włocławski ${ }^{134}$, który rezydował jednak we Włocławku, w parafii utrzymując wikariusza Józefa Żurkałowskiego. Ten spisywał metryki chrztów i ślubów, zaś księgę zmarłych i rachunkową, prowadził jeden z witrykusów, czyli Prowizorów. Dochód proboszcza stanowiły cztery łany ziemi i siedem mórg łąk, położonych na tzw. Nizinach, co dzierżawił aktualnie szlachcic Zawadzki, s. 289.

Wsie parafialne: Lignowy, Bursztyn, Janiszewo i Pomyje, które oddawały meszne. Ponadto proboszcz miał połowę z opłat przy pogrzebach. Katolików spowiadających się było 488, Żydów nie była, luteran natomiast 183, ale nie mieli swojego zboru, udając się do wsi Rudno w parafii Garcz, gdzie mieli swoja szkolę, spełniająca role ich świątyni. Akuszerki były wystarczająco pouczone. Organista rezydował przy parafii, ale nie miał żadnego specjalnego funduszu, ani ziemi, i był wynagradzany ze skarbony kościelnej. Dawniej miał jeszcze z opiekę nad zegarem kościelnym, ale od lat czterech zegar był zepsuty. Przytułku aktualnie nie było, ale dawne wizytacje o nim wspominały, a w domku wystawionym na jego placu mieszkał jeden z wieśniaków, płacąc czynsz, s. 289-291.

Opis zabudowań parafialnych i inwentarz, s. 291.Bractwo Różańcowe i Najświętszego Imienia Jezus oraz ich uposażenie i posiadane przedmioty i obrazy, s. 292.

S z p r u d o w o. Kościół filialny parafii Lignowy, a raczej kaplica. Opis jej stanu, dosyć dobrego. Nosiła wezwanie św. Judy Tadeusza. Nie było żadnego specjalnego uposażenia dla nie, bractwa, ani przywilejów odpustowych, s. 293.

${ }^{132} \mathrm{~W}$ księdze napisano Libnowy.

${ }^{133}$ Biogram tego archidiakona zob. C h o d y ń s k i, Katalog, s. 391-393.

${ }^{134}$ Biogram tego kanonika zob. C h o d y ń s k i, Katalog, s. 426-427. 
Opis wnętrza świątyni oraz znajdujących się tam paramentów liturgicznych i innego sprzętu. We wsi tej mieszkali też luteranie, którzy posiadali tu swój zbór. Akuszerka umiała chrzcić dzieci. Organista przyjeżdżał parafii. Nie było przytulku. Był jeden domek, w którym mieszkał krawiec Tomasz Latoszewicz, oraz drugi zamieszkały przez wdowę Mariannę Sierakowską, s. 293-296.

Odpis z tablicy znajdującej się w świątyni w Lignowych, gdzie podano szereg wiadomości o początkach kościoła parafialnego i jego uposażeniu, s. 297-299.

G a r c. Wizytacja 8 lutego 1746 r. Kościół Zbudowany w czasach krzyżackich, murowany, w dobrym stanie. Prawo patronatu należało do monarchy. Nosił wezwanie Niepokalanego Poczęcia Najświętszej Marii Panny. Do naprawy świątyni byli zobowiązani parafianie. Opis świątyni. Były przywileje odpustowe. Bractwo Różańcowe, które posiadało własne uposażenie., s. 301-302.

Opis wewnętrznego wyposażenia, ołtarzy oraz wykaz paramentów liturgicznych, s. 302-205.

Proboszczem był Józef de Mathy, od wielu lat tu nie rezydujący. Z ustanowienia Konsystorza Gdańskiego w parafii zastępuje go Tomasz Klinowski, który też dzierżawił uposażenie proboszcza i corocznie odsyłał należność (300 florenów pruskich) proboszczowi przebywającemu we Francji (in Gallia), s. 305.

Uposażenie proboszcza składało się z czterech łanów, ale aktualnie były to trzy łany oraz z łąki, s. 305-306.

Wsie parafialne: Garcz, Gręblin, Rudno, Międzyłęż. Wiernych spowiadających się na Wielkanoc było 450, zaś luteran około 1600 osób, którzy posiadali w Rudnie swój zbór, gdzie w języku niemieckim nauczał ich pastor. Mieli oni tam swój cmentarz, jednak innowiercy z wsi Garcz chowali się na wyznaczonym miejscu cmentarza parafialnego. Organista, który miał swój dom i ogród, pobierał jeszcze wynagrodzenie ze skarbony kościelnej i z różnych opłat, tu wyliczonych. . Nie było przytułku, Akuszerki były Należycie pouczone o swoich powinnościach, s. 306-307.

Opis zabudowań plebańskich, s. 307.

Odpis dekretu z dnia 7 sierpnia 1744, wystawionego przez Konsystorz Gdański, w sprawie zobowiązań parafian do dbałości o świątynię, s. 307-309.

Dekret reformacyjny, s. 310-214.

R a j k o w y. Wizytacja 17 marca 1746 r. Opis świątyni pod wezwaniem św. Bartłomieja, w dobrym stanie. Opis ołtarzy. Był przywilej odpustowy. Bractwo Różańcowe posiadające własne uposażenie. Świątynia posiadała na swoje utrzymanie pewne grunta, zwane Skrzypice oraz opłaty z pogrzebów wg określonych stawek, s. 315-316.

Opis wnętrza kościoła oraz wykaz wyposażenia, s. 316-319.

Proboszcz Andrzej Jankowski, rezydujący na miejscu. Uposażenie jego składało się z czterech łanów ziemi, ale w rzeczywistości były one znacznie uszczuplone, ponieważ dwa pola w okolicach Gręblina i Rudna, a także jeszcze inne dodatki były mało urodzajne. Proboszcz miał też dla siebie cześć z pogrzebów oraz pewien dochód ze mszy i od bractwa, s. 319. 
Do parafii należała jedynie wieś Rajkowy, z której pobierał meszne. Miał też jeszcze prawo do innych świadczeń od parafian. A tych, mających obowiązek spowiedzi wielkanocnej było około 300 osób. Luteran było trzech, ale ich żony i dzieci byli katolikami. Żydów nie było. Akuszerki poinstruowane o swoich powinnościach. Przytułku, ani uposażenie dlań nie było. Organista Paweł Lipiński, który był jednocześnie rektorem szkoły, odpowiednio wynagradzany. Opis tego wynagrodzenia, dosyć znacznegol, s. 319-321.

Opis zabudowań plebańskich i inwentarza, s. 321-322.

Dekret reformacyjny, s. 322-326.

D z i e r ż ą ż n o. Wizytacja 6 listopada 1745 r. Opis murowanej świątyni, której kolatorami byli prałaci i kanonicy włocławscy, noszącej wezwanie św. Jakuba Większego. Przywilej odpustowy dla ołtarza św. Jozefa. Świątynia nie posiadała własnego uposażenia, jedynie domek, z którego był rocznie niewielki czynsz. Z dawnego zwyczaju na kościół szła część opłat z racji pogrzebów, s. 327-328 .

Opis wnętrza kościoła z trzema ołtarzami. Spis paramentów kościelnych, s. 328-329.

Proboszcz Paweł Redmerowski, rezydujący na miejscu. Miał jako uposażenie cztery łany ziemi, dwa domy, w jednym mieszkał owczarz, a z drugiego był czynsz. Do parafii należała wieś Dzierżążno, Brody Polskie i Gogolewo oraz kolonia przy młynie w kierunku Gniewu położonym. Wiernych spowiadających się było 296 , A z powodu, ze parafia ta była patronatu duchownego, nie było tu żadnych akatolików. Akuszerki były odpowiednia pouczone. Organista był wynagradzany ze skarbony kościelnej, ale nie mając własnego domu, dzieci nie uczył. Dawniej był łan ziemi na jego utrzymanie, ale poprzedni zarządcy parafią i komisarze z ramienia kapituły włocławskiej ziemie tę rozdali kmieciom. Przytułku nie było ani funduszu na ten cel, s. 329-330.

Zabudowania plebańskie i inwentarz, s, 330.

Dekret reformacyjny, s. 331-333.

$\mathrm{S}$ t a r o g a r d ${ }^{135}$ [Gdański]. Wizytacja 12 marca 1750 r. W tym mieście królewskim kościół murowany pod wezwaniem św. Mateusza Apostoła. Opis świątyni z dwiema kaplicami, w jednej jest bractwo Różańcowe, a druga nosi wezwanie św. Barbary, s. 335.

Proboszczem był Paweł Sikorski ${ }^{136}$, scholastyk włocławski, zaś zarządcą Tomasz Gliszczyński, wikariuszem natomiast Michał Greca, s. 335.

Były przywileje odpustowe, ale upłynął termin ich ważności. Bractwo Różańcowe z własnym uposażeniem. Do uposażenia kościoła należał dochód z browaru, ogród, czyli folwark, łan ziemi oraz ofiary do skarbony. Opis wnętrza świątyni z dziesięcioma ołtarzami. Bogate wyposażenie w paramenty liturgiczne, s. 336341 .

\footnotetext{
${ }^{135}$ Od tego miejsca pisała inna ręka.

${ }^{136}$ Biogram tego kanonika zob. C h o d y ń s k i, Katalog, s. 816-821.
} 
Uposażenie proboszcza w cztery łany ziemi, jeden łan przy kościele św. Jana, dziewięć domków, ale aktualnie nie wszystkie dawały dochód, Ponadto proboszcz miał dołączone kościoły filialne: w Nowej Wsi z czterema łanami i w Jabłowie także z czterema łanami. Ponadto pobierał meszne z wsi Sumino, Rokicin, Owidz, Barchanowy, Kolincz, Nowa Wieś, a także z kasy miasta Starogard oraz z Jabłowa i Kuczborowa. Wiernych komunikujących na Wielkanoc było 1037 osób. Innowiercy w swoim zborze $\mathrm{w}$ dwie niedziele miewali nabożeństwa $\mathrm{w}$ języku niemieckim, a w jedną w języku polskim, s. 341-343.

Akuszerki były należycie poinstruowane. Organista był jednocześnie zakrystianinem, a także uczył dzieci czytania i pisania oraz podstaw wiary, za co otrzymywał stosowne wyposażenie. Przytułek znajdował się poza murami przy bramie wiodącej do Nowej Wsi. Posiadał własne uposażenie, s. 343-344.

Wykaz różnego inwentarza, tak należącego do bractw, jak, zdaje się i parafialnego, s. 344-347.

Opis stanu drewnianego kościoła w Nowej Wsi, znacznie zniszczonego. Posiadał on nieco własnych sprzętów kościelnych i paramentów liturgicznych, s. 347-348.

Opis stanu murowanego kościoła w Jabłowie jego wyposażenie i uposażenie, s. 349-351.

Dekret reformacyjny dla parafii w Starogardzie i dla kościołów filialnych, s. 352356.

Odpis ugody zawartej dnia 13 grudnia 1749 r., pomiędzy proboszczem starogardzkim i oficjałem gdańskim Piotrem Pawłem Sikorskim, a magistratem starogardzkim, s. 359-361.

Z b 1 e w o. Wizytacja dnia 9 marca 1750 r. Wieś królewska w starostwie borzechowskim, pod wezwaniem św. Michała Archanioła. Prawo patronatu należało do monarchy. Opis świątyni. Arcybractwo Różańcowe zaprowadzone w 1732 r., s. 363-364.

Wykaz paramentów liturgicznych, s. 364-368.

Uposażenie proboszcza stanowiły cztery łany gruntu i ogrody oraz prawo połowu Ryn w jeziorze. Ponadto pobierał meszne z wsi Zblewo, Borzechowo, Iwiczno, Radziejewo, Nieradowo, Białachowko, Piłka Lipska, Bląmfeld, kaliska, Młyńsk, Czubek, Iwickie Piece, nowa kolonia zwana Cys, Zawada, Nieraddowska, nowa kolonia Czarne, Libicki i Huta Borzechowska, Białachowsko Radziejewskie, Piekiełko, s. 368-370.

Dom dla nauczyciela dobry z ogrodem. Przytuliku nie było. Było nieco Żydów i luteran, s. 370.

Proboszcz Michał Wenda, s. 370.

Dekret reformacyjny, s. 371-375.

L u b i c h o w o. Wizytacja 9 marca 1750. Była tam nowo wystawiona świątynia drewniana, pod wezwaniem św. Jakuba i św. Barbary, prawa patronatu królewskiego. Opis jej stanu. Nie było żadnego bractwa. Kościół nie posiadał specjalnego uposażenia, jedynie składano ofiary do skarbony. Był to, od czasów nie- 
pamiętnych, kościół filialny parafii Zblewo, chociaż w nim przechowywano nim Oleje święte i była chrzcielnica, jednak Najświętszego Sakramentu nie przechowywano. Skromne wyposażenie w paramenty liturgiczne, s. 377-379.

Wsie należące do parafii, to: Lubichowo, gdzie wymieniono nawet nazwiska mieszkańców i ilość posiadanej przez nich ziemi, Osowo, Ocypel, ${ }^{137} Z$ Zielona Góra, Budy i Pustkowia Zielonogórskie oraz nowe kolonie Miały, Mościska, Lipieńki, Szyszkowy i karczma ${ }^{138}$, Bietowo, Steklin. Podano tu także należności dla parafii z poszczególnych wsi, a nawet gospodarstw. Było 16 Żydów oraz luteranie w ilości jednej czwartej całej parafii, ale nie podano ilości wiernych. Akuszerki były pouczone o sposobie udzielenia chrztu. S. 379-381.

Wykaz innych paramentów i szat liturgicznych oraz ksiąg, s. 381-382.

Proboszcz ten sam co w Zblewie, Józef Michał Wenda, dobrze spełniający swoje obowiązki, s. 382.

Uposażenie proboszcza w cztery łany ziemi. Organisty nie było, ani przytułku, który dawno popadł w ruinę, zaś należący do niego ogród przejęli wieśniacy. Zabudowania plebańskie wymagają remontu, s. 382-283.

Dekret reformacyjny dla parafii Lubichowo z dnia 9 III 1750 r., s. 384-388.

C z e r s k. Wizytacja 16 lipca 1746 r. Wieś w starostwie tucholskim. Świątynia drewniana, dosyć dobrego stanu, ale nieraz huragany wyrządzały pewne szkody. Opis stanu kościoła noszącego wezwanie św. Marii Magdaleny. Prawo patronatu należało do monarchy. Kilka przywilejów odpustowych. Nie było osobnego uposażenia na utrzymanie świątyni. Opis stanu wnętrza kościoła. We wsi Ł ą g znajdował się kościół filialny, ale będzie opisany osobno, s. 389-391.

Wykaz naczyń i paramentów liturgicznych, s. 391-392.

Proboszcz Szymon Plutowski. Uposażenie jego składało się z czterech łanów ziemi i innych nieruchomości, s. 393.

Miejscowości parafialne, dosyć liczne, bo były kolonie i pustkowia, a mianowicie: Czersk i folwark oraz młyn Czersk, Niezorawa, Mokre, Lutom, Malechin, Łosiny, Twarożnica, Korcze Kolonia, Ostrowy, folwark Uboga, Zapendowo, Retel, kolonie Sienica, Konigort, Kłodnia, Przyjaźnia, Gotelp, Gartki, Ostrowite, Budziska, Klonownica, Lubna, Cys, Bielawy. Wiernych korzystających z sakramentów na Wielkanoc było około 1500 osób, Żydów 3 domy, luteran około 50, ale swojego zbory nie posiadali. Za obecnego proboszcza nawróciło się 31 osób. Były dobre akuszerki. Organista miał nowy dom. Uczył dzieci, gdy ich przysyłano. Nie było przytułku, s. 393-395.

Zabudowania plebańskie i wykaz inwentarza żywego i martwego, s. 395.

Ł ą g. Wizytacja tego samego dnia, co w Czersku. Kościół filialny drewniany, pod wezwaniem Narodzenia Najświętszej Marii Panny, patronatu królewskiego. Bractwa nie było. Nie przechowywano Najświętszego sakramentu, ale była chrzcielnica i oleje święte. Opis ołtarzy i wykaz paramentów liturgicznych. Para-

\footnotetext{
${ }^{137}$ Nazwę tę pisano nieraz łącznie, nieraz oddzielnie.

${ }^{138}$ Nazwy karczmy trudno odczytać.
} 
fią administrował proboszcz z Czerska. Miał on na utrzymanie cztery łany ziemi. Należały do parafii wsie: Łąg, Prusy, Będźmierowice, młyn zawada, Zimne Zdroje, Złe Mięso, Tleniny ${ }^{139}$. Sam kościół nie posiadał specjalnego uposażenia, jedynie część dzieloną od pogrzebów z proboszczem. Organista nie rezydował na miejscu, zabudowania plebańskie były stare i żadnego inwentarza nie było, s. 396-399.

Oświadczenie Jakuba Zalewskiego, że był winien pewna sumę pieniędzy kościołowi w Czersku, pożyczona od proboszcza Szymona Plutowskiego, s. 399.

Dekret reformacyjny dla parafii Czersk i Łąg, s. 401-405.

Wyciąg z testamentu uczynionego10 II $1750 \mathrm{r}$. w Chełmży, na trzysta florenów, na rzecz kościoła w Niedamowie oraz dla kościoła w Lubiszewie i Czersku, za odprawianie mszy za ofiarodawców. Testament podpisała Anna Klińska, w obecności świadków. Wierny odpis tego aktu dokonano Czersku 23 IV 1750 r., s. 406-407.

K i s z e w a. Wizytacja 6 maja 1750 r. Opis stanu kościoła parafialnego w Kiszewie i filialnego w Polaszkach. Świątynia w Kiszewie, nowo zbudowana, drewniana, fundacji Skorzewskich, pułkownikowstwa królewskiego ${ }^{140}$, pod wezwaniem św. Marcina i św. Walentego. Prawo patronatu należało do króla. Stan świątyni i otoczenia dobry. Opis wnętrza kościoła. Świątynia filialna w Polaszkach. Innych kaplic nie było, s. 409-410.

Proboszcz Jakub Deduszki. Obowiązki wikariusza spełniali zakonnik dominikanin Tomasz Cicheński. Wiernych zobowiązanych do sakramentów wielkanocnych było 614 osób. Znaczna była ilość akatolików. Duszpasterstwo było sprawowane wzorowo. Akatolicy posiadali swój zbór we wsi Nowe Polaszki, gdzie był ich minister nauczający w języku niemieckim. W Nowej Kiszewie był także zbór ewangelicki, gdzie nauczał nauczyciel ich szkoły. Proboszcz i wikariusz dawali dobry przykład, s. 410-412.

Opis ołtarzy w świątyni, s. 412.

Uposażenie proboszcza stanowiły cztery łany ziemi, czynsz z trzech domów. Zabudowania plebańskie nowe. Pewien dochód był także z zamku kiszewskiego. Wsie parafialne oddające meszne: Stara Kiszewa, Malki Górne, Wygonin, Bartel, Studziennice, Konarzyny, Bartoszowy Las, Kiszewa Nowa, Nowe kolonie: Goluń, Fleszarstwo, Gołuń, Ciągadło, Babie, Nierybno, Struga, Żubrek, Barłogi, Strzelki, Krowia Góra, Chwarzno, Pałubino, Bukowiec, Olpuch, osada młyńska Ruda, Boże Pole, Turowo, Bulawiec, osada młyńska Bukowiec i osada młyńska Nowa Kiszewa, s. 412-414.

Szkoła i dom dla organisty, który pobierał stosowne wynagrodzenie oraz pewną ilość ziemi. Było mieszkanie dla wikariusza. Bractwa nie było. Aktualny proboszcz wystarał się o przywilej odpustowy, s. 414.

Wykaz paramentów liturgicznych, dosyć bogaty, s. 414-417.

\footnotetext{
${ }^{139}$ Lekcja niepewna.

${ }^{140}$ Tak można przetłumaczyć odnośny zapis w księdze.
} 
Opis kościoła filialnego w P o l a s z k a c h, starego, w pruski mur, znacznie zniszczonego, ale który ma być odbudowany. Nie był konsekrowany, a nosił wezwanieśw. Mikołaja. Uposażenie proboszcza składało sięzjednegołany ziemiidziesięcin. Wykaz wyposażenia w paramenty liturgiczne, dosyć bogate, s. 417.419.

Dekret reformacyjny dla kościoła parafialnego w Kiszewie i filialnego w Polaszkach, s. 420-427.

P o g ó d k i. Wizytacja 3 marca 1750 r. Wieś należąca do opactwa w Pelplinie. Świątynia cała murowana, fundowana przez Tomasza Franciszka Czapskiego, koadiutora chełmińskiego w 11715 r., pod wezwaniem św. Piotra i Pawła, poświęcona przez samego fundatora, ale nie konsekrowana. Prawo patronatu należało do opata z Pelplina, Ignacego Czapskiego, jednocześnie sekretarza królewskiego. Opis świątyni i jej wnętrza. Bractwo Aniołów Stróżów, s. 429-430.

Uposażenie kościoła płynęło z czynszów płaconych przez dzierżawców, z dwóch łanów ziemi położonych w Kośminie i w Kleszczewie i innych jeszcze, czym zarządzali witrykusi z prepozytem. Akatolicy nie posiadali swojego zboru. Chowali się wyznaczonym dla nich miejscu w Czernikowie, inni zaś w Pogótkowach poza cmentarzem. Akatolików było 205 osób, zaś katolików spowiadających się 893 osoby. Akuszerki były odpowiednio poinstruowane, s. 430-431.

Prepozytem byłzakonnik cysterskiAleksander Białachowski, rezydujący i sprawujący dobrze nabożeństwa. Wikariuszem zaś był Wojciech Raczyński, też cysters, s. 432.

Uposażenie proboszcza stanowiły cztery łany w Kośminie, w Kleszczewie także cztery łany oraz domy wydzierżawiane. Meszne pobierał z wsi Kleszczewo, Jaroszewy, Głodowo, Więckowy, Kosmin, Junkrowy, Czernikowy, Malikowy, mała kolonia Malarek, kolonia Waldówko, kolonia Jezierze, folwark Pogódki. Dawniej była też wieś Kobyle. Ponadto znajdowały się jeszcze małe kolonie Liszewko, Bukowiec, Zajeziorki, Zawada, Ryte, Milonki, Brzeszczek. W jeziorze Popówek był wolny połów ryb. Aktualny proboszcz wystawił nowe zabudowania plebańskie. Organista, mający łan ziemi, uczył dzieci. Miał też jeszcze inne wynagrodzenie, s. 432-434.

Opis ołtarzy w świątyni. W parafii, we wsi Kleszczewo, był kościół filialny, który spłonął w 1653 r., tak iż nie ma nawet tam cmentarza, jedynie stoi krzyż, s. 435.

Wykaz paramentów liturgicznych, dosyć bogaty, obrazów, krzyży, innych sprzętów znajdujących się w świątyni i książek, s. 435-442.

Spis własności bractwa Aniołów Stróżów, s. 442-444.

Dekret reformacyjny dla parafii w Pogódkach, s. 445-451.

Wykaz sum należnych kościołowi w Pogódkach, znajdujących się u wierzycieli, s. 453.

K o k o s z k o w y. Wizytacja 15 marca 1750 r. Kościół inkorporowany do konwentu [dominikanów] w Tczewie przez biskupa Gniewosza przed około stu laty, murowany, pod wezwaniem św. Barbary. Bractwo różańcowe zaprowadzone 
przez dominikanów. Opis stanu wewnętrznego świątyni i jej wyposażenie, s. 457-459 .

Świątynia nie posiadała własnego uposażenia, poza zapisanymi pewnymi sumami na procent oraz składanymi ofiarami. Zarządzali tym, wespół z proboszczem, witrykusi, s. 459.

Jak wynika z zapisów dawnych z 1633 r., których odpis znajdował się w posiadaniu aktualnego proboszcza Ambrożego Kowalkowskiego, były dawniej kościoły filialne, posiadające we wsi Linowiec cztery łany ziemi, zaś w Szpęgawsku trzy łany. W Szpęgawsku, Stanisław Konarski, kasztelan chełmiński, za zgodą biskupa włocławskiego Krzysztofa Szembek i dziekana starogardzkiego Wojciecha Piatkowskiego, urządził kaplicę przy swoim dworze, s. 459-460.

Wykaz paramentów liturgicznych, s. 460-461.

Uposażenie proboszcza pochodziło z otrzymanego musznego, s. 461.

Uposażenie kościoła, według zapisu z 1632 r. składało się z czterech łanów, ale aktualnie $z$ dwóch łanów ${ }^{141}$, s. 461.

Wsie oddające proboszczowi meszne: Kokoszkowy, Szpęgawsk, Ciecholewy, Zduny, Linowiec, Bączek, Krąg, Żabno, s. 461-462.

Inne wiadomości o parafii, między innymi katolików spowiadających się było 515 osób, W Ciecholewach były dwie rodziny żydowskie, luteranie zaś, docyc liczni mieszkali głównie we wsi Krąg. Organista uczył dzieci podstaw czytania i pisania oraz zasad wiary. Był przytułek, ale podopieczni żyli z Jałmużny. Był wszczęty proces o dzwon, znajdujący się dawniej przy nieistniejącym kościele w Szpęgawsku, który zabrali mieszczanie ze Starogardu, zapewne luteranie i zawiesili go w swoim zborze, s. 462-463.

Dekret reformacyjny dla kościoła w Kokoszkowach, s. 464-467.

K 1 o n ó w k a. Wizytacja 19 marca 1746 r. Świątynia murowana, pod wezwaniem św. Katarzyny, której kolatorem była dziedziczka Klonówki, z Kalksztejnów Pawłowska, żona Jana Pawłowskiego, sędziego Michałowskiego. Świątynia była ostatnio starannie naprawiana przez Jerzego Wolff, kanonika warmińskiego, wówczas dziedzica Klonówki. Bractwo Różańcowe i Najsłodszego Imienia Jezus, założone w 11732 r. przez Jana Kantego Rychłowskiego, chorążego sieradzkiego, ówczesnego męża Pawłowskiej, z zapisem 500 florenów Nadorach Rajkowy. Świątynia nie posiadała specjalnego uposażenie, jedynie ofiary przy pogrzebach i do skarbony. Opis wnętrza koscioła. Znajdowały się relikwie św. Katarzyny. We dworze znajdowała się kaplica prywatna, gdzie, za zgodą ordynariusza miejsca, można było sprawować mszę, s. 469-471.

Wykaz paramentów liturgicznych, w tym także należących do bractw, s. 471-473 .

Proboszcz Marcin Franciszek Szela, s. 473.

Uposażenie proboszcza składało się z czterech łanów ziemi, w 1719 r. odmierzonych przez Mariannę Kosowę, wojewodzinę chełmińską, gdy proboszczem

${ }^{141}$ Jest to ponowny, w stosunku do strony 459, zapis o uposażeniu kościoła. 
był Szymon Ćwikliński. Były też zapisy pewnych sum, tu wyliczone, s. 473-474 .

Do parafii należały wsie oddające meszne: Rywałd, Lipieńki i Klonówka. Parafian spowiadających się na Wielkanoc było 367 osób, zaś luteranami była rodzina dzierżawcy na folwarku Lipieńki, którzy chowali się na wyznaczonym, od dawna miejscu na cmentarzu. Organista uczył dzieci. May przytułek, w właściwie chatka, zaś podopieczni żyli z jałmużny. Nie było żadnego inwentarza plebańskiego, zaś zabudowania plebańskie znacznie zniszczone, teraz Częściowo naprawiane, s. 474-475.

Dekret reformacyjny, s. 475-479.

B o b o w o. Wizytacja 22 marca 1746 r. Świątynia stara, jeszcze z czasów krzyżackich. Nosiła wezwanie św. Wojciecha i Wniebowzięcia Najświętszej Marii Panny. Prawo patronatu należało do króla. Bractwo Różańcowe zaprowadzone przez dominikanów, staraniem aktualnego proboszcza, uposażone przez łowczego koronnego zamojskiego, ówczesnego starostę gniewskiego, s. 481.

Opis uposażenie świątyni, na co składały się jeden łan ziemi, nadanej przez starostę Olbrachta Radziwiłła, kilka domów oraz pewne zapisy sum na procent. Opis stanu wnętrza świątyni., s. 482-483.

Wykaz paramentów liturgicznych, dosyć bogatych, s. 483-485.

Proboszcz Wojciech Piątkowski, dziekan starogardzki, s. 485.

Uposażenie proboszcza stanowiły cztery łany ziemi, dwa domy dajace czynsz roczny oraz meszne ze wsi: Bobowo, Wysoka, Smoląg, Żabienki. Katolików spowiadających się było 466 osób, Żydów nie było, zaś do religii luterańskiej należało dwóch owczarzy z rodzinami. Akuszerki potrafiły chrzcić w nagłej potrzebie. Był organista, jednocześnie rektor szkoły, którego wynagradzała parafia. Przytułek istniał, posiadając fundusz zapisany dawniej przez księcia Radziwiłła. Zabudowania plebańskie, z całym wyposażeniem w 1742 r., ale staraniem obecnego proboszcza Zostały odbudowane. Inwentarz plebański skromny, s. 485-486.

$\mathrm{D}$ ą b r ó w k a. Kościół filialny parafii Bobowo i zapewne wizytowany tego samego dnia. Świątynia murowana, także z czasów krzyżackich, pod wezwaniem Podwyższenia Świętego Krzyża, patronatu królewskiego. Opis stanu świątyni i jej uposażenie, na co składał się łan ziemi danej przez księcia Radziwiłła, s. 487-488 .

Wykaz paramentów liturgicznych, ss. 488-489.

Uposażenie proboszcza składało się z czterech łanów ziemi, ale ta została wydzierżawiona. Do kościoła tego należała jedynie wies Dąbrówka, dawniej przez samych luteran zamieszkała, z wyjątkiem sołtysa, ale aktualnie prawie wszyscy się nawrócili. Zabudowania plebańskie znajdowały się w ruinie, s. 489.

Dekret reformacyjny, s. 489-493.

P i n c z y n. Wizytacja 16 marca 1750 r. Świątynia nowa, z drewna, wystawiona kosztem Skórzewskiego, starostę Kiszewskiego, z wieżą stawiana w pruski mur, pod wezwaniem świętej Elżbiety. Opis stanu wnętrza świątyni. Uposażenie 
specjalnego nie posiadała, jedynie połowę ofiar z pogrzebów, także od luteran oraz ofiary składane do skarbony. Bractwo św. Józefa. Przytułku nie było. Proboszcz, którego nazwiska ani imienia Anie podano, rezydował zawsze w parafii, wikariusza nie miał. Ponieważ parafia miała mały dochód, dzieci uczył organista. Luteran było na terenie parafii około 100 osób, ale nie było Żydów. Nie było też akuszerki. Dwa domy należące do parafii, proboszcz wydzierżawił, s. 495-496.

Opis wyposażenia świątyni i wykaz paramentów liturgicznych, s. 496-498.

Uposażenie proboszcza z czterech łanów ziemi oraz meszne z wsi: Pinczyn, Semlin, Góra, Piesienica ${ }^{142}$, Sucimin ${ }^{143}$. Ponadto nowe kolonie Pinczynem, Karpaty, folwark Bukowiec, folwark Suciminek, Nowy Dworzec, karczma Borowa i folwark Pałubinek, s. 498-500 ${ }^{144}$.

Dekret reformacyjny dla parafii Pinczyn, s. 501-503.

\section{Dekanat nowski (nowomiejski)}

N o w e. Wizytacja 13 października 1745 r. Świątyni murowana z czasów krzyżackich, jednak parafia erygowana w 1185 r. przez księcia pomorskiego Przemysława. Opis świątyni pod wezwaniem św. Mateusza Apostoła. Prawo patronatu należało do króla. Do naprawy świątyni było zobowiązane miasta, ale z powodu ubóstwa mieszczan, czyni się to z funduszy kościelnych. Były też inne zapisy, tu wymienione, potwierdzone przez komisje królewską w 1654 r., ale od czasów niepamiętnych, żaden dochód nie dochodził. Dawniej należał do parafii kościół filialny w Lubieniu, teraz nazywany kaplicą, pod wezwaniem św. Jakuba, ale bardzo zniszczona i zdaje się, że w niej nie odprawiano, jeżeli nazwano ją ,spelunca latronum". Na przedmieściu Gdańskim znajdował się mały kościołek pod wezwaniem św. Grzegorza, też znacznie zniszczony, ale z fundacji nieżyjącego mieszczanina Bartłomieja Szabłowskiego, co miesiąc powinna się w nim odprawiać msza za duszę fundatora. Bractwo Różańcowe, zaprowadzone w 1641 r., staraniem prepozyta i dziekana nowskiego Piotra Góreckiego, posiadające swoje znaczne uposażenie, tu dokładnie wyliczone, s. 505-507.

Kościół miał pewne uposażenie z zapisu 400 florenów z 1601 r. przez niejaka Czerwińska oraz z zapisów innych, tu wyliczonych, s. 507-508.

Inwentarz paramentów liturgicznych, bardzo bogaty, w tym także kilka książek, s. 508-511.

Proboszcz i dziekan Andrzej Józef Majowski ${ }^{145}$, kanonik kamieniecki, rezydujący na miejscu, prowadzący duszpasterstwo z wikariuszem Augustynem Chylickim, s. 511.

Uposażenie proboszcza składało się z czynszów za wydzierżawiane domy, z pobożnych zapisów, a także z musznego płaconego z miasta Nowe, z zamku i folwarku Kończyce oraz z wsi: Milewo, Zawada i Labętki, Kamionka, Bochlin, Ko-

\footnotetext{
${ }^{142}$ Miejscowość niezidentyfikowana.

${ }^{143}$ Pewnie teraz w parafii Zblewo.

${ }^{144}$ Protokół ten robi wrażenie, jakby nie był dokończony.

145 Tak napisano to nazwisko.
} 
zielec, Trel, Morgi i Zapusty. Były też kolonie, zapewne nowe, w lasach należących do Nowego się znajdujące, jak Zdroje, Małe Osiny, Zabijek, Głodowo, Poledzawy, Montasek, Rzeczyca, Ciemnylas. Ogółem katolików spowiadających się na Wielkanoc było 850 osób, luteran 600 , nawróconych od 1730 r. 28. Żydów nie było. Luteranie nie mieli swojego zboru, jedynie szkołę i trzech nauczycieli we wsiach Trel, Morgi i Rychlewa. Chowali się na własnych cmentarzach. Akuszerki były wystarczająco pouczone o sposobie udzielania chrztu. Organista Stanisław Roszankowski, rektor szkoły Jerzy Cymer, znający język polski i niemiecki, a nawet łacinę, s. 511-514.

Przy kościele znajdował się przytułek, posiadający pewne własne uposażenie, a przy nim mały kościółek św. Jerzego, poza murami miasta, odbudowany przez aktualnego prepozyta (zdaje się, że imieniem Roch), s. 514.

Zabudowania plebańskie murowane, ich opis oraz wykaz inwentarza, s. 514,

Opis starożytnego kościółka św. Jerzego, znajdującego się przy bramie gdańskiej, odbudowanego, czy raczej restaurowanego ostatnio staraniem prepozyta Rocha, s. 514-515.

Dekret reformacyjny, w tym także oddzielnie dla kościółka św. Jerzego, s. 515-520.

K o m o r s k. Wizytacja 1 października 1745 r. Kościół, po spaleniu się, w 1684 r. zbudowany pod wezwaniem św. Bartłomieja i św. Józefa, z drewna, staraniem nieżyjącego już, ówczesnego proboszcza Piotra Robakowskiego. Prawo patronatu należało do miejscowego ordynariusza. Cztery bractwa, a mianowicie: św. Aniołów Stróżów, zaprowadzone przez Michała Kolmer, scholastyka kruszwickiego w 1678 r. z pozwoleniem Michała Kotarzewicza, przełożonego polskiej prowincji zakonu paulinów, Najświętszego Imienia Jezus i Różańcowe zaprowadzone w 1717 r. przez Marcina Glinieckiego, przeora dominikanów z Chełmna, św. Jana Nepomucena, zaprowadzone w 1740 r. przez ówczesnego proboszcza Andrzeja Robakowskiego. Opis uposażenia tych bractw oraz uposażenie kościoła. Prowizorami w parafii byli Franciszek Kasper i Szymon Wiśniewski. Stan wnętrza świątyni i jej wyposażenia oraz ołtarze, s. 521-522.

Wykaz paramentów liturgicznych i ksiąg, s. 522- 524.

Proboszcz Józef Muradowicz, kanonik kruszwicki i sekretarz biskupa ordynariusza, przy biskupie przebywający, a za niego obowiązki duszpasterskie spełniał wikariusz Mikołaj Kuchtowski, s. 524.

Uposażeniem proboszcza składało się z czterech łanów ziemi, pięciu domów, z których pobierano czynsz oraz domku dla szkoły we wsi Pastwisko, także dającej dochód. Meszne oddawano z wsi parafialnych: Wielki Komorsk, Warlubie, Rolewo, Mały Komorsk. Inne wsie to Pastwisko, Piaski, Rolewko, Rozgardy. Parafian przystępujących do sakramentów wielkanocnych było 542 osoby, luteran 150 , nawróconych 41. Akuszerki należycie pouczone. Organista by zarazem nauczycielem uczącym podstawowych zasad wiary i czytania. Mieszkał w części przytułku, ale nie użytkował już lana ziemi, o czym wspominała dawna wizytacja, ale był wynagradzany z funduszów kościelnych. Przytułek odbudowany staraniem biskupa Krzysztofa Szembek, s. 524-525. 
Zabudowania plebańskie z drewna, opis folwarku plebańskiego i inwentarza pozostawionego po śmierci proboszcza Robakowskiego, s. 525-526.

Dekret reformacyjny, s. 526-527.

B z o w o. Wizytacja 10 października 1745 r. Kościół patronaty królewskiego w starostwie grudziądzkim, wystawiony niedawno w pruski mur, pod wezwaniem św. Małgorzaty. Opis wnętrza świątyni i jej wyposażenia, s. 528.

Wykaz paramentów kościelnych, s. 528-529.

Parafia ta była filialną dla parafii Komorsk i tamtejsi kapłani ja obsługiwali. Uposażenie proboszcza składało się z czterech łanów ziemi, łąki zwanej Kawel i jeziora Głowianek, a także kilku domów, z których był czynsz roczny. Ziemia była w dzierżawie. Szkoła zbudowana przez proboszcza Robakowskiego. Do parafii należały wsie: Bzowo, Grupa Wysoka, Grupa Niska, Osiek, Piła,Fletowa, Bzowko. Katolików przyjmujących już sakramenty było 308 osób, menonitów 236, luteran zaś 203 osoby. Zniszczony przytułek nie został odbudowany. Organista był opłacany ze skarbony kościelnej, s. 529-530.

Dekret reformacyjny, s. 530-531.

P i en i ą ż k o w o. Wizytacja 15 października 1745 r. Świątynia murowana, pod wezwaniem św. Jana Chrzciciela, fundowana przez Jana Oleskiego, dziedzica z Ostrowitego. Opis wnętrza świątyni i jej wyposażenia. Bractwo Św. Aniołów Stróżów, zaprowadzone w 1642 r. przez Piotra Góreckiego, prepozyta z Nowego, staraniem Zuzanny Oleskiej. Osobnego uposażenia bractwo nie posiadało. Parafia specjalnego uposażenia nie posiadała, jedynie z okazji pogrzebów część akcydensu, s. 533-534.

Wykaz paramentów liturgicznych, s. 534-535.

Proboszcz Paweł Kamrowski. Uposażenie skromne z czynszu z jednego domu oraz z musznego pobieranego z Pieniązkowa, Luchowa, Smarzewa, Dąbrówki, Półwsi, Czerwińska, Kolimagi oraz w innych, jak Ostrowite, Murowany Młyn, Stary Młyn, Młynik, Murowana Karczma, Potułowo, Pustkowie Wiosło. Katolików spowiadających się było 345 osób, luteran 30, nawróconych 5. Akuszerki były pouczone o sposobie udzielania sakramentu chrztu. Organista uczył dzieci i był należycie wynagradzany. Przytułek, który z powodu starości poprzedniego proboszcza Mateusza Jarzębińskiego uległ ruinie, nie został jeszcze odbudowany, Ubodzy żyli z jałmużny. Plebania drewniana została wystawiona kosztem aktualnego proboszcza, $z$ drewna danego przez dwór Ostrowite. Wykaz inwentarza plebańskiego, s. 535-538.

Dekret reformacyjny, s. 538-540.

B a r ło ż n o. Wizytacja 11 listopada 1745 r. Świątynia murowana, pod wezwaniem św. Marcina, patronatu królewskiego. Opis wnętrza kościoła i wyposażenie. Bractwo św. Izydora, zaprowadzone w 1648 r. na uposażenie kościoła był łan ziemi, dany przez króla Władysława IV, wolny od wszelkich ciężarów oraz inne jeszcze dochody, s. 541-542.

Wykaz paramentów liturgicznych i ksiąg, s. 542-544. 
Proboszcz Wojciech Niesiołowski. Plebania dosyć wygodna. Uposażenie proboszcza dosyć bogate, składające się z kilku łanów ziemi, położonych w kilku miejscach, tu opisane, łąk oraz z musznego pobieranego z wsi parafialnych: Barłożno, Mirotki, Młyn Lipiagóra, Młyn Piła, Młyn Kierwałd, folwark Mirotki, folwark Lipiagóra i Mirotki, folwark Kierwałd, Gąsiorki. Katolików spowiadających się byłom600 osób, luteran zaś 12. Organista zima uczył dzieci i był za to odpowiednia wynagradzany, Był przytułek, ale bez własnego uposażenia i ubodzy żyli z jałmużny. Wykaz inwentarza plebańskiego, s. 544-545.

Dekret reformacyjny, s. 545-547.

S k ó r c z i G r a b o w o ${ }^{146}$. Wizytacja 9 listopada. Świątynia murowana pod wezwaniem Wszystkich Świętych i Niepokalanego Poczęcia Najświętszej Marii Panny. Prawo patronatu należało do króla. Bractwo św. Anny. Opis wnętrza świątyni i jej wyposażenia. Do tego kościoła należała parafia Grabowo, niżej opisana, i kaplica a Osieku, drewniana, pod wezwaniem św. Rocha, s. 549-550.

Wykaz paramentów liturgicznych, s. 550-552.

Proboszcz Michał Ignacy Rogaczewski. Uposażenie proboszcza składało się z sześciu łanów ziemi w Skórczu i z mesznego pobieranego z wsi: Skórcz, Wielbrandowo, dworu Osiek. Ponadto do parafii należały wsie: Karzenek, Kozie, Skrzynia, Kasperus, Bledno ${ }^{147}$, Radogoszcz. Była też fundacja „Blazeviana”, dwóch tysięcy florenów na mieście Gniew lokowana, oraz inne sumy, dające dochód, s. 552.

Uposażenie kościoła z czterech domów oraz z pewnych zapisow, s. 552.

Uposażenie bractwa, s. 553.

Katolików spowiadających się było 700 osób, akatolików 17, Żydów 12. Akuszerka należycie poinstruowana. Organista uczył dzieci, s. 553.

Plebania dosyć wygodna, ale zniszczona przez niedbalstwo w naprawach. Przytułek aktualnie naprawiany. Było sześć wdów podopiecznych, żyjących z jałmużny. Wykaz inwentarza plebańskiego, s. 553.

Kościół filialny w Grabowie, wystawiony w pruski mur. Opis jego stanu. Wyposażenie w paramenty liturgiczne. Uposażenie dla kościoła nie było, natomiast proboszcz miał cztery łany ziemi, ale były w dzierżawie. Przytułek, gdzie ubodzy żyli skromnie z z braku uposażenia, s. 553-554.

Wiadomość o zapisie na ten kościół przez niejakiego Kitowskiego, s. 554-555 .

Dekret reformacyjny dla obydwóch kościołów, s. 555-558.

L a 1 k o w y. Wizytacja 27 marca 1746 r. Kościół murowany, jedynie dach, chociaż naprawiany w 1740 r., w niektórych miejscach wymagał remontu. Opis dokładny świątyni, pod wezwaniem św. Barbary, prawa patronatu monarszego. Bractwo św. Barbary, ale własnego uposażenie nie posiadało. Kościół specjalnego własnego uposażenia nie posiadał, ale były dwa małe domy, z których był czynsz,

\footnotetext{
${ }^{146}$ Miejscowość Grabowo dopisano inną ręką.

${ }^{147}$ Lekcja niepewna.
} 
zapis na światło przed Najświętszym Sakramentem oraz opłaty z pogrzebów. Składkami zarządzali prowizorzy. Opis wnętrza świątyni i jej wyposażenia. Kaplica prywatna w dworze Rynkówka, z prawem odprawiania mszy, s. 559-563.

Wykaz paramentów liturgicznych, bogaty, w tym ponad trzydziestki książek teologicznych, s. 563-567.

Proboszcz Franciszek Juda Tadeusz Uzdowski. Dawniej na uposażenie było sześć łanów ziemi, aktualnie zaś jedynie cztery. Meszne oddawały wsie: Lalkowy, Rynkówwka, Frąca, Smętówka, Kopytkowo, Włosienica, Udziera, oraz kolonie Bukowiny, Cisowy i Jeżewnica nie oddawały musznego. Liczba katolików przyjmujących sakramenty wynosiła 702 osoby, dwie rodziny żydowskie, zaś luteran było 16 rodzin. W każdej wsi była akuszerka potrafiąca chrzcić w razie konieczności. Organista uczący także dzieci, Adam Witkowski, posiadający odpowiednie uposażenie. Przytułek, zbudowany w 1720 r. z ofiar różnych ofiarodawców, ale podopieczni żyli z jałmużny, chociaż dwa pomieszczenia były dzierżawione, a dochód szedł na naprawy przytułku, s. 567-569.

Zabudowania plebańskie odbudowane przez aktualnego proboszcza i inwentarz plebański, s. 569-570

Dekret reformacyjny, s. 570-576.

P ł o c h o c i n. Wizytacja 12 października 1745 r. Świątynia drewniana, a właściwie w pruski mur wystawiona w 1761 r. przez Aleksandra Czapskiego, podkomorzego malborskiego i Franciszka Aleksandra Jasińskiego, sędziego ziemskiego puckiego. Kościół ten, jeszcze nie konsekrowany, był pod wezwaniem św. Wawrzyńca i św. Katarzyny. Prawo patronatu należało do Stanisława Jasińskiego, właściciela dóbr Płochocin, a także częściowo do dziedzica dóbr Bąkowo. Bractwo Różańcowe założone w 1727 r., staraniem Franciszka Jasińskiego, posiadające własne uposażenie. Kościół parafialny nie posiadał specjalnego uposażenia, jedynie z pogrzebów, według panującego zwyczaju. Opis wnętrza świątyni i jej wyposażenia. W Bąkowie znajdowała się kaplica z obrazem Matki Bożej, otoczonym szczególna czcią, s. 277-578.

Wykaz paramentów liturgicznych w tym także kilkanaście książek, s. 578580 .

Proboszcz Grzegorz Józef Szuwalski. Jako uposażenie było kilka domów dających czynsz, pewne zapisy na msze, trzy łany ziemi w Płochocinie oraz meszne z wsi: Płochocin, Bąkowo, Lipienki, osady młyńskie Bokowo i Borowiec i wieś Krzywin. Wsie parafialne: Płochocin, Płochocinem, Krzywin, Bąkowo, Lipienki, młyny Bąkowo i Borowiec oraz pustkowia Stara Huta, Nowa Huta, Nowa Huta Homer. Wiernych spowiadających się było 350, nie było Żydów, zaś luteranie w kilku wsiach, chociaż nie podano ich liczby. Nawróconych 7 osób. Akuszerki potrafiły chrzcić. Organista uczył także dzieci i posiadał należyte uposażenie. Był przytułek, s. 580-582.

Zabudowania plebańskie zbudowane przez aktualnego proboszcza w $1724 \mathrm{r}$. i w następnych. Wykaz inwentarza plebańskiego, s. 582-583.

Dekret reformacyjny, s. 583-584. 
L u b i e ń. Wizytacja 9 października 1745 r. Świątynia murowana z czasów krzyżackich, ale wymagająca pilnej naprawy. Opis stanu świątyni. Była pod wezwaniem św. Jakuba Apostoła, zaś prawo patronatu należało do króla. Nie było bractw, zaś przywileje odpustowe się skończyły. Kościół nie posiadał specjalnego uposażenia, a luteranie i memmonici nie płacą nic z racji pogrzebów, chociaż byli zobowiązani do tego przez obecnego prymasa ${ }^{148}$, a przedtem biskupa miejscowego. Opis wnętrza świątyni i wyposażenia, s. 585-586.

Wykaz paramentów liturgicznych, s. 586-587.

Uposażenie proboszcza składało się z czterech łanów ziemi. Innowiercy, którzy korzystali z posługi proboszcza i powinni dawać wynagrodzenie, nie dawali nic, lub niewiele. Meszne oddawały wsie Mątawy, Zajączkowo Małe, ZajączkowoWielkie, Lubień Wielki, Lubień Mały, Targosz. W parafii byli memmonici i mieli swój dom modlitwy. Na terenie parafii było 85 luteran, 94 menonitów, katolików 50. Zydów nie było. Akatolicy mieli swoje szkoły w Mątwach, Zajączkowie, Lubieniu i w Tragoszu. Nie było pewności, czy akuszerki umiały chrzcić. Organista był wynagradzany przez proboszcza, s. 687-589.

Proboszcz Jerzy Miller. Zabudowania plebańskie, zwłaszcza dom proboszcza wymagały naprawy. Nie było właściwie inwentarza parafialnego, s. 589.

Dekret reformacyjny, s. 589-591.

K o ś c i e ln a J a n i a. Świątynia murowana pod wezwaniem Swiętej Trójcy, patronatu miejscowego dziedzica, aktualnie niejakiego Nieborskiego, starosty ciechanowskiego. Opis stanu zewnętrznego kościoła. Nie posiadał on specjalnego uposażenia. Opis wnętrza świątyni, s. 593.

Spis paramentów liturgicznych, s. 593-594.

Proboszcz Andrzej Kuchtowski. Uposażenie proboszcza z czterech łanów ziemi, trzech domów i procentu od zapisanej sumy 600 florenów. Meszne pobierał z wsi Kościelna Jania i folwarku Kościelna Jania, Folwarku i wsi Stara Jania, folwarku Kownatka, folwarku Bobrowiec, wsi Grabowiec i Leśna Jania, osady młyńskiej Słuchacz. Parafian spowiadających się 390, akatolików 2. Akuszerki potrafiły chrzcić. Organista był, ale specjalnego uposażenia nie posiadał i był wynagradzany ze skarbony kościelnej i z racji pogrzebów. Przytułku nie było, s. 594595.

Zabudowania plebańskie, które spaliły się w 1743 r., zostały odbudowane częściowo przez poprzedniego proboszcza, częściowo przez obecnego. Inwentarz plebański skromny, s. 595-596.

Dekret reformacyjny, s. 596-598.

Ł ę g o w o ${ }^{149}$. Wizytacja 12 marca 1745 r. Świątynia murowana, pod wezwaniem św. Mikołaja. Prawo patronatu należało do opata oliwskiego. Wykaz przywilejów odpustowych. Bractwa nie było. Kościół posiadał na swoje uposażenie cztery łany ziemi, co dawało roczny dochód po 15 florenów, z całości zaś 75 flo-

${ }^{148}$ Chodzi o Krzysztofa Szembeka (1667-1748), najpierw biskupa inflanckiego, potem poznańskiego, kujawskiego, a następnie arcybiskupa gnieźnieńskiego i prymasa.

${ }^{149}$ Obecnie w archidiecezji gdańskiej. 
renów ${ }^{150}$.Pozostałe dochody były ze skarbony. Opis wnętrza świątyni jej wyposażenia. Kościół parafialny w Różynach był afiliowany do parafii Łęgowo, ponadto kaplica we wsi Grebin ${ }^{151}$ należącej do konwenty oliwskiego. Opis wnętrza świątyni parafialnej, s. 599-600.

Spis paramentów liturgicznych, s. 600-603.

Uposażenie proboszcza składało się z dwóch łanów ziemi, dochodu z dzierżawionego domu, oraz pewne dochody płacone z łanów parafialnych. Meszne pobierał z Łęgowa i Grabina. Proboszcz Iwo Rowder, przeor konwentu oliwskiego, mającu tu swojego zastępcę „Pothonem Drews”, zakonnika. Do parafii należały wsie: Łęgowo, Skowarcz, Grabin i Muchen ${ }^{152}$. Katolików było 454, akatolików jedna rodzina, ale ich dzieci były katolikami. Akuszerka jedna, dobrze przygotowana. Organista uczący dzieci, posiadał dom i odpowiednie wynagrodzenia. Przytułku nie było, s. 603-605.

Zabudowania plebańskie dobre. Inwentarza nie było, s. 605.

R ó ż y n y. Kościół ten był dawniej parafialnym. Przez czas pewien znajdował się w rękach luteran, rewindykowany w 1614 r. przez biskupa włocławskiego Wawrzyńca Gembickiego i jako filialny złączony z parafia w Łęgowie. Aktualny biskup włocławski Walenty Czapski, za zgodą kapituły włocławskiej i po zatwierdzeniu tego porzez Stolicę Apostolską, odnowił unie tej parafii z parafia prowadzona przez cystersów Łęgowie. Opis świątyni odbudowanej częściowo kosztem opactwa oliwskiego, częściowo także z pomocą dzierżawcy dóbr Różyny Trembeckiej. Wykaz wyposażenia i paramentów liturgicznych. Administrował ta parafia proboszcz parafii Łęgowo, wyżej wspomniany. Uposażenie składało się z czterech łanów ziemi. Do parafii należały wsie Różyny, Skowarcz. W tej parafii było 138 katolików spowiadających się, luteran zaś 57 . Nauczyciel uczył dzieci, także akatolickich, s. 605-608.

Dekret reformacyjny dla obydwóch kościołów, s. 608-610.

Dekret specjalny dla kościoła w Różynach, s. 611-612.

K ł o d a w a. Wizytacja 3 marca 1774 r. Świątynia murowana, nowa, której budowę rozpoczęto w 1733 r., której kamień węgielny poświęcił Andrzej Reiss, proboszcz z Łęgowa, a budowę ukończono w 1735 r. Opis tego kościoła, pod wezwaniem św. Jakuba Większego. Prawo patronatu należało do opata z Lądu, który był zobowiązany do podniesienia kościoła włodawskiego z ruiny. Bractwo Szkaplerza, ale bez własnego uposażenia. Kościół nie posiadał także specjalnego funduszu, jedynie z ofiar z racji pogrzebów oraz zbiórki do skarbony. Opis wnętrza świątyni., s. 613-614.

Wykaz paramentów liturgicznych, bardzo bogaty, a także inwentarz paramentów należący do bractwa, s. 614-620.

Proboszcz Adam Zaremba, ale chociaż miał jeszcze parafie Trąbki, to rezydował w Kłodawie, a w drugiej parafii utrzymywał zastępcę. Uposażenie składało

\footnotetext{
${ }^{150}$ Tak podano w księdze.

${ }^{151}$ Nie zidentyfikowano.

${ }^{152}$ Miejscowość niezidentyfikowana.
} 
się z dwóch łanów ziemi, z czego połowę stanowił las oraz jeden dom dający czynsz. Meszne pobierał z wsi Kłodawa i osady młyńskiej, Zła Wieś, Żukczyn i osada młyńska, osada hutnicza Hamer, Kleszczewo, Ulkowy, Zakrzewo, Kłobuczewo, Kaczki, Trąbki Małe. Liczba wiernych komunikujących wynosiła 420 osób, Żydów nie było, luteran zaś 74 osoby, ale nie posiadali oni swojego zboru, chowali się na cmentarzy parafialnym w miejscu osobnym. Akuszerki potrafiły chrzcić. Organista był jednocześnie nauczycielem. Nie było przytułku. Ani funduszu dla niego, s. 620-622.

Dom plebański stary i wymagający naprawy, inne zabudowania stawiane przez aktualnego proboszcza. Wykaz inwentarza plebańskiego, s. 622.

Dekret reformacyjny, s. 623-626.

W i e 1 e. Wizytacja dnia 12 kwietnia 1750 r. We wsi królewskiej kościół drewniany, pod wezwaniem św. Mikołaja, patronatu królewskiego. Dwa bractwa, a mianowicie św. Józefa i św. Anny, nieposiadające własnego uposażenia. Opis wnętrza świątyni624-630.

Wykaz paramentów liturgicznych, z zaznaczeniem tego, co za aktualnego proboszcza sprawiono, s. 630-631.

Proboszcz Marcin Jan Lendowski ${ }^{153}$, nie posiadający innego beneficjum. Uposażenie proboszcza składało się z pięciu łanów ziemi i pięciu domów, z których był czynsz. Meszne pobieral z wsi: Wiele, wieś i folwark Karszyn, Górki, Dąbrowa, Przytarnia, Borsk, Miedzno, Lisewie Bąk, Wojtal Odry, Osowo, Piechowice, Kliczkowo, Broda, kolonia Wdzydze. Wiernych spowiadających się było około 1000 osób, Żydów nie było, akatolików we wsi odry było 20, ale zboru swojego nie mieli. Akuszerki były poinstruowane. Dom proboszcza bardzo mizerny, inne zabudowania dobre. Organista, uczący dzieci, miał swoje uposażenie, 631-634.

Dekret reformacyjny, s. 635-642.

B r u s y i kościół filialny L e ś n o. Wieś królewska Brusy posiadała kościół drewniany pod wezwaniem Wszystkich Świętych, patronatu królewskiego. Opis świątyni, która jednak specjalnego uposażenia nie posiadała, jedynie z ofiar i z pogrzebów. Stan wewnętrzny i wyposażenie, s. 643-645.

Rektorem kościoła był Szymon Koliński od 1706 r. Uposażenie składało się $\mathrm{z}$ czterech łanów ziemi. Wsie parafialne z których też oddawano meszne: Brusy, Kosobudy, czyszkowy, Lubnia, Zalesie, Męcikał, Turowiec, Turowiec, Giełdon, Okręglik, Pokrzywno, Spiorewnik ${ }^{154}$, Czarniż, Drzewicz, Rolnik, Żabno, Chełmy Małe, Czarnowo, Czapiewice, Główczwice, Glino, Chełmy Wielkie. Wiernych spowiadających się około 1700 osób, Była jedna rodzina żydowska w Czapiewicach, ale on zmarł, o ona wróciła do matki, akatolików także jedynie około 3 czy 4 osoby. Akuszerki dobrze pouczone. Zabudowania plebańskie dobre. Organista uczył dzieci, s. 645-647.

\footnotetext{
${ }^{153}$ Lekcja niepewna.

${ }^{154}$ Może obecna Spiera.
} 
Spis paramentów liturgicznych i innych sprzętów, a także książek oraz własności bractwa, s. 647-651.

Kościół filialny w Leśnie. Jego stan i uposażenie. W 1710 r. został on całkowicie odbudowany. Nosił wezwanie Świętego Krzyża, prawo patronatu miał monarcha. Nie posiadał specjalnego uposażenia, jedynie mały domek z czego był niewielki dochód. Bractwa żadnego nie było. Opis wnętrza świątyni, ale nie podano, czy była drewniana, czy murowana, s. 651-653.

Spis skromnych paramentów liturgicznych, s. 653-654.

Uposażenie proboszcza składało się z czterech łanów ziemi orazz musznego z wsi: Lesno, Lendy, Trzebuń, Raaduń, osady młyńskie Kaszuba i Parczyn, Windorp, Kruszyn, Skoszewo, Peplin, Laska, Werszyn, Wysoka, Orlik, Prondzanka ${ }^{155}$. Wiernych spowiadających się było około 810 osób, innowierców i Żydów nie było. Akuszerki umiały chrzcić. Organista był zarazem nauczycielem. Przytułku nie było. Zabudowania plebańskie, odbudowane przez aktualnego proboszcza, utrzymywał dzierżawca. Inwentarza żadnego nie było, s. 654-656.

Dekret reformacyjny dla parafii Brusy i filii Leśno, s. 657-661.

\section{Dekanat świecki}

Ś w i e c i e. Wizytacja 28 lutego 1750 r. Miasto królewskie. Kościół prawa patronatu królewskiego. Murowany, pod wezwaniem św. Stanisława, w 1755 r. częściowo uszkodzony z powodu wylewu rzeki, ale będzie naprawiony. Cztery bractwa, a mianowicie: Świętej Trójcy, Różańcowe, św. Izydora, św. Anny. Z dawnej wizytacji wynikało, że było jeszcze bractwo literackie. Podano tu bliższe dane o bractwach. Istniały też liczne cechy rzemieślnicze, organizowane na wzór bractw religijnych. Informacje o uposażeniu kościoła w Świeciu i o utrzymaniu przytułku dla ubogich były zawarte w postanowieniu biskupa Krzysztofa Szembek i podane do wiadomości przez ich wywieszenie w zakrystii. Opis wnętrza świątyni i ołtarzy, s. 663-667.

Wykaz paramentów liturgicznych, bardzo bogatych, s. 667-672.

Proboszcz Wawrzyniec Behan1 ${ }^{156}$, stary, ale posiadający wikariusza, z którym spełniają posługi duszpasterskie. Kaznodzieja był jeden z zakonników bernardynów. Wikariusz Jan Maurzycki. Wsi należących do parafii było 14. Wszystkich, tak katolików, jak i akatolików było około 1160 osób, z czego czwarta część to akatolicy, a ponadto 30 menonitów. Katolicy wszyscy spowiadali się na Wielkanoc. Żydów nie było. Akatolicy mieli swoje nabożeństwa we własnych szkołach, gdzie po niemiecku je odprawiali. Akatolicy, oprócz menonitów, chrzcili się i zawierali małżeństwa w parafii katolickiej. Nawróconych za obecnego proboszcza było 26 osób. Szkół nieemieckich było pięć, a mianowicie w: Wiąg, czaple, Ostrowo, Bratwin i Swolno Niemieckie. Akuszerki byłu dobrze pouczone. Organista miał dobre uposażenie, s. 672-674.

Uposażenie kościoła, prawdopodobnie i razem z tym proboszcza składało się

\footnotetext{
${ }^{155}$ Nie zidentyfikowano

${ }^{156}$ Lekcja niepewna,
} 
z dwóch łanów ziemi i dziesięcin, czy innych powinności z wsi: Przechowo, folwark i osada młyńska Przechowo, Solnowka, Stolno, Skarszewy, Kozłowo i osada młyńska, dwór Sartowice, CzapleWielkie, Morska, Bratwin, Stolno Polskie, Stolno Niemieckie, Michale, Wiąg, Marzy Nowe, Marzy Stare, osada młyńska Święta, Mniszek, s. 674-765.

Kościół w Świeciu posiadał liczne fundacje, s. 675.

Wykaz wotów srebrnych, s. 675.

Spis tabelaryczny funduszy kościoła parafialnego w Świeciu sporządzony na dzień 30 kwietnia 1725 r., na podstawie autentycznych dokumentów, s. 676-681.

Opis przytułku większego odbudowanego przed około 24 laty przez radcę Kryspina Becher, domu dla ubogich fundowanego przez Kazimierza i Katarzynę Rogalskich, s. 682.

Opisy domu dla wikariusza, szkoły i domu plebańskiego z inwentarzem, s. 682-683.

Opis kościoła [filialnego] w Świętem, s. 683.

Dekret reformacyjny dla kościoła w Świeciu i Świętem, s. 685-694.

J e ż e w o. Wizytacja 20 marca 1726 r. Świątynia z prezbiterium murowanym, zaś nawa drewniana, pod wezwaniem Trójcy Świętej, prawa patronatu biskupa włocławskiego. Bractwa nie było. Kościół nie posiadał specjalnego uposażenia z wyjątkiem zapisu niewielkiej sumy n procent $\mathrm{i}$ opłat z pogrzebów. Opis stanu wnętrza świątyni i ołtarzy, s. 605-607.

Wykaz paramentów liturgicznych, s. 607-700.

Proboszcz Jan Józef Szota. Uposażenie proboszcza składało się pięciu łanów ziemi oraz łąki, zwanej „Xieża Łączka” i czterech domów, dających czynsz roczny. Meszne oddawały wsie: Jeżewo, Maszewo, Białe, Piskarki, Belno, Ostowo, Lipna Wielkie, Lipiecko Małe, Krompiewice, Buczek. Czersk, Jaszcz, Buśna, Laskowice, a ponadto kolonie nowe Skrzynki, Langno, Huta, osada młyńska Bedlenek, Kołówka, Długoleszcz, Buszmenki, Nowawieś, skąd jednak musznego nie pobierano. Parafian spowiadających się było około 582, oprócz szlachty i ich sług, w liczbie około 30 osób. Luteran było około 250 osób, majźć swoje domy modlitwy we wsiach Buczek, Krompiewice, Czersk, Buśna i Białe, a chowali się na swoich cmentarzach w wymienionych wsiach. Trzy rodziny żydowskie. Akuszerki były odpowiednia pouczone. Organista jednocześnie uczył dzieci i miał odpowiednie wynagrodzenie, s. 700-702.

Opis zabudowań plebańskich, starych i inwentarza. Była też pasieka parafialna, wydzierżawiona bartnikowi, s. 702-703.

Dekret reformacyjny, s. 703-706.

Odpis uchwały sejmiku pruskiego (lauda) w Toruniu 3 października z $1616 \mathrm{r}$. o nie tolerowaniu w Prusach Żydów, s. 707.

Odpis podobnej uchwały podjętej w Grudziądzu 16 czerwca 1647 r., s. 708.

O s i e. Wizytacja 31 marca 1746 r. Świątynia, po spaleniu się z powodu nieostrożności i nie zgaszenia świec, w $1714 \mathrm{r}$. poprzedniej, z całym wyposażeniem i dzwonami, została odbudowana, jako drewniana. Prawo patronatu należało do 
monarchy, a nosiła wezwanie Znalezienia Świętego Krzyża. Nie było bractwa. Nie było specjalnego uposażenia kościoła, z wyjątkiem jednego domu dającego czynsz i opłat z pogrzebów. Opis wnętrza świątyni i ołtarzy, s. 709-710.

Wykaz paramentów liturgicznych, s. 710-712.

Proboszcz Michał Poleszka. Miał uposażenie z czterech łanów ziemi, czterech domów dających czynsz. Ten proboszcz zapisał nas mieście Świecie 1500 florenów, aby jego następcy odprawiali za jego duszę i za innych w czyśćcu, każdego tygodnia mszę $\mathrm{w}$ sobotę oraz jeszcze inne $\mathrm{z}$ tego tytułu zobowiązania. Meszne oddawano z wsi: Osie, Miedzno, Brzeziny, osady młyńskie Żur i Tleń, Krzyńciska, Pruskie, dwór Wierzchni i wieś, Stara Rzeka, Oski Piec. Wiernych spowiadających się było 360, luteran 90, którzy mieli swoja szkołę i cmentarz oraz trzy rodziny żydowskie. Był organista, Przytułku nie było, s. 712-714.

Zabudowania plebańskie nowe. Inwentarz własny proboszcza ma przejść na własność parafii, s. 714.

Dekret reformacyjny, s. 714-717.

D r z y c i m. Wizytacja 1 kwietnia 1747 r. Świątynia drewniana, przez poprzedniego proboszcza Kamieniewicza zewnątrz obita deskami, wewnątrz zaś, ponieważ też był zły jej stan, przez obecnego proboszcza w 1742 r. wyłożona tzw. pruskim murem i deskami. Opis stanu świątyni i jej dwóch kaplic. Nosiła wezwanie Wszystkich Świętych i Oczyszczenia Najświętszej Marii Panny, główna patronką zaś była św. Maria Magdalena. Prawo patronatu należało do króla. Bractwa nie było. Uposażenie kościoła pochodziło z opłat za pogrzeby i zbiórek, za co odpowiadali Witrykusi mateusz Kruczek, i Stefan Fabrun z Drzycimia. Bartnicy dobrowolnie oddawali 12 funtów wosku. Opis wnętrza świątyni i ołtarzy, s. 718720 .

Wykaz paramentów liturgicznych, s. 724.

Proboszcz Marek Antoni Makulski, kanonik łęczycki, utrzymujący tu zarządcę Tomasza Chmielewskiego. Na uposażenie składały się cztery łany i jeszcze dwa łany, pochodzące jeszcze z czasów krzyżackich z 1366 r., co zostało potwierdzone przez królów polskich. Odnośny dokument jest tu przytoczony. Ponadto było jeszcze kilka domów na czynsz. Wsie, płacące meszne były następujące: Drzycim, Gacki, Wetwie, Sierosław, Lniano, Lnianko, Sierosławek, Ryszka, Wyry, Rowiennica, Dulsk, Lubochin, Lubodziesz, Dąbrówka, Jastrzębie, Zalesie, Drzemiona, Mszano, Spławie, Siemkowo. Jeziorki. Ponadto należał do parafii Grodek oraz kolonie Humer, Mux, Dąbrowa, Grzybek, Polka, Kłosta, Rowieński Most, oraz folwarczki Brzęczek i Polowiec, nie oddające musznego. Wiernych spowiadających się było 1144, trzy rodziny żydowskie. Ponadto było tu około 30 rodzin memmonitów we wsi Jeziorki, sprowadzeni tu w roku 1727, za zgodą ówczesnego proboszcza drzycimskiego, na podstawie przywileju króla z $1660 \mathrm{r}$. określającego zachowanie się przedstawicieli innych wyznań. Ci menonici założyli w Jeziorkach swoją szkołę. Luteran zaś było ogółem około 40 rodzin we wsiach Ubodziesz, Dąbrówka i Dulsk. Organista był, wynagradzany jednym łanem ziemi i ze skarbony kościoła, mieszkając z pomieszczeniu przytułku. Ubodzy w przytułku żyli z jałmużny, s. 724-728. 
Stan zabudowań plebańskich i inwentarz, s. 728.

Dekret reformacyjny, s. 729-732.

Ś 1 i w i c e. Wizytacja 20 czerwca 1746 r. Świątynia drewniana i jej stan zewnętrzny. Była pod wezwaniem św. Katarzyny i patronatu królewskiego. Bractwo Opatrzności Bożej. Kościół nie posiadał specjalnego uposażenia, ani zapisów, jedynie ofiary ze skarbony zbierane przez witrykusów Franciszka Kuszmerek, Franciszka Plaza i Jana Żurawskiego oraz opłaty z racji pogrzebów. Opis wnętrza świątyni i ołtarzy, s. 733-734.

Wykaz paramentów kościelnych, s. 734-736.

Proboszcz Jan Józef Łęgowski. Uposażenie jego było małe, bo jedynie z opłat za pogrzeby, kolędy, składki wielkanocnej i mesznego z wsi: Sliwice, Lińsk, Trzepnicy, Kuniny, Łążek, Śliwiczki, osady młyńskie Śliwiczki i Loboda oraz Osówka. Były też kolonie Osieczna, Lesk, Zdroje, Szlachta, Rosochata, Króg, Klocek, jezioro Okuniny, Laski, Krowna, Biała, Woziwoda, Linowek, Zdrojna, Starzyska, Brzeźno, rzepnica, Zekcz, s. 736-738.

Opis skromnego uposażenia kościoła i stan zabudowań plebańskich. Wiernych spowiadających się było około 800 osób, Żydów nie było, zaś luteranie mieli tu 5 rodzin. Akuszerki wystarczająco pouczone. Organista Jan Pachowski nalezzycie wynagradzany. Przytułku nie było Nie dokonano tu wpisu stanu inwentarza, bo jest on spisany w księdze dziekańskiej, s. 738-739.

Dekret reformacyjny, s. 740-743.

Ł ą k i e. ${ }^{157}$ Wizytacja 22 czerwca 11746 r. Wieś benedyktynek chełmińskich z kościołem drewnianym. Opis zewnętrznego stanu świątyni. Nosił on wezwanie św. Bartłomieja i był patronatu wyżej wspomnianych zakonnic. Były przywileje odpustowe. Bractwa brak. Kościół nie posiadał specjalnego uposażenia, jedynie ofiary do skarbony i z pogrzebów. Opis stanu wewnętrznego świątyni i ołtarzy, s. 744-745.

Wykaz paramentów liturgicznych, s. 745-747.

Proboszcz Jan Hypnowski ${ }^{158}$. Jego uposażenie składało się z trzech łanów ziemi. Meszne było z wsi: Łąkie, Różanna, Stążki, Korytowo, Branica. Wiernych spowiadających się było 224 osoby, Żydów nie było, zaś akatolicy znajdowali się w Korytowie i Głuszycach. Akuszerki były należycie poinstruowane. Organista Stanisław Rutkowski, uczył także dzieci, s. 747-748.

Stan zabudowań plebańskich. Inwentarza nie było, s. 748.

Dekret reformacyjny, s. 749-750.

Pr z y s i e r s k. Wizytacja 23 czerwca 1746 r. Świątynia drewniana, niedawno odnowiona. Stan zewnętrzny. Nosiła wezwanie św. Wawrzyńca i była patronatu królewskiego. Były przywileje odpustowe. Bractwo Różańcowe zaprowadzone w 1732 r. posiadające zapisany przez Teresę z Konopackich Kruszyńską, kaszte-

\footnotetext{
${ }^{157}$ Obecnie parafia Polskie Łąki.

${ }^{158}$ Lekcja niepewna.
} 
lanową gdańską, pewne uposażenie. Odpis tego zapisu. Świątynia specjalnego uposażenie nie posiadała, jedynie ofiary z pogrzebów i ofiar do skarbony zbieranych przez witrykusów Jakuba Piotrowskiego i Marcina, niepodanego imienia. Stan wewnętrzny świątyni i ołtarze, s. 751-753.

Wykaz paramentów liturgicznych, s. 754-755.

Proboszcz Andrzej Józef Hersztowski.. Uposażenie proboszcza składało się z ziemi, opisanej, ale nie podano dokładnie wielkości oraz d domów, które były w dzierżawie. Do parafii należały wsie oddające meszne: Przysiersk, Konopat Polski, Wyrwa, Drozdowo, Bukowiec, Pniewno, Biechówko, Biechowo, Budyń, Jarzębieniec, Bramka, Kawęczyn. Wsie Gawroniec, Konopat Niemiecki, Terespole musznego nie oddawały. Wiernych spowiadających się było 600 osób, sporo innowierców w niektórych wsiach, dokładnie wyliczonych. O Żydach nie wspomniano. W przytułku było 5 podopiecznych, żyjących z jałmużny. Organista Adam Awnerowski posiadający wystarczające uposażenie. Akuszerki były pouczone, s. 755-757.

Stan zabudowań plebańskich dobry. Dokładny wykaz inwentarza, ss. 758759.

Dekret reformacyjny, s. 760-763.

G r u c z n o ${ }^{159}$. Wizytacja 6 czerwca 1746 r. Świątynia murowana i jej opis zewnętrzny. Nosiła wezwanie św. Jana Chrzciciela, a prawo patronatu należało do wikariuszy katedry gnieźnieńskiej, która to parafia, z przywileju arcybiskupa Jarosława [Skotnickiego], z 1354 r., za zgodą ówczesnego biskupa włocławskiego Macieja [Gołańczewskiego], im została inkorporowana.. Wykaz przywilejów odpustowych. Bractwo Aniołów Stróżów, założone w 1641 r. Kościół nie posiadał specjalnego uposażenie, jedynie ofiary z racji pogrzebów i z ofiar do skarbony. Opis stanu wewnętrznego kościoła i ołtarzy, s. 765-768.

Wykaz paramentów liturgicznych, s. 768-772.

Proboszcz Wojciech Woldański. Jego uposażenie z czterech łanów ziemi, trzech domów dających dochód, tu przedstawiony. Wsie oddające meszne: Dwór i osada młyńska Gruczno, Parlin, osada młyńska Zurowo, Małociechowo, Bagniewo, Luszkowo, Więckowo, Poledno składające się z części królewskiej i szlacheckiej, Dworzyńska, Kossowo, Krostkowo, Niedźwiedź, Kępa Rostkowska, Przewo. Do parafii, jako filia należała parafia Topolno ze swoimi wsiami, skąd proboszcz w Grucznie pobierał pewien dochód. Ponadto z zapisu niejakiej Zapędowskiej, szlachcianki z Poledna, uczynionego w 1723 r. był procent 5 od sta z sumy 500 florenów, co w 11735 r. przeniesiono na dobra Głuszyce z przeznaczeniem na mszę w każdą sobotę i to przed głównym ołtarzem. Parafian spowiadających się było 555, akatolicy, w liczbie nie podanej byli i mieli swoją szkołę i miejsce do chowania się. Żydów nie było. Akuszerki zostały wystarczająco pouczone przez obecnego proboszcza. Organista był. Był przytułek, ale bez własnego uposażenie. Podopiecznych pięciu żyjących z samej jałmużny, chociaż Stanisław Pi-

${ }^{159}$ Pisano wówczas Groczno. 
woński, starzec, oznajmił, iż był zapis dochodu na każdy rok w sumie 10 florenów z wsi Luszkowo, ale pobierał to proboszcz, s. 772-775.

Opis zabudowań plebańskich i wykaz inwentarza, 775-776.

Dekret reformacyjny, s. 777-780.

N i e w i e ś c i n. Wizytacja 8 czerwca 1746 r. Świątynia drewniana, zbudowana staraniem nieżyjącego już dziedzica dóbr Niewieścin, Pawła Wolskiego. Opis wyglądu zewnętrznego. Nosiła wezwanie Świętej Trójcy, zaś prawo patronatu należało do Grzegorza Niewieścińskiego, aktualnego dziedzica Niewieścina. Specjalnego uposażenia kościoła dnie było, jedynie z ofiar składanych z racji pogrzebów i z zapisu dokonanego w 1673 przez Fabiana Niewieścińskiego, na ręce prowizorów kościoła Wojciecha Przywidzkiego i Franciszka Ostrowickiego, na sumę 1000 złotych polskich. Opis wnętrza świątyni i ołtarzy, s. 781-783.

Wykaz paramentów liturgicznych, s. 783-8785.

Proboszcz Walenty Kostrzyński. Posiadał pewne uposażenie z zapisu z dnia 1745 r. dokonanego przez Grzegorza i Ludwikę z Czapskich Niewieścińskich, a także z dwóch łanów ziemi i łąkami doń należącymi. Meszne zaś pobierał z wsi: Niewieścin, Mroczyn, Pruszcz, Zbrachlin, Soponin, Kozielec, Cieleszynek i Wałdowo. Parafian spowiadających się było 477 osób, luteran 10 rodzin i jedna rodzina żydowska. Akuszerki pouczone, Organista był, s. 785-789.

Prowizorami Kocioła aktualnie byli Wojciech Jagiello i Grzegorz Zytkowski. Była tylko plebania, ale zniszczona. Innych zabudowań nie było, s. 789.

Dekret reformacyjny, s. 789-792.

S e r o c k. Wizytacja 8 czerwca 1746 r. Świątynia drewniana, dobrym stanie, fundowana przez nieżyjącego już Jana Franciszka Tuchotkę. Opis zewnętrznego stanu. Nosiła wezwanie św. Apostołów Szymona i Judy Tadeusza i była patronatu królewskiego. Było bractwo Różańcowe, które z fundacji Aleksandra Remigiusza Powalskiego miało zapis na 600 florenó3w, zabezpieczony na dobrach wsi Łaszewo, z czego proboszcz, pobierając rocznie 24 floreny, był zobowiązany w każdy piątek odprawiać mszę, na ubogich w przytułku należało oddawać florenów 8 , zaś na kościół szły 4 floreny. Drugi zapis był uczyniony przez dawnego proboszcza Pawłowskiego, oficjała bydgoskiego, wynoszący 200 florenów pruskich, z czego w każdy poniedziałek proboszcz miał odprawiać msze za członków bractwa. Świątynia specjalnego uposażenia nie posiadała, tylko ofiary z pogrzebów i z ofiar do skarbony, czym zarządzał Witrykusi Jakub Gawski, wespół z proboszczem, zaś organista prowadził rachunki składek. Opis stanu wewnętrznego świątyni i wyposażenia, s. 793-795.

Wykaz paramentów liturgicznych, s. 795-798.

Proboszcz Bartłomiej Trechowski, mający 36 florenów od bractwa i meszne z wsi Serock, Jasiniec i osady młyńskiej Jasiniec, Stary Jasiniec, Glinki, Łowinek, Brzeźno, Lewert ${ }^{160}$, Maszewo, Nieciszewo, folwarki Rudzianek i Siurpiszewo. Dokładny opis pól plebańskich z księgi parafialnej tu odpisany. Wsie parafialne:

${ }^{160}$ Lekcja niepewna. 
Serock, Łowinek, Maszewo, Jasieniec Zamkowy, Łowin, Nieciszewo, Brzeźno z dwoma młynami, Wioseczka, Jasieniec Stary, Glinki, Cierplewo Folwarczek, Wielonek Folwarczek, Rudzianek Folwarczek, Lubania Folwarczek, Lipiny Folwarczek oraz nowe kolonie (nie wymienione). Wiernych spowiadających się było około 500 osób, jedna rodzina żydowska oraz sporo luteran w poszczególnych wioskach, ale zboru własnego nie posiadali, tylko w jednym domu zbierali się na modlitwę. W Nieciszewie mieli własnego nauczycieli, uczącego ich dzieci. Było kilka osób nawróconych. Akuszerki były należycie poinstruowane. Organista Stanisław Radziński, ale dzieci nie uczył. Miał własne uposażenie 500 florenów monety pruskiej, zapisane przez Tuchotkę i inne jeszcze dochody. Przytułek był zniszczony, ale ubodzy mieszkali w starym domu plebańskim, mając wyżej wspomniane uposażenie 8 florenów, s. 798-801.

Zabudowania plebańskie przez aktualnego proboszcza wzniesione. Wykaz inwentarza, s. 801.

Odpis dokumentu króla Michała [Wiśniowieckiego], z 30 listopada 1670 r., dotyczący uposażenia dla parafii Serock, s. 802-805.

Odpis z zapisu uczynionego przez Remigiusza Aleksandra Powaltt Powalskiego z 1682r. oraz zapisu z 1691 r. Jana Franciszka Tuchotki, a także Franciszka Pawłowskiego, plebana serockiego z 18 maja 1711 r. Ponadto oświadczenie proboszczów serockich z 1711, 1714, 1715 i 1721 r. o odebraniu należnych zapisów. Aktualny proboszcz także skwitował odebranie powinności, s. 805-807.

Dekret reformacyjny, s. 808-812.

Ś w i e k a to w o. Wizytacja 11 czerwca 1746 r. Świątynia drewniana. Jej opis zewnętrzny. Prawo patronatu należało do kapituły włocławskiej. Nosiła wezwanie św. Marcina. Były przywileje odpustowe, ale nie było żadnego bractwa. Specjalnego uposażenia dla kościoła nie było, z wyjątkiem ofiar z pogrzebów, zapisu 200 florenów, dający roczny dochód 12 florenów na dobrach Łowin. Stan wnętrza świątyni i ołtarzy, s. 813-815.

Wykaz paramentów liturgicznych, s. 815-816.

Proboszcz Antoni Kiezlinkowski. Uposażenie jego składało się z czterech łanów ziemi oraz meszne z wsi: Świekatowo, Zalesie, folwark Lipnice, Błądzim, Ostrowite, Krupocino, Tuszyny, Łąkie Niemieckie i osada młyńska Łąkie, Szewno, nowa kolonia Reta, kolonie Szewo, Stążki i Kopytowo, Branica. Wiernych zobowiązanych do sakramentów wielkanocnych było około 300 osób, pewna, nie podana liczba luteran i Żydzi we wsi Szewo. Nawróconych było osób 15. Luteranie nie posiadali własnego zboru, jedynie dom modlitwy, zaś chowali się na polach, w rejonie swoich wsi. Akuszerki były pouczone. Był organista, ale dzieci nie uczył. Miał uposażenie, ale też i obowiązek śpiewania wraz z ludem różańca w niedziele i święta. Nie było przytułku, a jedynie domek przy cmentarzu, a ubodzy żyli z jałmużny, s. 816-818.

Opis zabudowań plebańskich oraz wykaz inwentarza, s. 818-819.

Odpis dokumentu zapisu 200 florenów na dobrach Łowin, dla parafii Świekatowo, s. 819-820.

Dekret reformacyjny, s. 820-823. 
L u b i e w o. Wizytacja 12 czerwca 1746 r. Świątynia drewniana, jej opis zewnętrzny. Prawo patronatu należało do arcybiskupów gnieźnieńskich, a nosiła wezwanie św. Mikołaja. Na jej uposażenie szły ofiary z pogrzebów, był też zapis 600 florenów na palenie światła. Ponadto należała pasieka, zdaje się że z 30 pniami, według przywileju królewskiego. Były przywileje odpustowe i bractwo św. Jana Nepomucena, zaprowadzone przez Augustyna Klińskiego, dziekana chełmińskiego i archidiakona pomorskiego diecezji kujawsko-pomorskiej ${ }^{161}$, ale bez własnego uposażenia. Opis wnętrza świątyni i ołtarzy, ss. 824-826.

Wykaz paramentów liturgicznych, s. 826-828.

Proboszcz Jan Łęgowski, posiadający na uposażenie cztery łany ziemi oraz pasieki wyżej wspomniane, a także dane ongiś przez biskupa Stanisława Szembe$\mathrm{ka}^{162}$. Meszne pobierano z wsi parafialnych: Lubiewo, Sucha, Klonowo, osady młyńskie Zamrza i Suchańskie. Parafian spowiadających się było 506, akatolików 3 rodziny, a mianowicie owczarza, pastora i dzierżawcy w Trutnowie, nie było natomiast Żydów. Nawróconych osób 7. Akuszerki pouczone. Organista Franciszek Sieradzki, uczący dzieci i mający swoje uposażenie. Przytułku nie było, a jedynie w domku należącym do proboszcza, z przyzwolenia poprzedniego proboszcza mieszkały dwie wdowy żyjące z jałmużny, s. 828-829.

Opis zabudowań plebańskich i inwentarz, s. 829-830.

Odpis dokumentu z 19 maja 1728 r., mocą którego ksiądz Jania Rulbiecki, aktualny proboszczz Lubiewa, zapisał 600 florenów dla kościoła w Lubiewie, z przeznaczeniem na światło i zabezpieczył to na synagodze w Sepólnie, s. 830.

Potwierdzenie króla Augusta II zapisu pasieki, dokonanego przez starostę jasienieckiego Franciszka Tuchotkę, na rzecz parafii w Lubiewie, wystawionego we Wschowie, dnia 20 marca 1719 r., s. 830-833.

Dekret reformacyjny, s. 833-836.

B y s $ł$ a w. Wizytacja 13 czerwca 1746 r. Świątynia solidnie zbudowana [murowana] i opis jej wyglądu zewnętrznego. Prawo patronatu należało do monarchy. Pierwszorzędnym wezwaniem była tajemnica Przemieniania Pańskiego, drugorzędnym zaś Wszyscy Święci. Były przywileje odpustowe oraz bractwa Najświętszego Imienia Jezus i Różańcowe, zaprowadzone przez dominikanów konwentu bydgoskiego. To bractwo posiadało własny fundusz 487 florenów, zapisany przez Agnieszkę Węsierską i zabezpieczony na dobrach wsi Wełpin, a odnośny dokument sporządzony w aktach grodu tucholskiego. Kościół parafialny nie posiadał specjalnego uposażenia, z wyjątkiem ofiar z racji pogrzebów. Opis stanu wewnętrznego kościoła i ołtarzy, s. 837-839.

Wykaz paramentów liturgicznych, s. 839-841.

Proboszcz Michał Poćwiardowski, mający do pomocy wikariusza Michała Hepner. Dochód proboszcza płynął z akcydensów oraz musznego z wsi Bysław, Minikowo, osad młyńskich Bysław, piła, Ruda i Zamku Tucholskiego, Wełpin i Bysławek oraz prawa wolnego połowu ryb, s. 841 .

\footnotetext{
${ }^{161}$ Biogram tego prałata zob.. C h o d y ń s k i, Katalog, s. 391-393.

${ }^{162}$ Był biskupem włocławskim w latach 1700-1706.
} 
Uposażenie kościoła [nie wiadomo, dlaczego tak to zanotowano, bo wydaje się, że chodzi o uposażenie proboszcza] składało się pięciu łanów i dodatków, łąk i ogrodów, a także jezioro zwane Popowek. Dokładny opis własności parafialnej. Parafian spowiadających się było 384, nie było Żydów. Akatolicy stosukowo nieliczni, bo we wsi Huta 4 rodziny, w Bysławiu 1, w Wełpinie 3 rodziny. Akuszerki wystarczająco pouczone. Organista Samuel Wroniecki, ale dzieci nie uczył. Miał mieszkanie i odpowiednie uposażenie. Przytułek nowowstawiony przez aktualnego proboszcza, w którym były dwie staruszki, żyjące z jałmużny. Był jeszcze maleńki domek, zapisany parafii, zdaje się przez niejakich Błaszków, na cele przytułku, s. 841-843.

Zabudowania plebańskie i inwentarz, s. 843-844.

Wykaz niektórych należności dla kościoła w Bysławiu i Cekcynie, zapisanych w wizytacjach, z 1692 r. testament Katarzyny Zębatki; z 1694 r. Eufrozyny z Płata Borowskiej, z 1772 zapis , z 1725 r., z 1740 r., z 1744 r., z 1745 r. i inne, tak na kościół bysławski, jak i na bractwo, s. 844-847.

C e k c y n. Wizytacja tego samego dnia, co w Bysławiu (13 czerwca 1746 r.). kościół w Cekcynie był filialnym kościoła w Bysławiu, drewniany, stary i wymagający naprawy. Opis zewnętrzny świątyni. Prawo patronatu należało do monarchy. Nosił wezwanie Świętego Krzyża. Uposażenia, poza opłatami z racji pogrzebów, specjalnego nie było. Nie było wiadomości o przywilejach odpustowych i bractwach. Opis wnętrza świątyni i ołtarzy847-848.

Wykaz paramentów liturgicznych, s. 848-849.

Uposażenie proboszcza składało się z pięciu łanów ziemi łąkami i ogrodami. Meszne pobierano z wsi Cekcin, Huminy, Zalesie, Zamarte, osada młyńska Okiersk i Nowy, a także kolonie Ostrowy, Krzywogonica, Kamionki, Zielonka. W pobliżu wsi Ostrowy znajdowało się jezioro nazywano Popówek, w którym był wolny połów ryb. Te dobra proboszczowskie były w dzierżawie Mikołaja Sulińskiego, płacącego najpierw 50 florenów, a ostatnio 60. Liczba wiernych spowiadających się wynosiła 277 osób, a także było trochę innowierców. Akuszerki zostały pouczone odpowiednio. Organista tu nie rezydował. Przytułku nie było. Plebania nowo wystawiona, inne budynki w ruinie. Inwentarza nie było. Do kościoła należały dwa ogrody, dające niewielki dochód, s. 846.

Dekret reformacyjny dla kościoła w Bysławiu i Cekcynie, s. 851-855.

\section{G61}

\section{A. OPIS KSIĘGI}

[1. Sygn. akt.] G61.

[2. Tytuł oryg.] Visitatio generalis ecclesiarum Archidiaconatus Pomeraniae tribus decanatibus, Gedanensi, Starogardiensi et Dirschaviensi distinctarum, per Perillustrem et Adm Rdum Dnum Bartholomeum Franciscum Xaverium Tro- 
chowski, Insignis Collegiatae Crusviciensis canonicum ${ }^{163}$, officialem Svecensem, praepositum Serocensen, ab Illustrissimo Excellentissimo et Reverendissimo Domino Domino Antonio Casimiro Ostrowski ${ }^{164}$, episcopo Vladislawiensem et Pomeraniae delegatum commissarium et deputatum visitatorem generalem in Anno Domini millesimo septingentesimo sexagesimo quinto expedita.

[3. Daty krańc.] 1765-1766.

[4. Opis zewn.] Łac.-Pol. $2^{0}(34,2 \times 21,0)$. Oprawa skórzana, z wytłoczeniami, dawna, w stanie więcej niż dobrym. Przy ponownej oprawie księgi niektóre numery stron częściowo zostały obcięte. Stron paginowanych 592. Stron niepaginowanych na początku księgi 4. Pismo czytelne, atrament wyraźny, czarny. Strony puste: 2 nlb., 4 nlb. karta po s. 320, 322, 44 nlb. po stronie102, karta nlb po s. 320, s. 322,590 .

Księga ta składa się właściwie z dwóch części. Część druga, to Visitatio Generalis Ecclesiarum Archidiaconatus Pomeraniae, Decanatuum Maevensis et Neoburgensi, per Perillustrem et Admodum Reverendum Dominum Bartholomeum Franciscum Xaverium Trochowski, Insignis Collegiatae Crusviciensis canonicum, Officialem Svecensem, Praepositum Serocensen, ab Domino Domino Antonio Casimiro Ostrowski, Episcopo Wladislaciensi et Pomeraniae, Delegatum Commissarium et Deputatum Visitatorem Generalem in Anno Domini Millesimo Septingentesimo Sexagesimo Sexto expedia. Ta druga część pierwotnie posiadała własną paginację od strony 1 do 267. Później sporządzono ołówkiem ciąg dalszy paginacji od s. 321 do 392 . Tę ciągłą paginację stosowano w niniejszym repertorium.

[5. Uwagi] Sporządzając paginację, karty puste pomijano, stąd przy opisie księgi musiano podawać formułę - po karcie.

Jest to czystopis, sporządzony później, jak to wskazują daty przeprowadzanych wizytacji, nie idące po kolei, ale sporządzony wkrótce po samej wizytacji, jeżeli na końcu księgi jest osobisty podpis wizytatora Trochowskiego.

W drugiej części wizytacji, począwszy od strony 329, na wstępie każdego protokółu, podawano położenie wsi parafialnej, jej przynależność administracyjna państwowo-kościelną, a także orientacyjną odległość od Gdańska.

Nazwy miejscowości podawano w oryginalnym, brzmieniu. Nie zawsze był tytuł proboszcza, często był to rektor, czy zarządca, dlatego podawano tak, jak było w tekście.

Jest sporo materiałów do życiorysów proboszczów.

Często podawano nie tylko specyfikacje odnoszącą się do ilości mieszkających nie tylko katolików, ale nawet innowierców. Ale nie było tak w każdym protokole.

Trudno jest nieraz rozróżnić, co było na uposażenie parafii, a co na uposażenie proboszcza. Nieraz wyraźnie zapisano, że np. kościół ma cztery łany ziemi i proboszcz też cztery łany ziemi. Nieraz nie było jasnego określenia. Często parafie

${ }^{163}$ Biogram tego kanonika, a także konfratra zakonu cysterskiego w Koronowie, zob. F i u t a k, Prałaci i kanonicy kruszwiccy, s. 116.

${ }^{164}$ Najpierw biskup inflancki, potem koadiutor i ordynariusz włocławski, w latach 1758(63)-1777, następnie arcybiskup gnieźnieński i prymas Polski. 
posiadały domy, w których mieszkali wieśniacy, płacący czynsz, a niekiedy też odrabiali przy żniwach. Zdarzało się, że podawano nawet nazwiska owych wieśniaków.

Nie notowano wiadomości o płonącej lampie przed Najświętszym Sakramentem, co było regułą, chyba, że paliła się ona jedynie przez określony czas.

Charakterystyczne dla tej wizytacji było zazwyczaj dokładne opisanie uposażenie organistów.

W drugiej części wizytator rozpoczynał protokół od podawania, do jakiego starostwa, województwa, często dekanatu, a nawet oficjałatu, dana parafia należała. Nie podawano tego w repertorium,

\section{B. ZAWARTOŚĆ KSIĘGI}

Tytuł Księgi, jak wyżej przytoczony, s. 1 nlb.

Uwaga, że w księdze tej są także protokoły wizytacji dekanaty gniewskiego i starogardzkiego, s, 3 nlb.

\section{[Dekanat gdański]}

G d a ń s k. Opis k a p li c y k ró 1 e w s k i e j, pw. Świętego Ducha, zbudowanej przez króla Jana III ${ }^{165}$, znajdujący się w pobliżu kościoła Najświętszej Marii Panny, który zagarnęli dla siebie akatolicy. Opis stanu zewnętrznego murowanej kaplicy, krytej dachówką, którą sprawił proboszcz gdański, prepozyt włocławski i kanonik płocki, Cyprian Wolicki ${ }^{166}$. Opis stanu wewnętrznego, w tym trzech ołtarzy, z których wielki zawierał figurę Chrystusa przyjmującego chrzest od św. Jana Chrzciciela. Sam ołtarz był wykonany artystycznie i znajdowało się w nim pozłacane tabernakulum. Ołtarz boczny po stronie prawej nosił wezwanie Matki Bożej i miał Obraz Maryi trzymającej Dziecię Jezus, zaś po stronie przeciwnej umieszczono ołtarz Bożej Opatrzności. Kaplica była wyposażona w potrzebne sprzęty, s. 1-2.

Spis inwentarza, argentariów i innych paramentów liturgicznych, s. 2-4.

Opis uposażenia kaplicy, składającego się głównie z ofiar, s. 4.

Opis uposażenia proboszcza, który posiadał dom niedaleko kaplicy, z czego pobierał czynsz. Był także dom, gdzie mieściła się szkoła dla chłopców i dziewcząt, na wyższej natomiast kondygnacji mieszkali trzej zakonnicy Jezuici, którzy odprawiali tu nabożeństwa. Jeszcze wyżej było mieszkanie dla proboszcza. Znajdowało się tam ponadto pomieszczenie, w którym dawniej, zanim wybudowano kaplicę, odprawiane były nabożeństwa, s 4-5.

W Gdańsku znajdował się konwent dominikanów, karmelitów i sióstr brygidek, na przedmieściu natomiast byli jezuici, konwent franciszkanów reformatów

${ }^{165}$ To król Jan III Sobieski, rządzący w Polsce w latach 1674-1696.

166 To późniejszy biskup sufragan pomorski. Biogram zob. C h o d y ń s k i, Katalog, s, 1005-1012; t e n ż e, Biskupi sufragani włoctawscy, s. 86-88. 
i bonifratrów, którzy wspomagali proboszcza w duszpasterstwie. Kościoły te były także uroczyście wizytowane. Sprawdzono stan ksiąg metryczny i innych, należycie prowadzonych, s. 5 .

Wizytacja miała miejsce 18 XI 1765 r., s. 5.

Ś w i ę t y W o j c i e c h. Wieś bpa włocławskiego z kościołem pod wezwaniem św. Wojciecha, od którego wieś ta wzięła nazwę. Parafia pozostawała pod zarządem księży misjonarzy św. Wincentego a Paulo. Którzy tu mieli swoje kolegium. Świątynia murowana, przed kilkoma laty odnowiona. Prawo patronatu należało do władz generalnych tego zgromadzenia. Opis świątyni, wewnątrz, której ołtarz wielki pod wezwaniem św. Wojciecha zawierał tabernakulum. Relikwii nie było, tylko cząstka Krzyża Świętego i św. Wojciecha, na co był autentyczny dokument wystawiony przez Konsystorz Gdański. Były przywileje odpustowe. Ołtarze boczne dwa, pod wezwaniem matki Bożej i św. Józefa. Opis wyposażenia zakrystii, ambony i organów czternastogłosowych, s. 6-7.

Spis naczyń liturgicznych, srebrnych i innych oraz wyposażenia świątyni w inne sprzęty, s. 7-10.

Wykaz anniwersarzy oraz sprawowanych tu nabożeństw, a także opis konfesjonałów i ławek, s. 10-11.

Metryki ochrzczonych, zaślubionych i zmarłych spisywano należycie, s. 11.

Stan zewnętrzny świątyni, fundamentów kamiennych. Sklepienie murowane w kaplicy św. Wincentego, gdzie zbierali się zakonnicy i w kaplicy św. Józefa, przeznaczonej dla wiernych. Dalszy opis stanu świątyni, z wieżą mieszcząca dzwony i zegar. Cmentarz ogrodzony, na którym chowano katolików, a także innowierców, z kostnicą. Na utrzymanie świątyni nie dawano ofiar, ponieważ wielu parafian sympatyzowało luteranizmowi, stąd wszelkie potrzeby załatwiano $\mathrm{z}$ akcydensu, s. 11-12.

Wsie parafialne: Święty Wojciech, Arciszewo, Będzieszyn, Borgfeldt, Czartowka, Agatowo, Janichowo, Maćkowy, Prędzieszyn, Rekin, Russoczyn Wielki, Russoczyn Mały, Schonfeldt, Straszyn, Świncz, Bojanowo, Czerwona Karczma, Borowa Karczma, Brzozowka Karczma, Ziabionka Karczma, Hudomin Karczma, Bartlin Owczarnia, Gołąbkowo Owczarnia, Boręty Folwark, Maćkowskie Grunty, Świnegłowy, inaczej Herberta. Wiernych zobowiązanych do spowiedzi wielkanocnej było 1435, jak to wynikało z ilości udzielonych komunii, ale do tego kościoła przychodzili wierni z najbliższych sąsiednich parafii, a nawet z Żuław, s. 12-13.

Dom dla rektora i zakonników wystawiony przez bpa Szaniawskiego. Mieszkał tu także organista. Opis zabudowań gospodarczych i uposażenia dla duchowieństwa oraz wykaz pobieranego mesznego i dziesięcin, a także wykaz legatów i innego uposażenia, s. 13-14.

Rocznie było 120 chrztów, 23 śluby i 65 pogrzebów. Dorosłych mężczyzn liczono 890, kobiet 900, chłopców 400, dziewcząt natomiast 450, s. 14.

Kaplica położona na górze, pod wezwaniem św. Wojciecha, gdzie odbywały się nabożeństwa $\mathrm{w}$ uroczystość patrona i w dni krzyżowe. Znajdowały się także w parafii trzy kościoły filialne, a mianowicie w Wojanowie, ale bardzo zniszczo- 
ny, w Juszkowie ${ }^{167}$, gdzie opanowali go od dłuższego czasu luteranie, i we wsi Ochra ${ }^{168}$, także opanowanej przez innowierców, s. 14-15.

Luteran znajdowało się około 1000 osób, a także kilku kalwinistów i memmonitów, s. 15.

Rektor kościoła Ignacy Kossendej, zakonnik. Wikariuszami byli także zakonnicy misjonarze, niepodanych imion. Jeden z nich był promotorem bractwa św. Józefa. Podobnie jak i nie podano nazwisk pozostałych zakonników, którzy głosili kazania. Organista Andrzej Lamprech, kantor Jan Fischer. Była szkoła, do której chodziły także dzieci innowierców. Akuszerki w parafii były należycie pouczone o sposobie udzielania sakramentu chrztu. Nie było nigdy szpitala, ale przed trzema laty zakonnicy zbudowali dom dla ubogich, s. 15-16.

Dekret reformacyjny, wystawiony 16 XI 11765 r., s. 16-17.

$\mathrm{O} 1 \mathrm{i}$ w a. Wieś opata cysterskiego. W tej wsi świątynia parafialna, murowana, pod wezwaniem św. Jakuba Większego, konsekrowana w 1604 r. przez sufragana włocławskiego Franciszka Łąckiego. Ponieważ z biegiem czasy uległa znacznej ruinie, została przez aktualnego rektora kościoła gruntownie odnowiona. Prawo patronatu należało do opata z Oliwy, s. 18.

Opis stanu wewnętrznego kościoła, z ołtarzem wielkim, gdzie znajdowało się tabernakulum i obraz przedstawiający Mękę i Zmartwychwstanie Pana Jezusa. Ołtarze boczne dwa, pod wezwaniem Zwiastowania Najświętszej Marii Panny i św. Jakuba, s. 18-19.

Spis inwentarza, tak argentariów, jak i innych utensyliów, szat, sprzętów kościelnych, obrazów, krzyży, konfesjonałów i ławek, s. 19-21.

Metryki wszystkie spisywano należycie, s. 21.

Opis wnętrza świątyni z chrzcielnica, amboną, chórem z organami nowymi i innymi instrumentami. Na portyku znajdował się obraz patrona, św. Jakuba. Dach, częściowo ogniotrwały z dachówki, a pozostała część ma być zrobiona. Wieża z sygnaturką, Dzwonnica od fundamentów odnowiona. Cmentarz ogrodzony. Uposażenie kościoła w zarządzie kolatora, s. 21-22.

Wsie parafialne: Oliwa, Nowy Szotland, Sopott, Strüsbrentau ${ }^{169}$, Zaspa, Wiedstok, Bronsen, Pletkau, Barowitz. Wiernych spowiadających się 1286, s. 22.

Nie było domu parafialnego, bo rektor i wikariusz mieszkali w klasztorze, Organista miał swój dom. Z kilku domów pobierano czynsz. Dochód z dziesięcin pobierany w ilości 400 florenów przez opata, a 100 florenów szło dla organisty. Rektor pobierał akcydens, s. 22.

Rocznie było ochrzczonych 98 osób. W parafii klasztor cysterski. Było wielu luteran, ale od 1758 r. nawróciło się 141 osób, s. 22.

Rektor kościoła Placyd Werner, przeor oliwski, świętej teologii i obojga praw doktor, od 1758 r. Akuszerki należycie pouczone. Szpital pod zarządem konwentu oliwskiego. Wikariuszem był zakonnik z Oliwy Oliweriusz Assmann, s. 22-23.

Dekret reformacyjny, wystawiony 21 XI 1765 r., s. 23.

${ }^{167}$ Nie wyliczono tej wsi poprzednio.

${ }^{168}$ Też nie wyliczono jej w wykazie wsi parafialnych.

${ }^{169}$ Pewnie dzisiejsze Brentowo. 
$\mathrm{M}$ a $\mathrm{t}$ a $\mathrm{r} \mathrm{n}$ i $\mathrm{a}^{170}$. Wieś opata oliwskiego. Świątynia bardzo stara, z kamienia i cegły, pod wezwaniem św. Walentego, prawa patronatu opata z Oliwy. W ołtarzu głównym św. Walentego znajdowało się tabernakulum. Dwa ołtarze boczne Matki Boskiej i św. Tymoteusza. Obraz św. Walentego uchodził za łaskami słynący. Były relikwie św. Walentego, Cyriaka, Marcina. Zakrystia za Wielkim ołtarze, s. 24.

Wykaz argentariów i pozostałego wyposażenia w paramenty liturgiczne i potrzebne sprzęty kościelne, s. 24-27.

Spisywano metryki ochrzczonych, zaślubionych i zmarłych, s. 27.

Opis stanu zewnętrznego kościoła, ś. 27

Wsie parafialne: Matarnia, Klukowo, Banin, Nerkowy, Byssowo, Smęgurzyn, Małe Kiełpino, czaple, Kokoszki, Ołpin. Parafianie zadowalająco korzystali z sakramentów ${ }^{171}$, s. 27.

Zabudowania dla proboszcza nowe i dobre, dla organisty zniszczone. Zabudowania gospodarcze wymagały naprawy. Opis uposażenia w postaci 6 łanów ziemi. Było prawo wolnego poboru drewna $\mathrm{z}$ lasów oliwskich. Jeden dom dawał dochód 15 florenów. Pozostałe dochody z ziemi, łąk, ogrodów oraz z musznego i akcydensów. Luteran około 30 osób, s. 27-28.

Zarządca parafii Kwintylianusz Ustarbowski, zakonnik cysterski z Oliwy. Organista Stanisław Adamowski. Dwaj zaprzysiężeni Witrykusi. Akuszerki należycie pouczone. . s. 28.

Wykaz pobieranego musznego z poszczególnych wsi, s. 28-29.

Dekret reformacyjny, wystawiony 22 XI 1765 r., s. 29-30.

$\mathrm{C}$ h w a s z c z y n. Wieś biskupa włocławskiego w dekanacie gdańskim. Świątynia wystawiona w pruski mur przez biskupa Antoniego Krzysztofa Szembeka ${ }^{172}$ w 1726 r., pod wezwaniem świętych Szymona i Judy Apostołów. Prawo patronatu należało do biskupa. Opis wnętrza świątyni z ołtarzem wielkim, w którym znajdowało się tabernakulum, z figurą Jezusa Ukrzyżowanego. Nie było relikwii, ani przywilejów odpustowych. Ołtarze boczne matki Bożej i Szymona i Judy. Zakrystia murowana, s. 31-32.

Spis inwentarza, argentariów i pozostałego sprzętu liturgicznego i innego, s. 32-33.

Opis sposobu sprawowania Służby Bożej. Nabożeństwa były w Chwaszczynie i w Kacku Wielkim, s. 33.

Stan wnętrza świątyni, z ławkami dobrymi, chórem z organem małym, czyli pozytywem. Księgi metryk sporządzano dobrze, s. 34.

Stan zewnętrzny świątyni. Dzwonnica z pruskiego muru z dwoma dzwonami i sygnaturką, s. 34 .

Wsie parafialne: Chwaszczyn, Ossowo i Tuchomie, s. 34.

Zabudowania dla proboszcza dobre z 1744 r. Organista mieszkał przy koście-

${ }^{170}$ Obecnie parafia Gdańsk-Matarnia.

${ }^{171}$ Nie podano tu żadnych szczegółów.

${ }^{172}$ Najpierw biskup inflancki, potem poznański, w latach 1720-1739 biskup włocławski, a w końcu arcybiskup gnieźnieński i prymas Polski. 
le w Kacku. Na uposażenie kościoła składały się cztery łany ziemi oraz łąki. Dochód zaś proboszcza składał się też czterech łanów, ogrodów, mesznego i akcydensu, s. 35 .

Rocznie było 30 chrztów i 12 ślubów, s. 35 .

Rektorem był Jan Witk Niepoczotowski, trzymający także probostwo w Kacku. Wikariuszem był Michał Witk Niepoczotowski ${ }^{173}$. Organista Franciszek Alman, mieszkający w Kacku. Witrykusami byli Franciszek Alman i Bartłomiej Dapk. Akuszerki były należycie poinstruowane, s. 35-36.

$\mathrm{K}$ a c k W i e $1 \mathrm{k}$ i. Wieś biskupa włocławskiego, z kościołem z pruskiego muru, z drewnianą wieżą z dwoma dzwonami i sygnaturką, pod wezwaniem św. Wawrzyńca, fundowanym przez biskupa [Felicjana Konstantego] Szaniawskiego $^{174}$, afiliowanym do parafii Chwaszczyno, s. 36.

Wykaz argentariów i innych paramentów liturgicznych oraz sprzętów kościelnych, s. 36-37.

Do sakramentów wielkanocnych, z parafii Kack i z parafii macierzystej [Chwaszczyno], było 456 osób. Na uposażenie kościoła były cztery łany ziemi, wydzierżawionej, z czego proboszcz otrzymywał czynsz, jak również z trzech wydzierżawianych domów, s. 37.

Wsie parafialne, z których pobierano meszne: Kack Wielki, folwark (może także Kack Wielki), Kack Mały z Redłowem, Kolibki, Leblewo (opanowane przez innowierców), Borowiec. We wsi Kolibki zbudowano ostatnio kaplicę. W parafii mieszkało 214 luteran i 9 kalwinistów. Innowiercy mieli swoje zbory w Radłowie ${ }^{175} \mathrm{i}$ w Leblewie. Witrykami byli Bartłomiej Dopk i Jakub Dopk, s. 37-38.

K o 1 i b k i, wieś Józefa Przebendowskiego, należąca do parafii Kack, gdzie tenże w roku 1764 zbudował kaplicę publiczną, murowaną, pod wezwaniem św. Józefa, z trzema ołtarzami. Najświętszy Sakrament przechowywano, ale światło paliło się jedynie podczas nabożeństw. Opis stanu wewnętrznego kaplicy z murowaną zakrystią, s. 38-39.

Wykaz naczyń liturgicznych srebrnych i pozostałych paramentów liturgicznych, licznych, jak na kaplicę. Zdaje się, że sprawowano tu sakramenty, bo znajdowała się chrzcielnica $z$ wodą i potrzebnymi do chrztu naczyniami. Opis nabożeństw. Wyposażenie kaplicy znaczne, z chórem i organami, wieżą z trzema dzwonami, cmentarzem należycie ogrodzonym, s. 39-41.

Nie było domu dla rektora Kocioła, ale w sąsiednim domu było pomieszczenie dla wygody przyjeżdżającego na nabożeństwa kapłana, ale mieszkał tam organista, który służąc tej kaplicy, miał osobne wynagrodzenie. Na wynagrodzenie dla odprawiającego kapłana był zapis 8000 florenów z rocznym procentem 5 od sta, zabezpieczony na grodzie $\mathrm{w}$ Skarszewach. $\mathrm{Z}$ tego zapisu rocznie proboszcz z Chwaszczyna pobierał 400 florenów rocznie. Na potrzeby kaplicy zbierano podczas nabożeństw jałmużnę, s. 42.

${ }^{173}$ Prawdopodobnie byli to bracia, albo krewni.

${ }^{174}$ Był biskupem kujawsko-pomorskim w latach 1706-1720, a następnie biskupem krakowskim. Biogram zob. N i t e c k i, Biskupi Kościoła w Polsce, k. 426.

${ }^{175}$ Raz pisano Redłowo, a raz Radłowo. 
Dekret reformacyjny dla wyżej wymienionych kościołów, spisany 23 XI 1765 r.

$\mathrm{L}$ a $\mathrm{n}$ g n o w o. Wieś opata oliwskiego. Świątynia murowana, fundowana przez Iwona Roleder, cystersa, w 1748 r, pod wezwaniem św. Mikołaja, nie konsekrowana, patronatu opata. Opis świątyni i jej stany wewnętrznego, a więc ołtarzy, tak wielkiego, jak i bocznych, w tym w kaplicy różańcowe oraz drugiej, zdaje się Chrystusa Ukrzyżowanego. Zakrystia znajdowała się za ołtarzem wielkim, s. 46-48.

Wykaz inwentarza naczyń liturgicznych, innych paramentów i pozostałych sprzętów kościelnych. Wykaz rzeźb. Były organy, s. 48-50.

Opis sprawowanych nabożeństw. W kościele znajdowały się trzy konfesjonały i stosowne ławki, Księgi metryk spisywano należycie, s. 50.

Stan zewnętrzny świątynia. Dzwonnica nowa stawiana w pruski mur. Ogrodzenie cmentarza murowane, wymagało naprawy. Na cmentarzu nowa kostnica, s. 50-51.

Na uposażenie kościoła szły czynsze z pięciu domów oraz akcydensy, s. 51.

Wsie parafialne: Langnowo, Skowarcz i Grabin. Spowiadających się było 540 osób, s. 51-52.

Opis zabudowań plebańskich, a więc plebanii dwukondygnacyjnej, na piętrze której mieszkał wikariusz, dom dla organisty i zabudowania gospodarcze. $\mathrm{Na}$ uposażenie były dwa łany ziemi oraz czynsze z domów, a także meszne4 z wsi Langnowo, Rozenberg, Skowarcz i Grabin. Fundator kościoła Iwo Roleder zapisał 1000 florenów na procent pięć od sta, na uposażenie bractwa różańcowego, które ma postarać się o odprawianie kaplicy różańcowej w każdą sobotę mszy za żywych i zmarłych, s. 52-53.

W ostatnim roku było 35 chrztów, 14 ślubów i 14 pogrzebów. Mężczyzn 269 osób, kobiet 277, chłopców 99 i dziewcząt 79, s, 53-54.

Dwie kaplice przy kościele, oratorium prywatne przy dworze z Grabinie. Luterani mieszkali w Greninie w ilości 63 osoby, i 2 kalwinistów, s. 54.

Zarządca parafii był zakonnik cysters Ernest Welski, posiadający także parafię Różyny, afiliowana do Langnowa. Organista Jozef Lipski, pobierający wynagrodzenie od mieszkańców wsi parafialnych. Była szkołą, gdzie uczyło się 4 chłopców i około 20 dziewcząt. Trzy akuszerki wystarczająco pouczone. Szpital nowy, wystawiony przez Rowedera ze specjalnym uposażeniem, s. 55.

R o z e m b e r g (Różyny), Wieś królewska z kościołem filialnym na stałe złączona z parafią Langnowo. Świątynia murowana, fundacji Iwona Roleder i Trembeckiej, dzierżawcy wsi Różyny, pod wezwaniem św. Wawrzyńca. Prawo patronatu, z przywileju króla Augusta, należało do opata oliwskiego. Opis wnętrza kościoła i jego ołtarzy. Był przywilej odpustowy na święto patrona św. Wawrzyńca oraz inne złączone z bractwem Boleści Najświętszej Marii Panny, Opis ołtarza wielkiego i ołtarzy bocznych. Zakrystia po prawej stronie ze skarbcem. Po lewej stronie ołtarza miejsce należycie zabezpieczone i ładne, gdzie przechowywano monstrancje z Najświętszym Sakramentem, s. 55-56,

Wykaz inwentarza, naczyń srebrnych, pozostałych paramentów liturgicznych 
i innych sprzętów kościelnych, trzy konfesjonały, chór ze starym organem. Metryki były prowadzone należycie, s. 56-58.

Opis stanu świątyni. Dzwonnica wystawiona w pruski mur., a na niej zegar, do którego konserwacji byli zobowiązani mieszkańcy. Cmentarz jeszcze nieogrodzony. Na cmentarzu, po obu stronach świątyni chowają się katolicy, natomiast akatolicy mają od dawna wyznaczone od dawna inne miejsce. Była kostnica, i w ni4ej było miejsce także na przechowywanie feretronów i innych rzeczy, należycie zamknięta, s. 58.

Uposażenie kościoła było z pobieranego akcydensu, s. 58.

Parafia składała się z jednej tylko wsi, Do spowiedzi wielkanocnej, razem z przybyszami z Żuław, było 216 osób. Ostatnie misje, przeprowadzone przez misjonarzy z parafii Święty Wojciech, były przed czterdziestoma laty s. 59.

Nie było zabudowań plebańskich, jedynie miejsce, gdzie dawniej się znajdowały. Nauczyciel miał mieszkanie i uczył dzieci, także luterskie. Pobierał wynagrodzenie od parafian, s. 59 .

Uposażenie kościoła stanowiły cztery łany ziemi, a także inne grunta i pewne należności pieniężne. Na uposażenie zaś proboszcza były także cztery łany, znajdujące się w dzierżawie. I roczny czynsz sumie 320 florenów, 59-60.

W ostatnim roku było 19 chrztów, 4 śluby i 6 pogrzebów. Ogółem mężczyzn naliczono 123 osoby, niewiast 120, chłopców 54, dziewcząt 42. Ponadto cztery rodziny luterskie, które miały razem 38 dzieci nauczyciel nazywał się Marcin Aleks, Witrykusi Gabriel Alex, sołtys z Różyn i Daniel Hus, katolicy, s. 60.

Dekret reformacyjny dla obydwóch parafii, wystawiony 15 XI 1765 r., s. 60-61.

Pr ę g o w o. Wieś z kościołem afiliowanym do Kaplicy Królewskiej w Gdańsku. Świątynia z kamienia, fundowana przez Krzyżaków, pod wezwaniem Bożego Ciała, patronatu królewskiego. Opis wnętrza świątyni z ołtarzem wielkim św. Tomasza z Akwinu, gdzie znajdowało się tabernakulum i z trzema ołtarzami bocznymi. Były odpusty. Zakrystia należycie wyposażona, s. 62 .

Wykaz inwentarza, naczyń srebrnych, innych paramentów liturgicznych, sprzętów kościelnych, obrazów i rzeźb. Niewielki organ, s. 62-64.

Bractwo Opatrzności Bożej, z uposażeniem fundowanym przez Ewę i Jana Trembeckich w roku 1763. Inwentarz własności bractwa, s. 64-65.

Opis nabożeństw w kościele, s. 65-66.

Metryki należycie spisywano, s. 66.

Opis stanu zewnętrznego świątyni, s. 66.

Do parafii należały wsie: Pręgowo Dolne, gdzie był kościół, Pręgowo Górne z młynem i papiernią, Bakowo, Goszyn, Bilkowko, Liszewo, Żuławka, Kleszczewo, Granicznawieś, Zaskoczyn, Domachowo, Buszkowy Dolne, Buszkowy Górne, Ostróżki, Czepielsk, Styngwałd, Rybiahuta, Dolny Rząbrzcz, Górny Ząbrzcz, Marszowy, Kolbudy, Nowa Kolonia inaczej Pustkowia, Studzionki, Nicponia, Cegielnia Małobielkowska, Wymysłowo, Folwark Żuławski, Chwiania, Olszanka, Cegielnia Zaskoczyńska, Wypych Buszkowski, Rębiska Buszkowskie, Banach, Majdany, Krymki i Wrzosy. Dawniej należała jeszcze wieś Warcz i Karczma 
Malencin. Na Wielkanoc spowiadało się 1155 osób. Misje były w 1765 r., przeprowadzone przez zakonników Misjonarzy [św. Wincentego], s. 66-67.

Dom dla proboszcza odbudowany przez aktualnego proboszcza. Organista miał też dom, dosyć dobry. Inne zabudowania. Uposażenie stanowiło 18 łanów, z czego większą część stanowiły lasy Wykaz pozostałego uposażenia i pobieranego mesznego, s. 68-69.

Rocznie ochrzczonych było 100 osób, ślubów 20, pogrzebów 50. Mężczyzn katolików i luteran 655, kobiet 805, s. 69.

We wsi Czepielsk była kaplica wystawiona w pruski mur, pod wezwaniem św. Mikołaja, należąca do Jezuitów z Gdańska, gdzie odprawiano w niedziele i święta. Opis kaplicy i jej wyposażenia. Było także oratorium przy dworze, z obrazem św. Mikołaja, który uważany był za łaskami słynący. Odprawiał ku kapłan z zakonu Jezuitów i z upoważnienia proboszcza pełnił opiekę duszpasterską, s. 69-70.

Prywatne kaplice znajdowały się: we wsi Bilkowko, należąca do dominikanów, w Ostróżkach, należąca do zakonników Bregidów, we wsi Domachowo, której \właścicielem był Prądzyński. Kaplice te były należycie utrzymane i wyposażone, s. 71.

Rektorem kościoła był Cyprian Wolicki, prepozyt włocławski, kanonii płocki i oficjał gdański. Nie rezydował tu, ale miał gorliwego wikariusza, Wincentego Schulca ${ }^{176}$. Organista i nauczycie, zarazem Franciszek Puzdrowski. Dwóch, niepodanego imienia, witrykusów. Dzieci uczyły się jedynie4 w okresie zimowym. Akuszerki należycie poinstruowane, s. 71.

Ż u $\nmid$ a w k a. Wieś Trembeckich, z kościołem afiliowanym do parafii Pręgowo, pod wezwaniem św. Małgorzaty, odnowionym w 1742 r, przez dziedziców. Opis świątyni i jej wnętrza. Zakrystia nowa, murowana z pruskiego muru, s. 71172.

Wykaz wyposażenie w naczynia liturgiczne i inne paramenta liturgiczne i sprzęty kościelne. Nie była zabudowań proboszczowskich. Uposażenie stanowiły cztery łany ziemi, znajdujące się w dzierżawie. Metryki spisywano w parafii, s. 72-73.

Dekret reformacyjny dla parafii Pręgowo, spisany 29 XI 1765 r., s. 73.

M i e r z e s z y n. Wieś królewska, w posiadaniu Trembeckiego, asesora ziemskiego tczewskiego. Dawniej była tu parafia, ale z braku wystarczającego uposażenia, afiliowana do parafii Pręgowo, ostatnio, przesz konsystorz gdański, dana w opiekę kapelanowi z Żuławki, Krzysztofowi Kozikowskiemu. Była to świątynia murowana, pod wezwaniem św. Bartłomieja. Opis świątyni i wyposażenia w paramenty liturgiczne. Zarządca tej świątyni był zobowiązany do odprawienia 3 mszy w ciągu roku 100 mszy za Jakuba Schultza, poprzedniego zarządcy. Był na to zapis, zabezpieczony na dobrach Barchanowy, należących do Czarnowskich, co zapisano w aktach miejskich starogardzkich w 1761 r. Do kościoła tego należała jeszcze wieś Pustkowie Mierzeszyńskie. Wiernych spowiadających się na

${ }^{176}$ To zapewne późniejszy oficjał, bardzo zasłużony. 
Wielkanoc było 81 0sób. Rocznie do chrztu było 15 dzieci, ślubów 2, pogrzebów 7. Luteran znajdowało się 181 osób. Uposażenie stanowiły cztery łany ziemi. Wykaz inwentarza gospodarskiego. Zarządca rezydował w we Wsi Żuławka. Organisty nie było, tylko nauczyciel. Dwóch, niepodanego imienia witrykusów. Akuszerki dwie, należycie poinstruowane, s. 74-76.

Dekret reformacyjny z dnia 29 XI 1765 r., s. 76-77.

$\operatorname{Przy}$ w i d z. Wieś z kościołem parafialnym, wystawionym w pruski mur, pod wezwaniem św. Franciszka Ksawerego, patronatu Ksawerego Trzcińskiego, kasztelanica dobrzyńskiego. Opis świątyni, jedynie z ołtarzem wielkim, gdzie znajdowało się tabernakulum. Były relikwie Świętego Krzyża. Zakrystia murowana, s. 78.

Wykaz inwentarza, a więc naczyń liturgicznych i innych paramentów kościelnych, s. 78-79.

Dzwonnica z pruskiego muru. Cmentarz jeszcze nie ogrodzony. Zmarłych jednak chowano na cmentarzu w środku wsi, na miejscu gdzie dawniej była świątynia, ale też był jedynie ogrodzony wysadzonymi drzewami, s. 79 .

Wsie parafialne: Przywidz, Klonowo Dolne, Klonowo Górne, Jakubska Huta, Michalska Huta, Polewo, Glasbarg, Szembek. Nie oddawano mesznego w snopkach, ale w pieniądzu, co dawało 200 florenów, pobieranych przez kolatora, który utrzymywał kapelana przy kościele. Na Wielkanoc spowiadało się 57 osób, bo inni byli luteranami. Był jedynie dom dla rektora, bez innych zabudowań plebańskich. Mały ogród, ale innych gruntów nie było, s. 79.

Nie było proboszcza, ani zarządcy, jedynie kolator utrzymywał kapelana Beniamina Bejer, zakonnika franciszkanina reformatę z konwentu Stolcemberg, ale bez wiedzy oficjała gdańskiego i bez jego aprobaty do sprawowania duszpasterstwa i sakramentów, s. 79-80.

Dekret reformacyjny, wystawiony 28 XI 1765 r., s. 80.

K $\nmid$ o d a w a. Wieś opata $\mathrm{z}$ Lądu, z kościołem parafialnym, murowanym z 1735 r., Z fundacji tegoż kolatora, pod wezwaniem św. Jakuba większego. Opis świątyni, jej stan wewnętrzny, ołtarze, a mianowicie wielkiego i trzech bocznych, chóru nowo postawionego z organem, zakrystii murowanej, położonej po stronie ewangelii, s. 811-82.

Wykaz inwentarza, naczyń srebrnych, innych paramentów liturgicznych i sprzętów kościelnych, bielizny i obrazów i mebli. Metryki spisywano. Dzwonnica złączona ze świątynią, wystawiona z pruskiego muru, cmentarz ogrodzony, $\mathrm{z}$ kostnicą, s. 82-85.

Wsie parafialne: Kłodawa, Zła Wieś, Żukcin, Hamer, Kleszczewo, Ulkowy, Łaguszewo, Zakrzewo, Kłobuczewo, Kacki, Trąbki Małe, Spowiadających się na Wielkanoc było 520 osób. Ostatnie misje, przeprowadzone przez reformatów, miały miejsce w 1764 r., s. 85.

Plebania w 1762 r. wystawiona staraniem obecnego proboszcza i kolatora. Organista też miał dom i był opłacany przez bractwo i kmieci. Inne zabudowania 
plebańskie. Proboszcz pobierał czynsz od tych, którzy mieszkali w domach należących do parafii, s. 85-86.

Wykaz pobieranego mesznego pobieranego przez proboszcza. Nie było żadnych zapisów, jedynie w 1744 r. Jakub Zaskoczyński zapisał dwa łany ziemi. Wykaz inwentarza gospodarskiego. Ponadto parafia posiadała jeszcze cztery łany. Dochód proboszcza też składał się z czterech łanów, ogrodów, mesznego i akcydensu, s. 86-87.

Rektorem kościoła był Adam Józef Mikołajewski, rezydujący stale, s. 87.

Od 1729 r. istniało bractwo szkaplerza, nie mające specjalnego majątku, ale posiadające własne paramenta liturgiczne, s. 87-88.

Organista Bartłomiej Kitowski, będący jednocześnie nauczycielem. Witrykusi Jakub Kędzierski z wsi Zawieś i Michał Sarnowski z Łaguszewa. Akuszerki były pouczone wystarczająco. Szpital był przy cmentarzu (we wsi zapewne), a w nim 3 podopiecznych, żyjących z jałmużny, bo specjalnego uposażenie nie było, s. 88.

Dekret reformacyjny z 3 XII 1765 r.

$\mathrm{K}$ i e $1 \mathrm{n}$ o. Wieś królewska w dekanacie gdańskim ze świątynia pod wezwaniem św. Wojciecha, murowana, patronatu królewskiego. Opis wnętrza z ołtarzem wielkim, gdzie znajdowało się tabernakulum, bocznymi ołtarzami i zakrystia murowana po stronie ewangelii, s. 90.

Wykaz inwentarza, a wiec naczyń srebrnych i innych paramentów liturgicznych i sprzętów kościelnych. Sposób sprawowania nabożeństw. Metryki spisywano. Cmentarz, z kostnicą, ogrodzony, s. 90-91.

Do utrzymania świątyni byli zobowiązani parafianie. Wsie parafialne: Kielno, Warzno, Warzenko, Małe Miszewo, Bojanie, Dobrzelin, karczemki, Wyczlin, Koleczkowo, Bieszkowice, Kielińska Huta, Warzeńska Huta, Kłosowo, Kłosówko, Kowalewo, Nowa Kolonia, Dąbrowa, Dębowa, Zielemsz, Głodowo, Wielkarola, Glinice, Pustkowie za Głodowem, Czernica Stara, Nowa Czernica, Piecowe, Piekiełko, Bieszk, Okuniewo, Lis, kamień, Psale, Łekno, Psalno, Konopiewo, Bożenka, Hamowane. Wiernych spowiadających się na Wielkanoc było 670 osób. Misje były w 1775 r., przeprowadzone przez reformatów, s. 92-93.

Opis zabudowań plebańskich, dosyć dobrych. Na uposażenie kościoła znajdowały się cztery łany oraz łąka, której użytkowanie było utrudnione z winy właściciela młyna. Las plebański był zdewastowany. Pobierano meszne. Wykaz inwentarza gospodarskiego, s. 93.

Uposażenie proboszcza było w ziemi, mesznem i akcydensie. W roku było 40 chrztów, 7 ślubów i 17 pogrzebów. Mężczyzn 340, kobiet 330, chłopców 90 i dziewcząt 100. Luteran 20 i kalwinistów 2, s. 93-94.

Rektor kościoła Michał Tczewski, nie rezydujący tu, lecz w Tokarach, majątku brata, a do parafii zjeżdżający na niedziele i święta. Wikariusz Michał Kitowski, s. 94.

Bractwo Szkaplerza z niewielkim wyposażeniem, s. 94.

Witrykusi Jakub Bieszk i Maciej Piątek. Akuszerki należycie poinstruowane, s. 94. 
S z y n w a ł d [Szemud]. Wieś królewska ze świątynią drewnianą, pod wezwaniem św. Mikołaja, patronatu królewskiego. Opis wnętrza świątyni, z ołtarzem wielkim, gdzie znajdowało się tabernakulum. Przy parafii istniało bractwo św. Barbary. Zakrystia po stronie ewangelii, s. 94-95.

Wykaz inwentarza, a więc naczyń srebrnych, innych paramentów liturgicznych i pozostałego sprzętu kościelnego. Chór muzyczny z pozytywem. Inwentarz własności bractwa św. Barbary, Sposób odprawiania nabożeństw. Dzwonnica drewniana. Cmentarz częściowo tylko ogrodzony, a na nim drewniana kostnica, s. 95-96.

Świątynia utrzymywana z ofiar parafian. Wsie parafialne: Szynwałd, Szynwaldzka Huta, Jeleńska Huta, Donimierz Mały, Donimierz Wielki, Głażyca, Grabowiec, Nowa Kolonia, Meruńska, Butkowska, Czarna Dąbrowa, Myglewskie, Rudowskie, Wuystok, Otalzyno. Wiernych spowiadających się na Wielkanoc było 350 osób. Nie było domu parafialnego dla proboszcza, czy organisty, chociaż było polecenie ordynariusza, aby parafianie wystawili te zabudowania. Na utrzymanie były cztery łany ziemi, ale aktualnie tylko z części płacono dzierżawę. W ostatnim roku było 10 chrztów, 5 małżeństw. Zmarłych nie podano. Mężczyzn naliczono 170 osób, kobiet 180, chłopców 90, dziewcząt 80. Luteran 20 osób. Na cmentarzu kaplica drewniana, niedawno wystawiona, pod wezwaniem św. Mikołaja, s. 96$-97$.

Organista Kazimierz Jasiński, Witrykusi Jan Szpech i Jan Rogalski, s. 97.

P r z o d k o w o. Wieś królewska z kościołem drewnianym, wymagającym naprawy, pod wezwaniem św. Andrzeja, afiliowanym do parafii Kielno. Prawo patronatu należało do króla. Opis świątyni. Światło przed najświętszym Sakramentem paliło się jedynie podczas nabożeństw. Ołtarz wielki i dwa boczne. Zakrystia po stronie ewangelii, s, 97-98.

Inwentarz naczyń srebrnych, innych paramentów liturgicznych i sprzętu kościelnego. Sposób sprawowania nabożeństw. Metryki spisywano dobrze. Opis zewnętrzny świątyni Dzwonnica z muru pruskiego. Kostnica drewniana. Na chorze organy, ale niezdatne do użytku, s. 99.

Na uposażenie parafii i proboszcza był akcydens Wsie parafialne: Przodkowo, Młynik, Smałdzino, Kobusewo, Dwie kolonie Grzybno i Krymka, Koszowo z dwiema koloniami Grzybno i Białymost, Załęże, Hopy, Szarlota, Gliniannagóra, Carna Huta, Boterfat, barwik, Pomieczyno Załęskie, Rą̧. Wiernych spowiadających się na Wielkanoc było 453 osoby. Zabudowania plebańskie bardzo stare i zniszczone, ale mieszkał w nich wikariusz. Nie było domu dla organisty, chociaż przed laty biskup Szembek wyznaczył miejsce, gdzie parafianie powinni taki dom wystawić. Inne zabudowania plebańskie także zniszczone. Kościół na uposażenie miał cztery łany ziemi, ale pozostawały one w dzierżawie. Była także łąka i las, ale ten został znacznie zniszczony przez właściciela wsi. Proboszcz ma pewien dochód z wydzierżawionej roli i łąk, z akcydensu i mesznego, s. 100.

W ostatnim roku było 28 chrztów, 7 ślubów i 8 pogrzebów. Parafian ogółem było 693 osoby, z czego 215 mężczyzn, 238 kobiet, 125 chłopców i 115 dziewcząt. Luteran mężczyzn było 23, kobiet16, chłopców 6 i dziewcząt 6, s. 100. 
Proboszcz Michał Kczewski z Kielna, zaś wikariusz mieszkający na miejscu Andrzej Lica. Witrykusi Stanisław Blaszk z Kobusewa i Bartłomiej Bejrowski ze wsi Tokary ${ }^{177}$. Akuszerki pouczone o udzielaniu w przypadku konieczności sakramentu chrztu, s. 100-101.

Dekret reformacyjny dla obydwóch parafii, wystawiony 26 XI 1765 r., s. 101-102 .

Uwaga, że w dekanacie gdańskim jest jeszcze parafia Żukowo, ale ta będzie zwizytowana przez samego biskupa, z okazji wizytacji tamtejszego klasztoru, s. 102.

\section{[Dekanat starogardzki]}

$\mathrm{S}$ t a r o g a r d. Miasto (civitas) królewskie z kościołem parafialnym, murowanym, fundowanym jeszcze przez Krzyżaków, pod wezwaniem św. Mateusza, Apostoła i Ewangelisty. Prawo patronatu należało do monarchy. Świątynia posiadała dwie kaplice, jedna Przemienienia Pańskiego, a druga św. Barbary. Opis wnętrza świątyni, z ołtarzem wielkim i dziewięcioma ołtarzami bocznymi, s. 103104.

Inwentarz naczyń srebrnych, paramentów liturgicznych i pozostałego sprzętu kościelnego, s. 104-106.

Utrzymanie kościoła z prawa i zwyczaju należało do mieszczan oraz były jeszcze inne źródła dochodów, s. 106-107.

Wsie należące do parafii: oprócz samego miasta, Sumin, Rękoczyn, Nowawieś, gdzie znajdował się kościół filialny, Kucborowo, Kolincz, Łowicz, Barchanowy, Jabłowo, gdzie znajdował się drugi kościół filialny, Koteze. Wiernych spowiadających się było 1234 osoby. Opis zabudowań plebańskich, s. 107.

Parafia miała na swoje utrzymanie kilka domów, skąd był czynsz oraz 4 łany ziemi koło Starogardu, cztery łany przy kościele św. Jana, który aktualnie znajdował się w ruinie oraz cztery łany przy kościele filialnym w Jabłowie, a także cztery łany przy kościele w Nowejwsi. Do tego łąki i odgrody. Ponadto prawo propinacji i dochody z karczmy na przedmieściu oraz czynsze z domów. Także dochód z mesznego wsi, tu dokładnie wyliczony. Wykaz inwentarza gospodarskiego, s. $107-108$.

W ostatnim roku było 77 chrztów, 18 ślubów i 26 pogrzebów.

Katolików obojga płci było 1234 osoby, z czego mężczyzn 600, a kobiet 634, s, 108 .

Oratoria (kaplice) prywatne dwa, we wsi Sumin we dworze, na piętrze, gdzie mogli korzystać z nabożeństw wszyscy na mocy zezwolenia władzy duchownej i we wsi Łowicz. Innowiercy mieli zwój zbór w mieście. Luteran w parafii naliczono 1278 mężczyzn i 313 kobiet. Żydzi w znacznej liczbie mieszkali we wsi Klincz, s. 108-109.

Rektor kościoła Jan Bastkowski, ale nie rezydował, wikariusz J. Gręca ${ }^{178}$ i jesz-

${ }^{177}$ W wykazie wsi parafialnych Trokar nie było,

${ }^{178}$ Nie podano pełnego imienia. 
cze jeden kapłan Anzelm Łopaczewski, dominikanin, będący promotorem bractwa różańcowego, które posiadało w kościele swój ołtarz własny Matki Bożej, z obrazem przyozdobionym szlachetnymi kamieniami i innymi wotami, tu częściowo wymienionymi. Spisy inwentarza bractwa różańcowego. Było to spisane w księdze tegoż bractwa, s. 109-110.

Organista, niepodanego imienia, wynagradzany ze skarbony kościoła i przez miasto. On też uczył chętnych. Witrykusi, niepodanego nazwiska, dwóch katolików i dwóch akatolików. Cztery akuszerki potrafiące chrzcić. Szpital przy bramie nowomiejskiej, ale za miastem, znacznie zniszczony, z 10 podopiecznymi, którzy otrzymywali utrzymanie, s. 110.

$\mathrm{N}$ o w a W i e ś. Kościół drewniany pod wezwaniem św. Anny, prawie całkowicie zniszczony, z ołtarzem wielkim i dwoma bocznymi, afiliowany do parafii w Starogardzie. Wykaz inwentarza, s. 111.

J a b ło w o. Kościół murowany, jak podają, fundowany przez Krzyżaków, pod wezwaniem św. Wawrzyńca, przez siedemdziesięcioma laty afiliowany do parafii w Starogardzie. Opis wnętrza świątyni. Nie przechowywano tu Najświętszego Sakramentu. Ołtarz wielki i dwa boczne. Dzwonnica (pewnie wieża), której część powyżej murów kościoła była drewniana, ale zniszczona. Ziemia do kościoła należąca w ilości czterech łanów dzierżawiona przez luteranina Packiego. Wykaz inwentarza tej świątyni, s. 11-113.

Dekret reformacyjny dla tych kościołów, wystawiony31 X 1765 r.

C z e r s k. Wieś królewska z kościołem drewnianym nowym, wystawionym po spaleniu się w 1756 r. starego, pod wezwaniem Marii Magdaleny, przez dzierżawcę Lukowicza, z udziałem innych dobroczyńców, a mianowicie Klińskiego, Franciszka Orlikowskiego, Mikołaja Lewald i Franciszka Kowalewskiego, a także aktualnego proboszcza, prawa patronatu królewskiego. Opis wnętrza świątyni, z ołtarzem wielkim i czterema bocznymi. Lampa przed najświętszym sakramentem nie paliła się, bo nie było na to uposażenia. Zakrystia po stronie ewangelii. Chór muzyczny z nowym pozytywem, s. 116-117.

Wykaz inwentarza i paramentów liturgicznych, s. 117-118.

Sposób sprawowania nabożeństw, s. 118.

Opis zewnętrznego stanu świątyni. Na jej utrzymanie były ofiary parafian i akcydens. Wsie parafialne: Czersk, Nieżorawa, Mokre, Malechin, Lutam, Zapendowo, Retel, Legmont, folwarki, czyli pustkowia, Uboga, Ostrowy, Konigort, Kłodnia, Sienica, Twarożnica, Łosiny, Partki, Kurcze, Ostrowite, Juncza, Kamionka, Cys, Łubna, Kwieki, Sloska. Wiernych spowiadających się na Wielkanoc 500 osób. Ostatnie misje w 1746 r., s. 118-119.

Zabudowania plebańskie w złym stanie, ale było mieszkanie dla proboszcza i nderiusza. Organista sam wybudował dobie dom na placu mu wskazanym. Inne budynki gospodarcze. Na uposażenie miał kościół 5 łanów ziemi wg przywileju otrzymanego jeszcze od Krzyżaków w 1382 r., który to dokument wyciągnięto w 1612 r. z akt grodzkich tucholskich i znajdował się w aktach wójtowskich czer- 
skich. Aktualnie jednak było tylko 4 łany i łąki. Były też inne zapisy poczynione przez Stanisława Krużewskiego i Józefa ndeneikiego. Inwentarz gospodarski i wykaz pobieranego mesznego, s. 119-'21.

W ostatnim roku ochrzczono 80 dzieci, zaślubiono 22 pary i 18 osób pochowano. W dobrach Mokre znajdowała się kaplica przy dworze, ale stojąca osobno, pięknie urządzona, gdzie odprawiano nabożeństwa na mocy indultu papieskiego. Luteran było 24 osoby, s. 121.

Rektorem kościoła był Szymon Plutowski, zatrudniający wikariusza, Franciszka Ksawerego Czarnowskiego, dominikanina z Gdańska, będącego promotorem bractwa. Organista Franciszek Pałudzki. Witrykusami byli Wojciech Sabinowski, sołtys z Czerska, Błażej Sopowski kowal oraz Mateusz Szopowski ${ }^{179}$ i Stanisław Górna. Akuszerki dwie, wystarczająco pouczone, s. 121-122.

Ł ą g. Wieś królewska, z kościołem afiliowanym do parafii w Czersku, chociaż nie podano, czy drewnianym, czy murowanym ${ }^{180}$, znajdującym się $\mathrm{w}$ stanie dużego zniszczenia i wymagający naprawy, pod wezwaniem Nawiedzenia Najświętszej Marii Panny ${ }^{181}$. Prawo patronatu należało do monarchy. Opis wnętrza świątyni, trzech ołtarzy. Zakrystia drewniana, zniszczona, s. 122.

Wykaz inwentarza i paramentów liturgicznych. Nabożeństwa, w co trzecią niedzielę Opis stany zewnętrznego świątyni. Wsie należące do parafii: Łąg, Prusy, Będźmierowice, młyn Zawada, Zimne Zdroje, karczma Złemięso, Tleniny, Klaskawa, Przyjaźnia, Gotelb, Klonówka, Budzisk, Jastrzębie, Kamienna Góra, Bielawy, Mosna. Wiernych spowiadających się 400 osób. Ostatnie misje w 1750 r., s. 122-124.

Opis zabudowań plebańskich. Uposażenie kościoła z czterech łanów i łąk. Uposażenie proboszcza z czterech łanów ziemi, które dzierżawił za 100 florenów. Organista ten sam, co w parafii Czersk, ale ty pobierał wynagrodzenie, dosyć dokładnie przedstawione, s. 124.

Dekret reformacyjny dla obydwóch parafii, wystawiony dnia 17 X 1765 r.

$\mathrm{K}$ i s $\mathrm{z}$ e w a $\mathrm{S} \mathrm{t}$ a $\mathrm{r} \mathrm{a}^{182}$. Wieś królewska $\mathrm{z}$ kościołem drewnianym w roku 1741, kosztem Stanisława i Katarzyny z Iwanickich Skórzewskich, starostów kiszewskich i pracą parafian, zbudowanym na cześć św. Marcina, a jego patronem był św. Walenty, konsekrowanym, za zezwoleniem biskupa włocławskiego [Antoniego] Dembowskiego, przez sufragana chełmińskiego biskupa Fabiana Franciszka Pląskowskiego w 1759 r. W tym samym dniu został przezeń konsekrowany ołtarzwielki,gdzieumieszczonorelikwieświętychmęczenników InnocentegoiKlemensa. Prawo patronatu należało do króla. Opis ołtarzy. Zakrystia drewniana, s. 128-129.

Wykaz inwentarza, paramentów liturgicznych i innych sprzętów kościelnych. Księgi metryk spisywano prawidłowo. Opis zewnętrznego stanu świątyni i jej

\footnotetext{
${ }^{179}$ Te dwa nazwiska podobne, ale tak zapisane,

${ }^{180}$ Pewnie drewnianym, bo zakrystia była drewniana.

${ }^{181}$ Obecnie jest wezwanie Narodzenia Najświętszej Marii Panny.

${ }^{182}$ Teraz pisze się Stara Kiszewa.
} 
wyposażenia. Dzwonnica wystawiona w pruski mur. Na ogrodzonym cmentarzu, w miejscu gdzie stała dawniej świątynia, wystawiono kaplicę drewnianą pod wezwaniem św. Barbary, s. 129-132.

Wsie parafialne: Stara Kiszewa, Zamkowa Kiszewa, czyli Zamek, Nowa Kiszewa, Bartoszówlas, Komarzyny, Olpuch, Bartel, Studziennice, Huta, Maliki Górne, Strzellis, Pałubin, Bożepole, Chwarzno, Chwarzcienek, Foshuta, Szuflarce, Bukowiec Stary, Bukowiec Nowy, Folwark Bukowiecki, Pustkowie Bukowieckie, Ruda, Cięgardło, Barłogi, Tyszarstwo, Gołub, Wygonin, Nierybno, Struga, Żubrek młyn, Cieciórka, Szpechta, czyli Krowia Góra, Kamionna, czyli Siniki, Uroza, Kozia, posiadłość ziemska zwana Żurowo bez mieszkańców, a także takaż posiadłość zwana Babie. $Z$ tych wsi do sakramentów wielkanocnych zobowiązanych było przystępować około 800 osób. Opis zabudowań dla proboszcza i wikarego i także gospodarczych. Na uposażenie były cztery łany ziemi oraz łąki, a także domy, z których był należny czynsz. Wykaz inwentarza w gospodarstwie, s. 132-134.

Wykaz pobieranego mesznego z poszczególnych wsi, s. 135-136.

W ostatnim roku były 84 chrzty, 20 śluby oraz 50 pogrzebów. Ogółem mężczyzn naliczono 360, kobiet 384, chłopców 160, dziewcząt 181. Dorosłych luteran obojga płci było na terenie parafii 680 , zaś dzieci 310 . Żydzi mieszkami we wsi Chwarzcinek w liczbie około 45 osób, dając pewne opłaty z racji postawienia dużego domu i synagogi, a także za miejsce dla pochówków. Akatolicy posiadali we wsi Nowa Kiszewa swój zbór, ale ten praktycznie uległ zniszczeniu, tak, iż było tylko miejsce z prowizoryczną dzwonnicą. Była też tam szkoła luterańska. Mieli też zezwolenie od właścicieli wsi Bartoszówlas i Nowy Bukowiec na urządzenie cmentarzy, s. 136-137.

Rektor kościoła Andrzej Schulz i wikariusz Jakub Niedrzwicki. Ostatnie misje w 1752 r. Organista Marcin Bławat, opłacany ze skarbony oraz miał on pewne grunta i prawo do opłat od mieszkańców. Czterech zaprzysiężonych witrykusów. Akuszerki wystarczająco poinstruowane.

P o l a s z k i S t a r e. Wieś z kościołem od niepamiętnych czasów afiliowanym do parafii w Kiszewie, pod wezwaniem św. Mikołaja. W roku 1752, na miejscu gdzie stała stara świątynia, wystawiono ładną i murowaną, kosztem Stanisława i Katarzyny z Iwańskich, Skórzewskich, którą konsekrował w 1758 r, biskup sufragan chełmiński Fabian Franciszek Pląskowski. Prawo patronatu należało do króla. Opis czterech ołtarzy i całego wnętrza świątyni. Dzwonnica murowana. Cmentarz ogrodzony, s. 138-139.

Wykaz inwentarza i naczyń srebrnych oraz pozostałych sprzętów liturgicznych i kościelnych, s. 139-142.

Na uposażenie składały się cztery łany ziemi, dane jeszcze w 1420 r., wyjęte z dóbr Polaszki. Pomieszczono tu odpis dokumentu z tegoż roku o powyższej darowiźnie. Aktualnie w użytkowaniu znajdował się jedynie jeden łan, s. 142-144 .

Wsie parafialne: Polaszki Stare, Polaszki Nowe, folwark Wilczebłoto. We wsi Polaszki Nowe znajdował się zbór protestancki luterański. Proboszcz posiadał 
jeszcze ogrody oraz czynsz płacony z wyżej wspomnianego łanu. We dworze znajdowała się kaplica, gdzie za zezwoleniem Konsystorza Gdańskiego odprawiał msze jezuita Konstanty Wysocki. W ciągu roku ochrzczono około 10 dzieci. Katolików dorosłych obojga płci było około 100 osób. Akatolików także tylu było, z tym, iż we wsi Polaszki Nowe byli sami innowiercy, s. 144-148.

Dekret reformacyjny dla obydwóch kościołów, wystawiony22 października 1765 r., s. 146-152.

P o g u t k o w y. Wieś opata z Pelplina. Kościół parafialny, murowany, pod wezwaniem Apostołów Piotra i Pawła, fundowany w 1715 r. przez Tomasza Franciszka Czapskiego, ale nie konsekrowany, jedynie poświęcony. Prawo patronatu należało do opata z Pelplina. Opis wnętrza świątyni i sześciu ołtarzy. Przy niej było bractwo Aniołów Stróżów, zaprowadzone w 1637 r. zakrystia murowana, s. 152 ,

Wykaz paramentów liturgicznych i pozostałych sprzętów kościelnych. Metryki ochrzczonych, zaślubionych i zmarłych spisywano należycie. Opis stanu zewnętrznego świątyni Dzwonnica i kostnica murowane. Cmentarz ogrodzony, s. $152-155$.

Uposażenie składało się z dwóch łanów ziemi, znajdujących się w dzierżawie oraz z mesznego pobieranego z wsi i kolonii, których było 21. A wiec: Kleszczewo, Jaroszewy, Kożmin, Czernikowy, Więckowy, Głodowo, Jądrowy, Maliskowy, Wałdówko, Deka, Bora, Lisewko, Tomaszewko, Brzęczek, Lipia Góra, Zawada, Bukowiec, Milonki, Szczepanowo, Pogutkowy, Kobyle. Zobowiązanych do sakramentów wielkanocnych było 960 osób. Opis zabudowań plebańskich i ogrodów, s. 155-156.

Nas uposażenie były oprócz dwóch łanów ziemi, jeszcze cztery we wsi Kleszczewo i cztery w Kozminie, ale te z powodu większej odległości były w dzierżawie. Specjalnych zapisów nie było, z wyjątkiem małego domku ofiarowanego przez nieżyjącego opata pelplińskiego Hieronima Turno, z którego czynsz był przeznaczony na lampę [zapewne przed Najświętszym Sakramentem. Inwentarza gospodarskiego nie było, s. 156-157.

W ostatnim roku było 79 chrztów, 14 ślubów i 38 pogrzebów. Parafia liczyła469 mężczyzn, 492 kobiety, chłopców 253 i dziewcząt 265. Luteran w całej parafii naliczono 230 . Na terenie parafii znajdowały się dwa oratoria prywatne, a mianowicie we dworze w Kogutkowych dla wygody opata tam rezydującego i w folwarku Malari, także do klasztory należącego. Rektorem kościoła był Anzelm Powalski, zakonnik cysters z Pelplina, zawsze tu rezydujący. Akuszerki należycie pouczone. Dwaj Witrykusi, Antoni Milentz i Jan Ossowski. Kilkoro uczniów uczy organista Andrzej Myszkier, s. 157-158.

Dekret reformacyjny z dnia 14 października 1765 r., s. 158-159.

P i n c z y n. Wieś królewska z kościołem parafialnym, drewnianym, wystawionym w 1742 r. staraniem parafian i różnych darczyńców, w szczególności Stanisława i Katarzyny Skórzewskich, pod wezwaniem św. Elżbiety. Przez aktualnego proboszcza w 1759 r. świątynia została ładnie przyozdobiona i tegoż roku konsekrowana przez biskupa Fabiana Franciszka Pląskowskiego. Prawo patronatu 
należało do króla. Opis wnętrza świątyni, ołtarzy, gdzie znajdowało się tabernakulum, przed którym światło paliło się jedynie podczas nabożeństw. Było bractwo św. Józefa z przywilejem odpustowym. Cztery ołtarze boczne. Zakrystia drewniana po stronie ewangelii, s. 160-161.

Spis inwentarza, a więc naczyń liturgicznych srebrnych, pozostałych paramentów liturgicznych i sprzętów kościelnych. Sposób sprawowania nabożeństw. Księgi metryk spisywano. Stan zewnętrzny świątyni. Dzwonnica z pruskiego muru. Cmentarz ogrodzony, a na nim kostnica, s. 161-163.

Utrzymanie kościoła, naprawy, odbudowa, także i zabudowań plebańskich, należy z dawnego zwyczaju pruskiego do parafian. Do parafii należały wsie: Pinczyn z dwiema koloniami Pinczynem i Przemyśle, nowa kolonia zwana Nowy Dworzec, salin z nowa kolonia Sadlinek, Piściennica z nowa kolonia Bukowiec, Secemin z kolonia Secyminek, folwark Pałubinek. Spowiadających się na Wielkanoc parafia liczyła 323 osoby. Opis zabudowań proboszcza i organisty. Na uposażenie były cztery łany ziemi, ale ta notorycznie byłą umniejszana i dlatego należy dokonać należytego pomiaru. Były także łąki. Spis inwentarza gospodarczego, s. 163-165.

Proboszcz pobierał meszne pobierano z wsi parafialnych, tu dokładnie wyliczone, a także akcydens. W ostatnim roku było 38 chrztów, 11 ślubów i 13 pogrzebów. Mężczyzn w parafii naliczono 142 osoby, kobiet 181, chłopców 54 i dziewcząt 69. Luteran, dorosłych i dzieci ogółem 269 osób, s. 165.

Rektor kościoła Tomasz Józef Lyszkowski. Organista, którego nazwiska nie podano, był i miał określone uposażenie. Akuszerki należycie pouczone. Wspomniano także o trzech kobietach usługujących kościołowi, ale bezdomnych [zapewne mieszkają przy kościele], s. 165-166.

Dekret reformacyjny z dnia 25 października 1765 r., s. 166-168.

Z b 1 e w o. Świątynia wystawiona w pruski mur, w roku 1720, jak mówią zapisy, pod wezwaniem św. Michała Archanioła. Opis ołtarza wielkiego z tabernakulum i trzech ołtarzy bocznych. Zakrystia murowana, s. 169.

Inwentarz naczyń srebrnych i pozostałych paramentów liturgicznych i sprzętów kościelnych. Opis stanu zewnętrznego kościoła. Cmentarz ogrodzony. Dzwonnica złączona z kościołem. Kostnica drewniana, s. 169-172.

Wsie parafialne: Zblewo, Iwiczno, Borzechowo ${ }^{183}$, Nierasowo, Radziejewo, Bląweld. Ponadto nowe kolonie, zwane wsiami, jak Krzewina, młyn zwany Młyńsk, młyn Czubek, Jwickie Piece, Czarne, Libiki, Łążek, Trzechowo, Kaliska, Cis, Lipe, Kazub, Dunajek, Zamrze, Lipska, Piła, Lipska Karczma, Białachówko, Nieradowskie Piekiełko, Nieradowko, Białachowko Radziejowskie. Wiernych do spowiedzi wielkanocnej było 700 osób. Misje ostatnie w 1741 r, przeprowadzone przez księży Misjonarzy. Opis zabudowań plebańskich i organisty oraz zabudowań gospodarczych. Wykaz ogrodów. Na uposażenie były cztery łany ziemi. Była na to dokument z $1340 \mathrm{o} 0$ r., zapisany ostatnio w księgach grodu w Skarszewach. Proboszcz miał prawo wolnego wyręby drewna w lasach starostwa. Spis inwenta-

${ }^{183}$ Siedziba starostwa niegrodowego. 
rza gospodarczego. Ponadto proboszcz pobierał meszne, tu dokładnie wyliczone i akcydens, s. 172-174.

W ostatnim roku chrztów było 53, ślubów 20 i pogrzebów 35. Mężczyzn parafia liczyła 189 osób, kobiet 234, chłopców 23, dziewcząt 30 ${ }^{184}$. We wsi Kazub było 7 Żydów, zaś luteran ogółem w parafii naliczono 300 osób, s. 174.

Rektor kościoła Józef Wenda, który posiada jeszcze parafie w Lubichowie, ale na miejscu rezyduje. Wikariusz Piotr Piątkowski. Organista Gabriel Telchner. Ponadto byli trzej Witrykusi, niewymienieni z nazwiska oraz akuszerki wystarczająco pouczone, s. 174-175.

L u b i c h o w o. Wieś z kościołem afiliowanym do parafii Zblewo. Świątynia drewniana, pod wezwaniem św. Jakuba Większego i św. Barbary, zbudowana w 1740 r., z funduszy kościelnych, z pomocą niektórych ofiarodawców, szczególnie Kazimierza Zawadzkiego, asesora tucholskiego, aktualnego dzierżawcy starostwa borzechowskiego. Prawo patronatu należało do króla. Opis trzech ołtarzy. Zakrystia drewniana, s. 175.

Inwentarz naczyń srebrnych i innych paramentów liturgicznych i sprzętów kościelnych. Księgi metryk spisywano. Opis stanu zewnętrznego kościoła. Dzwonnica nowa, drewniana i wolnostojąca. Cmentarz ogrodzony. Kostnica. Na utrzymanie świątyni były składki z parafii, s. 175-176.

Wsie parafialne: Lubichowo, Ossowo, Zielona Góra, Bietowo, Steklno, nowe kolonie Mościska, Budy Zielonogórskie, karczma zwana Nicponia, Miały, osada młyńska zwana Berent, czyli Młynki, karczma zwana Pazna, czyli Mort, Karczma zwana Szyszkowie, czyli Potun, Wilcze Błota, czyli Huta Lubichowska, Krempka, czyli Huta Nowa, karczma zwana Kaliska. Wiernych spowiadających nie było 400 osób. Opis zabudowań plebańskich i ogrodów. Na uposażenie były cztery łany ziemi. Przytoczono tu daty dokumentów mówiących o tym uposażeniu, jak i o prawie pobierania mesznego, także dokładnie określonego, s. 176-178.

W ostatnim roku było 28 chrztów, ślubów 6 i pogrzebów 40. Parafia liczyła 121 mężczyzn, 134 kobiety, 23 chłopców i 16 dziewcząt. Luteran mieszkało około 200 osób. Byli dwaj Witrykusi zaprzysiężeni, Michał Trzosowski i Paweł Radomski. Dawniej był tu przytułek, ale pozostał po nim plac, początkowo wydzierżawiany, co dawało parafii pewien dochód, ale z biegiem czasu poszło to w zapomnienie i użytkowali go mieszkańcy wsi, s. 178.

Dekret reformacyjny dla obydwóch parafii, wystawiony 28 listopada 1765 r., s. $178-179$.

B o b o w o. Wieś królewska z kościołem parafialnym, murowanym, pod wezwaniem św. Wojciecha, jak mówią dawne zapisy, konsekrowanym. Prawo patronatu należało do monarchy. W ołtarzu głównym znajdowało się tabernakulum, ale lampa przed nim nie zawsze się paliła. Dwa ołtarze boczne. Zakrystia po stronie ewangelii, murowana, s. 180.

${ }^{184}$ Trudno powiedzieć, dlaczego było tak mało dzieci. Może jakaś zaraza czy choroba to sprawiła? 
Spis naczyń srebrnych, innych paramentów liturgicznych i pozostałych sprzętów kościelnych. Metryki spisywano. Opis zewnętrznego stanu świątyni. Dzwonnica, przyległa do świątyni, z pruskiego muru, znacznie zniszczona. Cmentarz ogrodzony. Kostnica drewniana, s. 180-182.

Utrzymanie świątyni pochodziło z ofiar parafian oraz z jednego łana ziemi, co dawało roczny czynsz oraz z sześciu domów, także dających dochód roczny. Wsie parafialne: Bobowo, Wysoka z folwarkami Smoląg i Żabienki. Spowiadających się, wraz z filialną parafią Dąbrówka było 400 osób. Opis zabudowań plebańskich. Proboszcz miał cztery łany ziemi i prawo wyrębu drewna. Wykaz pobieranego mesznego. Spis inwentarza gospodarczego. Proboszcz miał także w użytkowaniu dodatkowe cztery łany z parafii Dąbrówka, s. 182-184.

W ostatnim roku było 20 chrztów, 16 ślubów i 14 pogrzebów. Parafia liczyła 238 mężczyzn, 168 kobiet, 14 chłopców i 6 dziewcząt ${ }^{185}$. Luteran było 14, s. 184.

Rektorem kościoła był Jan Fankidy, posiadający także parafie Dąbrówka i przy niej rezydujący. Wikariusz Piotr Piątkowski, który za zgodą proboszcza i z zezwolenia Oficjała, służy kościołowi w Zblewie. Organista nie miał specjalnego uposażenia i był wynagradzany przez parafię. Witrykusi Antoni Szkodowski, Józef Gersz i Maciej Chojnacki. W okresie zimowym organista uczyła dzieci. Akuszerki należycie pouczone, s. 184-185.

Stary przytułek, wymagający naprawy, ale miał zachowany przywilej erekcyjny od Olbrachta Stanisława Radziwiłła z 11 IV 1654 r,., potwierdzonego przez król Jana Kazimierza, i oblatowany w aktach wójtowskich starogardzkich 16 XII 1709 r., s. 185-186.

$\mathrm{D}$ ą b rów ka. Wieś królewska, Z kościołem murowanym, pochodzącym z czasów krzyżackich, pod wezwaniem Podwyższenia Świętego Krzyża, afiliowanym do parafii w Bobowie. Prawo patronatu należy do króla. Opis ołtarzy i wnętrza świątyni. Zakrystia po stronie ewangelii, s. 187.

Spis naczyń srebrnych, pozostałych paramentów liturgicznych i innych sprzętów kościelnych. Nabożeństwa odbywały się w co trzecią niedzielę i w święta. Opis zewnętrzny świątyni. Ogrodzenie cmentarza uszkodzone. Kostnica drewniana. Świątynia utrzymywana jest przez parafian, a parafia składa się jedynie z wsi parafialnej. Ponieważ proboszcz tu nie rezydował, stąd w zabudowaniach plebańskich mieszkali dwaj dzierżawcy, płacący dzierżawę. Cztery łany ziemi proboszczowskiej pozostawało w dzierżawie, s. 187-189.

W ostatnim roku było 9 chrztów i 5ślubów. Na terenie wsi mieszkało 36 luteran. Witrykusi zaprzysiężeni Jan Ossowski, sołtys i Grzegorz Stankiewicz, s. 189.

Dekret reformacyjny dla obydwóch parafii, z dnia 29 października 1765 r., s. 189-191.

K o k o s z k o w y. Wieś królewska ze świątynia parafialną murowaną z ka-

${ }^{185}$ Także w tej parafii była zastanawiająco mała liczba dzieci. 
mienia polnego, pod wezwaniem św. Barbary, inkorporowaną 7 września $1653 \mathrm{r}$. przez biskupa włocławskiego Mikołaja Wojciecha Gniewosza ${ }^{186}$ do konwentu dominikanów z Tczewa. Prawo patronatu należało do króla. Opis wnętrza świątyni, z ołtarzem wielkim zbudowanym w 1740 r. i dwoma ołtarzami bocznymi. Było bractwo różańcowe, s. 192-193.

Wykaz naczyń srebrnych, innych paramentów liturgicznych i pozostałego sprzętu kościelnego. Księgi metryk spisywano. Opis stanu zewnętrznego świątyni. Dzwonnica drewniana, pewnie nadbudowana jako wieża powyżej murów kościoła. Niedawno naprawiano wieżyczkę z sygnaturką. Cmentarz ogrodzony, kostnica stara, znacznie zniszczona, s. 193-194.

Kościół był utrzymywany z ofiar parafii. Należały do niej wsie: Kokoszkowy, Szpęgawsk, Zduny, Ciecholewy, Linowiec, Bączek, folwark Mały Bączek i Zamoście, Krąg, folwark Grabowiec i młyn, Żabno, Okole. Do sakramentów wielkanocnych było zobowiązanych 479 osób. Opis zabudowań plebańskich, częściowo nowych. Na uposażenie były cztery łany ziemi, s. 194-195.

Według zachowanego $\mathrm{w}$ parafii odpisy $\mathrm{z}$ akt włocławskich, sporządzonego 27 I 1633 r., w tej parafii były wówczas dwa kościoły filialne w Linowcu i w Szpęgawsku, które posiadały uposażenie po cztery łany ziemi, ale teraz nie ma ani tych świątyń, ani tego uposażenia. W Szpęgawsku znajdowało się prywatne oratorium, gdzie sprawowano, na podstawie indultu rzymskiego, msze. Było wielu luteran, zwłaszcza we wsi Krąg. Zarządcą kościoła, jeżeli tak można go nazwać, bo nie posiadał odpowiednich dokumentów, był zakonnik dominikanin z Tczewa, Ambroży Kowalkowski. Był przytułek, ale bez specjalnego funduszu, s. 195.

Dekret reformacyjny z dnia 4 listopada 1765 r., s. 196.

$\mathrm{K} 1$ o n ó w k a. dawniej wieś królewska w starostwie gniewskim, a teraz szlachecka Grzegorza Kalksztejna, chorążego chełmskiego. Świątynia murowana pod wezwaniem św. Katarzyny, patronatu wspomnianego Kalksztejna. Opis wnętrza świątyni, z ołtarzem wielkim i trzema bocznymi. Zakrystia murowana po stronie ewangelii, s. 1197-198.

Spis naczyń srebrnych, pozostałych paramentów liturgicznych i innych sprzętów kościelnych, s. 198-200.

Wykaz zobowiązań mszalnych, związanych z zapisami. Księgi metryk spisywano. Opis zewnętrznego stanu świątyni. Dzwonnica, złączona ze świątynią, murowana od dołu, potem z pruskiego muru. Cmentarz ogrodzony z kostnica murowaną. Na naprawy kościoła był zapis 1000 florenów, na dobrach kolatora zabezpieczony, z darowizny Marianny z Kalksztejnów Pawłowskiej, s. 201-202.

Wsie parafialne: Klonówka, Rywald, Nowy Dwór, Lipienki, Mariewil, Najmuzy,Zamoście. Spowiadało sięna Wielkanoc 350 osób. Ostatniemisje były w 1756 r., s. 202-203.

Zabudowania plebańskie, częściowo zniszczone, częściowo odbudowane. Uposażenie stanowiły cztery łany ziemi, z darowizny Marianny Kossowa, wojewodziny chełmińskiej, z 1719 r., zapis czego znajdował się aktach Konsystorza

${ }^{186}$ Biskup włocławski w larach 1642-1654. 
Gdańskiego. Proboszcz miał prawo wyrębu drewna w lasach Klonówka. Wykaz pobieranego mesznego. Inwentarz gospodarczy i dochód proboszcza, s. 203-204.

W ostatnim roku było 33 chrzty i 11 pogrzebów. Parafia liczyła 186 mężczyzn, 329 kobiet, 16 chłopców i 18 dziewcząt. W parafii, we wsi Zamoście znajdowała się synagoga żydowska. We wsi Lipienki byli liczni luteranie, s. 204.

Rektorem kościoła była Wojciech Smaltowski. Bractwo różańcowe, zaprowadzone 23 czerwca 1732 r. z zapisem 500 florenów pruskich na dobrach Zelgoszcz. Organista Tomasz Rojewski. Witrykusi Wojciech Mazurowski i Szymon Derda. Zimą organista uczył dzieci. Akuszerki wystarczająco pouczone. Przytułek nowowstawiony przez dziedzica, chorążego chełmińskiego, ale z funduszy zapisanych przez Mariannę Pawłowską. Było dwóch podopiecznych, s. 204-205.

Dekret reformacyjny, z dnia 5 listopada 1765 r., s. 205-207.

\section{Dekanat tczewski}

D e r s c h a vi a, vulgo T c z e w. Miasto (civitas), z kościołem parafialnym, pięknym, murowanym, pod wezwaniem Świętego Krzyża. Prawo patronatu należało do króla. Opis wnętrza świątyni. W ołtarzu wielkim tabernakulum, ale światło paliło się tylko podczas nabożeństw. Dwanaście ołtarzy bocznych. Zakrystia murowana po stronie ewangelii, s. 208-209.

Spis naczyń srebrnych, paramentów liturgicznych i pozostałego wyposażenia w sprzęty kościelne. Metryki spisywano. Opis stanu zewnętrznego. Dzwonnica murowana, od strony południowej świątyni. Największy dzwon z 1884 r. Przytoczono napisy na dzwonach. Kostnica, przyległa do świątyni murowana. Cmentarz ogrodzony, s. 209-213.

Do utrzymania świątyni było zobowiązane miasto. Nadto były dochody z domów wydzierżawianych. Do parafii, oprócz miasta Tczewa należały wsie: Ciżykowo, Cizykowko, Knybawa, Bałdowo, Czarnin, Śliwiny, Rokitki, Suchostrzele (pewnie Suchostrzygi), Sztembark. Wiernych spowiadających się było 925 osób. Ostatnie misje przed 20 laty. Zabudowania plebańskie i ich opis. Na utrzymanie proboszcza były cztery łany ziemi, ale uszczuplone, tak, iż obecnie nie więcej niż trzy obejmują. ponadto miał on jeszcze pewne dochody z niektórych domów oraz meszne, tu dokładnie wyliczone, s. 213-214.

W ostatnim roku było 66 chrztów, 20 ślubów i 29 pogrzebów. Parafia liczyła 634 mężczyzn, 732 kobiety, 285 chłopców i 325 dziewcząt. Na terenie parafii był klasztor dominikanów. Akatolicy mieli swój zbór, ale chowali się na cmentarzu, gdzie dawniej był kościół św. Jerzego. Luteran było 439, kalwinistów 6 i 8 menonitów, s. 215.

Rektorem kościoła był Wojciech Dembowski, kanonik włocławski i kanclerz kruszwicki ${ }^{187}$. Był także proboszczem w Lubiszewie. Rezydował przy katedrze, dlatego miał tu wikariusza Samuela Rutkowskiego, s. 215.

Było bractwo świętych Aniołów, ale bez własnego uposażenia. Organista Jan

${ }^{187}$ Biogram tego kanonika zob. C h o d y ń s k i, Katalog, s. 198-199, F i u t a k, Prałaci, s. 19. 
Dytlow, Nie było witrykusów. 8 uczniów uczył organista. 8 akuszerek było wystarczająco pouczonych. W przytułku mieszkały dwie wdowy żyjące z jałmużny, bo ten nie miał własnego funduszu, s. 215-216.

L u b i s z e w o. Wieś parafialna z kościołem murowanym, ale wymagającym naprawy, pod wezwaniem Świętej Trójcy i Wniebowzięcia Najświętszej Marii Panny. W ołtarzu wielkim tabernakulum. Dwa ołtarze boczne. Zakrystia murowana po stronie ewangelii, s. 216.

Inwentarz rzeczy świętych, czyli naczyń liturgicznych srebrnych, innych paramentów i pozostałego sprzętu kościelnego. Księgi metryk spisywano. Opis stanu zewnętrznego świątyni. Dwie kaplice. Dzwonnica murowana złączona ze świątynią. Cmentarz ogrodzony, Kostnica murowana, s. 216-220.

Utrzymanie kościoła było powierzone parafianom. Wsie parafialne:L Lubiszewo, Swarożyn, Goszyn, Stanisławie, Liniewko, Zabagnie, Wętkowy, Małżewo, Małżewko, Rukosin, Owczarka, Zwierzynek, Nowymłyn. Wiernych spowiadających się było 764 osoby Nie pamiętano kiedy były ostatnie misje. Opis zabudowań plebańskich i ogrodów. Na uposażenie było osiem łanów ziemi, prawo propinacji, dochody z wynajmu domów i dzierżawy, a także meszne, tu dokładnie wyliczone. Wykaz inwentarza w gospodarstwie, s. 220-222.

Organista był wynagradzany ze skarbony, a także miał inne dochody, w tym od bractwa za śpiewanie oficjum o Opatrzności Boskiej. Przytułek w dobrym stanie z podopiecznymi żyjącymi z jałmużny. Wikariusz, stale tu mieszkający, Michał Zabuszesski, s. 222.

Dekret reformacyjny dla obydwóch kościołów, wystawiony dnia 9 listopada 1765 r., s. 222-224.

S u b k o w y. Wieś biskupa włocławskiego, z kościołem parafialnym, murowanym, pod wezwaniem św. Stanisława. Prawo patronatu należało do biskupa włocławskiego. Opis wnętrza świątyni, ołtarza wielkiego z tabernakulum, przed którym światło paliło się jedynie podczas nabożeństw. Pięć ołtarzy bocznych. Zakrystia murowana po stronie ewangelii, s. 225-226.

Inwentarz zeczy świętych, argentariów, innych paramentów liturgicznych i sprzętów kościelnych. Księgi metryk spisywano. Opis stanu zewnętrznego świątyni. Ogrodzenia cmentarza częściowo murowane, częściowo z drewna, miejscami zepsute. Dzwonnica murowana, przylegająca do świątyni. Kostnica złączona ze świątynią, s. 226-229.

Parafianie byli zobowiązani do utrzymania świątyni. Ponadto był mały dochód z domku wystawionego na placu kościelnym. Wsie parafialne: Subkowy, Radostowo, Bruzce, Wielogłowy, Starzęczyn, Piaski, Słońca Wielka, Gasrc Mały, Narkowy, Fyżbudy, Słońca Mała, Brzeźno, Wacmierz, Wacmierek, Unieszewa, Czarnin, Gorzędziej z kościołem filialnym. Spowiadających się było 1170 osób. Nie pamiętano, kiedy były ostatnie misje. Dom rektora jego kosztem ostatnio zbudowany, gdzie mieszkał wikariusz. Organista mieszkał w szkole. Opis pozostałych zabudowań i ogrodów, s. 228-229/

Na uposażenie były cztery łany ziemi, ale bez łąk. Powiadali, że dawniej były 
trzy łany łąk i jedna dla organisty wśród łąk Miłobądza, ale biskup Czapski zakazał ich użytkowania. Ponadto pewne czynsze i zapis na bractwo Świętego Różańca. Inwentarz gospodarczy s. 229.-230.

Dokładny wykaz dochodów proboszcza, składający się z 4 łqnów w Subkowach, 4 łanów w Gorzędzieju, zapisów, ogrodów, akcydensu i mesznego, którego wielkość tu podano, s. 230.

W ostatnim roku było 70 chrztów, 28 ślubów, 62 pogrzeby. Parafia liczyła 570 mężczyzn, 660 kobiet, chłopców 36 i dziewcząt 34. We wsi Radostowo była kaplica, gdzie odprawiał prokurator konwentu oliwskiego. Luteran było 54 oraz kalwinista, szlachcic Wilamowicz z żoną, s. 230-231.

Rektor kościoła Jetrzy Tokarski, dziekan tczewski, rezydujący na miejscu. Wikariusz Jerzy Wąsinowicz. Organista Michał Kwidziński. Witrykusami byli Jerzy Mania, Andrzej szelski i Wincenty Smugaj. Uczniowie byli jedynie zimą. Akuszerki pouczone, Przytułek stary i zniszczony, ale było pięciu podopiecznych, żyjących z jałmużny, s, 231-232.

G o r z e d z i e j. Wieś z kościołem murowanym pod wezwaniem św. Wojciecha, od 1646 r, afiliowanym do parafii Subkowy. Opis świątyni i jej wnętrza. Wykaz skromnych paramentów liturgicznych i sprzętów kościelnych. Na ziemi parafialnej mieszkańcy wystawili 9 domków, z czego był pewien dochód. Były cztery łany ziemi. Parafia składała się z jednej tylko wsi, s. 232-233.

Dekret reformacyjny dla obydwóch kościołów, z dnia 6 listopada 1765 r., s. 234-236.

M i ł o b a d z. Wieś biskupa włocławskiego. Kościół parafialny, murowany, pod wezwaniem św. Małgorzaty. Opis wnętrza świątyni. Trzy ołtarze. Bractwo Różańcowe. Zakrystia murowana po stronie ewangelii, s. 236-237.

Inwentarz rzeczy świętych, czyli naczyń liturgicznych, paramentów liturgicznych i innych sprzętów kościelnych. Sposób sprawowania liturgii. Proboszcz był zobowiązany do odprawiania czterech mszy tygodniowo za biskupów włocławskich, ponieważ biskup Kazimierz Czartoryski 16 VIII 1664 r., za zgodą kapituły włocławskiej, dał dwa łany na utrzymanie proboszcza, Metryki spisywano dobrze. Opis stany zewnętrznego świątyni. Cmentarz ogrodzony murem, ale ten z niedbalstwa proboszcza w niektórych miejscach uszkodzony, Dzwonnica murowana, podobnie jak i kostnica, s. 237-241.

Kościół powinien być utrzymany przez parafian, ale miał też pewien dochód $z$ dzierżawienia kilku domków i ogrodów, a także pewne zapisy. Podano tu wykaz koszt ów poniesionych z pewnymi inwestycjami, jak sprawienie dwóch dzwonów, naprawę organów i innych, s. 241-242.

Wsie parafialne: Miłobądz, Koling, Muszczyn, Pszczółki, Remblitz, Zenisławki, Łukęcin, Dalwin. Dąbrówka, Zajączkowo, Melenin, Szpęgawa. Spowiadających się było 1130 . Ostatnie misje w 1756 r. przeprowadzone przez zakonników reformatów, s. 242.

Opis zabudowań plebańskich, ogrodów, także zabudowań gospodarczych. Organista mieszkał w szkole, za co płacił parafii. Na utrzymanie były cztery łany 
ziemi, ale praktycznie nieco mniej, a także jeszcze inne role i łąki, tu wyliczone. Było 4 zagrodników mieszkających w damkach należących do proboszcza, zobowiązanych do płacenia czynszu i pracy podczas żniw. Wykaz pobieranego mesznego, s. 242-245.

Opis inwentarza gospodarczego, s. 245-246.

W ostatnim roku było 90 chrztów, 18 ślubów i 39 pogrzebów. Parafia liczyła 571, kobiet 534, chłopców 127 i dziewcząt 153. Zbór innowierców znajdował się we wsi Remblitz i było ich 240. Przebywał tam predykant innowierczy Michał Milda, który, wbrew dawnym zwyczajom, nie dozwalał nawet katolikom mieszkającym w tej wsi przyjmować sakramenty w parafii Miłobądz, s. 246.

Rektorem kościoła był Cyprian Wolicki, prepozyt gnieźnieński i kanonik płocki, oficjał gdański. Wykaz książek, albo parafialnych, albo tegoż Wolickiego. Zarządzał parafią Jan Olszewski, provisus tczewski, wikariuszem zaś był Jan Halba, provisus prangowski (z Rangowa), s. 246-247.

Bractwo Różańcowe, które posiadało swoje paramenty, wyliczone w księdze tegoż, s. 247.

Organista Dawid Jankie, który miał specjalne uposażenia, a za śpiewanie codzienne z ludem różańca, specjale uposażenie w ziemię, z zapisu biskupa Czapskiego. Witrykusami byli Maciej Baszendowski z Dąbrówki, Michał Halba, sołtys z Malenina i Michał Kruza ze wsi Koling. Akuszerki wystarczająco pouczone. Szpital stary, a podopieczni tam mieszkający utrzymują się z jałmużny, s. 247248.

D a 1 w i n. Wieś królewska. Kościół drewniany, bardzo zniszczony, pod wezwaniem św. Mikołaja, afiliowany do parafii Miłobądz. Opis wnętrza świątyni, z ołtarzem wielkim i dwoma bocznymi, ale Najświętszego Sakramentu tam nie przechowywano. zakrystia bliska całkowitej ruinie, s. 248.

Inwentarz paramentów liturgicznych i innych rzeczy kościelnych. Metryki spisywano. Opis stanu zewnętrznego świątyni. Cmentarz ogrodzony, ale niedokładnie, s. 248-249.

Wykaz funduszy kościelnych znajdujących się w skarbonie i źródeł dochodów dla parafii. Da parafii należała jedynie wieś Dalwin. Głównym były cztery łany ziemi, ale aktualnie była tego połowa. Witrykusem tego kościoła był Jan Kęsicki, s. 249-250.

Dekret reformacyjny z dnia 12 listopada $1765 \mathrm{r}$.

G i e m 1 i c e. Wieś stanowiąca własność jezuitów z Gdańska, w której znajdowała się świątynia parafialna, murowana, pod wezwaniem św. Jana Chrzciciela. Opis świątyni, ołtarza z tabernakulum, ale światło paliło się jedynie podczas nabożeństw. Dwa ołtarze boczne. Zakrystia wystawiona w pruski mur po stronie ewangelii, s. 251.

Spis inwentarza rzeczy świętych, czyli liturgicznych naczyń srebrnych oraz pozostałych paramentów liturgicznych i pozostałych sprzętów kościelnych. Księgi metryk spisywano. Opis stanu zewnętrznego świątyni. Dzwonnica, dołem mu- 
rowana, potem drewniana, wymagała naprawy. Cmentarz ogrodzony, z krzyżem misyjnym z 1763 r. Misje przeprowadzili Jezuici. Nie było kostnicy, s. 252-255.

Utrzymanie świątyni należało do parafian. Parafia składała się z jednej wsi, ale do parafii powinny być dołączone wioski blisko położone, jak Menchengrebin, należący do konwentu w Oliwie i Żuadendorf, należący do kartuzów, a położona na wyspie gdańskiej. Spowiadających się na Wielkanoc było 240 osób, ale z wyspy gdańskiej, opanowanej przez luteran, na Wielkanoc przybywa do spowiedzi około 780 osób, proboszcz też nie odmawia wizytowania tam chorych, gdy zachodzi potrzeba. Opis zabudowań plebańskich. Były dwa łany ziemi z łąkami na utrzymanie proboszcza, ale bez lasu. Parafianie jednak dawali dwie kupy drewna. Wykaz mesznego. Inwentarz gospodarski, a także rzeczy znajdujących się na plebanii, w tym kilkanaście książek. Proboszcz pobierał także akcydens. W ostatnim roku było 18 chrztów, 7 ślubów, 22 pogrzeby. We wsi Giemlice luteran naliczono 7, zaś na wyspie gdańskiej 15, s. 255-257.

Proboszcz Andrzej Skwiercz, przy parafii rezydujący. Organista był i pobierał odpowiednie uposażenie, ale nie wymieniono jego nazwiska. Witrykusami byli Jerzy Schulz i Michał Mej. Lampą, przed Najświętszym Sakramentem, opiekował się Jerzy Langmesser. Aktualnie w skarbonie znajdowało Sie 2047 florenów i 15 groszy, zaś na oświetlenie było 397 groszy. Fundusz bractwa (może bractwa różańcowego, bo był ołtarz różańcowy z odpustem) wynosił 729 florenów i 25 groszy. Akuszerki należycie pouczone, s. 257-258.

Dekret reformacyjny z dnia 3 listopada 1765 r., s. 258-259.

S k a r s z e w y. Miasto (oppidum)z kościołem parafialnym (prepozyturalnym) murowanym, który powstał w czasach krzyżackich, ale w 1712 r. Wraz z całym miastem spalił się, jednak szczęśliwie odbudowany, został w 1758 r. konsekrowany przez sufragana chełmińskiego Fabiana Pląskowskiego, pod wezwaniem św. Michała. Prawo patronatu należało do króla. Opis Ołtarza wielkiego, z tabernakulum, przed którym zawsze paliło Sie światło, na co był przewidziany specjalny fundusz. Opis ołtarzy bocznych i wyposażenia wnętrza świątyni. Nowe organy sprawiono w 12750 r. Przy tym kościele była kaplica pod wezwaniem św. Jana Nepomucena, wystawiona w 1752 r. Zakrystia murowana po stronie ewangelii, s. 260-262.

Spis rzeczy świętych, to znaczy naczyń liturgicznych srebrnych, pozostałych paramentów liturgicznych i sprzętów kościelnych. Metryki spisywano. Był zapis 300 florenów, uczyniony przez Macieja Wybickiego, uczyniony po śmierci jego żony, Konstancji z Pruszków, na mszę za jej duszę i zmarłych z domu Wybickich, zabezpieczony na jego dobrach rodzinnych Mikorzyn. Opis stanu zewnętrznego świątyni. Dzwony znajdujące Sie wmurowanej dzwonnicy złączonej ze świątynią, zostały po pożarze przywiezione z filialnego kościoła w Dęblinie. Był tam dawniej kościół pod wezwaniem św. Małgorzaty. Cmentarz ogrodzony z kostnica murowaną, s. 262-265.

Wykaz uposażenie kościoła, na co składały się ofiary parafian, łan ziemi z zapisu pochodzącego z 1642 r., z trzech kawałków ziemi zwanych Halsztuki oraz całego szeregu innych dochodów, tu wymienionych. Do parafii należały wsie: 
Chamierowo, Chamierowskie Piece, Mierowo, Dęblin, Nygut, Zapowiednik, Czarnocin, Czarnowskie Piece, karczma zwana Czystawoda, folwark probostwo, Watachowo, Cylka, nowe kolonie miejskie Wilk i Krawusino, Szczodrowo, młyn Szczodrowienie, Englert, Pawłowo, Pawłówko, Celmerostwo, Nowy Wietc, Świnie Budy, Bełt Huta, Sucha Huta, Sztruk Huta, Czasz Huta, Górne Piekło, Olszowe Błoto, Granicznik. Nowa kolonia starostwa skarszewskiego, Pruskie karczmy Max i Brumsdorf oraz Nowa Kolonia Gdańska. Ponieważ w tych wsiach jedynie czwarta część stanowią katolicy, stąd do sakramentów wielkanocnych było jedynie 898 osób. W roku, gdy była wizytacja, przeprowadzili misje reformaci, s. 265-267 .

Opis zabudowań plebańskich, wystarczających także dla wikariuszu i czeladzi. Utrzymanie tego należało do miasta. Organista też miał dom, do którego odbudowania i napraw było zobowiązane miasto. Opis pozostałych zabudował gospodarskich i ogrodów. Do prepozytury skarszewskiej należał folwark zwany Prepozytura. Opis jego położenia. Był także cały szereg innych źródeł dochodów, jak 20 domów i browar. Jak mówi stary przywilej jeszcze z czasów krzyżackich, do kościoła należało sześć łanów ziemi oraz szereg innych. Mniejszych pól, a także łąk, dokładnie wymienionych, s. 267-272.

Wykaz dosyć szczegółowy dochodów prepozyta, w tym także poobijanego mesznego z poszczególnych wsi. Wykaz inwentarza gospodarskiego, s. 272-273.

W ostatnim roku było 103 chrzty, 24 śluby, 47 pogrzebów. Dorosłych mężczyzn naliczono 407, kobiet 450, chłopców 219 i dziewcząt 238. Innowiercy luteranie, których było 1713 osób, mieli w Skarszewach swój zbór. Żydzi, w niepodanej liczbie, dzierżawią mieszkania od zarządu zamku, s. 273.

Rektorem był Bazyli Złocki, archidiakon pomorski, który zatrudniał w Skarszewach dwóch kapłanów, a miaan0owicie zarządcę Andrzeja Sztoba i wikariusza Jana Zarębę. Było też tu bractwo św. Anny, ale bez fundacji. Promotor bractwa (nie podano, który z księży nim był), miał fundusz na odprawianie mszy brackich w drugi dzień suchych dni kwartalnych, zapisany w 1689 r. przez ówczesnego proboszcza berneńskiego (z Kościerzyny), Laurinowicza. Organista Jan Sieczewski miał na utrzymanie łan ziemi, a także inne dochody, w tym od bractwa. O stan szkoły, czyli mieszkania organisty troszczyło Sie miasto. Uczniów rzadko było więcej niż 12, ponieważ w mieście katolicy stanowili mniejszość. Prowizorami było Franciszek Maliszewski i Jan Nytz, mieszczanie skarszewscy i Marcin Gącza z folwarku prepozyturalnego. Akuszerki dostatecznie pouczone. Przytułek, czyli szpital, dawniej stary, na który były zapisy został przez poprzedniego prepozyta odbudowany i w nim przebywało 8 podopiecznych, s. 273-275.

S z c z o d r o w o. Wieś z kościołem parafialnym drewnianym, pod wezwaniem Szymona Judy i Tadeusza, ostatnio od fundamentów naprawianym i odrestaurowanym. Opis stanu wewnętrznego świątyni, z ołtarzem wielkim ostatnio nowo sprawionym i dwoma ołtarzami bocznymi. Zakrystia drewniana po stronie ewangelii, s. 275.

Inwentarz rzeczy świętych, czyli paramentów liturgicznych, naczyń srebrnych 
i pozostałego sprzęty kościelnego. Opis stanu zewnętrznego świątyni. Na uposażenie były cztery łany ziemi, znajdujące się w dzierżawie, s. 275-277.

Dekret reformacyjny dla i obydwóch kościołów [Skarszew i Szczodrowa], $\mathrm{z}$ dnia 7 grudnia $1765 \mathrm{r}$.

Tr ą b k i W i e 1 k i e. Świątynia murowana, fundowana przez Konstancje Czapską, wojewodzinę pomorską, pod wezwaniem Matki Bożej. Prawo patronatu należało do króla. Opis wnętrza świątyni, z nowym ołtarzem Matki Boskiej, w którym znajdowało się tabernakulum, ale wieczna lampa pali się jedynie podczas nabożeństw. Było bractwo różańcowe. Opis pozostałych trzech ołtarzy bocznych. Zakrystia murowana po stronie ewangelii, s. 278.

Wykaz rzeczy świętych, czyli inwentarza naczyń liturgicznych srebrnych, innych paramentów i sprzętów kościelnych. Opis nabożeństw. Wyposażenie wnętrza świątyni. Metryki spisywano należycie. Dzwonnica wystawiona w pruski mur. Cmentarz ogrodzony, Niekiedy chowają się na nim luteranie, s. 278-281.

Do utrzymania świątyni byli zobowiązani z prawa i zwyczaju parafianie. Do parafii należały wsie: Trąbki Wielkie, Klempiny, Sobowidz, Posztołowo, Elganowo. Do sakramentów wielkanocnych było zobowiązanych 364 osoby. Ostatnie misje w 1749 r., s. 281-282.

Opis zabudowań proboszczowskich, odbudowanych w 1762 r. i domu organisty z 1755 r. oraz zabudowań gospodarskich. Uposażenie proboszcza składało się z czterech łanów ziemi, dochodów z dwóch domów i procentów od zapisanej sumy tysiąca florenów z darowizny kasztelanowej Marianny Czapskiej. Proboszcz pobierał meszne. Niebyło inwentarza, ponieważ parafia przez długi czas była złączona jako filialna z parafią w Kłodawie. W ostatnim roku było 26 chrztów, 5 ślubów i 5 pogrzebów. Mężczyzn naliczono tu 179, kobiet 185, chłopców 100 i dziewcząt 106. Luteran było 60, s. 282-283.

Rektor kościoła Michał Wąsinowicz, rezydujący na miejscu, Organista Maciej Tokarski. Witrykusi zaprzysiężony Jan Makowski z Posztołowa i Michał Bielski z Elganowa. Uczniowie byli tylko w porze zimowej, Akuszerki należycie przygotowane, s. 283-284.

Dekret reformacyjny z dnia 4 grudnia 1765 r. s, 284,

G o d z i s z e w o. Wieś opata z Lądu. Dawny kościół z pruskiego muru uległ zniszczeniu i zastąpiono go nowym, murowanym, wystawionym w 1747 r., pod wezwaniem św. Jana Nepomucena. Przywilejem papieskim z 1456 r. parafia inkorporowana do opactwa w Lądzie i opat tegoż był kolatorem parafii. Opis wnętrza świątyni z ołtarzem wielkim w ostatnim roku wystawionym, Lampa przed Najświętszym Sakramentem paliła się dzień i noc. Opis wnętrza świątyni i czterech ołtarzy bocznych. Zakrystia murowana, s. 285-286.

Spis inwentarza, srebrnych naczyń liturgicznych, pozostałych paramentów liturgicznych i sprzętów kościelnych, s. 286- 288.

Bractwo powroza św. Franciszka ${ }^{188}$ z przywilejami odpustowymi i bractwo

${ }^{188}$ Tam można przetłumaczyć wyrażenie: „confraternitas Chordigerorum s. Francisci”. 
różańcowe, któremiałozapis fundacyjny uczyniony przezJerzegoi MariannęzKalkszteynów Bystramów wynoszący 600 florenów pruskich, zabezpieczony na dobrach Gołembiewo. Były pewne obligi odprawiania przez rektora kościoła mszy fundowanych. Opis wnętrza świątyni i jej stanu zewnętrznego. Metryki spisywano należycie. Dzwonnica złączona ze świątynią. Cmentarz ogrodzony z kostnica z pruskiego muru, 288-290.

Do parafii należały wsie: Godziszewo, Damaszka, Boroszewo Wielkie, Boroszewko Małe, Szwagrowie, Gołębiewo Średnie, Żygowicze, Obozino, Jastrzębie, Janino, Kaszmirowo, Scinsko, Bujary, Gołęmbiewo Wielkie, Roszciszewo Wielkie, Gołębiewo Małe, Kobierzyn, Szierbięncin, Rozciszewko, Turze Wielkie, Turze Małe. Wiernych spowiadających się było 760 osób, s. 290.

Zabudowania plebańskie, gdzie i wikariusz mieszkał z pruskiego muru wystarczające. Dom dla organisty nowy i pozostałe zabudowania plebańskie, w tym i gospodarcze. Na uposażenie kościoła (pewnie proboszcza) były trzy łany ziemi, opłata czynszu z jednego domu w wysokości 30 florenów oraz meszne z wsi parafialnych, tu dokładnie wyliczonych oraz z akcydensu. W ostatnim roku było 65 chrztów, 18 małżeństw, 18 pogrzebów. Ogółem katolików i luteran było mężczyzn 396, kobiet 494, chłopców 189 i 299 dziewcząt. Luteranie nie mieli stałego miejsca nabożeństw. Oratoria prywatne jedno w Gołębiewie Średnim, posiadłości Bystramów, a drugie we wsi Ścisk, należącej do franciszkanów. Kaplica, czyli kościół, w Obozinie, o czym niżej, s. 290-291.Rektor, czyli zarządca Antoni Libaber, zakonnik cysters i wikariusz oraz kaznodzieja, jego współbrat, Edmund Paszczyński. Był organista i dwaj Witrykusi, nie wymienieni z nazwiska. Akuszerki należycie przygotowane, Przytułek, niedawno zbudowany z siedmioma podopiecznymi, s. 290-292.

O b o z i n o. Wieś dziedziczna Cecylii z Pawłowskich Sartowskiej. Kaplica, a raczej prywatny kościół, z wieżą, wystawiony z solidnego muru, pod wezwaniem św. Michała Archanioła. Świątynia została zbudowana przez Jana Loka, dziedzica wsi, po zniszczeniu (raczej zniesieniu) świątyni luterańskiej. Wspomniany Loka dał na utrzymanie kuratora Godziszewskiego, bo do tej parafii ta świątynia została dołączona, trzy łany ziemi, jednak później ziemia ta wróciła do użytkowania przez dziedziców z Obozina, którzy wypłacali kuratorowi Godziszewskiemu 20 florenów. Zresztą były specjalne umowy pomiędzy dziedzicami Obozina a proboszczem Godziszewskim Benedyktem Starzyńskim z 1653 r., czy Janem Libaber, kuratorem Godziszewskim z 1750 roku. Aktualnym kapelanem był Dominik Szpęgl, dominikanin. Opis wnętrza świątyni z nowym ołtarzem i dwoma bocznymi, s. 292-293.

Wykaz paramentów liturgicznych, s. 293-294.

Opis wnętrza świątyni i wygładu zewnętrznego, s. 294-295.

Dekret reformacyjny z dnia 5 XII 1765, s. 295-296.

W y s i n. Wieś bpa włocławskiego, z kościołem drewnianym, starym i wymagającym naprawy, pod wezwaniem Wszystkich Świętych. Prawo patronatu należało do biskupa włocławskiego. Opis wnętrza świątyni z ołtarzem wielkim ku 
czci Chrystusa Ukrzyżowanego, z tabernakulum, ale światło paliło się jedynie podczas nabożeństw. Było bractwo szkaplerza świętego z przywilejem odpustowym. Trzy ołtarze boczne, s. 297.

Inwentarz paramentów liturgicznych i naczyń srebrnych oraz pozostałych sprzętów kościelnych. Sposób sprawowania nabożeństw. Księgi metryk spisywano akuratnie. Stan zewnętrzny świątyni, na fundamencie z kamieni, ale ściany wymagały naprawy. Dzwonnica oddzielona od świątyni. Ogrodzenie cmentarza uszkodzone, Kostnica nowa drewniana, s. 297-300.

Parafianie byli odpowiedzialni za naprawę kościoła z tradycji i z obowiązującego prawa. Proboszcz pobierał 8 florenów czynszu z jednego domu. Do parafii należała jedynie wieś Wysin $\mathrm{z}$ folwarkiem. Wiernych spowiadających się było 436b osób, s. 300.

Opis zabudowań plebańskich, drewnianych. Także takiego samego domu dla organisty oraz zabudowań gospodarskich. Proboszcz (kościół) miał na utrzymanie sześć łanów ziemi i łąki. Pobierał także meszne $\mathrm{z}$ wsi i beczułkę piwa $\mathrm{z}$ folwarku Skrzydłowskiego. W ostatnim roku ochrzczono 44 osoby i pochowano 6. Katolików było 577 osób, zaś luteran 272, s. 300-301.

Proboszcz Mikołaj Wilma, posiadający jedno beneficjum. Organista niepodanego imienia posiadający łan ziemi z łąka i 12 florenów zapłaty. Dwóch witrykusów, także niepodanego imienia, s. 301.

Dekret reformacyjny z dnia 9 XII 1765, s, 301-302.

$\mathrm{N}$ i e d a m o w y ${ }^{189}$. Wieś dziedziczna Klińskich. Świątynia drewniana, chyląca się ku upadkowi, pod wezwaniem św. Mikołaja i Marii Magdaleny. Prawo patronatu należało do Klińskich. Ołtarz wielki nowy, z tabernakulum, przed którym jedynie podczas nabożeństw paliło się światło. Były relikwie Krzyża Świętego. Bractwo różańcowe. Cztery ołtarze boczne. Opis wnętrza świątyni, Zakrystia drewniana, niedawno naprawiana, s. 303-304.

Inwentarz paramentów liturgicznych i naczyń srebrnych oraz pozostałych sprzętów kościelnych. Anna Klińska pozostawiła zapis na odprawianie mszy św. $\mathrm{w}$ intencji wyznaczonej, co czynił proboszcz. Był także zapis na bractwo. Od siedmiu lat żaden z tych zapisów nie przynosił dochodu. Księgi metryk spisywano. Opis stanu zewnętrznego świątyni, znajdującej się w kiepskim stanie, s. 304-306 .

Utrzymanie świątyni należało do kolatora, ale ten ostatnio się zaniedbywał. Wsie parafialne: Niedomowy, Homerbag, Stawiska, Małe Polesie, Wielkie Polesie, Dembogóry, Smolniki, Luboń, ponadto nowa kolonia Barembarg i jeden dom z wsi Sarnowy. Dawniej, jak to wynikałoby z metryk, do parafii należała wieś Rakownica z kościołem filialnym, ale przed koło 27 laty, przeszła do parafii Grabowo. Na Wielkanoc spowiadało się około 400 wiernych. Nie ma wiadomości, kiedy były ostatnie misje, s. 306.

Zabudowanie plebańskie wystawił kolator Kliński. Organista nie miał własnego domu. Zabudowania gospodarcze. Uposażenie składało się z czterech łanów,

${ }^{189}$ Obecnie pisze się „Niedomowo. 
ale czwarta część nie nadawała się do użytku.. $\mathrm{Z}$ ta ziemia sąsiadowała łąka. Proboszcz pobierał meszne, ty wyliczone. Spis inwentarza gospodarskiego, s.306308.

W ostatnim roku ochrzczono 30 osób, ślubów było 5, pogrzebów 20. Mężczyzn naliczono 200, kobiet 216, chłopców 90 - dziewcząt 80, s. 308.

Rektor kościoła Stanisław Wylma, zarządca. Organista był, ale nie podano imienia. Utrzymywała go parafia oraz posiadał trzy morgi ziemi za obowiązek śpiewania różańca. Akuszerki były należycie poinstruowane, s. 308.

Dekret reformacyjny z dnia11 grudnia $1765 \mathrm{r}$.

Wykaz dłużników kościoła w Niedamowie. Zwrotu domaga się zarządca parafii i przeznacza to na kościół, s. 310.

G a r c z y n. Wieś dziedziczna Jana Tuchotka. Prezbiterium świątyni murowane, zaś nawa główna z pruskiego muru. Kościół pod wezwaniem Świętej Trójcy. Prawo patronatu należało do dziedzica Tuchotka. Opis świątyni z ołtarzem wielkim, gdzie było tabernakulum, przed którym światło paliło się dzień i noc. Dwa ołtarze boczne. Zakrystia murowana, s. 311.

Spis inwentarza rzeczy świętych, naczyń srebrnych, pozostałych paramentów liturgicznych i sprzętów kościelnych. Metryki spisywano akuratnie. Opis stanu zewnętrznego kościoła. Dzwonnica z pruskiego muru. Cmentarz tylko częściowo ogrodzony. Drewniana kostnica wymagała naprawy, s. 312-314.

Utrzymanie świątyni należało do parafian. Wsie parafialne: Garczyn, Orle, Krtowo, Równe, Lobończ, Liniewko, Lubiszyn, Płachty, Liniewo, nowe kolonie Rubostwo i Lubieszynko. Na Wielkanoc spowiadało się 309 osób. Misje były w bieżącym roku i przeprowadzili je misjonarze z kościoła św. Wojciecha, s. 314.

Opis zabudowań plebańskich, częściowo zniszczonych. Na uposażenie były cztery łany, ale częściowo zniszczone. Był też las, położony blisko kościoła i rezydencji proboszcza, ale Michał Tuchotka, za poprzedniego proboszcza, dla wyrównania (ulepszenia), włączył do swoich posiadłości. Wykaz pobieranego mesznego. Ogólny dochód miał wynosić 422 floreny. W ostatnim roku było 52 chrzty, 6 ślubów i 33 pogrzeby. Ogółem parafia liczyła 151 mężczyzn, 130 kobiet, 150 chłopców i 118 dziewcząt. We wsi Orle było prywatne oratorium, gdzie na mocy indultu Konsystorza gdańskiego, można było odprawiać mszę, ale z zachowaniem prawa parafialnego. Luteran naliczono 344 osoby, s. 314-316.

Rektorem kościoła był Wawrzyniec Franciszek Ksawery Bałachowski, nieposiadający innego beneficjum. Wystarał się o przywilej zaprowadzenia bractwa Bożej Opatrzności. Organista Michał Pniewski, osiadający swoje uposażenie. Witrykusi Stanisław Lesiński, Jan Pniewski Jakub Niebroza i Adam Chajewski. Akuszerki były wystarczająco pouczone, s. 316-318.

Dekret reformacyjny z dnia 14 grudnia 1765 r., s. 318-320. 


\section{[Cześć druga księgi]}

Visitatio Generalis Ecclesiarum Archidiaconatus Pomeraniae, Decanatuum Maevensis et Neoburgensis, per Perillustrem et Admodum Reverendum Dominum Bartholomeum Franciscum Xaverium Trochowski, insignis Collegiatae Crusviciensis canonicum Officialem Swecensem, Praepositum Serocensen, ab Domino Domino Antonio Casimiro Ostrowski, Episcopo Wladislaviensi et Pomeraniae, Delegatum Commissarium et Deputatum Visitatorem Generalem, in Anno Domini Millesimo Septingentesimo Sexagesimo Sexto expedia, s. 321.

M a e v a, vulgo G n i e w. Świątynia murowana, fundowana w czasach krzyżackich, w stanie dobrym, pod wezwaniem św. Mikołaja. Prawo patronatu należało do monarchy, s. 323.

Odpis przywileju erekcyjnego parafii i prepozytury w Gniewie, wystawionego w Warszawie, przez króla Władysława IV ${ }^{190}$, dnia 6 grudnia 1646 r., z insertem dokumentu z 1507 r., wystawionego przez króla Zygmunta [Starego] ${ }^{191}$, poświadczający dawne przywileje od książąt pomorskich otrzymane oraz uposażenie parafii w wyspę na rzecze Wiśle, zwaną Kuchnia i wieś tam się znajdująca, a także jeszcze inne uposażenie, s. 323-325.

Opis wnętrza świątyni, a więc ołtarza wielkiego, fundowanego przez księcia Radziwiłła, starostę gniewskiego, gdzie znajdowało się tabernakulum, jednak lampa paliła się tam jedynie podczas sprawowania mszy. Opis pozostałych siedmiu ołtarzy i wyposażenia świątyni. Zakrystia po stronie lewej ołtarza wielkiego. Dwa instrumenty organowe, s. 325-326.

Spis inwentarza, bardzo bogaty, a więc naczyń srebrnych i pozostałych paramentów liturgicznych, w tym także książek w ilości około 70 woluminów, nie tylko liturgicznych, ale i teologicznych, s. 326-334.

Dwa bractwa, a więc Świętego Różańca, zaprowadzone za zgodą Zaporskiego $^{192}$, kanonika włocławskiego i oficjała włocławskiego i gdańskiego oraz i św. Anny, zaprowadzone za aprobatą biskupa włocławskiego Gniewosza ${ }^{193}$, s. 334.

Spis inwentarza własności bractwa różańcowego, a więc paramentów liturgicznych, także bardzo licznych, s. 334-338.

Spis inwentarza bractwa św. Anny, s. 338-339.

Wykaz zobowiązań płynących z pobożnych zapisów oraz sposób sprawowania służby bożej. Opis stanu wewnętrznego i zewnętrznego świątyni. Kaplica św. Anny. Księgi metryk chrztów, ślubów, pogrzebów, a także dochodów i wydatków prowadzono dokładnie. Ogrodzenie cmentarza uszkodzone i powinni naprawić to

${ }^{190}$ Władysław IV. Król Polski w larach 1632-1648. Biogram tego króla zob. Stownik biograficzny historii powszechnej do XVII stulecia, Warszawa 1968, s. 466-467.

${ }^{191}$ Zygmunt I Stary. Król Polski w latach 1506-1548. Biogram tego króla zob. Stownik biograficzny historii powszechnej do XVII stulecia, Warszawa 1968, s. 482-483.

${ }^{192}$ Zapewne Teodor Zaporski, kanonik włocławski, zmarły w 1652 r. Biogram tego kanonika zob. C h o d y ń s k i, Katalog, s. 1071-1073.

${ }^{193}$ Mikołaj Gniewosz z Oleksowa, biskup włocławski w latach 1642-1654. 
mieszczanie. Dzwonnica częściowo murowana, częściowo drewniana. Jeden wielki dzwon zabrano do przelania w Gdańsku, s. 339-341.

Do mieszczan należała dbałość o świątynię. Był poważny zapis 12000 florenów uczyniony przez Barbarę Niewieścińską, a zabezpieczony na dobrach niejakiego Jakuba Pincek, na procent 6 od 100, a także inne jeszcze zapisy i dochody, jak z czterech domów dających czynsz. Był także pewien dochód na przytułek s. 341.

Oprócz miasta z przedmieściami i zamku, należały do parafii wsie: Ciepłe, Gronowo Wielkie i Małe, Gronówko, Cierpicki Dwór, Brody Niemieckie, Młyn Zamkowy, Nicponia. Za rzeką Wisłą Bursztach, Nowe Lichnowy, Jansdorf, Wielkapastwa, GniewskiemPole, Kacza Kępa, Foswinkiel, Kamrowskie Dwory, Gutz, Szałwinek, Szulfcza, gdzie byli memmonici, Małe Pólko. Ponadto należały dwie wyspy, Pazurowa Kepa i Stagweltowa. Te wsie oddawały meszne. Wsie Gronowo i Kuchnia, według dokumentu erekcyjnego miały należeć do prepozyta gniewskiego, jednak z biegiem czasu starostowie gniewscy pozbawili ich tych posiadłości. Spowiadających się na Wielkanoc było 1895 osób. Ostatnie misje przeprowadzili jezuici z Bydgoszczy w 1765 r., s. 341-342.

Opis zabudowań plebańskich, dla rektora, czyli prepozyta, częściowo odbudowanych od nowa przez miasto. Tam też mieszkał wikariusz. Był dom dla organisty i służby kościelnej. Były i inne zabudowania parafialne oraz gospodarcze. Opis uposażenia proboszcza, na które składało się 6 łanów ziemi, łąki i ogrody. Lasu nie było, ale proboszcz posiadał prawo wyrębu drewna w lasach starostwa gniewskiego. Ponadto prawo propinacji w dwóch karczmach oraz czynsz z 23 domów, dający 134 floreny dochodu. Do tego należy dodać wiele zapisów, tu wyliczonych, s. 342-344.

Inwentarz gospodarczy, żywy i martwy oraz sprawozdanie z wysiewów i plonów, s. 344-345.

W ostatnim roku pochrzczono114 dzieci, oprócz dzieci innowierców, które były chrzczone w zborze. Zagubiono 32 pary, także oprócz małżeństw innowierców oraz pochowano 57 osoby, także nie licząc zmarłych luteran, których chowano na wyznaczonym dla nich miejscu przy bramie gdańskiej oraz w innych trzech miejscach na terenie parafii. Dorosłych katolików naliczono: mężczyzn 644, kobiet 744, chłopców 174 i dziewcząt 174, s. 345.

Była kaplica, zwana prepozyturą szpitalną położona za bramą, przy drodze wiodącej do młyna, pod wezwaniem św. Jerzego, a przy niej cmentarz. Druga kaplica na zamku, która miała powstać w czasach krzyżackich, jak to niosła tradycja. Innowiercy posiadali swój zbór w mieście, gdzie odprawiał po niemiecku i po polsku ich pastor, a ponadto mieli swoje szkoły, gdzie uczyli ich nauczyciele. Innowiercy płacili jednak proboszczowi rocznie 125 florenów tytułem akcydensu. Luteran było około dwóch tysięcy oraz jeden kalwinista z żona. Menonitów, mieszkających nad Wisłą było około 140 osób, s. 345-346.

Proboszcz Michał Dąbrowski, kanonik poznański. Oprócz wspomnianej kanonii, posiadał jeszcze parafię Tymawa, jako filialną parafii Gniew. Było dwóch wikariuszy. Michał Perkowski i Józef Dubiszewski. Trzeci wikariusz Maciej Litwiński mieszkał przy kościele filialnym w Tymawie. Organista i nauczyciel, tak- 
że obowiązki kantora spełniający, z odpowiednim uposażeniem, dokładnie wyliczonym. Jakub Głowiński. Odpis przywileju Jana III [Sobieskiego], wystawionego w warszawie, dnia 12 III 1689 r., potwierdzający postanowienie królewskie z 10 XI 1688 r., że przy kościele w Gniewie, dla większej chwały Bożej, mają być zatrudnieni muzycy. Powinni oni być także wykorzystywani przy innych okazjach i mają pierwszeństwo przed innymi, a nad tym ma czuwać burmistrz i sołtysi. Należało wybrać witrykusów. Akuszerki były we wszystkich wsiach dostatecznie pouczone, s. 346-350.

Przytułek, czyli szpital, z pruskiego muru, znajdujący się przy bramie wodnej wewnątrz murów miejskich. Do jego naprawy był zobowiązany magistrat. Dokładny wykaz uposażenia. Aktualnie było 18 podopiecznych, s. 350.

Wykaz 71 dokumentów, z krótkimi regestami, jakie znajdowały się w parafii, s. 350-354.

T y m a w a. - kościół filialny. Świątynia wystawiona w pruski mur, naprawiana staraniem Januszewskiego, ale przedstawiająca zły widok, pod wezwaniem św. Michała, konsekrowana w 1665 r. przesz sufragana żmudzkiego [Stanisława Jacka] Święcickiego ${ }^{194}$. Opis wnętrza, ołtarza wielkiego i jednego bocznego. Wykaz paramentów liturgicznych, jak na kościół filialny, dosyć licznych. Do tego kościoła ciągnęły wsie: Tymawa, Jazwizka, Rakowiec i Aplinki Małe, Wykaz pobieranego mesznego, Dom zarządcy dosyć zniszczony. Zarządcą był ksiądz Maciej Litwiński, s. 354-357.

Dekret reformacyjny dla parafii w Gniewie i dla kościoła filialnego Tymawa, z dnia 21 maja 1766 r., s. 357-360.

P i a s e c z n o. Świątynia parafialna murowana, z dwiema kaplicami, niedawno wzniesionymi. Po stronie południowej kaplica pod wezwaniem św. Józefa i po stronie północnej Batki Bożej z góry Karmel, która została wzniesiona przez członków bractwa Szkaplerza w 1759 r. Sama zaś świątynia nowi wezwanie narodzenia Najświętszej Marii Panny. Prawo patronatu należało do króla. Opis świątyni z pięknym drewnianym ołtarzem, w którym znajdował się obraz Matki Bożej, słynący łaskami, ozdobiony koronami i za taką uznana przez biskupa włocławskiego Wojciecha Gniew, co potwierdza odpowiedni dokument z 27 VII 165o r., wystawiony przez Konsystorz Gdański. Opis wnętrza świątyni z sześcioma ołtarzami bocznymi. Zakrystia po stronie ewangelii murowana, s. 361-363.

Inwentarz rzeczy świętych, czyli naczyń liturgicznych, pozostałych paramentów liturgicznych, szat i pozostałego wyposażenie, bardzo bogatego. Na fundusz parafialny i na śpiewanie oficjum o Matce Boże, Wojciech Stanisław i Krystyna z Lubomirskich Radziwiłłowie, zapisali w 1648 r, co potwierdzili potem królowie Jan Kazimierz i August II, cztery łany ziemi, z czego trzy użytkował proboszcz, a jeden organista, Opis sprawowanych nabożeństw. Wykaz pozostałych sprzętów kościelnych. Metryki spisywano. Opis stanu zewnętrznego świątyni. Dzwonnica, na której znajdował się zegar założony w roku ubiegłym [1765]. Cmentarz ogrodzony murem. Kostnica, s. 363-374.

${ }^{194}$ Biogram tego biskupa zob. N i t e c k i, Biskupi Kościoła katolickiego, k. 440. 
Dochód kościoła był z akcydensów, a ponadto 60 florenów z mesznego ze wsi: Piaseczno, gdzie także proboszcz miał siedem łanów i organista jeden łan ziemi, Jelenie, folwark Bilsk, folwark Wyrąby. Na Wielkanoc do spowiedzi było 373 osoby. Ostatnie misje w 1748 r., s. 374.

Plebania drewniana, w 1710 r. zbudowana. Organista od kilku latmieszkaw szpitalu. Zakrystianin miał domek przy kościele, w którym mieszkał także jeden wieśniak. Opis pozostałych zabudowań i ogrodów. Była także pasieka oraz kolka domków, z których pobierano czynsz. Z zapisu Radziwiłłów, wyżej wspomnianego były cztery łany ziemi, a także inne4 cztery łany, z których dochód przeznaczony był na śpiewanie oficjum o Matce Bożej. Łąk nie osobnych nie było, ani lasu, ale proboszcz posiadał prawo wyrębu drewna $\mathrm{z}$ lasów starostwa gniewskiego, jak to wynikało z dokumentu z 1598 r. Ponadto każdy z kolonistów był zobowiązany dawać pewna ilość drewna, ale od pewnego czasu nic nie poddają, a nawet próbuje się zanegować prawo wyrębu. Był także staw, a raczej jezioro z prawem połowy ryb, oraz prawo propinacji. Wykaz mesznego z wsi parafialnych oraz zapisów, s. 375-377.

Wykaz inwentarza gospodarczego, s. 377.

W ostatnim roku było 28 chrztów, osiem ślubów i 14 pogrzebów. Ogółem w parafii naliczono mężczyzn 184, kobiet 189, chłopców 97 i dziewcząt 72 . Luteran było 7, s. 377 .

Proboszcz Adam Niesiołowski, dziekan gniewski, zawsze rezydujący na miejscu. Wykaz książek znajdujących się przy parafii w liczbie około 10. Wikariusz Kazimierz Bruski. Organista Paweł Reymer, który był też nauczycielem. Zakrystianin Jakub Stepa. Witrykusi Stanisław Małkowski z Piaseczna i Andrzej Krąg z Jelenia. Akuszerki poinstruowane. Przytułek przed kilkoma laty odbudowany z czterema małymi pomieszczeniami, ale własnego uposażenia nie miał, za wyjątkiem 2 florenów płaconych $\mathrm{z}$ domku wystawionego na gruncie szpitalnym, s. 377-379 .

O p a 1 e $\mathrm{n}$ i e. Kościół filialny, wystawiony w pruski mur, znacznie zniszczony, pod wezwaniem św. Apostołów Piotra i Pawła, konsekrowany w 1662 r. Prawo patronatu należało do Jakuba Czapskiego, właściciela dóbr Misterwald i Opalenie. Opis wnętrza świątyni, z ołtarzem wielkim, w którym rzadko jest przechowywany Najświętszy Sakrament. Dwa ołtarze boczne. Inwentarz rzeczy świętych, czyli naczyń liturgicznych srebrnych, innych paramentów liturgicznych i rzeczy kościelnych, s. 379-381.

Wsie parafialne: Opalenie, Misterwald, Aplinki Wielkie, Aplinki Małe, Widlice, Podgórze, Dębowy Las, Przewóz. Do spowiedzi wielkanocnej było 273 osoby. Opis zabudowań plebańskich. Na uposażenie były cztery łany ziemi, ale aktualnie dwa łany włączył do gruntów folwarcznych niejaki Wolf. Łąk były cztery morgi. Nie ma zapisanego żadnego inwentarza. Proboszcz miał na uposażenie owe dwa, wyżej wymienione łany, będące w dzierżawie, z czego otrzymywał czynsz 130 florenów, a także meszne, s. 381-182. 
Dekret reformacyjny dla obydwóch kościołów Piaseczno i Opalenie, z dnia 22 maja 1766 r., s. 382-386.

Inwentarz rzeczy świętych, naczyń liturgicznych, innych paramentów liturgicznych i sprzętów kościelnych. Sposób sprawowania nabożeństw. Z tytułu zapisu fundacyjnego proboszcz był zobowiązany do odprawiania mszy w każdy piątek za fundatorów. Księgi metryk spisywano. Opis zewnętrznego stanu kościoła. Cmentarz ogrodzony z kostnica murowaną, s. 388-391.

Uposażenie kościoła składało się z czynszów z kilku domów, łanu ziemi zapisanego przez księcia Radziwiłła we wsi Pączewo. Do parafii należała jedynie wieś Pączewo i Wolental. Do spowiedzi wielkanocnej, razem z parafii i kościoła filialnego Czarnolas, było904 osoby. Ostatnie misje rozpoczęły się podczas niniejszej wizytacji i były prowadzone przez zakonników reformatów, s. 391.

Ponieważ plebania była stara, stąd aktualny proboszcz wystawił nową, zaś starą dał dla służby. Dla wikarego przygotowano mieszkanie w pomieszczeniu przytułku. Dom dla organisty znacznie zniszczony. Inne zabudowania plebańskie i ogrody. Uposażenie składało się z czterech łanów ziemi. Nie było łąk. Proboszcz posiadał prawo wyrębu drewna $z$ lasów starostwa oraz miał mały staw. Meszne pobierał z Pączewa i wsi Wolental. Inwentarz gospodarczy. Proboszcz miał jeszcze dodatkowo cztery łany ziemi przy kościele w Czarnymlesie, s. 391-393.

W ostatnim roku było 64 chrztów, w tym 35 chłopców i 29 dziewcząt, ślubów 10 i 41 pogrzebów. Nie było luteran, s. 393.

Rektor Jan Gręca, posiadający jeszcze parafię w Czarnymlesie, będącą parafią filialną. Miał też wikariusza, Paulina Latoszewicza, zakonnika dominikańskiego z konwentu tczewskiego. Organista Mateusz Puczyński, który był też nauczycielem i miał odpowiednie uposażenie. Witrykusi zaprzysiężeni Jan Bąkowski i Józef Seliski. Akuszerki odpowiednio poinstruowane. Przytułek nowy, wystawiony przez parafię, a w nim trzy wdowy, ale nie miał własnej fundacji, s, 393-394.

C z a r n y l a s. Kościół od dawna przyłączony do parafii w Pączewie. Murowany jeszcze w czasach krzyżackich, w stanie dobrym. Nosił wezwanie św. Andrzeja i św. Mateusza Apostołów. Opis wnętrza świątyni. Było bractwo św. Józefa, zaprowadzone staraniem Bystrama, wicewojewody pomorskiego, ale nie miało własnego uposażenia. Ponadto znajdowały się cztery ołtarze. Zakrystia murowana, s. 374-375.

Inwentarz rzeczy świętych, naczynia srebrne, pozostałe paramenty liturgiczne, s. 395-397.

Na utrzymanie kościoła były akcydensy, a także czynsz z trzech domów. Dochód proboszcza składał się z czterech łanów ziemi, aktualnie będących w dzierżawie i czynszów z domów. Ponadto meszne z wsi Czarnolas, młyna Wda i z karczmy Wda, a wsi Cermet, Długie, Gęby, Ziemianek, ale te ostatnie nic nie dawały. Luteran było $4 \mathrm{w}$ młynie. Zabudowania plebańskie odbudował aktualny proboszcz. Inwentarza gospodarczego tu nie było. Organista Z Pączewa miał tu dom, s. 397.

Dekret reformacyjny dla obydwóch parafii z dnia 3 maja 1766 r. 
$\mathrm{D}$ z i e r z ą z n o. Wieś kapituły włocławskiej. Kościół murowany bardzo stary z 1096 r., ale już zewnątrz i wewnątrz bardzo zniszczony i chylący się ku ruinie, ale jak Fenix z popiołów, tak po niszczejącym kościele powstaje nowy, na który kapituła, z tytułu swojego prawa patronatu, przeznaczyła już pewne materiały budowlane. Dawny kościół był z pewnością konsekrowany i nosił tytuł św. Jakuba Większego. Opis wnętrza świątyni. Zakrystia stara drewniana. Dzwonnica stara na cmentarzu, drewniana. Kostnica na cmentarzu w tym roku wystawiona, s. 400-401.

Inwentarz rzeczy świętych, naczyń liturgicznych srebrnych, innych paramentów liturgicznych i pozostałych przedmiotów kościelnych. Sposób sprawowania służby Bożej, s. 401-404.

Fundusze na utrzymanie budynku kościelnego zależą od hojności kapituły, zaś wewnętrzny wystrój i bieżące potrzeby od składem parafian. Wsie parafialne dające meszne: Dzierzążno, Gogolewo, Polskie Brody i osada młyńska. Na Wielkanoc spowiadało się 300 osób. Nie było wiadomym, kiedy miały miejsce ostatnie misje. Opis zabudowań plebańskich, s. 404-405.

Inwentarz miejscowy gospodarski. Dochód proboszcza stanowiły cztery łany ziemi, dochód z czynszów od domków oraz z akcydensu, s. 405.

W parafii było trzech ewangelików w karczmie Stawiska. Zarządca parafii był niepodanego imienia Turski. Organista Adam Makowski, s. 405.

Dekret reformacyjny z dnia 5 maja 1766 r., s. 406.

$\mathrm{N}$ e o p h a n i a, czyli N o w a c e r k i e w. Wieś opata z Pelplina. Świątynia nowa, murowana, wytrawiona staraniem opata Izydora Tokarzewskiego, pod wezwaniem matki Bożej Królowej Apostołów, świętych Apostołów Piotra i Pawła oraz św. Mateusza. Prawo patronatu należało do opata pelplińskiego i tegoż konwentu. Opis wnętrza świątyni i starego ołtarza [pewnie ze starego kościoła]. Ołtarzy bocznych sześć, w tym także w kaplicy będącej pod opieką bractwa różańcowego i drugiej św. Jana Nepomucena. Zakrystia po stronie ewangelii, murowana, s. 407-408.

Inwentarz paramentów liturgicznych i pozostałych sprzętów kościelnych, s. 408-410.

Wykaz zapisów, z których były zobowiązania odprawiania mszy, s. 410.

Dalszy wykaz sprzętów i wyposażenia świątyni oraz książek. Opis zewnętrznego stanu. Dzwonnica niedawno wystawiona. Cmentarz ogrodzony murem i nowa kostnica, s. 410-411.

Uposażenie samej świątyni było jedynie z ofiar przy pogrzebach oraz z czynszu z czterech domków należących do kościoła, co dawało po 20 florenów rocznie, s. 411.

Wsie parafialne: Nowacerkiew, Rozental, Kulice, Genomie, Morzeszczyn, Rzerzecin, Królówlas z kościołem filialnym oraz folwarki Ropuchy, Bielawki, Ronnenberg, Wolsza i Borkowo z osadą młyńską. Wiernych spowiadających się na Wielkanoc było 1209 osób. Ostatnie misje przeprowadzili reformaci w 1756 r., s. 411-412.

Domy dla zarządcy i wikariusza z pruskiego muru, zaś dom dla organisty, 
położony blisko kościoła, służył mu jako mieszkanie i jako miejsce, gdzie uczył dzieci. Inne zabudowania plebańskie i inwentarz gospodarski. Dochód proboszcza składał się z czterech łanów ziemi, z akcydensów, z dwóch łanów znajdujących się przy kościele we wsi Królówlas i z mesznego pobieranego ze wsi obydwóch parafii. Ponadto pobierał meszne z wsi, tu wyliczonych. We dobrach wsi Borkowo znajdowała się kaplica, którą także odwiedził wizytator, s. 4`12.

Zarządcą parafii był Wojciech Raczyński, zakonnik cysters, wikariuszem zaś także zakonnik Krzysztof Pawłowski. Organista, niepodanego imienia. Witrykusi: Paweł Tobia i Michał Kałamarski. Trzy akuszerki odpowiednio pouczone. Mały przytułek, bez własnego uposażenia, z czterema ubogimi, żyjącymi z jałmużny. Bractwo Różańcowe, zaprowadzone w 1623 r., bez własnego uposażenia, s. 412413.

K r ó 1 ó w 1 a s. Kościół filialny, należący do parafii w Nowacerkiew, prawa patronatu opata, niedawno odbudowany z pruskiego muru. Klucze przechowywane u witrykusów. Cztery ołtarze. Opis wnętrza świątyni. Zakrystia z pruskiego muru. Wykaz dosyć skromnych paramentów liturgicznych. Meszne z jednej wsi Królówlas. Ponadto na utrzymanie tego kościoła był jeden łan ziemi, s. 413-414.

Dekret reformacyjny dla obydwóch parafii z dnia 6 maja 1766 r., s. 414-416.

P e 1 p 1 i n. W tej wsi, należącej do opactwa cysterskiego i gdzie znajdowała się rezydencja opata i samo opactwo, był też kościół przeznaczony dla sprawowania duszpasterstwa, czyli parafialny, murowany, pod wezwaniem Bożego Ciała, zbudowany w 1418 r., jak to wynikało z tablicy znajdującej się w murze świątyni. Prawo patronatu należało do opata. Opis stanu wewnętrznego świątyni. Było bractwo Aniołów Stróżów, s. 417-418.

Inwentarz rzeczy świętych, a więc naczyń srebrnych liturgicznych, innych paramentów liturgicznych i sprzętów kościelnych, w tym także należących do bractwa Aniołów Stróżów. Opis nabożeństw. Księgi metryk spisywano Opis stanu zewnętrznego kościoła. Do parafii, poza wsią parafialną i folwarkiem zwanym Wola, należącym do opata, nie należały żadne. $Z$ ksiąg metryk natomiast wynikało, że należały do tej parafii wsie: Rozental, Ropuchy i Bielawki. Na Wielkanoc spowiadały się 393 osoby. W pobliżu kościoła dom dla organisty, gdzie uczył także dzieci, ale jedynie w okresie zimowym. Przy parafii nie buło żadnej ziemi. Rektorem kościoła był Fabian Ustarbowski, zakonnik, rezydujący w klasztorze. Witrykusami byli Michał Fordoński z Pelplina i Piotr Tylcek ze wsi Pomyje ${ }^{195}$. Akuszerki zostały przeegzaminowane ze znajomości udzielania sakramentu chrztu. Szpital murowany, bez własnego funduszu, ale utrzymywany przez opactwo, a w nim siedmiu mężczyzn i trzy niewiasty, s. 418-421.

Dekret reformacyjny z dnia 7 maja 1766 roku, s. 421-422.

R a j k o w y. Kościół parafialny, murowany, pod wezwaniem św. Bartłomieja, konsekrowany przez sufragana włocławskiego Ignacego Bardzińskiego ${ }^{196} \mathrm{w} 1721$

\footnotetext{
${ }^{195}$ Wsi tej nie wyliczono ani w poprzedniej parafii, ani w wykazie parafii Pelplin.

${ }^{196}$ Biogram tego sufragana zob. C h o d y ń s k i, Biskupi sufragani włoctawscy, s. 67-69.
} 
roku. Prawo patronatu należało do króla. Opis wnętrza świątyni, zakrystii ze skarbcem, s. 4523-424.

Inwentarz rzeczy świętych, naczyń srebrnych i pozostałych paramentów liturgicznych, s. 424-426.

Wykaz pobożnych zapisów, z czego należało odprawiać msze w wyznaczonych intencjach, s. 426.

Porządek nabożeństw w kościele. Wykaz pozostałego wyposażenia świątyni. Opis stanu zewnętrznego kościoła. Dzwonnica przyległa do Kocioła murowana. Cmentarz ogrodzony murem i kostnica z pruskiego muru, ale zniszczona, s. 426427.

Utrzymanie kościoła należało do parafii, a uzupełnieniem był grunt zwany Skrzypiec, z czego był roczny dochód 12 florenów, a ponadto czynsze z pięciu domków dający rocznie 30 florenów. Były dochody z pogrzebów, a także ze wsi Harbuda ${ }^{197} 21$ groszy, ale dochód ten ostatnio nie wpływał. Do parafii należało jedynie wieś Rajkowy. Do sakramentów wielkanocnych było zobowiązanych 364 osoby, s. 427,

Zabudowania rektora nowe, z 1758 r., wystawione staraniem parafian. Należało także wznieść nowy dom dla organisty, do czego także parafianie byli zobowiązani. Stan pozostałych zabudowań plebańskich. Wieśniacy zamieszkujący owych pięć domów należących do parafii, byli zobowiązani do odpracowania proboszczowi w Czasie żniw po trzy dni. Parafianie zamierzają odbudować stary dom szpitalny, gzie aktualnie mieszkał jeden wieśniak. Proboszcz miał cztery łany ziemi z dodatkami, ale piaszczyste. Ponadto prawo wyręby drewna z lasów starostwa gniewskiego. A i parafianie ze zwyczaju na święta Bożego narodzenia dawali po wozie drewna, ale od pewnego czasu tego zaprzestali. Meszne z wsi Rajkowy i młyna, s. 428-429.

Bractwo Różańcowe, zaprowadzone przez dominikanów z Tczewa, z pewnym funduszem zapisanym przez Krzysztofa Freychel, młynarza z Rajkowych, zabezpieczonym na dobrach Szprudowo, s. 429.

Inwentarz gospodarczy, dokładny, s. 429-430.

Uposażenie proboszcza składało się z czterech łanów ziemi, mesznego, akcydensów przy pogrzebach i przy asystowaniu przy ślubach, a także zwyczajowo na świętego Marcina pewne świadczenie, chleb i gęś, co zwano kłos, s. 430.

Rektor Mikołaj Kuchłowski, zawsze na miejscu rezydujący. Witrykusi, wybrani i zaprzysiężeni podczas wizytacji, Michał Makowski, Szymon Lamek i notariusz zaprzysiężony, Jerzy Niklas. Uczniowie pobierali naukę jedynie w zimę. Akuszerki wystarczająco pouczone. Organista Tomasz Lipiński. Opis jego uposażenia, s. 430-431.

Dekret reformacyjny z dnia 10 maja 1766 roku, s. 431-433.

G a r c z. Świątynia murowana, jak wieść niosła, podchodząca jeszcze z czasów krzyżackich, pod wezwaniem Niepokalanego Poczęcia Najświętszej Marii Panny, która, jak to stwierdza wizytacja z czasów biskupa Rozdrażewskiego,

${ }^{197}$ Trudno określić jednak, czy to była wieś, czy jakiś budynek tylko. 
przez czas pewien znajdowała się w rękach innowierców. Prawo patronatu należało do króla. Opis wnętrza świątyni. Było bractwo Różańcowe, s. 433-434.

Inwentarz rzeczy świętych, srebrnych naczyń, innych paramentów liturgicznych i sprzętów kościelnych, s. 434-436.

Wykaz zobowiązań odprawiani mszy z pobożnych zapisów. Sposób sprawowania nabożeństw. Bractwo Różańcowe, zaprowadzone i uposażone przez Mariannę z Kalkszteynów Pawłowską w 1737 r. Wykaz własności tego bractwa, s. 436-437.

Wykaz pozostałych sprzętów kościelnych, w tym ksiąg liturgicznych. Opis stanu zewnętrznego kościoła. Utrzymanie świątyni należało tak z prawa, jak i ze zwyczaju, do parafian. Ponadto był czynsz 16 florenów z domku należącego do parafii, ale ten domek znajdował się w ruinie, s. 437-438.

Wsie parafialne: Garcz, Rudno, Gręblin, Miedzyłąż. Na Wielkanoc do spowiedzi przystępowało 561 osób. Nie pamiętano, kiedy były ostatnie misje. Opis zabudowań proboszczowskich, mieszkalnych i gospodarczych. Do ich ewentualnej odbudowy byli zobowiązani parafianie. Jedynie wieś Międzyłąż uparcie od tego się wzbrania. Do uposażenia proboszcza należały cztery łany, ale brakowało do pełnego areału 18 mórg. Nie było lasów, ale prawo wyrębu drewna. Prawo pobierania mesznego, ale i tego wzbraniała się oddawać wieś Międzyłąż. Dokładny wykaz sprzętów gospodarczych oraz inwentarza żywego. Wykaz opłat za posługi religijne proboszcza. Mieszkańcy Międzyłęża płacili więcej. Opłaty wnosili także luteranie. We wsi Rudno znajdował się zbór innowierczy, zbudowany niedawno z pruskiego muru, przy którym był minister luterański, sprawujący nabożeństwa w języku niemieckim i polskim. We wsi Gręblin mieli innowiercy swój cmentarz. Jednakniektórzyinnowiercychowalisięnacmentarzuparafialnymwmiejscu wyznaczonym. Ogółem katolików było więcej niż luteran i dochodziło ogółem do około tysiąca osób, s. 438-441.

Rektor kościoła Józef Żurkałowski, kanonik kruszwicki ${ }^{198}$, penitencjarz w Żarnowcu, ale nie rezydował w parafii. Wikariusz Maciej Redmerowski. Organista Maciej Grzeszkowski. Trzej witrykusi, akatolicy zaprzysiężeni ${ }^{199}$, po jednym z każdej wsi: Ze wsi garcz Michał Brehmer, z Rudna Andrzej Delfk i z Gręblina Jakub Librych: Uczniów bardzo mało i tylko zimą. Akatolicy posiadali swoich nauczycieli w każdej wsi. Akuszerki wystarczająco pouczone, s. 441-443.

Dekret reformacyjny z dnia 12 maja 1766 roku, s. 443-445.

L i b n o w y $\mathrm{y}^{200}$. Kościół murowany, jak powiadają z czasów krzyżackich, pod wezwaniem św. Marcina i św. Małgorzaty. Prawo patronatu należało do monarchy. Opis stanu wewnętrznego świątyni i ołtarzy. Było bractwo, ale nie podano, pod jakim wezwaniem, s. 446-447.

Inwentarz rzeczy świętych, srebrnych naczyń liturgicznych, pozostałych paramentów liturgicznych i sprzętów kościelnych. Sposób sprawowania nabożeństw.

\footnotetext{
${ }^{198}$ Tego kanonika kruszwickiego nie zna w swoim opracowaniu ksiądz Antoni Fiutak.

${ }^{199}$ Nie można pojąc, dlaczego podano, że to akatolicy.

${ }^{200}$ To obecna parafia Lignowy.
} 
Pozostałe sprzęty kościelne. Opis stanu zewnętrznego. Cmentarz ogrodzony murem. Kostnica, s. 447-450.

Opis uposażenia kościoła. Do jego utrzymania byli zobowiązani parafianie, ale mieszkańcy wzbraniali się od tego, jednak wizytator stwierdził, że perswazją przyczynił się do tego, iż można się spodziewać, że naprawia dach świątyni. Kościół miał pewne fundusze z 24 mórg ziemi i łąk zapewne, co otrzymał jeszcze w 1345 r. od Hermana Kudorn, krzyżackiego zarządcy w Gniewie, oraz z 6 mórg w Bursztynie, co dawało po jednym florenie z morgi. Do parafii należały wsie: Libnowy, Szprudowo, gdzie znajdował się kościół, czyli kaplica, Bursztyn, Janiszewo, Pomyje. Wiernych spowiadających się było 520 osób, s. 450-451.

Opis zabudowań plebańskich. Należy zaznaczyć, że do odbudowy i napraw tych zabudowań byli zobowiązani parafianie, wg zwyczajem uznanego porządku, tu przedstawionego. Uposażenie proboszcza składało się z czterech łanów ziemi, siedem morgów łąk, także łąki zwanej Łąka Szynwezy. Ponadto w Janiszewie, gdzie dawniej był kościół, jak to wynika z dokumentu zawierającego przywilej z czasów krzyżackich i z wizytacji z czasów biskupa Rozdrażewskiego, były także cztery łany. Do tego należy dodać stawy. Meszne pobierano z wsi: Libnowy, Bursztyn, Pomyje, Janiszewo, Szprudowo, s. 451-454.

Bractwo, ale niepodano jego wezwania, posiadało własne obrazy bogato ozdobione w sukienki srebrne, s. 454.

Inwentarz gospodarczy, gdzie wyliczywszy zwierzęta i odwoławszy się do spisanego inwentarza, powtórzono wiadomość o łanach ziemi w Lubnowach i w Janiszewie, a nawet obliczono $\mathrm{w}$ przybliżeniu dochód proboszcza $\mathrm{w}$ pieniądzu. Księgi metryk należycie spisywano. Wyliczono także księgi liturgiczne, s. 455.

S z p r u d o w o. Kościół, a raczej kaplica, gdzie odprawiano w co trzecia niedzielę. Nie przechowywano Najświętszego Sakramentu. Kaplica była murowana, pod wezwaniem św. Szymona i Judy Tadeusza, z dwoma ołtarzami. Opis kaplicy, s. 455-456.

Spis inwentarza kaplicy w Szprudowie, s. 456.

W parafii było dużo luteran i wyliczono wsiami, gdzie byli i w jakim stosunku do katolików, s. 456.

Rektorem kościoła w Lubnowach był Antoni Lipiński, kanonik kruszwicki ${ }^{201}$, sędzia surogat przy oficjale gdańskim, częściowo w Gdańsku, częściowo w parafii rezydujący. Wikariusz Józef Rejznerowski. Organista Jan Zblewski. Witrykusi Paweł Mena, Jakub Pułnat i Gabriel Cyma. Przy kościele w Szprudowie Witrykusem był Marcin Mena. Uczniów było sześciu i może uczył organista. Akuszerki zaprzysiężone, s. 456-457.

Dekret reformacyjny z dnia 14 maja $1766 \mathrm{r}$.

W a 1 i c h n o w y. Świątynia zbudowana częściowo z solidnego muru, częściowo z muru pruskiego, pod wezwaniem św. Jana Chrzciciela, prawa patronatu królewskiego. Opis stanu wewnętrznego i zewnętrznego kościoła, którego wiel-

${ }^{201}$ Biogram tego kanonika zob. F i u t a k, Prałaci i kanonicy kruszwiccy, s. 58v. 
kość określono w łokciach ${ }^{202}$. Wieża i zakrystia murowane. Opis ołtarzy, s. 461-462 .

Inwentarz rzeczy świętych, naczyń i innych paramentów srebrnych, pozostałych paramentów liturgicznych i rzeczy kościelnych, bardzo licznych. Księgi metryk spisywano. Opis stanu zewnętrznego świątyni. Dzwonnica złączona z kościołem. Cmentarz z ogrodzeniem z drewna, podzielony na dwie części dla chowania katolików i akatolików, Kostnica murowana, s. 463-468.

Kościół nie posiadał specjalnego funduszu i do naprawy byli zobowiązani parafianie. Wsie należące do parafii: Walichnowy Wielkie, Walichnowy Małe, Kuchnia, Rozgardy, w pobliżu tej wsi znajdowała się wysepka na Wiśle, zwana Lasek. Na Wielkanoc spowiadały się 354 osoby, s. 468.

Opis zabudowań plebańskich, dla proboszcza, wikariusza, organisty i szkoły, oraz gospodarskich. Były trzy łany ziemi, dosyć dokładnie opisane, a pośród nich (podano, że miały być cztery łany ${ }^{203}$ ) znajdowało się łąk około 36 mórg. Były też inne dochody, w tym także meszne ze wsi. Z zapisu testamentowego Marianny Pawłowskiej ze wsi Klonówka, był procent od 500 florenów, z przeznaczeniem na odprawianie mszy. Spis inwentarza gospodarczego, s. 468-470.

Powtórzono, że dochód proboszcza składał się z czterech łanów ziemi, łąk, ogrodów, mesznego, czynszów i akcydensów, 470.

W ostatnim roku ochrzczono 46 dzieci, pobłogosławiono 8 par małżeńskich i pochowano 29 zmarłych. Katolików było 311, zaś luteran 129. Podano dosyć dokładnie, w jakich wsiach mieszkali innowiercy, s. 470.

Rektorem kościoła był Jan Jakub Kwyng. Wykaz kilkudziesięciu ksiąg, głównie liturgicznych. Wikariusz Jan Wolf. Organista Paweł Kurowski. Dwóch witrykusów, niepodanych imion, było luteranami a jeden katolik. Uczniowie uczyli się tylko w zimę, bo latem wypasali bydło. Akuszerki przygotowane, s. 471-472.

Dekret reformacyjny z dnia 16 maja $1766 \mathrm{r}$.

\section{Następuje dekanat nowski}

$\mathrm{N}$ e o b u r g u m, vulgo $\mathrm{N}$ o w e. Miasto (oppidum) założone jeszcze w czasach krzyżackich, otoczone murem w 1185 r. przez Przybysława, księcia pomorskiego. Kościół prepozyturalny, murowany, fundowany razem z miastem, pod wezwaniem świętego Mateusza Apostoła i Ewangelisty. Prawo patronatu należało do króla. Opis wnętrza świątyni i jej ołtarzy. Niektórymi ołtarzami opiekowały się cechy rzemieślnicze. Obraz matki Boskiej w jednym z ołtarzy bocznych uchodził za łaskami słynący, ze srebrna sukienka i wotami. Zakrystia murowana, s. 475-477 .

Inwentarz rzeczy świętych, srebrnych naczyń i innych sprzętów, pozostałych paramentów liturgicznych i rzeczy kościelnych, stosunkowo licznych. Sposób sprawowania liturgii, a więc odmawiano niektóre godziny liturgiczne. Istniało bractwo różańcowe, które też miało swoje nabożeństwa. Pousiadało ono własne

${ }^{202}$ Jest to raczej sporadyczny przypadek.

${ }^{203}$ Wiadomość o czterech łanach potwierdzono w dalszej części protokółu. 
uposażenie, tu wyliczone, ale sukcesorzy tych, którzy pobrali zapisy na procent, nie chcieli płacić, stąd proboszcz wytoczył im proces. Ponadto były zapisy, tu wyliczone, na odprawianie mszy za wskazane osoby, s. 477-481.

Stan wnętrza świątyni. Księgi metryk spisywano. Opis stanu zewnętrznego kościoła. Do napraw świątyni byli zobowiązani parafianie, szczególnie mieszczanie. Ponadto były specjalne zapisy, z czego procent szedł na utrzymanie kościoła, ale nie zawsze zz tego obowiązku się wywiązywano, s. 481-483.

Do parafii należały wsie: Morgi, Trill, folwark Kończyce, Rybaki, Krożałek, Kozielec, Bocklin, Mieliwko, Rychława, Kamionka, Mieliwe, Zawada, Łabęcki, Białobłotki, Głodowo, Osiny, Żabiak, Blęzawy, Montasek, Zdroje, Grabowa Góra, Huta. Do sakramentów na Wielkanoc przystępowało 1052 osoby. Ostatnie misje w 1765 r., przeprowadzone przez misjonarzy od św. Wojciecha z Gdańska, s. 483.

Stan zabudowań plebańskich, dokładnie opisanych. Uposażenie składało się z ogrodów, czynszów z jedenastu domów należących do parafii, czterech łanów ziemi i łąk. Nie było lasów, ale proboszcz posiadał prawo wyrębu drewna w lasach starostwa. Staw. Wykaz pobieranego mesznego. Inwentarz gospodarczy. Dochód proboszcza składał się z ziemi, łąk, mesznego, czynszów i akcydensów, s. 483-484.

W ostatnim roku ochrzczono 125 dzieci, pobłogosławiono małżeństwo 25 par i pochowano 35 osób. Mężczyzn było 500, niewiast 409, chłopców 109 i dziewcząt 150 , s. 484-485.

W mieście był klasztor franciszkanów obserwantów, z 19 zakonnikami. We wsi Mieliwe znajdowała się kaplica prywatna, murowana, w ogrodzie, z ołtarzem i prawem sprawowania tam mszy, którą odprawiał jeden z zakonników franciszkanów z Nowego. Ponadto w mieście był zbór innowierczy, ale nie było go w żadnej z wsi parafialnych. Szkoły we wsiach Mieliwko, Rychława, Trill i Morgi. Żydów w parafii było 47, luteran i menonitów około 900, s. 485.

Rektor kościoła Andrzej Chaliński, kanonik płocki, ale tu nie rezydował, a tylko niekiedy się zjawiał. Wikariusz Jacek Brzezicki, jednocześnie promotor bractwa i kaznodzieja. Organista Antoni Ogórkowski, który miał odpowiednie uposażenie. Kantorem i nauczycielem, zapewne w szkole w mieście, a także zakrystianinem, był Michał Grendowski, także posiadający odpowiednie uposażenie, powiększone jeszcze o zapłatę za opiekowanie się zegarem na wieży kościoła. Jeden witrykus zaprzysiężony, ale nie wymieniony z nazwiska. Uczniów w mieście około 12. Akuszerki, w liczbie ośmiu, dostatecznie poinstruowane, s. 485$-486$.

Przytułek jeden poza miastem, mający pewne uposażenie, z sześcioma podopiecznymi, a także kościółek mały pod wezwaniem św. Jerzego, z ogrodzonym cmentarzem. Drugi przytułek w mieście, w pobliżu kościoła, dla starych mieszczan, a aktualnie znajdował się jeden mieszczanin bardzo ubogi, nawrócony, z żoną. Wieśniacy potrzebujący pomocy mieszkają w różnych pomieszczeniach, ale otrzymują pomoc. Szpital ten posiadał swoje uposażenie. Nad funduszami oby 
dwóch szpitali czuwają prowizorowie miejscy i zdają z tego sprawozdanie, s. 486-487 .

Dekret reformacyjny z dnia 24 kwietnia 1766 r., s. 487-491.

S k ó r c z. Wieś z kościołem murowanym, pod wezwaniem Wszystkich Świętych i Niepokalanego Poczęcia Najświętszej Marii Panny. Opis wnętrza świątyni z jej trzema ołtarzami, s. 492-493.

Inwentarz rzeczy świętych, srebrnych naczyń liturgicznych, innych paramentów liturgicznych i sprzętów kościelnych. Były zapisy na msze fundowane za fundatorów, poczynione przez Bledzewskich i przez dawnego proboszcza Manteckiego. Korzystał z tego proboszcz i organista z racji odprawianych mszy. Sposób sprawowania liturgii, Wyposażenie wnętrza świątyni oraz opis jej stanu zewnętrznego w dobrym stanie. Dzwonnica drewniana. Cmentarz z kostnicą, dobrze ogrodzony, s. 493-497.

Utrzymanie świątyni należało do parafian oraz był też na to fundusz zapisany w 1673 r. przez proboszcza ze Skórcza, Stanisława Kitowicza, co zapisano w aktach oficjała gdańskiego, czego odpis był przechowywany w parafii. Ponadto były cztery domy. Zapis Pawła Kitowskiego, sołtysa z Wielbrądowa z 1721 r., Jana Romanowskiego, z 1760 r., Macieja Fankidej z 1764 r. i inne, s. 497-498.

Wsie parafialne: Skórcz, Wielbrądowo, Osiek i folwarki: Karszenek, Kozie, Skrzynia, Kasperus, Błędno, Suchobrzeźnica, Radogość, Trzebiechowo, Szlaga, Łuby, Dębiegóry, Wycinki, Wymysłowo, Zajączek, Głuche, Czerwonezdrowie. Wiernych spowiadających się na Wielkanoc było 850 osób. Ostatnie misje przeprowadzone przez misjonarzy z parafii Święty Wojciech miały miejsce przed szesnastoma laty, s. 498.

Opis zabudowań plebańskich i uposażenia proboszcza, w tym sześć łanów ziemi, ogrody, łąki, wolny wyręb drewna z lasów starostwa osieckiego oraz wolny połów ryb w jeziorze Głuche i w stawie we wsi Skórcz i jeszcze inne świadczenia. Ponadto dziesięcinę i meszne z wyżej wymienionych folwarków, s. 499-500.

Przy parafii działało bractwo Miłosierdzia, które posiadało w Skórczu jeden łan ziemi, oraz drugi łan będący w dzierżawie dający roczny dochód, z czego były msze za członków bractwa sprawowane w poniedziałki każdego tygodnia, s. 500 .

Inwentarz gospodarczy i powtórny wykaz uposażenie proboszcza, do czego dochodziło jeszcze sześć łanów z tytułu opieki nad parafią Grabowo, do parafii w Skórczu inkorporowanej., s. 500-501.

W ostatnim roku było 70 chrztów, z czego 31 chłopców i 39 dziewcząt, 14c ślubów oraz 35 pogrzebów, a więc 14 mężczyzn, 3 kobiety, 10 chłopców i 8 dziewcząt, s. 501,

We wsi Osiek znajdowała się kaplica, postała z fundacji starosty osieckiego Łochockiego, kasztelana dobrzyńskiego, pod wezwaniem św. Rocha, gdzie było zezwolenie na sprawowanie nabożeństw co trzy lub cztery tygodnie. W parafii było mężczyzn luteran 11 i 10 kobiet, s. 501.

Rektor kościoła Jan Łabiński, kanonik lwowski, dziekan starogardzki, który posiadał także afiliowana parafie Grabowo, rezydujący na miejscu. Miał on, 
oprócz ksiąg liturgicznych, także inne książki do kazań, rozwiązywania kazusów i ascetyczne. Wikariusz brat Porfiriusz z zakonu Braci mniejszych z Nowego. Organista Jan Żelewski, z należytym uposażeniem, Akuszerki w poszczególnych wsiach należycie pouczone. Przytułek znacznie zniszczony, ale w nim mieszkają, pomimo zagrożenia, trzej mężczyźni i trzy kobiety, s. 502.

G r a b o w o. Kościół filialny; wystawiony z pruskiego muru, z przyległą dzwonnica. Nie podano jego wezwania. Cztery ołtarze dobrze wyglądające. Zakrystia dobrze zamknięta, s. 502-503.

Inwentarz rzeczy świętych. Cmentarz dobrze ogrodzony. Dochód proboszcza z sześciu łanów ziemi, o czym było już wyżej, teraz w dzierżawie. Wykaz innych dochodów proboszcza z tej parafii, s. 503-504.

Dekret reformacyjny dla obydwóch parafii z dnia 16 kwietnia 1766 r., s. 504-506 .

$\mathrm{J}$ a $\mathrm{n}$ i a $\mathrm{K}$ o ś c i e $1 \mathrm{n} \mathrm{a}^{204}$. Wieś $\mathrm{z}$ kościołem murowanym, wystawionym w 1622 r, przez Piotra Kostkę Szteinberk, podkomorzego chełmińskiego, dziedzica tej wsi, pod wezwaniem św. Józefa i św. Mikołaja, . Wieża pochodziła jeszcze z czasów krzyżackich. Świątynia konsekrowana w 1681 r. przez Macieja Łubieńskiego $^{205}$. Prawo patronatu aktualnie należało do Nieborskich. Opis stanu świątyni, trzech ołtarzy. Zakrystii mutowanej położonej za wielkim ołtarzem. Przy kościele tym było bractwo Świętej Trójcy, zaprowadzone w 1748 r., ale bez specjalnego funduszu, s. 508-509.

Inwentarz rzeczy świętych, naczyń liturgicznych srebrnych, innych paramentów liturgicznych i obrazów. Sposób sprawowania służby bożek. Księgi metryk spisywano. Stan zewnętrzny świątyni. Ogrodzenie cmentarza wymagało naprawy, s. 509-512.

Utrzymanie świątyni, zgodnie ze zwyczajem, należało do kolatora i parafian. Wsie parafialne: Jania Kościelna, Jania Stara, Jania Leśna, folwarki Pustkowia, Kowwnatka, Bobrowiec, Grabowiec, Nicponia, Komorze, Naszczerz, Okarpiec, Słuchacz, Na Wielkanoc spowiadało się 438 osób. Ostatnie misje odbyły się w 1762 r. prowadzone przez reformatów, 512 .

Opis zabudowań plebańskich, mieszkalnych i gospodarczych. Na utrzymanie kościoła było cztery łany ziemi, ale ostatnio ilość ta się zmniejszyła i było zaledwie około trzy łany. Nie było oddzielnych łą. Proboszcz posiadał prawo wyrębu drewna w lasach kolatora. Miał też czynsz z domów. Ponadto meszne w wsi, tu wyliczone. Były tez niewielkie zapisy, niejakiej Czerwińskiej, z czego korzystał też proboszcz miejscowy odprawiając msze oraz miejscowy szpital. Inwentarz gospodarczy żywy. Jeszcze raz wymieniono dochód proboszcza, s. 512-513.

W ostatnim roku było 11 chrztów chłopców i 19 dziewczynek, pobłogosławiono cztery pary małżeńskie oraz pochowano 8 osób dorosłych i 13 małoletnich. Luteran było 11 mężczyzn i 11 kobiet, s. 513-514.

${ }^{204}$ Obecnie nazwa brzmi: Kościelna Jania.

${ }^{205}$ Jest tu oczywisty błąd. Maciej Łubieński był biskupem włocławskim w latach 1631-1641, a potem przeszedł na arcybiskupstwo gnieźnieńskie. Może przez pomyłkę kopista księgi zapisał cyfrę 8 zamiast 3 . 
Rektor kościoła Wawrzyniec Matecki. Wykaz książek liturgicznych i proboszcza, Organista Mateusz Dubielski, posiadający odpowiednie uposażenie. Dwaj Witrykusi, Maciej Chełkowski i Grzegorz Nowakowski. Trzy akuszerki odpowiednio poinstruowane, Szpital nowy, wystawiony staraniem proboszcza, bez funduszu specjalnego, z wyjątkiem sześciu florenów zapisanych przez wspomniana Czerwińską, s. 514,

Dekret reformacyjny z dnia 26 kwietnia 1766 r., s. 514-516.

L a 1 k o w y. Wieś królewska z kościołem murowanym, pod wezwaniem św. Barbary, konsekrowanym w 1409 roku. Prawo patronatu należało do monarchy. Opis świątyni, w której, w ołtarzu wielkim znajdował się obraz Matki Bożej uważany za łaskami słynący. Było bractwo św. Barbary z przywilejem odpustowym, z przywileju papieża Benedykta XIII z roku 1725, co potwierdził Konsystorz Gdański. Opis wnętrza świątyni i jej wyposażenia, s. 517-518.

Indeks rzeczy świętych, naczyń srebrnych liturgicznych i innych paramentów oraz sprzętów kościelnych. Dosyć dokładny spis książek w liczbie około czterdziestu. Opis stanu zewnętrznego świątyni, której ściana frontowa została odbudowana w 1741 r., gdzie nad wejściem zrobiono kaplicę służącą jednocześnie za bibliotekę. Dzwonnica murowana, Cmentarz został niedawno ogrodzony, a na nim kostnica przy murze kościelnym, s. 518-524.

Wsie parafialne: Lalkowy, Rynkówka, Fronca, Smętowo, Smentówko, Kopytkowo, Włosiennica, Udziesz oraz kolonie Bukowiny, Cysowy i Jesieniec. Wiernych do sp[owiedzi wielkanocnej było 749 osób. Ostanie misje przeprowadzili misjonarze z parafii Świety Wojciech w 1765 r., s. 524.

Opis stanu zabudowań plebańskich, tak mieszkalnych, jak i gospodarczych. Nazwiska mieszkańców korzystających z domów parafialnych, których było pięciu: Stanisław Filipowicz, Michał Kruczyński, Adam Malicki, Adam Wożnicki i Jakub Licowski. Według dawnego dokumentu parafia miała na uposażenie sześć łanów ziemi, ale aktualnie tylko cztery łany posiada. Ponadto dwa małe stawy. Zapis na lampę [zapewne przed Najświętszym Sakramentem] od Marianny z Wielowiejskich Ossolińskiej, zabezpieczony na mieście Gniew, z 1735 r., czego dokument znajdował się w aktach parafii. Proboszcz pobierał meszne, tu wymienione według wsi. Inwentarz gospodarczy, s. 524-526.

W ostatnim roku było 46 chrztów, 12 ślubów i 15 pogrzebów. W pałacu w Rynowach znajdowała się kaplica, posiadająca relikwie głowy św. Felicyta Męczennika. Był indult, wystawiony w warszawie 12 I $1765 \mathrm{r}$. przez ordynariusza miejscowego zezwalający na mszę dla miejscowych dziedziców, s. 526-527.

Rektor kościoła Franciszek Uzdowki, organista i nauczyciel szkoły Adam Witkowski, posiadający odpowiednie uposażenie. Trzej zaprzysiężeni Witrykusi: Jakub Firin, Józef Szczukowski i Marcin Faletowski. Akuszerki przygotowane. Przytułek zbudowany w 1729 r. przez parafię. Ubodzy żyją na proszonym chlebie, s. 527-528.

Dekret reformacyjny z dnia 19 kwietnia 1766 r., s. 528-530.

B a r ł o ż n o. Wieś królewska w starostwie osieckim. Kościół murowany pod 
wezwaniem św. Marcina. Prawa patronatu królewskiego. Opis świątyni, jej wnętrza i trzech ołtarzy. Był zapis na fundusz palącej się lampy przed Najświętszym Sakramentem zapisany na młynie Piła przez zmarłych Jakuba Feszter i Jakuba Hersztowskiego w 1727 r., co dawało rocznie 6 florenów, ale lampa nie stale się paliła, s. 531-532,

Inwentarz rzeczy świętych, a więc naczyń liturgicznych i innych paramentów oraz sprzętów kościelnych, w tym także tych, które sprawione zostały przez aktualnego proboszcza. Wykaz książek w liczbie około 23. Księgi metryk spisywano. Sposób sprawowania służby bożej. Pozostałe wyposażenie wnętrza świątyni oraz jej stan zewnętrzny. Dzwonnica murowana. Cmentarz z kostnica, dobrze ogrodzony, s. 532-539.

Uposażenie kościoła z jednego łana danego przez Jakuba Piąntek ${ }^{206}$, ale posiadany z nadania króla Władysława ${ }^{207}$, co inkorporował do parafii biskup [Mikołaj] Gniewosz z Oleksowa 20 maja 1652 r., Z czego parafia ma rocznie 30 florenów dochodu. Ponadto posiada cztery domy, z czego z trzech pobiera czynsz, a w czwartym mieszka nauczyciel, opiekujący się także zegarem. Na mieście Starogard był zapis 150 florenów, dający rocznie 9 florenów dochodu, s. 539-540.

Wsie parafialne: Barłożno, Mirotki, Lipiagóra, Gąsiorki, Kirwald, Piła. Ponadto folwarki Olszewice i Markocin. Spowiadających się na Wielkanoc było 751 osób. Ostatnie misje odbyły się w 1764 r. przeprowadzone przez reformatów, s. 540.

Opis zabudowań plebańskich, mieszkalnych i gospodarskich. Uczyniono tu uwagę, że do ich remontów i odbudowy zobowiązani byli parafianie. Na gruncie parafialnym i na proboszcza mieszkało siedmiu wieśniaków, którzy czasu żniw odpracowywali należność. Kościół miał cztery łany ziemi, jak to wykazał pomiar sporządzony przez zaprzysiężonego geometrę w $1759 \mathrm{r}$. Według dawnej wizytacji przeprowadzonej przez [Augustyna] Klińskiego ${ }^{208}$ były jeszcze cztery lany należące do parafii. Do proboszcza, z przywileju królewskiego z 1759 r. należała łąka Popówka zwana, przylegająca do granicy wsi Bukowiec. Lasów nie było, ale proboszcz posiadał prawo wolnego wyrębu drewna w lasach starostwa osieckiego. Ponadto były dwa stawy. Siedmiu wieśniaków, o których wyże, oddawało pewien czynsz. Dziesięcinę pieniężną pobierano z folwarków Olszewice i Markocin. Inwentarz gospodarski, żywy i martwy. Wykaz mesznego, s. 540-542.

W ostatnim roku było 16 ochrzczonych, pobłogosławiono 4 pary małżeńskie i pochowano 12 osób, mianowicie 3 mężczyzn, 3 kobiety, 4 młodzieńców i 2 dziewczyny. Luteran w całej parafii było 35, w tym mężczyzn 6 , kobiet 6 , chłopców 11 i dziewcząt 12, s. 542.

Rektorem kościoła był Andrzej Dobrowolski, kanonik kolegiaty Wszystkich Świętych w Krakowie, rezydujący stale w parafii. Organista Antoni Chmielecki, posiadający dostateczne uposażenie. W tym także wynagrodzenie od bractwa za śpiewanie różańca. Witrykusami zaprzysiężonymi byli: Bartłomiej Lelowski, Antoni Chmielecki organista, Józef Waskowski, Maciej Klejna i Bartłomiej Popkow-

${ }^{206}$ Tam zapisano to nazwisko.

${ }^{207}$ Pewnie chodzi o Władysława IV.

${ }^{208}$ Biogram tego archidiakona pomorskiego zob. C h o d y ń s k i, Katalog, s. 391-393. 
ski. Uczniów było niekiedy 8 chłopców oraz dziewcząt od 8 do 3. Akuszerki pouczone dostatecznie. W starym szpitalu trzy ubogie wdowy żyjące o proszonym chlebie, s. 542-543.

Dekret reformacyjny z dnia 28kwietnia 1766 r., s. 543-544.

Pło c h o c i n. Wieś dziedziczna Stanisława Jasińskiego, sędziego ziemskiego tczewskiego. Kościół w 1701 r, wystawiony z pruskiego muru przez Aleksandra Czapskiego, podkomorzego malborskiego i Franciszka Jasińskiego, sędziego ziemskiego puckiego, pod wezwaniem św. Wawrzyńca. Opis świątyni i jej wyposażenia, a więc ołtarzy. Obraz matki Bożej znajdujący się w świątyni uważany był za łaskami słynący, s. 545-546.

Inwentarz rzeczy świętych, paramentów liturgicznych srebrnych i innych oraz pozostałego sprzętu kościelnego, s. 546-548.

Był zapis na rzecz bractwa różańcowego, z darowizny Jasińskiego, sędziego puckiego, z czego proboszcz był zobowiązany do odprawiania mszy w wyznaczonych intencjach. Ponadto był zapis niejakiego Kazimierza Jordańskiego. Sposób sprawowania służby bożej. Metryki spisywano. Wykaz pozostałych sprzętów w kościele oraz opis stanu zewnętrznego kościoła. Dzwonnica z pruskiego muru, bardzo zniszczona. Cmentarz należycie ogrodzony, s. 548-549.

Utrzymanie kościoła należało do parafian i kolatora. Wsie parafialne: Płochocin, Płochocinem, Lipanki, Bękowo, osada młyńska Borowy i Bekowski, folwarki Huta Stara i Huta Nowa oraz Homer. Wiernych do spowiedzi na Wielkanoc było 330. Dom proboszcza nowy i zabudowania gospodarcze takież, wystawione przez aktualnego proboszcza, dom organisty stary. Na uposażenie były trzy łany ziemi, jeden poddany plącący 6 florenów i mający do odpracowania sześć dni roboczych podczas żniw. Opis tej ziemi i jej położenia. Dwie morgi łąk. Kolator Jasiński okazał wyciąg z akt grodu w Nowem, z którego wynika, że za Stanisława Karkowskiego, biskupa włocławskiego ${ }^{209}$, w 1577 r., parafia w Płochocinie posiadała jeszcze cztery łany położone w dobrach Warlubie. Proboszcz miał prawo wolnego wyrębu drewna oraz jezioro zwane Psino. Pobierał także meszne, tu dokładnie wyliczone. Inwentarz gospodarczy, żywy i martwy., s. 549-551.

W ostatnim roku było 24 ochrzczonych, 8 ślubów i 10 pogrzebów. Luteran w Płochocinie była jedna rodzina, a w innych wsiach 192 osoby, s. 551.

Rektorem kościoła był Michał Pączkowski. W parafii było bractwo różańcowe. Organista Tomasz Kitowski, należycie uposażony, co tu wyliczono. Witrykusi zaprzysiężeni Maciej Wąs i Wojciech Talitowski,. Akuszerki poinstruowane. Szpital stary w ruinie, gdzie przebywało 4 ubogich. W kościele był nowy organ siedmio głosowy i nowa ambona, s. 551-552.

Dekret reformacyjny z dnia27 maja 1766 r., s. 552-553.

K o m o r s k. Wieś biskupa włocławskiego. Kościół stary, drewniany z 1684 r., pod wezwaniem św. Bartłomieja, konsekrowany 19 sierpnia 1691 r. przez bis-

${ }^{209}$ Był biskupem włocławskim w latach 1567-1581. 
kupa włocławskiego Bonawenturę Madalińskiego ${ }^{210}$. Prawo patronatu należało do biskupa włocławskiego.Opis wnętrza świątyni i pięciu ołtarzy. Z zapisu biskupa włocławskiego ze wsi Kurzejewo dochód w sumie około 80 florenów szedł na lampę przed Najświętszym Sakramentem. Zakrystia drewniana, s. 554-555.

Inwentarzrzeczy świętych, srebrnych iinnych paramentów liturgicznych, w tym także tych, które należały do bractwa różańcowego. $\mathrm{Z}$ zapisu 700 florenów na mieście Nowe, proboszcz lub wikariusz mieli odprawiać msze za ofiarodawców, ale nie podano kto to był i za braci z bractwa różańcowego. Ponadto był drugi zapis uczyniony przez dawnego proboszcza, Andrzeja Robakowskiego ${ }^{211}$, kanonika kruszwickiego dla promotora bractwa św. Jana Nepomucena na sprawowanie dwóch mszy kwartalnie za fundatora i w intencji bractwa. $Z$ tych zapisów pewne część szła też na utrzymanie ubogich w przytułku. Sposób sprawowania nabożeństw. Wyposażenie świątyni w potrzebne sprzęty. Metryki spisywano. Opis stanu zewnętrznego świątyni.. Wieża, która była jednocześnie dzwonnica, murowana i jak powiadano pochodziła z czasów krzyżackich. Cmentarz ogrodzony, s. 555-559.

Dochód kościoła pochodził z samych akcydensów. Wsie parafialne: Komorsk, Wielki Komorsk, Mały Komorsk, Pastwisko, Kurzejewo, Piaski, Warlubi, Rolewo oraz folwarki Rólewko i Rozgarty. Wiernych spowiadających się na Wielkanoc było 824 osoby., s. 559.

Opis zabudowań plebańskich, proboszcza, wikariusza i organisty oraz zabudowań gospodarczych. Zabudowania w folwarku Kurzejewo w stanie złym. Na uposażenie były cztery łany i łąka zwana Londy. Wykaz płaconego mesznego. Niejaka Marianna Fudatowa zapisała 100 florenów na kościół i na bractwo różańcowe po 50 florenów, co dawny proboszcz Malecki umieścił na gospodarstwie niejakiego Szymona Smarsz i ten jest zobowiązany do restytucji. Inwentarz gospodarski, dokładnie sporządzony. Jeszcze raz powiedziano, że uposażenia proboszcza pochodzi z czterech łanów ziemi, łąki czynszów, mesznego i akcydensów, s. 559-562.

Przy koiciele była kaplica św. Michała. Ponadto na piętrze dworu Pawłowskiego w dobrach Rulewo była kaplica, gdzie na mocy indultu Stolicy Apostolskiej i za zgodą biskupa Czapskiego ${ }^{212}$ odprawiano mszę, ale z zachowaniem prawa parafialnego. Na terenie parafii, we wsi Piaski było 30 rodzin luterańskich, s. 562 .

Rektorem kościoła był Józef Moradowicz, kanonik lwowski, ale stale przebywający we Włocławku. Parafią zarządzał Jan Kręciszewski. Organista Maciej Krauza, którego uposażenie tu opisano. Zaprzysiężeni Witrykusi Szymon Wiśniewski, Jakub Gąsieniewski i mateusz Maciejewski. Uczniowie pobierali naukę jedynie w zimie. Akuszerki pouczone wystarczająco. Przytułek nowo wystawiony, ale jeszcze nie w pełni ukończony, a w nim 6 podopiecznych, którzy mieli na

\footnotetext{
${ }^{210}$ Był biskupem w latach 1681-1691.

${ }^{211}$ Krótki biogram tego kanonika kruszwickiego zob. F i u t a k, Prałaci, s. 98.

${ }^{212}$ Walenty Aleksander Czapski był biskupem włocławskim w latach 1741-1751.
} 
uposażenie 18 florenów z wyżej podanych zapisów na bractwa, a także ogród leżący przy nim, s. 562-563.

Dekret reformacyjny z dnia 28 maja 1766 r., s. 563-564.

L u b i e ń. Wieś królewska w starostwie grudziądzkim. Kościół parafialny murowany, z czasów krzyżackich, pod wezwaniem św. Jakuba Większego, patronatu monarszego. Opis świątyni i jej wnętrza z trzema ołtarzami. Lampa przed Najświętszym Sakramentem paliła się jedynie podczas nabożeństw. Zakrystia murowana. Nowe organy siedmio głosowe, s. 565-566.

Inwentarz rzeczy świętych, naczyń srebrnych i innych paramentów liturgicznych Sposób sprawowania służby bożej. Inne sprzęty kościelne. Metryki spisywano. Opis stanu zewnętrznego świątyni. Dzwonnica, stojąca osobno, drewniana. Cmentarz ogrodzony, s. 566-568.

Do utrzymania kościoła byli zobowiązani parafianie, bo taki był zwyczaj i ziemi pruskiej i takie polecenie króla Władysława IV z 11 czerwca 1640 r., wystawionego $\mathrm{w}$ Warszawie, przypominającego o tym obowiązku sołtysom wsi parafii Lubień. Odpis tego dokumentu wzięty z akt kapituły włocławskiej. Z tego dokumenty dowiadujemy się, że przez 40 lat nie było tam proboszcza., s. 568-569. Przytoczono też dokument wprowadzający w życie owo postanowienie królewskie, wystawiony prze biskupa Macieja Łubieńskiego, z dnia 16 października 1640 r. Obydwa dokumenty wyjęte z akt kapituły włocławskiej i akt Konsystorza Włocławskiego i potwierdzone pieczęcią biskupa Czapskiego. Powyższe odpisy znajdowały się w parafii. Ponadto zarządzenie Augusta Czarneckiego, komisarza, wystawione w zajączkowi 15 grudnia 1730 r. i drugie, z marca 1733 r., wystawione przezn niepodanego imienia Potocką, zapewne dzierżawczynię Lubienia, żeby mieszkańcy, także innowiercy, spełnili swoje zobowiązania wobec parafii w Lubieniu i wobec proboszcza, kanclerza wrocławskiego i plebana z Lubienia, s. 568-574 .

Wsie parafialne: Lubień Wielki, Lubien Mały, Tragasz, Zajączkowo Wielkie, Zajączkowo Małe, Montawy. Wiernych, spowiadających się na Wielkanoc było 185 osób. Nie pamiętano, kiedy odbyły się tu ostanie misje, s. 575.

Zabudowania plebańskie w Ruinie i aktualnie mieszkał w nich organista. natomiast rektor kościoła zamieszkiwał $\mathrm{w}$ domu wystawionym przez dzierżawcę. Opis pozostałych zabudowań. Parafa posiadała cztery łany ziemi z łąkami. Wykaz mesznego, w tym także pobieranego od menonitów, ale nie wszyscy innowiercy je oddawali. Powrórzono ogólnie, że dochód proboszcza składał się z czterech łanów ziemi, mesznego, niewielkich czynszów i akcydensów, s. 575-577.

W ostatnim roku było 80 chrztów, pobłogosławiono jedno małżeństwo i pochowano 10 osób. Ogólnie było 80 mężczyzn, i 88 kobiet. Na terenie parafii mieszkało 70 luteran i około 1000 menonitów, s. 577.

Rektorem kościoła był Antoni Raba, posiadający także beneficjum parafii Bzowo oraz spełniający obowiązki spowiednika w klasztorze sióstr w Grudziądzu. Wikariusz Krzysztof Langkau. Organista Jan Jorkowski, s. 577.

B z o w o. Kościół filialny, stary. Dawniej była to filia parafii w Komorsku, ale 
ostatnio, z polecenia ordynariusza miejscowego dana w zarząd księdzu Antoniemu Raba, dziekanowi, który został zobowiązany do rozebrania starego kościoła i postawienia nowego. Aktualnie zostały już położone fundamenty pod nowa świątynię. Nie podano wezwania przyszłej świątyni, s. 578.

Wykaz sprzętów kościoła w Bzowie, naczyń liturgicznych srebrnych i innych paramentów. Podano ty, że kościół stary był pod wezwaniem św. Małgorzaty. Opis starej świątyni, już nieistniejącej. Metryki spisywano. W domu rektora, starym, mieszkał dzierżawca. Inne zabudowania plebańskie zniszczone. Na uposażenie były cztery łany ziemi, ale aktualnie powierzchnia ta się zmniejszyła. Mówiono, że dawniej do parafii należało jezioro Głowinek z lasem, co zanotowano w wizytacji z czasów biskupa Rozdrażewskiego, s. 578-579.

Wsie parafialne: Bzowo, Osiek, Krusze, Fletowo, Bzowo, Grupa Wysoka, Grupa Niska, folwark Kompania i młyn Piła. Wykaz pobieranego mesznego, ale niektóre wioski tego świadczenia nie oddawały. Liczni byli luteranie i menonici. Był nauczyciel uczacy dzieci. Akuszerki wystarczająco pouczone. Przytułek stary, s. 579.

Dekret reformacyjny dla obydwóch kościołów, z dnia 31 maja 1766 r.

P i e n i a ż k o w o. Wieś biskupa włocławskiego. Świątynia murowana, pod wezwaniem św. Jana Chrzciciela, wzniesiona staraniem biskupa Rozrażewskiego w 1594 r. Przytoczono tu dosłownie zapis tego wydarzenia, wzięty z akt tegoż biskupa $^{213}$. Prawo patronatu należało do biskupa włocławskiego Opis wnętrza świątyni z trzema ołtarzami. Przed Najświętszym Sakramentem lampa paliła się jedynie podczas nabożeństw, s. 582-583.

Inwentarz rzeczy świętych, naczyń srebrnych liturgicznych, pozostałych paramentów liturgicznych i innych rzeczy kościelnych, Sposób sprawowania służby bożej. Metryki spisywano. Pozostałe wyposażenie kościoła i jego stan zewnętrzny. Cmentarz otoczony murem, s. 583-585.

Utrzymanie świątyni należało do parafian. Wsie parafialne: Pieniążkowo, Luchowo, Czerwińsk, Ostrowite, Kolimaga, Smarżewo, Półwsie, Dabrówka, Wiosło, Murowana karczma oraz Trzy Młyny ${ }^{214}$. Wiernych spowiadających się na Wielkanoc było 535 osób. Nie pamiętano, kiedy były ostatnie misje, ale spodziewano się, że odbędą się w roku przyszłym, s. 586.

Opis zabudowane plebańskich, drewnianych. Organista mieszkał s starym domu. Inne zabudowania plebańskie. Uposażenie stanowiły ogrody, cztery łany ziemi, ale część tego przywłaszczyli sobie wieśniacy Pieniążkowi, gdy tu nie było proboszcza, łąki, z których jedna została dana parafii przez nieżyjącego już, niepodanego imienia, Szliben i położona była przy granicy z Lalkowami. Wykaz pobieranego mesznego. Prawo wolnego wyręby drewna w lesie ostrowickim. Inwentarz gospodarczy, dokładnie sporządzony, s. 586-588.

W ostatnim roku ochrzczono 43 dzieci, pobłogosławiono7 3 małżeństwa i pochowano 25 osób. Luteran było na terenie parafii 41 osób, s. 588.

\footnotetext{
${ }^{213}$ Podano nawet dokładnie: tom 4, karta 269.

${ }^{214}$ Czy taka nazwa, czy też trzy osady młyńskie?
} 
Rektorem był Paweł Osieński. Jednocześnie był też promotorem bractwa Aniołów Stróżów, zaprowadzonego w 1642 r. Organista Antoni Lubowski, dobrze uposażony, który uczył także dzieci, ale jedynie w okresie zimowym. Byli trzej Witrykusi, ale nazwisk nie podano, s. 588.

Kaplica prywatna we dworze dóbr Ostrowite, które znajdowały się w posiadaniu Dąmbskiego, wojewody brzesko-kujawskiego, z prawem sprawowania tu mszy z zezwolenia oficjała gdańskiego. Ponadto w lesie ostrowickim kaplica także z zezwoleniem na nabożeństwa przez tego oficjała. Akuszerki były pouczone o swojej powinności. Przytułek wystarczający, ale ubodzy żyli z jałmużny. Mieli także ogród dany im przez obecnego proboszcza, s. 589.

Dekret reformacyjny z dnia 26 maja 1766 r., s. 589.

Osobisty podpis Bartłomieja Trochowskiego, kanonika kruszwickiego, prepozyta ze Świecia, przeprowadzającego niniejsza wizytacje i jego pieczęć wyciśnięta w czerwonym laku, s. 589.

Indeks miejscowości parafialnych, sporządzony inną ręką, ale sporządzony według dawnej paginacji 


\section{DAS REPERTORIUM DER IM DIÖZESANMUSEUM IN PELPLIN AUFBEWAHRTEN VISITATIONSBÜCHER DER BISCHÖFE VON KUJAWIEN UND POMMERN. TEIL II}

\section{Zusammenfassung}

Das hier präsentierte Repertorium bildet den zweiten Teil des "Repertoriums der im Diözesanarchiv in Pelplin aufbewahrten Visitationsbücher der Bischöfe von KujawienPommern". Der erste Teil wurde veröffentlicht in "Archiwa, Biblioteki i Muzea Kościelne" 84 (2005), S. 93-236.

Im zweiten Teil werden vier Bücher besprochen, die die Signaturen G 26, G 40, G 56 und G 61 tragen.

Das Buch G 26 betrifft die von Archidiakon Jan Kazimierz Jugowski in den Jahren 1710-1711 in der Amtszeit von Bischof Konstanty Felicjan Szaniawski durchgeführten kanonischen Visitationen des Archidiakonats Pommern. Es enthält die Protokolle der Pfarrvisitationen in den Dekanaten: Bern (Kościerzyna), Puck, Bytów, Lębork, Starogard, Gdańsk, Tczew, Nowe Miasto, Gniew und Świecie.

Das Buch G 40 betrifft die im Jahre 1728 von Archidiakon Józef Ignacy Narzyński durchgeführte Generalvisitation des Archidiakonats Pommern. Dieses Buch enthält die Visitationsprotokolle der Pfarreien des Dekanats Mirachowo, die nach der Visitation erlassenen Reformationsdekrete der Dekanate, Schilderungen der Pfarreien Tczew und Lubiszewo sowie von 37 anderen Pfarreien ohne Einteilung in Dekanate und ohne Angabe der Visitationsdaten.

Das Buch G 56 betrifft die von Archidiakon Augustyn Kiliński im Jahre 1746 durchgeführte Visitation des Archidiakonats Pommern. Es umfaßt die Dekanate Tczew, Gniew, Nowe Miasto und Świecie.

Das Buch G 61 betrifft die von Bartłomej Franciszek Ksawery Trochowski in der Amtszeit des Bischofs von Włocławek und Pommern Antoni Kazimierz Ostrowski in den Jahren 1765-1766 durchgeführten Visitation dreier Dekanate: Gdańsk, Starogard und Tczew im Archidiakonat Pommern.

Włodzimierz Bielak

Aus dem Polnischen übersetzt von Herbert Ulrich 